\title{
PALACES
}

\section{OF CRETE}

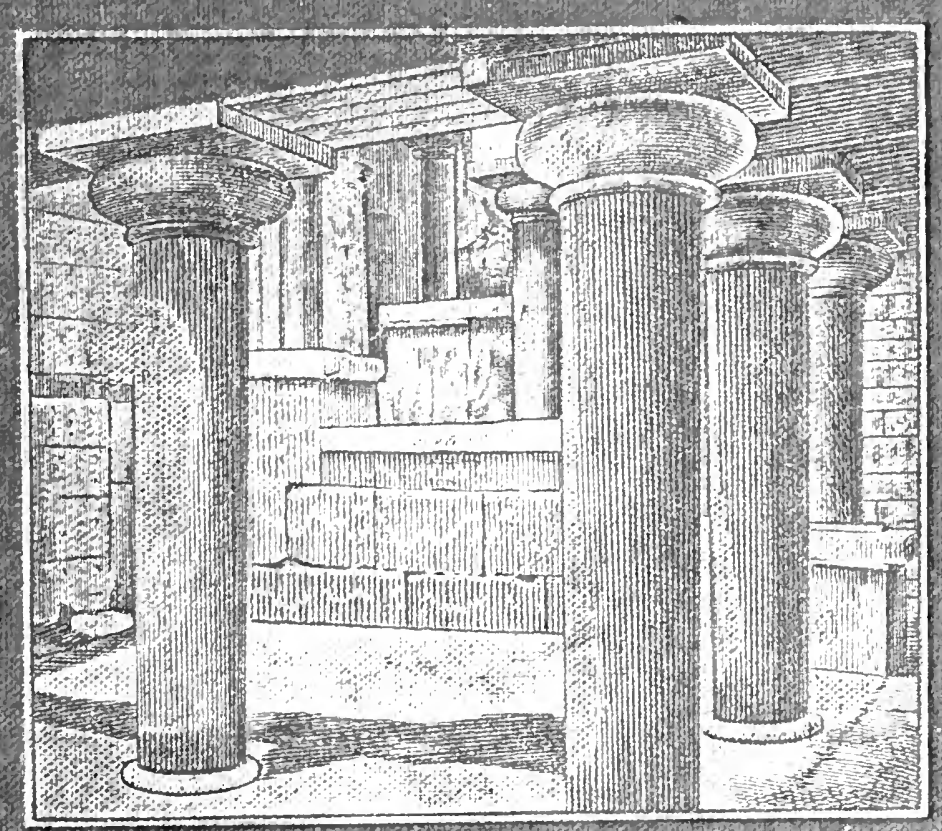

\section{ANCRLO MOS8O}


$\Delta$ 


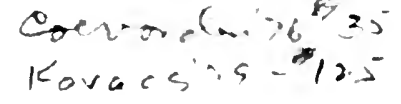





\section{THE PAIACES OF CRE'TE AND THEIR BUILDERS}




\section{WORKS ON GREEK HISTORY}

THE SILVER AGE OF THE GREEK WORLD. By J. P. Mahaffy, D.D., sometime Professor of Ancient History in the University of Dublin. Large crown 8 vo, cloth, i 3 s. 6 d. net.

THE PROGRESS OF HELLENISM IN ALEXANDER'S EMPIRE. By J. P. MAHAFFY, D.D. Large crown 8 vo, cloth, 5s. net.

ALEXANDER'S EMPIRE. By J. P. MahafFy, D.D. With 43 Illustrations and Maps. Eighth Impression. Large crown 8vo, cloth, js. ("Story of the Nations").

THE STORY OF GREECE, FROM THE COMING OF THE HELLENES TO A.D. I4. By E. S. Shuсквurgh, sometime Fellow of Emmanuel College, Cambridge. With 2 Maps and about 70 Illustrations. Large crown 8vo, cloth, 5s. ("Story of the Nations").

LONDON: T. FISHER UNWIN. 



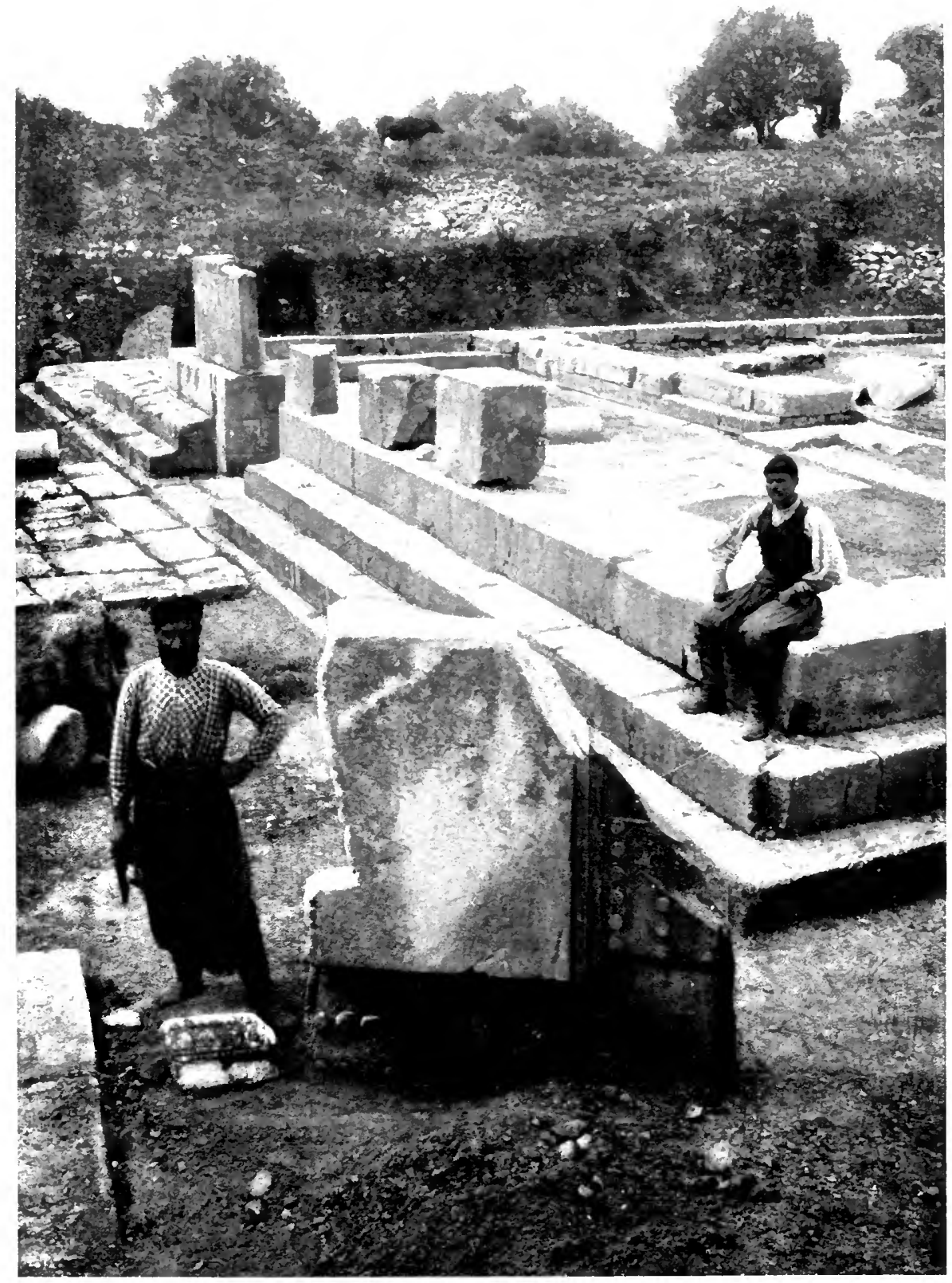

THE TE.IPLE OF APOLLO. 
AUTHOR OF "THE LIFE OF MAN ON THE HIGH ALPS," ETC.

I L.LCSTRATED

LONDON

ADELPHI TERRACE

MCMIVII 
(All rights reserede) 
$\Gamma_{0}$

I)R. HAZZIIAKI

FPHOR OF CRETAN ANTIQUTTIFS 



\section{PREFACE}

THE information that we have as to the Italians of pre1 historic times is scanty and full of contradictions, and, after a study of the most ancient skulls of Etruria and of the Roman Forum, I decided to extend my anthropological researches to the island of Crete, as the ages of stone and of bronze can be studied there more thoroughly than in Italy. In my expeditions on the Mediterranean I collected the material for the following works :

Neolithic Civilisation in Crete.

Skulls and Skeletons of the Bronze Age in Crete.

Chemical analysis and chronological comparison of the most ancient weapons of copper and bronze of the countries on the Mediterranean.

If these three studies were printed for learned societies they would be lost to the general public for whose benefit I have for many years published my work. Moreover, I desire to collect my impressions of travel, and must explain how it is that I have become an amateur archæologist. The teaching in our schools as regards the civilisation of the pre-Hellenic world before the time of Homer is so little in accordance with the results of the most recent archæological discoveries, that students of art and letters will, l think, be glad to have some account of the monuments, which show the need for considerable modifications 
in the teaching relating to prehistoric civilisation. In order to enable my readers to verify or criticise my statements, I publish a number of original photographs and others for which I have to thank Mr. Arthur Evans, Professor Frederic Halbherr, and Dr. Luigi Pernier, who have kindly allowed me to use many illustrations published in their recent works. The philologists imagined the Aryan people and the theory of the Indo-Germans, and many persons still believe in this theory. I hope to convince the reader that primitive Mediterranean civilisation did not originate with the Indo-Germans, and I advise him to begin with the last chapter that he may see at once the conclusions to which I have come. If, however, he has faith and patience it will be better for him to follow the order in which I have arranged the evidence and related my impressions of travel.

1906. 


\section{CONTENTS}

PREFACE.

CHAP'TER I

THE FXCAVATIONS .

The Neolithic period at Phæstos-Great antiquity of PhæstosMagnetic stone in Neolithic soil-Ruins of an archaic Greek building - Cellar of an ancient Greek house-Discoveries made by Dr. Pernier at Phastos in 1906-Kamares vases.

\section{CHAPTER II}

THE PALACE, OF PHÆS'TOS

The great flights of steps in Minoan architecture-Magazines with large Kamares vases-Technique of the pottery-The palaces of Homer-Origins of Greek architecture-Description of an apartment-A private chapel or shrine-The inevitable destruction of Mycenzan ruins.

\section{CHAP'TER 1 II}

\section{A MYCENAAN VILLA}

Bronze statuette of the Minoan period-1nvention of writing-Seals from Hagia Triada - The chicftain vase, discovered by Professor Halbherr-Interior of a room-Magnificence of Mycenæan apartments-Church of S. George-Mycenxan necklaces and pendants'The ruins and the landscape. 


\section{CHAPTER IV}

THE RUINS OF GORTYNA . .

The heiress-Roman statues in a trench-The Temple of ApolloThe Emperor Mareus Aurelius-The house of Manoli.

\section{CHAPTER V}

IHE PALACE OF KNOSSOS

Pipes for the drinking-water supply-Plan of the most ancient cities - Throne of Minos-Grand staircase in the palace of KnossosDouble walls - Chronological classification according to Arthur Evans.

\section{CHAPTER VI}

WOMEN'S DRESS

Female types in the miniatures-A priestess-Saffron yellow--The women's workroom-Purple dye.

\section{CHAPTER VII}

THE CRAF'TSMEN OF MINOS.

A carpenter of Knossos-The houses of Knossos-Early hutsKitchen pots and floor of huts-Domestic utensils-Workmen's writing-Bronze tools for different crafts.

\section{CHAPTER VIII}

\section{PREHISTORIC SOCIALISM}

A prehistoric revolution-Beginnings of the Mediterranean civilisation-Steatite vase published by Savignoni-A rebus to guess.

\section{CHAPTER IX}

\section{MYCEN蚱}

The Lion Gate-Cretan sculpture at Mycena-Pre-Mycenæan pottery-Mycenzan civilisation not derived from the AchaansTreasures found in the tombs-Decadence of Mycenæan art. 


\section{CHAPTER X}

Worship of stones in Rome and Italy-Temples for the adoration of pillars-Procession in front of a temple-Sacred trees-Cretan superstitions about trees-The time before Zeus-Relations of Crete with Latin civilisation-Religious decadence in the epic of HomerThe monastery on the hill of Phestos.

\section{CHAP'TER XI}

BULL-GRAPPLING

The conical vase of Hagia Triada-Giant bulls of the Myceniean period-Fresco of Knossos discovered by Dr. Evans-Bull-grappling fresco from Tiryns-Ivory statuette found by Dr. Evans-Wrong interpretation of the V'aphio cup.

\section{CHAPTER XII}

FOOTGEAR IN THE TIME OF MINOS

Varieties of boots and shoes in Crete-Puttees-Gaiters of the Mycenzan soldiers-Stele-Sandals and shoes-Heeled shoesPavements of Knossos-Mud floors in Homer-Tomb of Rekhmara - Men from beyond the sea.

\section{CHAPTER XIII}

SCULPTURE AND PAINTING .

Study of nature--Figurines of animals in terracota-Masterpieces of ceramic art-Representations of the cow and the goat-The life of the sea-The painter's palette-Perception of colours-Decadence ot art.

\section{CHAPTER XIV}

Origins of the worship of female deities in Crete-Sacred images discovered by Dr. Evans-Grotto of Eileithyia-Primitive Cretans in Sicily-Matriarchal society-Doves-Cretan pillars and the Lion Gate of Mycenx-The worship of Venus not derived from the Phonicians. 


\title{
CHAP'TER XV
}

COOKING IN POETRY AND IN REAL LIFE •

How the epic material was worked up-Omissions in the Homeric poems-Millstones-Models of Minoan saucepans-Dr. Pernier's discovery of the most ancient known fiteplace-Bronze utensilsVessels for sifting and filtering-Olive oil-Tall lamps-The cradle of Mediteranean civilisation - The Doric invasion, and recent discoveries.

\section{CHAPTER XVI}

IHHE THEATRE AND MUSIC

Structure of the earliest theatres-Dancing-The lyre and the flute -The chorus.

\section{CHAPTER XVII}

\author{
MEDITERRANEAN CIVILISATION NOT DERIVED FROM THE INDO- \\ GERMAN RACE . . . . . . . . 324 \\ Aryan languages-Sanscrit not as ancient as was supposed-Research \\ has failed to find the cradle of the Aryan race-My anthropological \\ researches-Tombs of Mycenaan style in Sicily-Physical education \\ in Mycenaan times-Relation between the diffusion of plants and of \\ human races.
}




\section{ILLUSTRATIONS}

Temple of Apollo . . . . . . . Frontispiect

I(i.

I. Hills of Phastos from the Plain . . . . . 17

2. Ruins of the two Palaces of Phæstos and theatral area . . 20

$P$ marks the place where I began to excavate.

3. Chambers of the Magazines where I excavated down to the virgin soil 21

The pit (Fig. +) was sunk in room $P$ in the left-hand comer.

t. Pit $5 \frac{1}{4}$ metres in depth below the level of the floor of the room marked P in Fig. 3 . . . . . . 23

5. Palace of Phæstos and Central Court from the south . . 27

6. Piece of Magnetite found, at a depth of + metres, in the pit (Fig. + ) near a temale idol of terracotta. . . . . . 29

7. Wall of an Archaic Greek edifice in the valley of S. Paolo below

Phastos . . . . . . . . 31

8. Bottom of a Trench. Amphorx, Hydrix, Cups and Tiles found in

the cellar of a Greek house . . . . . . $\quad 33$

9a. Hydria found in the trench (Fig. 8) . . . . . . .

96. Hydria found in the trench (Fig. 8) . . . . . 35

10. Excavations made at the foot of the great flight of steps in the Palace of Phastos by Dr. Pernier in 1906 . . . . 3i

11. Excavated room with Kamares vases in situ . . . . 39

12n. Kamares jug, Palace of Phrestos, Excavations of 1905 . . + t2

126. \& c. Kamares cups, Palace of Phæstos, 1906 . . . + +3

13. Kamares jug and cup, Palace of Phastos, 1906 . . . t+

1+. Ruins of the Palace of Phastos . . . . . . . $t^{6}$

1 5. Great Flight of Steps, Palace of Phastos . . . . . . + t9

16. Vestibule and Reception Hall in the Palace of Phastos . . 5I

1-. Excavation beneath the Vestibule of the Second Palace . . 53

Section corresponding to the three columns on the right in Fig. I 6 showing the vases as discovered in the magaines of the primitive palace. 
FI i.

18. Kamares vase found in the magazines of the earliest Palace of Phastos . 55

19. Kamares vase found in the magazines of the earliest Palace of Phastos . 57

20. Kitmares vase found in the earliest Palace of Phæstos . . . 57

21. Corridor of the Food Magazines . $\quad . \quad$. $\quad . \quad 59$

22. Masons' marks on the blocks of the Palace of Phæstos . . 62

23. A private apartment in the Palace of Phrstos . . . 63

24. Staircase leading from the upper floor to the private apartments . 65 Room to the left marked SALA on the plan.

25. Sanctuary in the Palace of Phæstos . . . . . . 67

26. Bronze Statuette of a woman found in the villa of Hagia Triada . 69

27. Flight of steps of the villa of Hagia Triada . . . . . 70

28a. Inscribed terracotta tablet found in the villa of Hagia Triada . 7 I

286. Inscribed terracotta tablet found in the Palace of Phrstos . . 72

$29 a \& b$. Inscribed tablets with writing found in the villa of Hagia Triada 73

$30 a \& b$. Seals. . . . . . . . . 74

$3 \mathrm{I} a \& b$. Seals . . . . . . . . . . . . .

$32 a \& b$. Seals . . . . . . . . . . . . . 76

33. Vase discovered at Hagia Triada by Prof. F. Halbherr . . 77

34. Vase discovered at Hagia Triada by Prof. F. Halbherr . . 78

35. Window and seats with alabaster blocks near the staircase in the villa

of Hagia Triada $\quad$. $\quad$. $\quad$. $\quad . \quad$. 8 I

36. Room with seats round, and three stone lamps left in situ . $\quad$. 82

Entrance of sleeping-room on the left. In front pieces of alabaster which formed the bases of the door-posts, formerly closed by wooden doors.

37. Church of S. George in the villa of Hagia Triada . . . 84

38. Belvedere in the villa of Hagia Triada . . . . 85

39. Fresco in the villa of Hagia Triada . . . . . 87

40. Gold pendant found in the villa of Hagia Triada . . $\quad$. 88

Drawn five times larger than the original.

4I. Kamares vase found in the most ancient Palace at Phæstos . $\quad 89$

42. The Laws of Gortyna . . . . . . . 93

+3. Byzantine Church of S. Titus near the theatre, where the blocks are

on which the Laws of Gortyna were inscribed . . . 95

In the foreground R. Lethœus.

44. The Apollo of Gortyna . . . . . . . 99

45. A trench made by Prof. Halbherr in the excavations of Gortyna . IOI

46. Tablet in honour of Marcus Aurelius and Lucius Verus . . 105

47. Roman baths, Gortyna . . . . . . 107

48. Manoli Iliaki, the guide of Gortyna, and his house . . . Io9 
Fis;

49. Kamares vase found in the most ancient Palace of Phastos.

50. Mycenaan pipe of terracotta for the supply of drinking water

51. Northern entrance of the Palace of Knossos.

52. Northern entrance of the Palace of Knossos, scen from above near the court

53. Throne of Minos

5+. Entrance to the ground floor by the staircase of the Palace of Knossos 122

55. Magazines of Knossos . . . . . 124

56. Double walls built of large blocks connected by wooden struts . 127

57. Dividing walls of the cells in the magazines of the Palace of Knossos I 29

58. Kamares vase found in the first Palace of Phastos. . . I3 I

59. Fresco from Knossos . . . . . . . 134

60. Porcelain Statuette of a Priestess found at Knossos by Dr. Evans . I 37

61. Skirt of an ex-voto dress from a sanctuary at Knossos . . I 39

62. Fresco from Hagia Triada representing a woman with parti-coloured and embroidered drawers . . . . . . . I

63. Woman's seat and work-table . . . . . . 1 .

64. Vase with design representing a net with shells of the molluse, from which the purple dye was obtained . . . . I 43

65. Libation table of steatite found at Phæstos . . . . It+

66. Bronze tools found in the tomb of a carpenter at Knossos . . 146

67. Furnace for pottery, Phrestos . . . . . 147

68. Large amphora of terracotta found at Phastos . . . Its

69. Terracotta model of a hut found at Phæstos . . . 1;0

70. Terracotta cooking pot holding fourteen litres . . . I 52

7I. Terracotta beehive (upside down), and large jar found at Phrstos . I 54

72. Piece of a terracotta vase, with inscribed signs, found at Phrstos . I55

73. Bronze key of the Mycenæan period . . . 157

74. Bronze utensil of the Mycenxan period, still used by the braziers

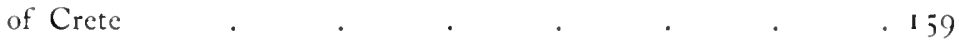

75. Vase from Hagia Triada, described by Savignoni . . . 167

$76 a$. Vase from Hagia Triada, described by Savignoni . . . 168

766. Vase from Hagia Triada, described by Savignoni . . . 169

77. Painted jug in late pre-Mycenxan style, found at Phxstos . . 172

78. Tomb of Clytemnestra at Mycenæ. . . . . I7t

79. The Lion Gate of Mycenx . . . . . 177

80. Frieze carved in red limestone. Knossos . . . . . 179

$81 a \& b$. Cretan vases in Mycenæan style . . . . 180 
82. Vase in Mycenæan style found in the tomb of Isopata at Knossos . I 1

83. Vase in pre-Mycenæan style found in the villa of Hagia Triada . I $s_{3}$

8. Stone idols found in a sanctuary at Knossos by Dr. Evans . . I 9 I

85. Fresco representing a temple for pillar worship, Knossos . . I 94

86. Procession before a temple, Knossos . . . . 195

87. Bronze figure of a calf found in the villa of Hagia Triada . . Ig6

$88 a \& 6$. Gold ring, with design of a sacred tree and a bretyl, found at Phæstos . . . . . . . . . . . . .

89a. Mould for casting rotive axes in bronze . . . . 198

896. Mould for casting in bronze the figure of a woman holding two axes. 199

90. Mount Joukta from Knossos . . . . . . 205

91. Monastery of S. George on the hill of Phæstos . . . 208

92. Tombs of the Monks of S. George . . . . 209

93. Steatite vase found at Hagia 'lriada . . 212

94. Detail ( $\frac{1}{3}$ less than the actual size) of the bull-grappling scene on the vase from Hagia Triada. . . . . . . 213

95a. Bull-grappling on the seal of a bracelet, found by Dr. Evans. $\quad 214$

956. Bull-grappling on the intaglio of a ring in the Museum at Athens . 215

96. Seal from Hagia Triada, enlarged . . . . . 2 I 6

97. Seal from Mycenx in the Museum at Athens . . . 217

98. Seal found at Præsos by Mr. Bosanquet, in the Museum at Candia 2 I 8

99. Head of a great bull which formed the spout of a terracotta vase found at Koumasa

1co. Fresco from Tiryns in the Museum at Athens . . . 220

IOI. Fragment in stucco found at Knossos by Dr. Evans. . . 22 I

Probably part of a taurokathapsia.

102. Ivory figure found at Knossos by Dr. Evans . . . 222

$103 a \& b$. Gold cup from Vaphio in the Museum at Athens . . 223

$10+a \& b$. Gold cup from Vaphio in the Museum at Athens . . $22+$

10fc. Detail of the Vaphio cup, two-thirds of the actual size . . 225

105. Footgear of an officer . . . . . . . . 227

106. Shoes and gaiters of a gymnast . . . . . . 227

107. Boots of a soldier. . . . . . . . . . 228

108. Terracotta statuette found at Petsofà, near Palaikastro, by Mr. Dawkins . . . . . . . . . 229

109. Fragment of a vase found at Mycenæ by Schliemann (about one-third of the actual size) . . . . . . . . . . 231

I IO. Terracotta shoe found at Sitia by the English School . . 233 
11:

1 I. Stele of Figeso, wife of Proxenos, in the Museum at Athens.

I12. Scal from Mycenx, magnified $3 \frac{1}{2}$ times

. 237

113. Footgear of a gymnast on a cup from Vaphio

. $23^{8}$

II V. Victory of the Acropolis of Athens unlacing her sandal

. $2+1$

1 15. Leg of an ivory statuette found at Knossos by Dr. Evans

- 245

116. Gold heart-shaped pendant found at Knossos by Dr. Fivans.

I 7 - a. lvory seal found at Hagia 'Triada.

I $1,-b, c, d$. Three faces of the ivory cube used as a seal.

. 250

118. Cretan wild goat, terracotta, found at /akros

. 251

I I9. Terracotta tablet, with Minoan writing and figures.

. 252

120. Bull from Gournia, terracotta, found by Miss Boyd

121. Knossos pottery

.256

122. Shells and fish in porcelain, made in moulds

. 257

123. Seal, representing a wounded lion, magnified 3 , in the Muscum at Candia .

124. Sea swallow caught near Candia

125. Vase for pouring wine in the sacrifices, decorated with nautilus, coral, and seaweed

126. Polypus designed in the best period of Minoan art . . 264

127. Polypus designed in the latest Mycenean period . . . 265

128. Sacrificial vase found at Phastos by Dr. Pernicr . . . 266

12.9. Head of an ox, style of the decadence in Mycenaan art . 267

30. Terracotta animals of the period of decadence in Mycenaan art .268

131. Female idol found at Phrestos in Neolithic soil near a magnetic stone 270

132. Objects found in a tomb of the first Minoan period, at Koumasa,

by Dr. Xanthoudides

Female image in marble, weapons in bronze and silver, vases in stone and terracotta.

133. Figures of women with doves stamped out of gold leaf, found at Mycenx by Schliemann . . . . . . 273

134. The Serpent Goddess, so named by Arthur Evans . . . $27+$

1 35. Marbie cross found amongst cultus objects at Knossos by Dr. Evans . 277

136. Terracotta group found at Palaikastro by Mr. Dawkins . . 283

137. Terracotta found at Knossos by Dr. Evans . • . . 285

Three columns similar to those of the Lion Gate of Mycenæ. A dove is perched on each capital.

138. Seal in the Museum at Candia

139. Fireplace found in the most ancient palace at Phestos by Dr. Peruice 294

I 4 . Large earthen cooking pot in the Museum at Candia . . 295 
14. Stewpan with condensing lid

$1+2 a, b, c, d$. Lid of a stewpan seen from above, below, and in section . 297

143. Copper lebes or cauldron in the Museum at Candia . . 298

$1+4$. Bronze ressels found in a tomb at Knossos by Dr. Evans . . 299

145 . Terracotta shovel for carrying lighted charcoal . . . 300

1456 . Charcoal shovel of more complicated shape . . . 300

146. Large terracotta vessel found by Mr. Dawkins . . . 301

1.17. Terracotta lamps . . . . . . . . . 302

148. Steatite lamps (larger and heavier than the last) . . . 303

1 49. Lamp of Spartan limestone found at Palaikastro . . . 304

$150 a, b$. Large lamps holding above a litre of oil . . . . . . 305

151. Terracotta candlestick, with socket for the candle, found at

Knossos by Dr. Erans . . . . . . . 306

152. Pre-Mycenæan painted jug found at Phæstos . . . 307

153. Theatre, Phæstos, discovered by the Italian Archæological Mission . 3 I I

154. Theatre, Knossos, discovered by Arthur Erans . . . 315

155. Fresco, Knossos, discovered by Dr. Evans . . . . . 317

156. Man playing a lyre . . . . . . . . . . . . . 8

Painting on a sarcophagus at Hagia Triada, discovered by the Italian Mission.

157. Man playing a double flute

Painting on a sarcophagus at Hagia Triada, discovered by the Italian Mission.

158. Larnax containing a skeleton, discovered by the Ephor Xanthoudides at Artsa

159. Larnakes found in the Necropolis of Phæstos by Prof. Savignoni . 337

160. Boxer with the cestus on the rlyton from Hagia Triada . . 341

Plates I. \& II.-Plan of the Palace of KNossos Facing pages I1 3, 114 


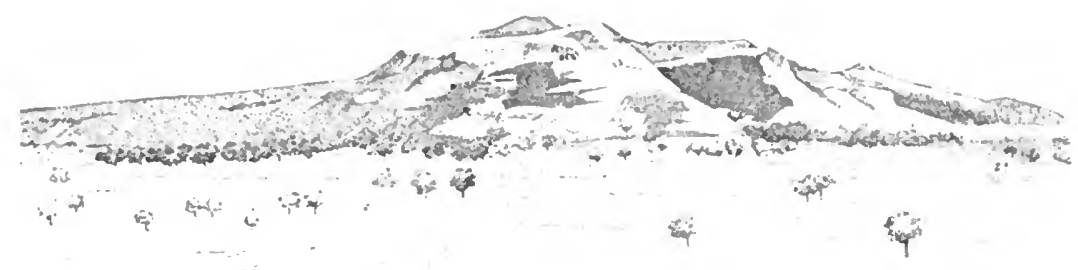

F1G, I.-HILLS OF PHASTOS FROM THE PLAN.

\section{THE PALACES OF CRETE AND THEIR BUILDERS}

\section{CHAPTER I}

THE EXCAVATIONS

I.

T WAS studying Etruscan skulls and the skulls discovered in the Roman Forum when I made the acquaintance of $\mathrm{Mr}$. Duncan Mackenzie, who was returning from Crete after helping Mr. Arthur Evans in the Excavation of Knossos. He told me of a cutting upon a hill where it had been possible to study the habitation of man as far back as twelve thousand years r.c. I became deeply interested in this line of research, and resolved to visit the sites being excavated by the Italian Archæological Mission in Crete and try to see for myself these traces of prehistoric man. Remains of buildings dating from the Bronze Age 
had been found at a depth of $5 \frac{1}{2}$ metres, and then the excavations had been carried down for other $6 \frac{1}{2}$ metres, with the result that only stone implements were found before the virgin soil was reached.

Dr. Evans bases his Chronology on a comparison of the pottery found by Flinders Petrie ${ }^{1}$ in Egypt with that found in Crete. It was known that some vases discovered at Abydos, with black polished surface decorated by hand with geometrical designs, were not of Egyptian manufacture. When Dr. Flinders Petrie went to Knossos he recognised that these vases are identical with those found by Dr. Evans at the depth where the remains of the Bronze Age begin. It was therefore certain that the non-Egyptian vases of the first dynasty found in Abydos are contemporaneous with these Cretan vases. ${ }^{2}$

Before the time of Minos commercial relations had already been established with Egypt. During the first four dynasties stone vases which were not the work of Cretan masons were brought into the island, and a whole series of stone vases made in Crete were found exactly resembling the Egyptian models of the first dynasties. These are the data on which Dr. Evans bases his opinion that the strata in the Court of Knossos at a depth of 5 metres correspond chronologically with the first Egyptian dynasties.

The enormous stratum of remains found on the summit of this hill of Knossos represents the leavings of a people established there for centuries. It is black earth consisting of layers of charcoal and ashes with bones and potsherds. Dr. Evans, in making an approximate calculation of the number of centuries during which man dwelling on this hill could have accumulated a layer of rubbish and sherds above 6 metres deep, reasoned that in the Stone Age the soil probably rose less rapidly than in the Bronze Age, because a more advanced civilisation produces a more

I A. J. Evans, "The Palace of Knossos," Annual of British School at Athens, 1903.

2 D. Mackenzic, "The Pottery of Knossos," Fournal of Hellenic Studies, vol. xxiii. pp. $15 ;-205$. 
rapid accumulation with more solid and massive constructions. To avoid exaggeration he allowed that the increase might be equal, and that the deposits in the Bronze Age and in the Stone Age might be uniformly superimposed so as to extend to a stratum 12 metres thick. Accepting the calculation of the most competent ligyptologists, we get 5800 years for the first $5 \frac{1}{2}$ metres; and allowing that the detritus below would accumulate at the rate of I metre in every thousand years, we arrive at twelve thousand years.

II.

Having first paid a visit to Sicily, in order to examine the soil of the Neolithic periol which had been studied by Professor Orsi, 2 and where potiery similar to that of Knossos had been discovered, I set off to Crete. An eight hours' ride across the island brings one from Candia to Phastos, where the famous ruins of the palace discovered by the Italian Archrological Mission are situated. The magnificent valley of Messara is closed in towards the sea by a hill (Fig. I). On the truncated cone in the centre of the picture is a smooth slope which descends almost precipitously past the steep rccks. Upon this slope stand the ruins of two palaces, one above the other, which have been described by Dr. Luigi Pernier. 3 Fig. 2 shows the base of these edifices.

The most ancient had a theatre in front, which I will describe later. Here we see the theatral area formed by a great court traversed obliquely by a raised path leading to the royal podium, another path diverges from this at right angles to the right.

The base which lies horizontally across the illustration forms

I The latest period during which only stone weapons and implements were used is teimed Neolittic, to distinguish it from the most ancient, or Paleolitbic, of which no trace has been found beneath the ruins of the palaces of Knossos and Phxistos.

2Orsi, "Stazione neolitica di Stentinello," Bullitino ii Paletnologin, Dicembre, I 890 , p. 17\%.

3 "Scavi della Missione italiana a Phæstos," Somumenti anticli, I900-190 I, vol. xii. p. 16 et seq. 
the plinth of the most ancient palace, which was built on the level of the Neolithic Period. It was destroyed by fire at a period before the civilisation with which Schliemann made us acquainted by the excavations of Mycenæ. All the household goods were left among the masonry, and it was not long before a second palace was built, of which the great flight of steps is seen in Fig. 2.

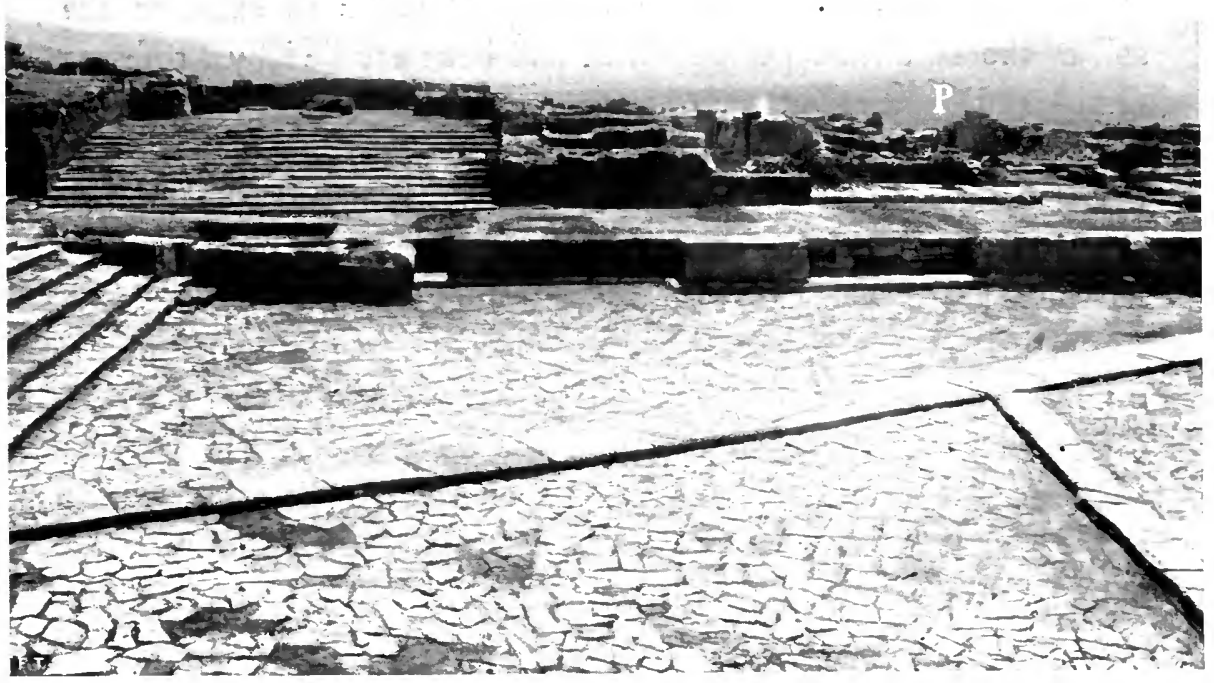

FIG. 2.-THE RUINS OF THE TIIO PALACES OF PHASTOS AND THEATIRA, AREA.

$P$ marks the place where I began to excarate.

To prepare the ground for the rebuilding of the palace a thick layer of lime mixed with clay and pebbles had been thrown upon the remains of the ancient palace. This plaster became as hard as a rock, and has now to be broken up by explosives in order to recover the objects below. My excavations began to the right of the spot marked $\mathrm{P}$, where there is a pithos, or great jar, as tall as a man. 
The place where I was excavating is best seen in Fig. 3, and is part of a series of chambers which served as magazines. The great blocks of which the walls were built are visible. In the first of these chambers I removed the pavenent and excavated a pit $5 \frac{1}{2}$ metres deep down to the virgin soil. Fig. 4 shows this pit, which was slowly and carefully excavated and the earth,

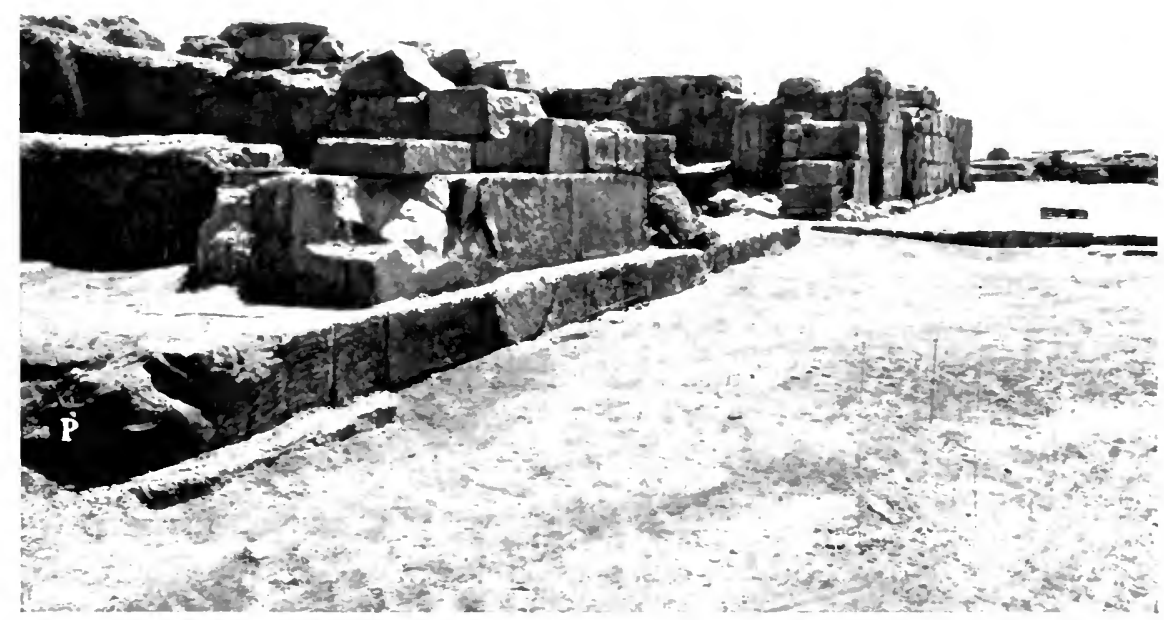

FIG. 3. - CHAMBERS OF THE MAGAZINES WHERE I EXCAVATED DOWX TO THE VIRGIN SOIL.

The pit of Fig. + Was made in the room P' in the left-hand conner.

masonry, and all the contents removed. The pit measures i 6 square metres, the sides being + metres long. The soil removed from it is of a characteristic brown colour. I Beneath the pave-

I Similar earth is found in the valley of the Po. The peasants call it terramara and use it to manure the land. Gastaldi, Pigorini, and others who have studied the mounds of this earth have shown that prehistoric dwellings existed there. 
ment were bones and teeth of animals, potsherds, stone weapons, and horizontal strata of charcoal and ashes.

I excavated the other rooms near in the same way as far as the end of the corridor, where there is a great court paved with polygonal blocks of limestone (Fig. 5). The corridor of Fig. 3 ends opposite the great stone to the right of the wall which forms the central division of Fig. 5. I made another excavation in the centre of the court and another on the righthand margin of Fig. 5, where a pithos is half buried in the pavement. A landslip has carried the end of the court with part of the palace down to the valley below.

Ihe depth of the pits excavated down to the virgin soil diminished gradually as they approached the central court, till in this court there was only half a metre of Neolithic earth beneath the pavement.

The distance from the last room (in which I excavated the pit of Fig. 4) to the court is 30 metres. Within this short space the pits vary gradually from half a metre to $5 \frac{1}{2}$ metres in depth from the pavement to the virgin soil, the upper level on which the palace stands being nearly horizontal, while the Neolithic stratum beneath rests on the slope of the hill.

In his description of this palace Dr. Luigi Pernier I says that this hill had been abandoned at the close of the Neolithic period, and that the Neolithic remains upon the hill have been carried down the slope by natural forces. From the evidence of the excavations which I carried out with him this year, which have shown the different strata of earth with the charcoal and potsherds all well preserved and distinct, it seems to me more probable that the top of the hill was levelled when the primitive palace was built and the upper court made.

I shall not describe here what I found in excavating, as it will form the subject of another work, but will only say that the inhabitants were in a fairly advanced stage of civilisation and had

I "Scavi della Missione italiana a Phæstos," Monumenti antichi, Accad. Lincsi, vol. xiv., 1905. 


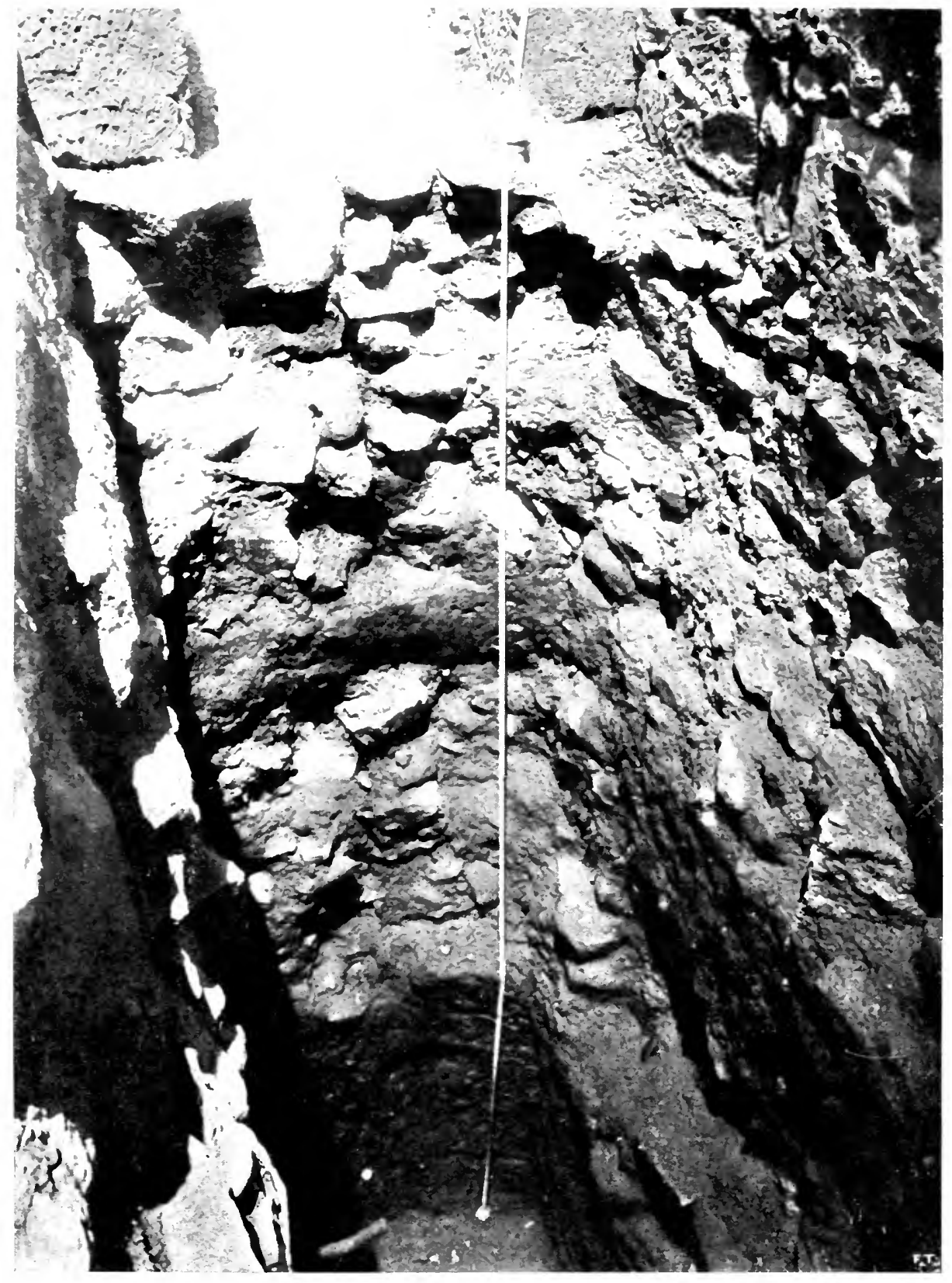

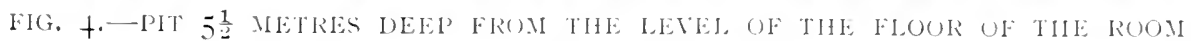
M.AREEI) I' IA IFIG, 3. 

stone weapons and knives of obsidian which came from the Isles of the Aigean when they arrived here.

I was able to confirm the result of Dr. Mackenzie's investigations as to the black pottery upon the virgin soil being plain. A little higher appears pottery with decoration of punctured dots and lines. In a later period the decoration of pottery becomes more complex ; imitation of basket work is found, and the deeply incised lines are filled with white chalk. The vases become more elegant and have decoration in white on a black ground. 'This pottery is identical with that found in the Troad and in Sicily. The Neolithic stratum is above + metres deep, and according to Dr. Evans's calculation man must have dwelt on this hill, using only stone weapons for above four thousand years before he was aiquinted with bronze.

When black pottery with white designs had been brought to perfection another kind of coloured pottery began to be made, and fragments of both are found together. The Cretans knew that their fathers had made this shining black ware, and they kept these vases for religious functions many centuries after they had given up the manufacture of black pottery. This shows the persistent survival in religious rites of the traditions of primitive life.

This black pottery, or bucchero, as it is usually called, is found in Greece, Crete, Sicily, and Italy. Vases with the same decoration, the same obsidian knives, and the same stone axes were in use and the same idols were worshipped. These facts are important as they show that communication by sea was at that early age more frequent than has been believed. There was a uniform and widely extended civilisation which lasted for a longer time than the long period which began with the beginning of history and las lasted till our own day. The level of this culture was fairly equal in Southern Europe, in Italy, Crete, and Egypt, and upon this stratum of uniform culture in the Mediterranean basin the civilisations of Egypt and Crete developed contemporaneously but in different fashion. 
III.

'Two labourers are sufficient for the excavation of one pit. One shovels the earth into a large matting basket, which another man draws up from the pit. The earth is carefully examined both in digging and in putting it into the basket, and the bones and potsherds of each stratum are kept separate in a basket, and a wooden label attached to the handle has a number written on it and also the depth at which the objects were found. From time to time we found obsidian knives, sherds of bucchero, beautiful handles of black glazed vases, grey ashes, bright charcoal with concentric strata radiated as in oak brands. About 2 metres from the foundations of the latest walls I found a stratum of very pure clay, 5 or 6 centimetres in thickness, which left a red stain. There was a large store for making fine pottery, and it had probably been forgotten during the Neolithic Period.

I spent some delightful days among the labourers, sitting under my umbrella at the edge of a pit watching the men as they cleared it out with pick and shovel. Everything was brought to me, and one day came a black object within a clod of earth. I opened the clod with my nails, washed the object in the tub of water which was used for the potsherds, and found the statuette of a woman of exuberant forms like the idols of the Stone Age, without head or arms. On the right side is a cross, probably a tattoo mark. ${ }^{\mathrm{I}}$

So as to lose nothing I went through every clod, breaking it up into dust. That morning I had found a heavy stone, of the size of my fist. I ran to wash it and saw that it was a piece of iron. This very rare object was found at a depth of 4 metres in the same place as the idol. In shape it is a quadrangular pyramid with the angles blunted and the base slightly convex. On the bright surface are wrinkled cavities and depressions. It weighed half a kilogramme, reckoning the missing piece at I०० grammes.

I Fig. 131, Chap. XIII. 


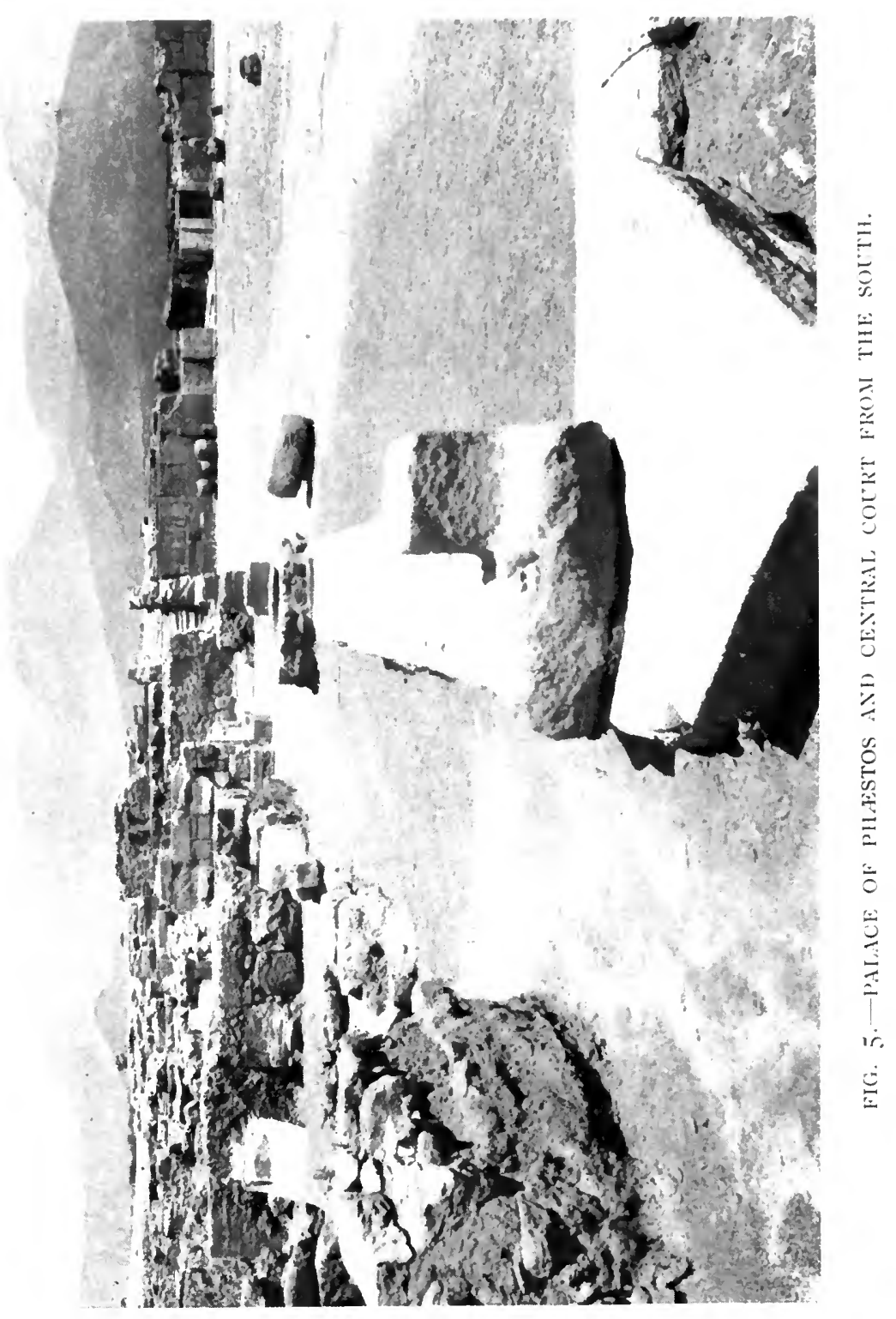



When I was about to make a chemical analysis of it I could find no file that would cut this stone, so hard was it. I tried to chip some off with a scalpel and the substance split, showing that it had never been hammered. Otherwise it would have broken to pieces. This magnetite is black inside. According to the analysis it consists of oxydized iron.' We may be certain that it was a sacred stone from the fact that the Neolithic folk had not made a weapon or a hammer of it. Possibly they believed it to be a meteoric stone: it was known at that

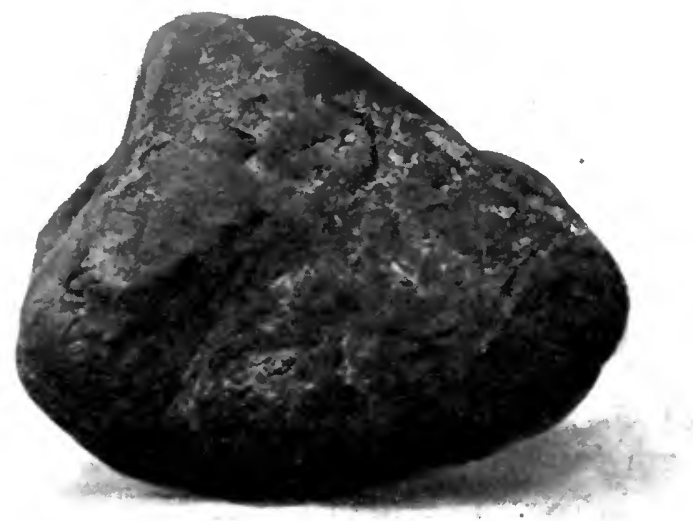

Fig. 6.-PIECE OF MAGNeTtTe FOUND, AT A DEPTH OF + Mirtres, IN THE PIT (FIG. +) NEAR A TERIRACOTTA FEMALE FIGLRE.

period that these stones came from heaven, for they appear with a luminous track and fall to earth with a sound. That it was a cultus object we may be sure from its having been found near an idol.

$\begin{array}{llllll}x & \text { Magnetic oxide of iron } \quad \ldots & \ldots & \ldots & 96.58 \mathrm{I}\end{array}$

$\begin{array}{lllll}\text { Silica and aluminium... } & \ldots & \ldots & \ldots & 3.169\end{array}$

$\begin{array}{llllll}\text { Oxide of manganese } & \ldots & \ldots & \ldots & \ldots & 0.150\end{array}$

Loss and other substances not weighed $\quad . . \quad 0.100$

Specific weight $\quad \ldots \quad \ldots \quad+.86$ 
IV.

Knowing that the object of my journey was to seek for skulls and skeletons of the Bronze Age, Dr. Hazzidaki took me to a place in the valley of S. Paolo, below Phæstos, where fragments of terracotta sarcophagi are often turned up in ploughing. The labourers were beginning to cut the unripe corn in order to make cuttings at the points which Dr. Hazzidaki had marked out.

A peasant told us that twenty years ago his father had found here a large tile while ploughing. On raising it he found a tomb within which was a skeleton with a gold necklace and bronze vases around.

On the first day we found some large limestone blocks, about I metre in length, forming part of a wall with a plinth (Fig. 7). It appeared to have been the base of a Mycenæan edifice, but some fragments of great jars gave us the impression that it was an archaic Greek building, for the fragments had on the edge the one a design of spirals, the other, of almonds, which were not of the Mycenæan period. We were full of enthusiasm. So ancient a building could only have been the temple of Rhea, Mother of the Gods. An inscription of Magna Mater ${ }^{\mathrm{I}}$ had been found close by in $\mathrm{I} 88_{4}$, and also a mould for stamping in relief small figures of Artemis of surprising beauty.

While the workmen were excavating we went through all the female divinities. In Rome, too, there was a temple of Magna Mater in the Via dei Sepolcri and one of Mater Matuta. The lovely round temple with channelled colunns and Corinthian capitals near the Tiber indicates by its later name of Santa Maria del Sole its earlier one of Dea Matuta.

But we found nothing more, though on the following days our hopes revived and we thought we had found one of the tombs called tholoi when we came upon a series of large stones disposed

I Pernier, Rendiconti R. Accad. dei Lincei, 1901, vol. x. p. 265 . 


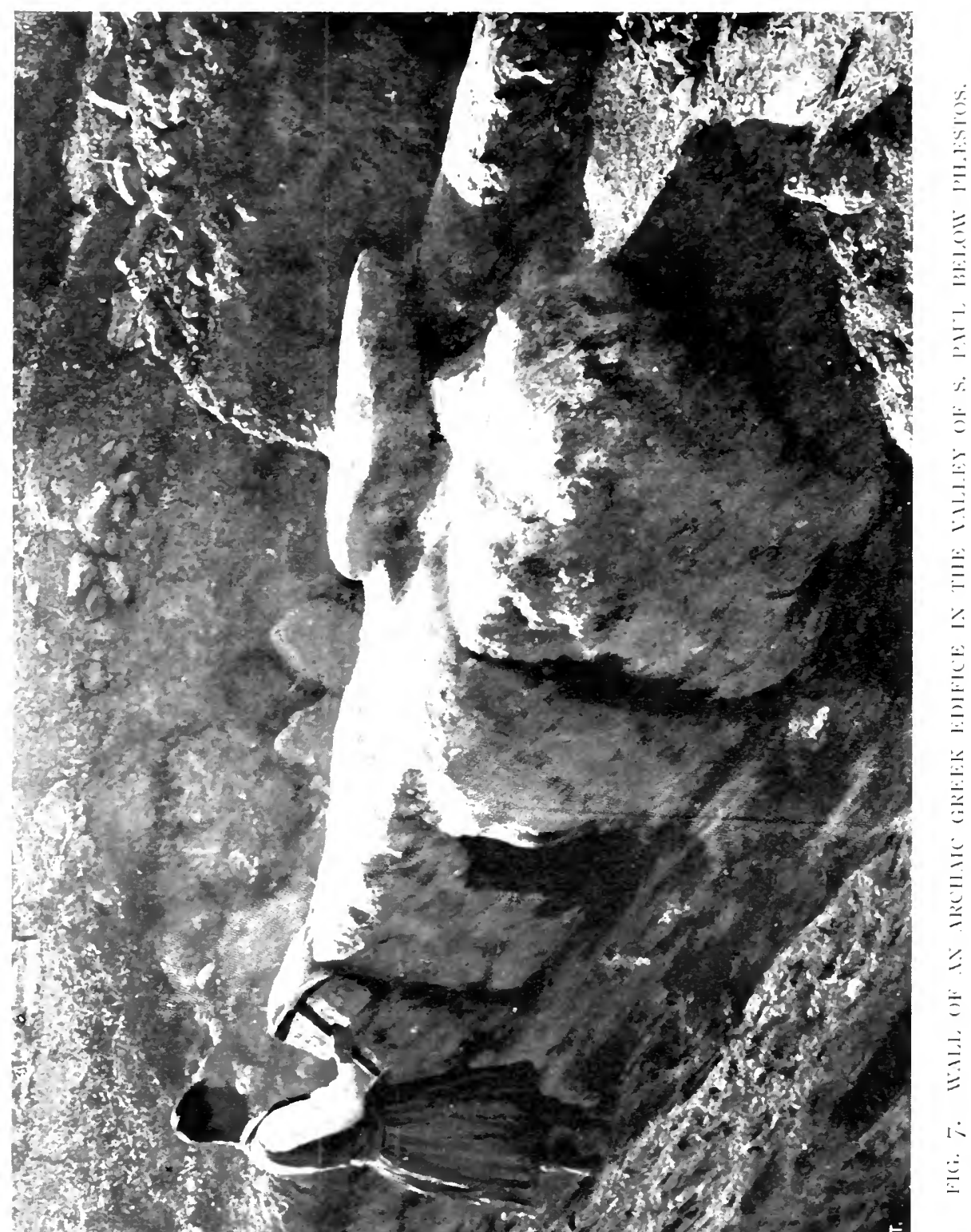



in the form of an arch. We found that this construction had been pillaged in ancient times. There was, however, so great a number of sherds in the trial pits which we made to try the ground, that I resolved to continue the search. Dr. Mancini, a student of the Italian Archæological School, had just arrived, and I proposed that he should help me to enlarge the trenches in various directions. Two days later we found a wall belonging to a Greek building. On the third day we found two great

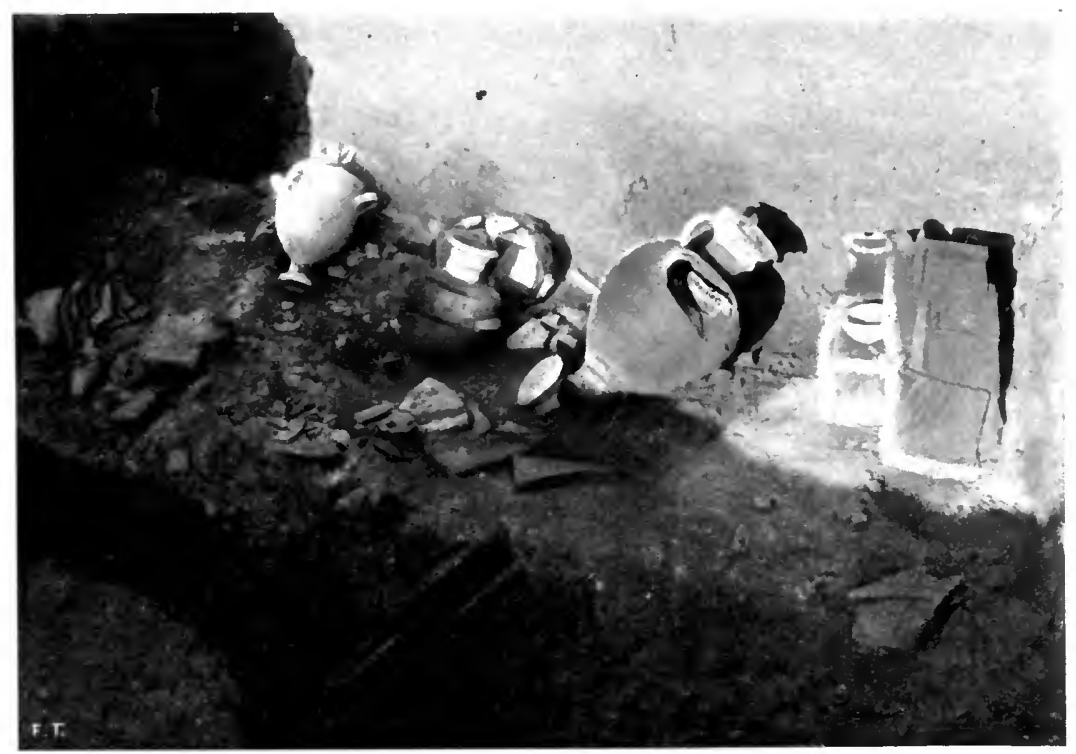

FIG. 8.-BOTTON OF A TREXCH. AMPHORA, HYDRIE, CUPS AND TILES FOUND IN THE CELLAR OF A GREEK HOLSE.

hydriæ I and two amphoræ, with good designs, among cups "and vases of various shape.

Fig. 8 represents the bottom of the cutting with the vases in place. Two hydriæ (Figs. $9 a$ and $b$ ) are shown separately. We probably came upon the cella vinaria of a Greek house: in it we

${ }^{1}$ The hydria, Fig. 9a, is exactly the same in shape, size, and design as one found by Alessandro Palma di Cesnola in Cyprus (Salamina, Firenze, I906, p. 262, Fig. 279). 
found some very fine black vases, cups, tiles, and seven astragali of blue glass paste with metallic reflexions. I

V.

The most intense excitement which I have ever felt is that of excavating. An artist who is overcome by this passion should

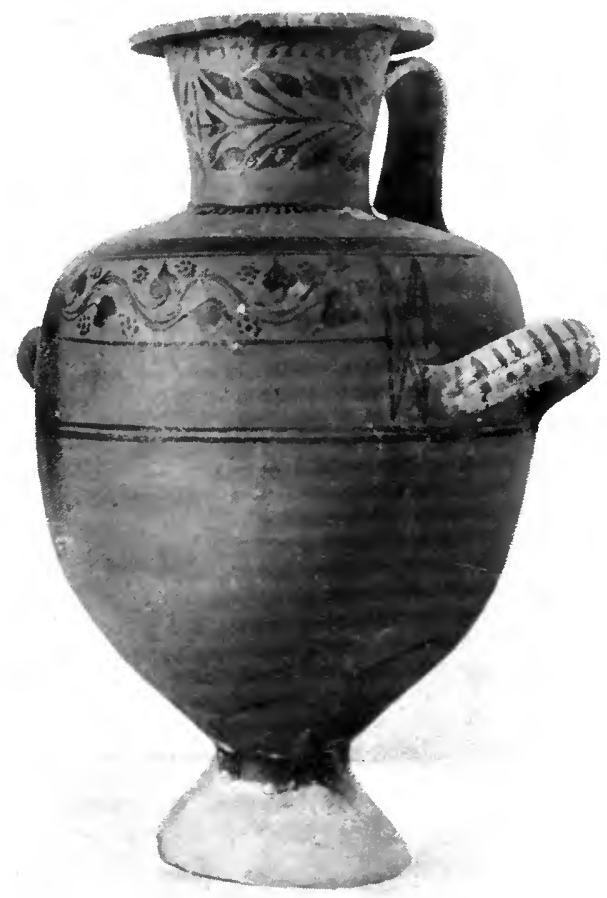

FIG. 9a.-HYDRIA FOLNI) IN THE TRENCH OF FIG. 8 .

describe the surroundings in which archæological researches are being made, should reproduce from life the anxiety of the first attempts, describe the technique of the pits and trenches, and the

T'The virgin soil in the field of olives, where we made several cuttings, is found at the depth of from $I \frac{1}{2}$ to 2 metres, with fragments of tiles. In the pit shown in Fig. 8 I put in the right-hand corner some of these broken tiles. 
coming to light of the documents which speak when history is silent. If the artist and archaologist could transmit to the reader the enthusiasm and excitement which he feels while standing among the labourers when the pick gives a hollow sound and the ground echoes as a presage of new discoveries,

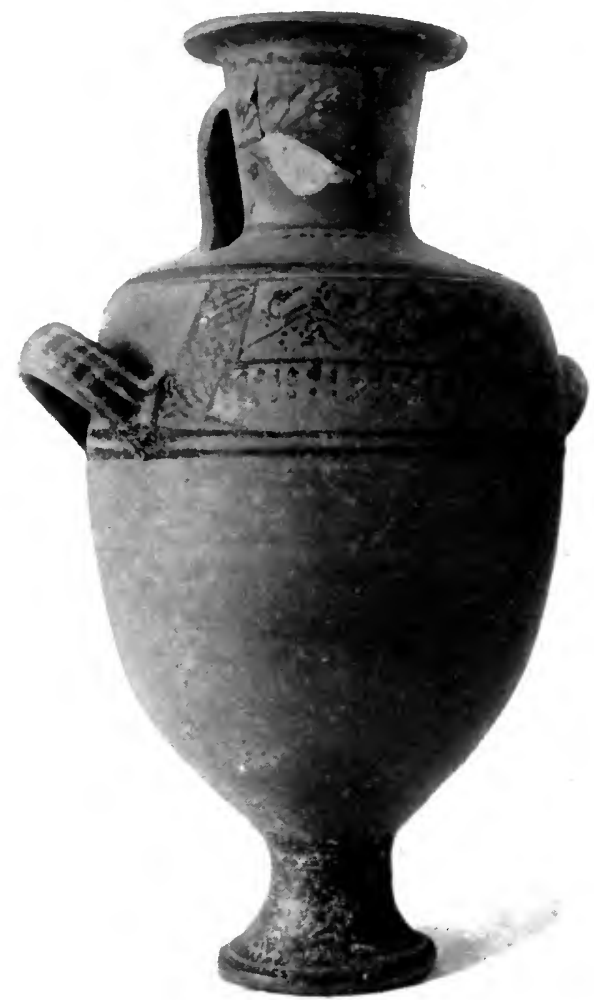

FIG. gb.-HYIRIA FOCNI) IN THE TRENCli OF FIG. 8.

if he could show the hands which tremble as they grope in the earth, or timidly pass over the fragments of a work of art,

They are thin and of well-baked clay but without stamp. I leave it to archrologists to decide if these hydrix and vases of classical form must be attributed to the second or third century B.c. 
to remove the coating of dust which hides it, if he could explain the hidden power of excavation to exalt the mind, and the insistent, almost childish call on fortune to grant new treasures, he would write, not a book, but a romance, a drama of the human soul which seeks the unknown.

Certain psychological refinements cannot be imagined by the poet-he must have felt them, it is not enough to be a writer to describe excavations. The soul must rise and vibrate in the highest realms of science and feel the impulse to clear away the darkness which veils the unknown. The heart rather than the intellect must palpitate with the fever of research-the sacred fire which intoxicates until the mind attains to the revelation of an almost superhuman dream, in which the secrets of history are seen beneath the earth.

The writer who could reproduce these emotions in the poetic surroundings of the Hellenic landscape would find a new and inexhaustible spring of poetry, for our inner life becomes more intense in the presence of the origins of our civilisation.

\section{VI.}

I was fortunate in being present this year at Dr. Luigi Pernier's excavations at the foot of the great staircase of the Palace of Phæstos. Fig. Io shows how the space between the two palaces was reduced by the excavations.

In the room at the extreme left of the illustration and at the foot of the staircase is a vase for libations such as was used in the sacred rites, a marble tablet and two grinders with the handle, which had been used for preparing colours.

In the next room were found a group of lamps and a stone cup, also a jug and a small stone pestle and mortar. Here and there lay fragments of coloured vases with white lines on a black ground, and some jug handles.

It is most exciting to pull out these pieces of variously coloured pottery, seeking them among the earth and charcoal and putting them together, after studying the shapes of the 


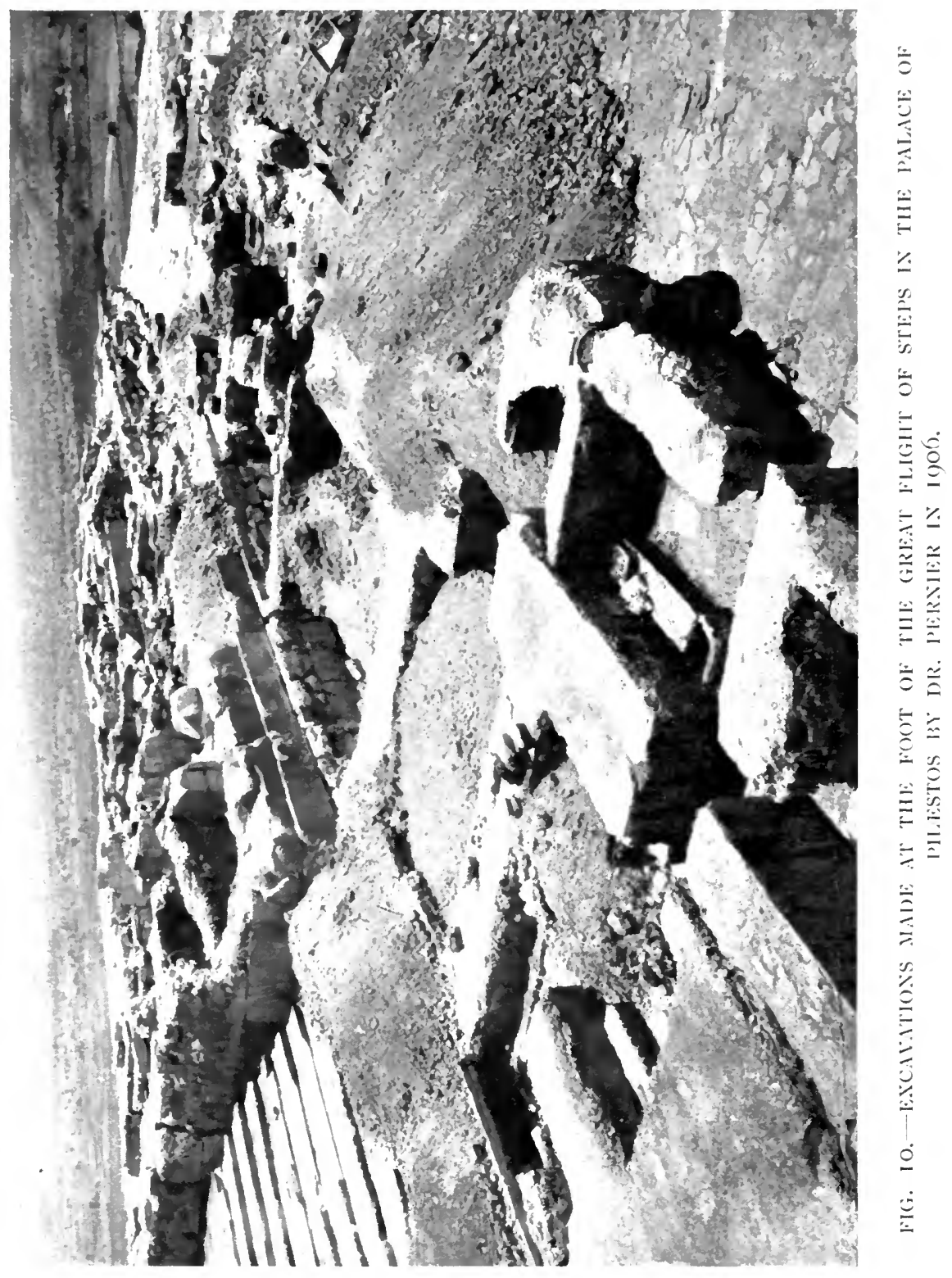





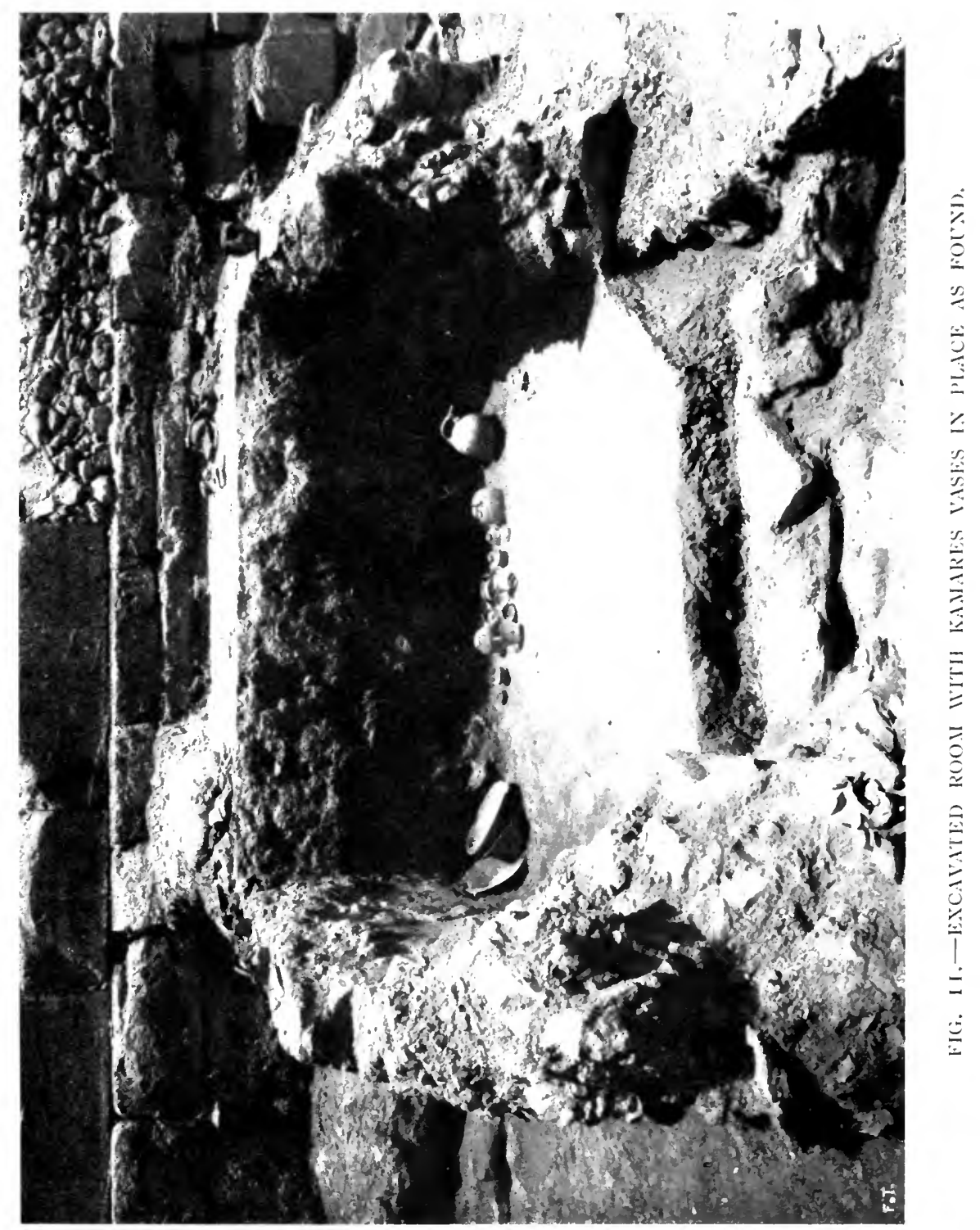



unbroken vases. To show the abundance of our booty, I give the photograph of one of the rooms in which Dr. Pernier left in their places the beautiful perfect cups and some other vases of red clay with white and yellow designs and graceful curves, jugs and lamps of various shapes, some with pedestal and others with a long handle, made of red clay (Fig I I). In the next room were found vases like our fruit dishes, which had the handle in the centre of the concavity. I saw brought out from the charcoal a very delicate cup of brown clay, with an impressed design of shells, and a small spherical vase resembling the fruit of the horse-chestnut. On one side are the excrescences of the outer shell; on the other side it is smooth like an Indian chestnut which is just opened and shows the fruit. It was supposed that this tree came from Central Asia, and for that reason it received the name of Indian Chestnut, but it is now known that it lives in a wild state in Greece. The little vase which we found adds another proof to botanical history, showing the antiquity of the existence of the horse-chestnut in the Isle of Crete.

I have a lively and exact recollection of each find, for a sort of heightening of the power of perception for this new work had arisen in me, and I gave myself up to it with youthful enthusiasm.

A certain type of pottery goes by the name of Kamares, having been first found in a cave above the village of Kamares. The entrance of this cave in the chain of Mount Ida is visible to the naked eye from the Palace of Phrstos. The discovery of this pottery in a mountain cave illustrates the religious tendencies of the Minoan people to nature-worship. These vases were found soon afterwards in several parts of the island, and their style and characteristic form became at once famous.

It is the triumph of polychrome with curious and elegant motives and perfection of design. The composition is charming - with white rosettes on the black ground and elegant foliage freely drawn with the brush, small concentric circles with a frieze of radiating brush marks, lines and borders of various colours 
and branches which are twined like a garland round the jugs and cups. ${ }^{\mathrm{I}}$

A page from my notebook will best describe my day's work in the excavations. ${ }^{2}$

$$
\text { "May 16, } 1905 .
$$

"To-day I helped Dr. Pernier to get material from beneath the astracasvesto. 3 Among the charred wood we found some

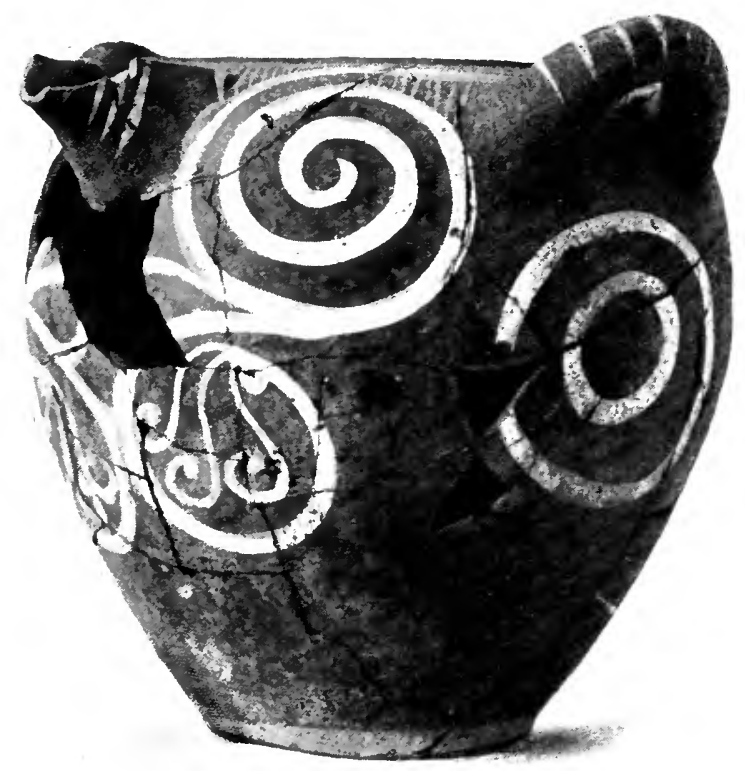

FIG. I 2a.-KAMARES JUG. EXCAVATIONS OF IgO6, PALACE OF PHASTOS.

thin plates of gold which had probably ornamented a small piece of furniture. There were the remains of a cabinet with quad-

I Dr. Evans is able to fix with certainty the date of these vases, which are more than four thousand years old, for Dr. Flinders Petric has found the same vases at Kahun in Egypt, at the period of the XIIth Dynasty.

${ }^{2}$ Extracts from my pocket-book are enclosed in inverted commas throughout this book.

3 The mixture of lime, clay, and stones, used to cover the ruins of the most ancient palace, is called by the Cretans astracaszesto. 
rangular tablets of very hard terracotta which fitted together, and some cornices in repoussé work with undulating designs, resembling the cornices which were in fashion at the beginning of the last century.

"From these fragments I understood how far advanced were these people in the manufacture of furniture. The wood had been destroyed by time, and only the ornaments of bone and of a very hard terracotta resembling porcelain had been preserved.

"In a cupboard-like recess in the wall at the height of I metre were objects of the Neolithic Age-polished flints and remains from the manufacture of stone utensils, showing that these primitive folk did not neglest ancient things. The artists

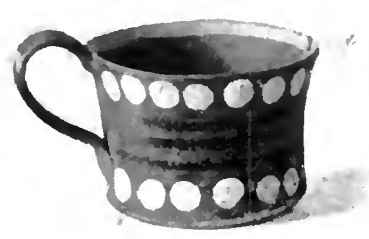

FIG. I $2 b$.

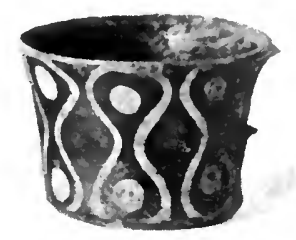

FIG. I $2 c$,

KAMARES CUI'S. PALACE OF PHASTOS, 1906.

who occupied these rooms and used these colours and grinders knew that their forefathers had used implements of stone and preserved these relics with respect.

"I collected a handful of scorched peas, which are exactly like our own. On the pavement was the large jug and two cups (Fig. I 2), decorated with interlaced spirals in white, with circles and undulating lines.

"Modern Cretan houses have in the walls the same recesses, termed dulapi, as the Minoan house. In one of these recesses Dr. Pernier found the two-handled jug (Fig. I 3 ) and a cup, with white linear decoration in the same style. Everything was in place as on the day of the catastrophe, though more than four thousand years had passed. I thought of the lapse of time as I 
drew out the cup intact, and, emptying the jug of earth, I sought for traces of the ancient wine." I

I I have to thank Professor F. Halbherr and Dr. Luigi Pernier for permission to use the photographs of some objects discovered by them and not yet published.

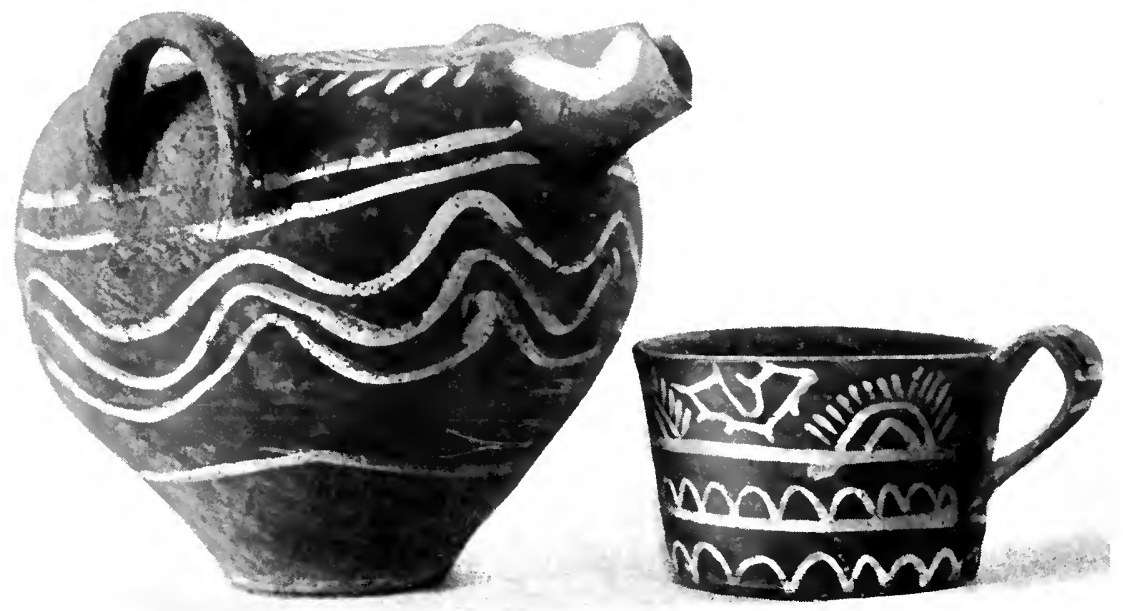

FIG. I3.-KAMARES JUG AND CUP. PALACE OF PHASTOS, IgO6. 


\section{CHAPTER II}

THE PALACE OF PHASTOS

I.

I the month of June, I goo, the hill of Phæstos was a corn field with a few roughly squared blocks of stone showing between the furrows. These stones induced the Italian Archæological Mission to attempt an excavation, and Professor Halbherr entrusted Professor Savignoni with the examination of the upper soil. He found a number of Mycenæan fragments, and the first trial pits were sunk, and in the course of the next few years the ruins of Phrstos were brought to light.

The view of the palace from the hill (Fig. It) much resembles that of Pompeii, except that at Phæstos the blocks of stone, the flights of steps, and the ensemble are grander and have a warmer almost golden hue. 'The palace overlooks the great valley of Messara, which is seen in the distance. The Venetians introduced the Mezzadria System into this fertile valley, and the name Messari is said to be derived from this. The sea, whence Cretan commerce brought riches and power, is visible from the hill towards the south, and in that direction lay the ancient port.

II.

One characteristic of Mycenæan palaces is the number of colonnades and the great number of doors in the same room; the Cretans were a people who loved the light and yet under- 
stood how to protect themselves from the sun in well-shaded rooms. Homer calls Phæstos "the well-built city," and it merits the title.

On entering a palace it is natural to stop and look at the flight of steps. Here this is of especial importance as no architect has ever made such a flight of steps out of Crete. The steps seen here are the original type of grand staircase from which were derived all the magnificent flights of steps in the monuments of succeeding ages. It is an important

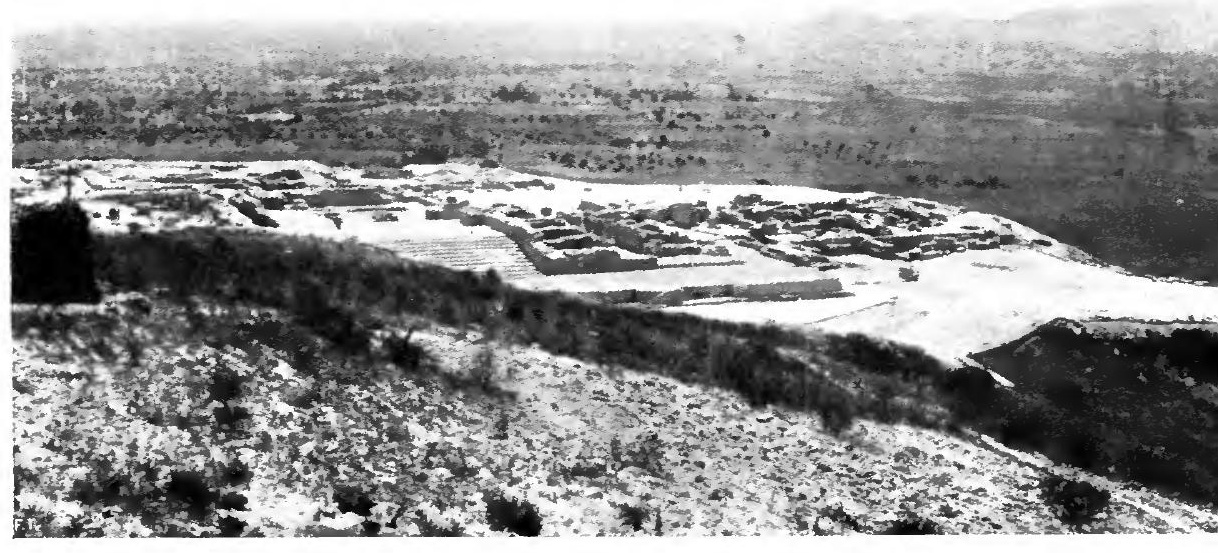

FIG. 1+. - RLINS OF THE PALACE OF PHASTOS.

record of the originality of Cretan art, for the Egyptians only, and no other people, had the idea of so convenient and vast a flight of steps for a princely dwelling. The steps are $13 \frac{1}{2}$ metres in width, 70 centimetres in breadth, and scarcely I 2 in height, and are made of large, well-joined slabs of limestone.

In Egypt the temples were built in such fashion as to defy the lapse of ages. Some of the sacred edifices of the Pharaohs, says Maspero, ${ }^{I}$ could be restored for the cult, to

$$
\text { I Maspero, "L'Archéologie Égyptienne," pp. } 8 \text { and I } 5 .
$$


all practical purposes, in a day or two, but the kings' palaces were built of bricks dried in the sun. We are acquainted with all particulars of the house of a prince of the XVIIIth Dynasty, including the plan of the garden, but no palace discovered on the banks of the Nile is like these of Crete. Here we have the intuition of pre-Hellenic genius leaving the primitive track of art. Not even in Rome do we find such grandiose style of construction.

Professor Lanciani, to whom I applied for details for comparison, tells me that the largest private staircase he found was in a Roman villa, and measures scarcely 3 metres 65 centimetres. The most celebrated public flights of steps in Rome were not more than 5 metres wide.

Not till the close of the Trecento (in the year I 384 ) was a great fight of steps constructed in Rome, and the record is a sad one. The steps of Santa Maria in Aracali were built of the marbles of the Temple of Quirinus, which stood on the Quirinal Hill on the present site of the Royal Gardens. It was one of the finest edifices built by Augustus, and now nothing remains but the colossal fight of above a hundred white steps.

\section{III.}

At the top of the steps in the Palace of Phastos there is one column in the centre, 6 metres from the uppermost step. Here is the vestibule of a hall in which the prince held solemn receptions. Three other columns stand in front of this great hall. ${ }^{1}$ There are visible traces of fire; the burning wood has blackened the alabaster which formed the socket of the wall.

A base of alabaster having been made (as shown on the pavement to the left in Fig. I6), holes were made in it to fix slabs of wood all round. 'These were bound together and the hollow was filled with a mixture of lime and rubble, even a piece of an amphora can be seen fixed in this plaster. The

I Between two columns is a great jar, which was probably placed there after the destruction of the palace. 
neck of this amphora with well-fashioned handles would of itself suffice to teach us that before the building of this palace the people already possessed an advanced culture. We know, however, that the Kamares vases were found on a lower level and that they are of earlier date than the second building of the palace.

The great reception hall of the prince was always open, for no marks of hinges are visible on the threshold. These marks are to be seen at the door leading to the staircase opposite. I In the right-hand corner near the door of the staircase in the centre of Fig. I 6 is a piece of painted plaster. There is a plinth in Pompeian red and a band above. The stuccoed walls were pale blue in colour.

On the right a door leads down two steps into a small room with benches along the walls, which was probably used as a waiting-room for the Court on reception days. This room has the walls lined with alabaster; the floor, too, is covered with large slabs and a very large slab formed the threshold.

\section{IV.}

In the walls near the jambs of the doors the sockets and grooves left by the bars and bolts by which the doors were secured are visible, and the bronze hinges have left marks of oxydisation on the pavement. The doors have left concentric lines of scoring, too, on the stone pavement where the wood has scraped it at a greater or less distance from the pivot hinge.

The ground plan shown in Fig. 17, which corresponds with the columns of Fig. I6, explains the superposition of the two palaces. Beneath the horizontal line of the pavement are the magazines of the primitive palace. More than thirty vases were found in place in three cells with niches in the walls, which served as store-rooms for food. When the palace was

${ }^{1}$ Dr. Pernier found in its place the bronze hinge of the door of the hall of the columns at the end of the corridor of the magazines near the central court (Fig. 3). 


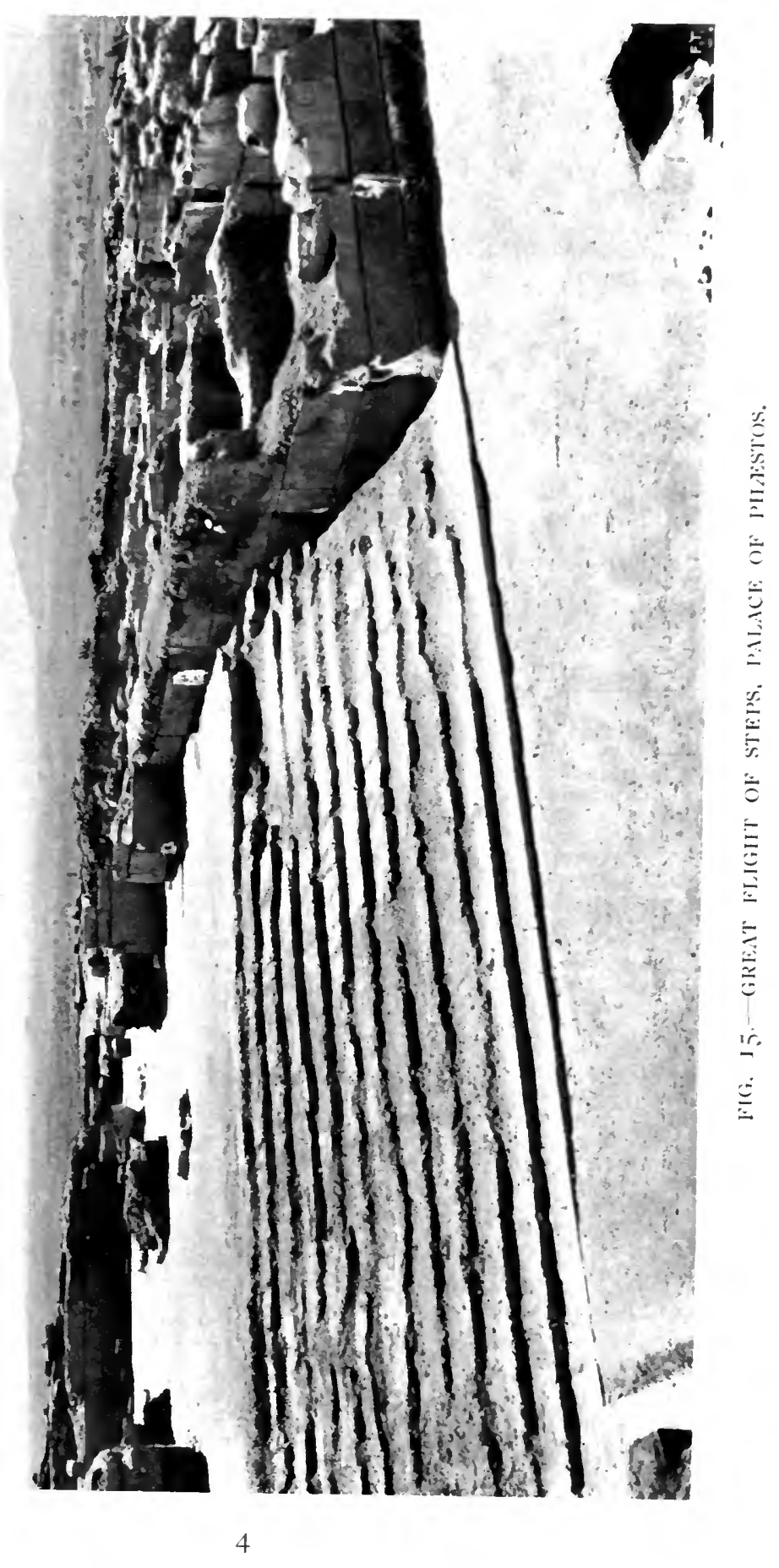





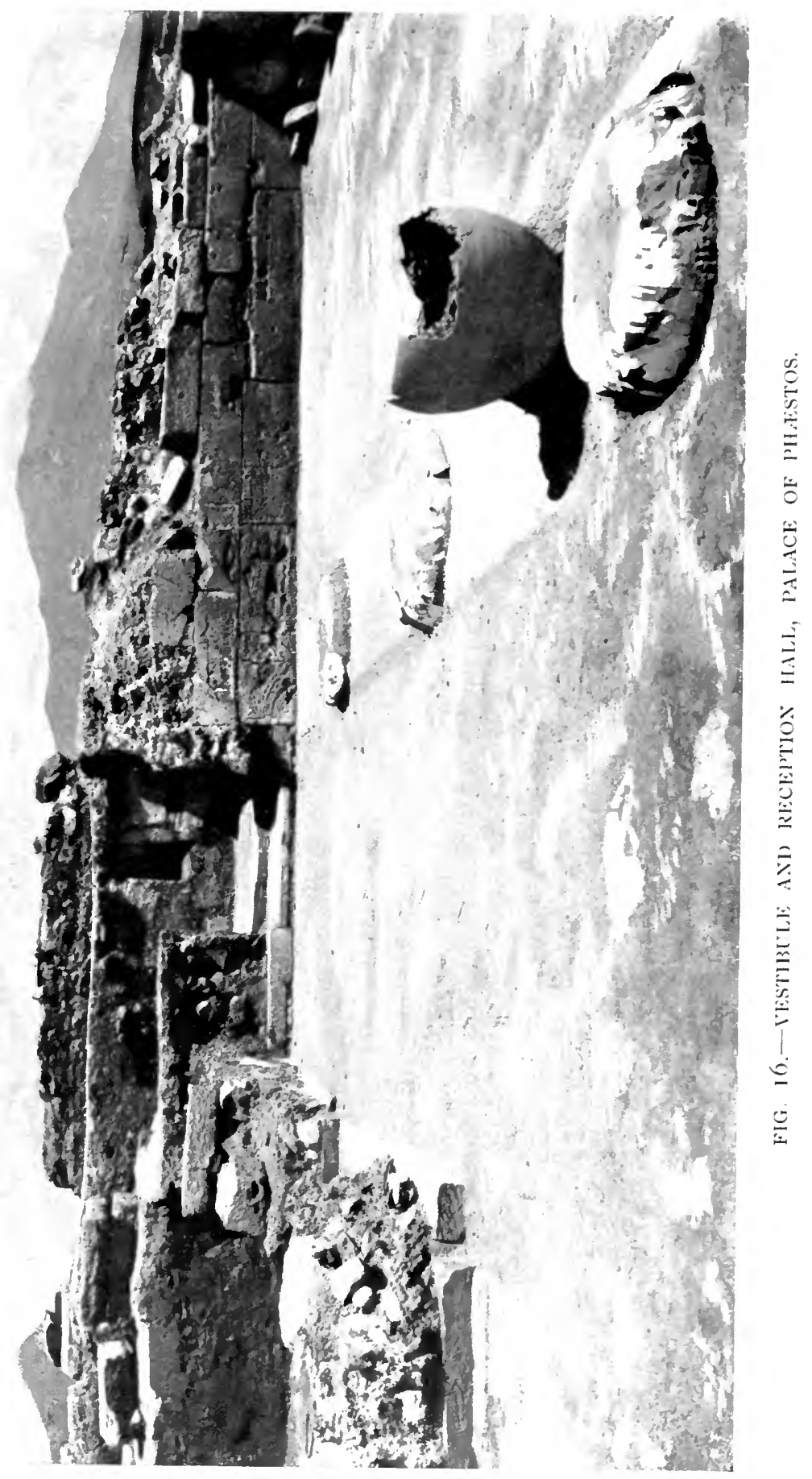



rebuilt after the fire, lime was thrown upon the levelled ruins and the objects beneath were left undisturbed.

Three of these beautifully decorated vases are reproduced (Figs. I8, 19, 20) and the others will be given later. The designs have been copied by the painter Stefani in the original colours ${ }^{1}$-brown, yellow, and red in delicate shades. The special characteristic of these vases is that they give the impression of being quite modern in style, and no one would imagine that this pottery is above four thousand years old.

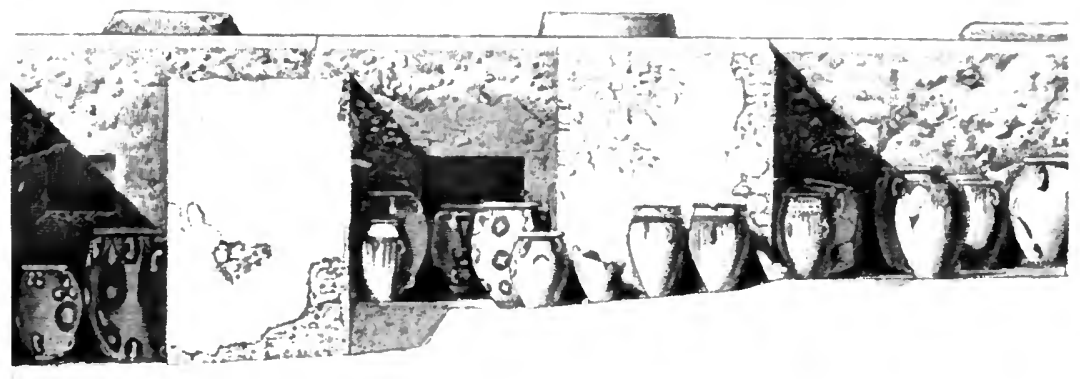

FIG. I7.- EXCATATION BENEATH THE VESTIBCLE OF THE SECONi PALACE.

Section near the three columns of Fig. I6 showing the rases as found in the magazines of the primitive palace.

The refinement of the Cretan princes may be recognised by the wealth of small details - for example, in the appointments - a vase would be placed on an elegantly carved slab of alabaster with a circular hollow round the foot of the vase, apparently intended to receive any oil or wine which might be spilt.

The artistic force of pre-Hellenic genius is shown in this splendid decoration of the humblest utensils such as the jars for holding alimentary substances in the magazines. The

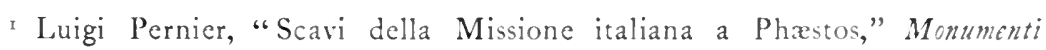
antichi, Accad. Lincei, 1902-1903, vol, xiv. 
princes of Phastos and Knossos lived in a luxurious fashion which we find nowhere else save in the colonies of Magna Grecia at the time when Syracuse was prosperous.

Few kinds of pottery surpass that of Kamares in artistic value. It is admirable both for its decoration and for the delicacy of the fabric. Lightness was the chief characteristic of this ware, which resembles egg-shell or Japanese porcelain. Some examples have the ornamentation in relief. A jug from Hagia Triada is in this style and appears to be an imitation of a vase in repoussé work.

This fabric had reached so high a grade of perfection that the makers had succeeded in giving to the ware certain metallic reflections which these vases still retain. The makers must have had before them vases of bronze, of which they have produced an accurate imitation. As the models had been made before the art of soldering was known, the bosses and folds of the metal are reproduced in the clay, and the method of attaching the handles is imitated.

The colours are generally red, orange, and white on a black ground. Sometimes the natural ground of brick red was kept with a design in white. One type is decorated in relief with applications of clay in the form of bunches of grapes, leaves, or ears of corn. The most famous specimens of Kamares vases are in the Museum of Candia and are of marvellous beauty. Some small baskets equal the porcelain of Saxony in delicacy; they are vases of very fine black porcelain with designs in white of rosettes, marguerites, and serpentine lines in black and white festoons. The cups are very light with small commas and spirals and other simple designs on the yellow slip, or of black clay with the ground painted in in white so that the black bucchero stands out in the design of rosettes and branches with small leaves with touches of yellow. 


\section{V'l.}

Our admiration for this pulace increases if we compare it with the poorer dwellings of princes described by Homer.

The account of the return of Odysseus from the Siege of

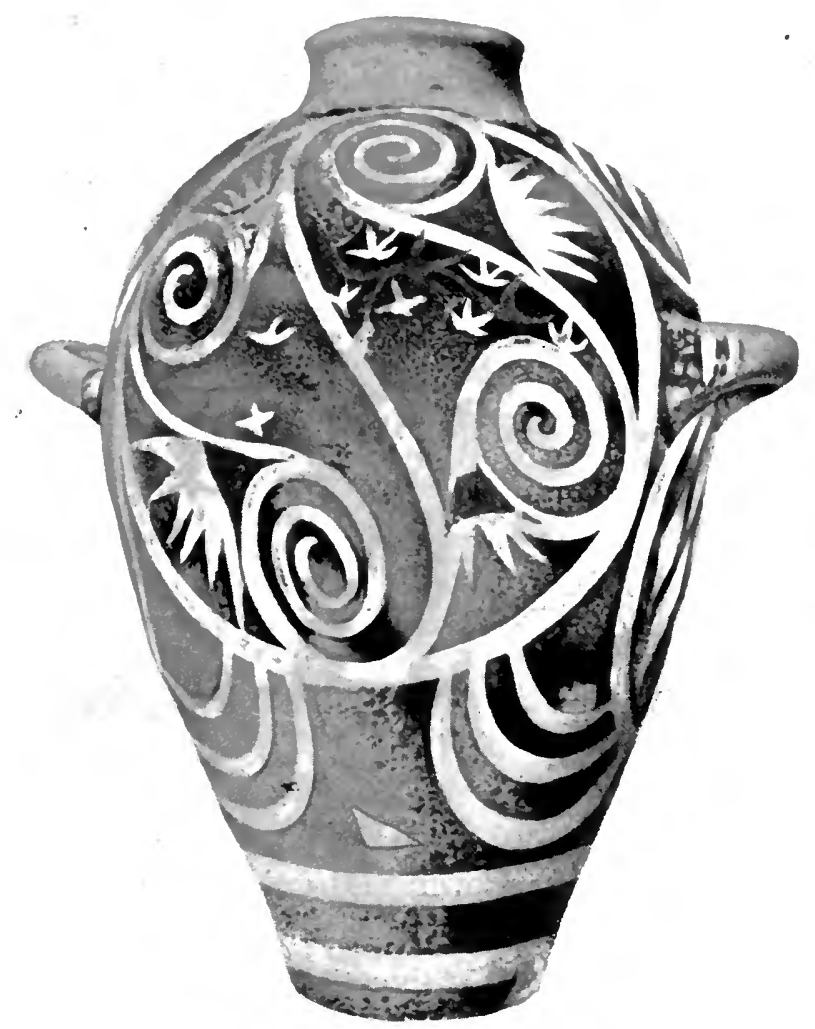

FIG. I8.- KAMARES VASE FOUND IN THE MAGAZINES OF THE MOST ANCIENT PALACE AT PHASTOS.

Troy in the Odyssey shows us the house of a king. In the single hall or Megaron oxen were slaughtered and skimned. Ctesippus, ${ }^{\text {I }}$ one of Penelope's suitors, in his anger against Odysseus, as they stood with the princes in the royal hall:

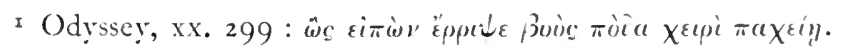


"From the basket took the bovine foot and hurled with vigorous hand, but with bending head the hero safe escaped it." Noack I thinks that the princes slept in this hall.

Odysseus lay down in the vestibule "on a fresh bull's hide and lambs' skins," the floor was of stamped earth, and Odysseus cut down an olive-tree and fixed upon it the famous bed which he had made himself, thus transforming a corner of the field into a nuptial chamber in the royal dwelling of Ithaca.

In building the Mycenæan palaces great use was made of wood. Large openings of the shape of tree trunks are seen in the walls, and carbonised beams are often visible among the stones. To the height of about 2 metres from the ground the walls were built of well cut blocks of stone, some of which are above $2 \frac{1}{2}$ metres in length and I metre in breadth. Above this solid base came the wooden building. Some of the blocks are still impregnated with bitumen from the action of the fire, for when the upper floors of the palace, which were chiefly built of wood, fell in, they burned slowly beneath the ashes. I saw one great carbonised trunk still in place, and was able to count the strata of its yearly growth. I think it was the trunk of a pine-tree or cypress.

\section{VII.}

I ascend the stairs (shown in Fig. I6) to the balcony to look at the view and to make a few notes in my pocket-book. Mount Id a rises above the sea like a great dome, and blue rocks fringe her snow-clad sides.

The outline of these mountains differs little from that of the Apennines, but the blue colour is more intense in Crete. Between the ridges the slopes fade in the distance till the blue blends with the grey of the sky. The villages look like eagles' nests perched on the cliffs, each girt round with a garland of olives, they too shading into blue. Above, the mountain becomes sterile and bare; below, we see patches of

I Ferdinand Noack, "Homerische Paläste," Leipzig, I 903. 
yellow field among the willows and planes in the shady windings of the river Geros Potamos.

Before the sun sets the shadows in the ravines of Mount Ida deepen into indigo, and the rocks of the whole chain become violet-an optical phenomenon rarely seen in the Alps. I The poets of classic Greece alluded to this violet colour

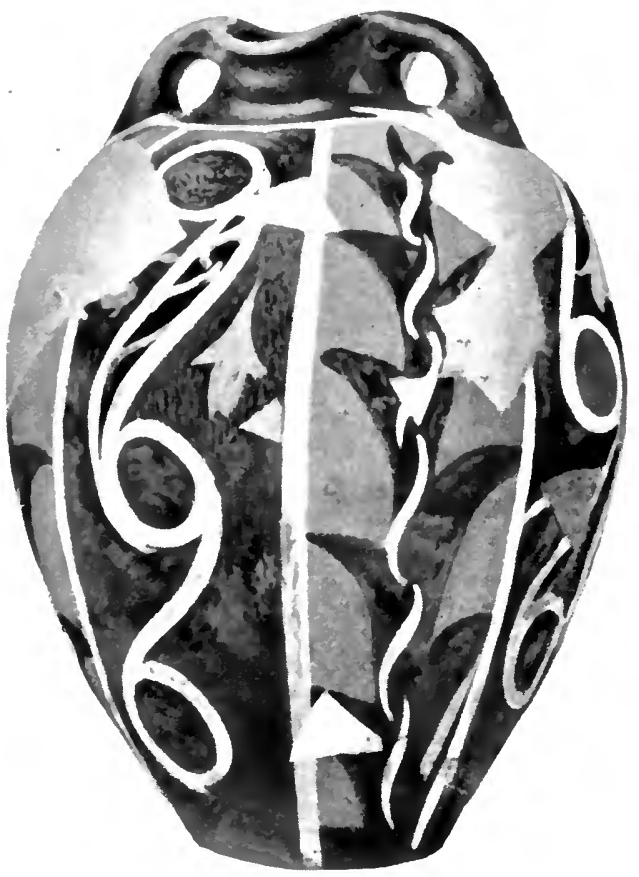

FIG. I9.

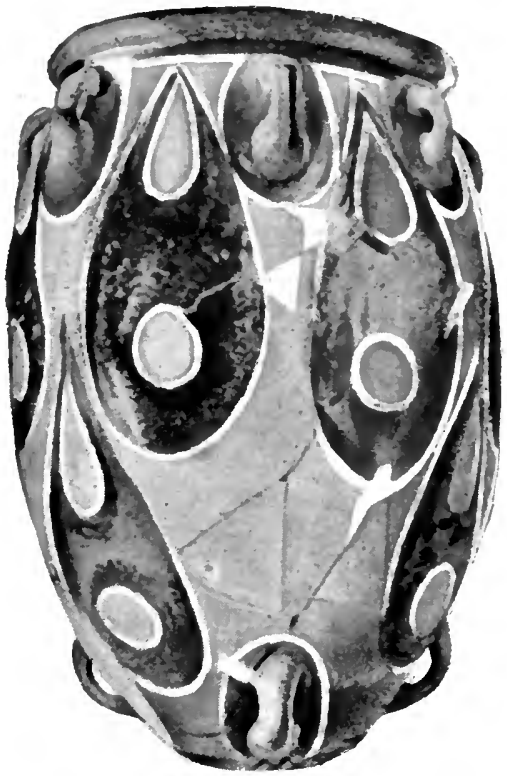

FIG. 20.

KAMARES VASES FOCND IN THE MAGAZINES OF THE MOST ANCIENT PALACL AT PHASTOS.

in the mountains round Athens. In Italy only the shadows become violet, but here in Crete the rocks are violet.

I look on the neighbouring hills covered with barley and wheat, and reflect that for centuries before Hellenic civilisation this hill presented the same aspect of cultivated land. When

I It is perhaps the effect of polarised light, but I had not a Nicol's prism with me to try. 
the Hegemony was lost and the palace destroyed, Phæstos was abandoned. The walls crumbled away, and in their dust grew the lichens and brushwood. When the Greeks again built houses and temples all trace of the Mycenæan constructions must have been lost, for the original orientation was changed and the foundations were built in the newer stratum of the fields. Yet the Hellenic structures are of so remote a period that when they were built history had not yet begun.

\section{VIII.}

Near the great halls for official receptions lie the magazines for alimentary substances. As there was no money in this early age taxes were probably paid in kind, or possibly the prince, possessing vast dominions, had to provide for a large number of officials, or even for all the inhabitants of his city, if we may believe the statement of Aristotle I that in Hellenic times the Cretan State fed at the public cost men, women, and children.

Some of these magazines are shown in Fig. 3, others which served as store-rooms for provisions are illustrated in Fig. 2 I. The huge blocks of stone impress us as part of a gigantic structure. I will explain later why the architects built these magazines with specially solid walls.

The magazines of the second palace are located on the righthand side near the grand staircase, the propylæum, and the reception-hall.

They consist of twelve chambers with doors opening on a corridor, in the middle of which stands the base of a pillar made of great cubes of stone. Within the cells were huge vases of oblong or spherical form with decoration in colour and reliefs made while the clay was still ductile. This fashion of working clay with the stecca was the most general form of ornamentation. Serpentine bands of soft clay were applied to the body and neck of the jars, and they were then decorated

$$
\text { r "Politica," rii. }
$$




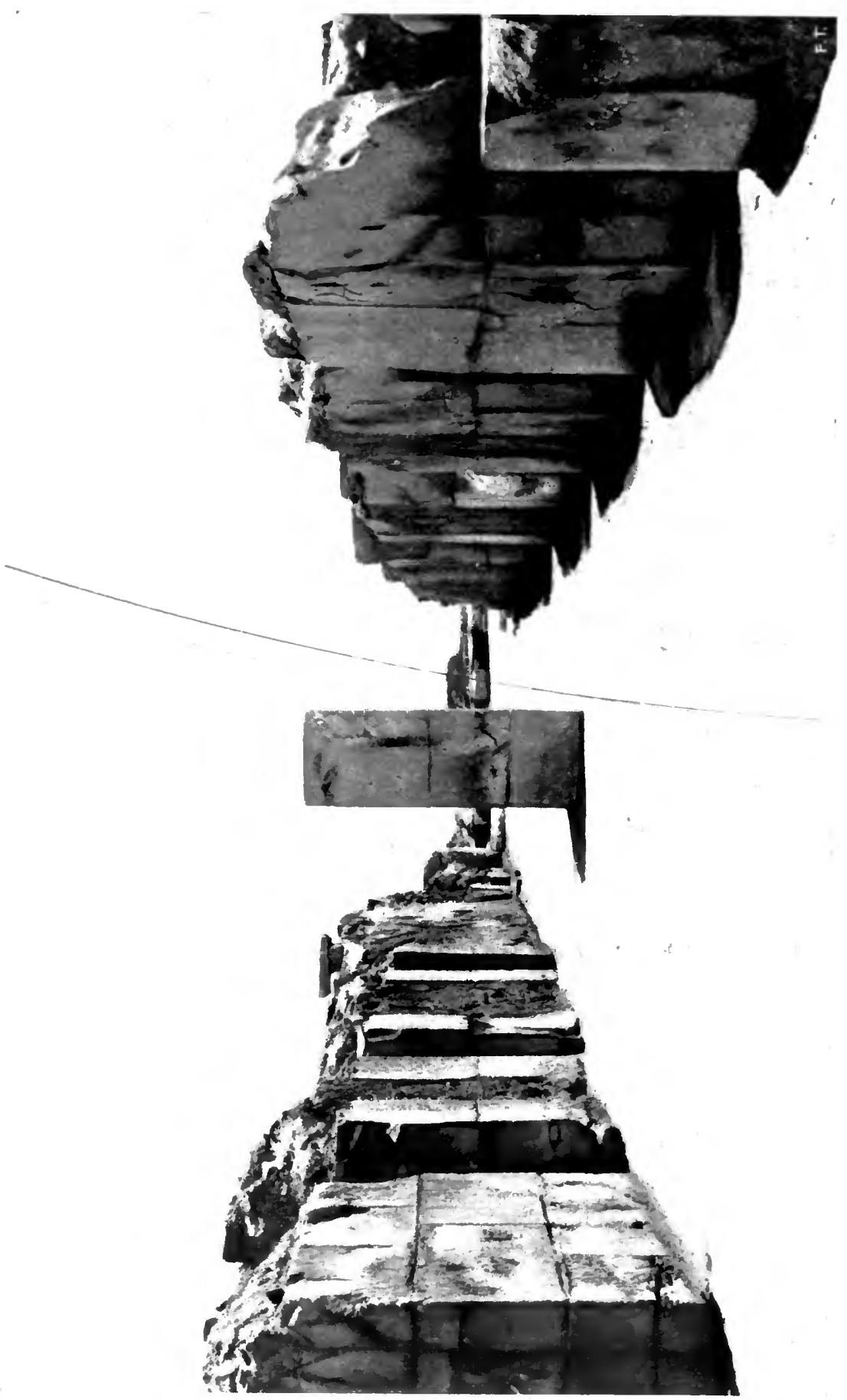

告 

with an incised design imitating fringe, or a pattern was impressed by a stamp.

IX.

The palaces of Phæstos and Knossos are the result of a long period of development which had crystallised the experience of many centuries into a complete system of rules, applied on the two opposite sides of the island in the most minute details.

The uniformity of the Minoan palaces proves that Minoan and Egyptian civilisation developed contemporaneously, and this development was parallel but independent. This is shown in the dimensions of the courts, which are here far more extensive than in the edifices of ancient Egypt. No Egyptian architect ever thought of building the house either of a king or of a private citizen with blocks 3 metres long, I metre high, and 70 centimetres broad, such as we find in these palaces.

The builders of Crete had their own modules, and to prevent the buildings from appearing too plain and monotonous they improved the effect by the use of various projections and embellishments, and by arranging that the whole front should not be on the same plane. Architecture, the most difficult of all the arts, was brought to such perfection that two thousand years later the Greeks and Romans had little to add to it.

Another detail shows the ability of these architects. As they had to make a large number of doors they fitted them all to the walls so that they were not in the way when open, but would fold exactly into the wooden frame which supported the architrave.

In the great court on the eastern side is the base of a portico with basins and benches; opposite is another portico and a great hall with columns. We shall see that at Knossos, too, the number of seats is a characteristic feature.

The origin of the triglyph of the Greek temples appears in the decoration of the benches. Here, too, there are three grooves 
with flat spaces between. The lower part of the benches is covered with a design of squares and spikes carved with absolute accuracy. The bases of the columns are of black marble veined with yellow, others are of red marble veined with white, and the bright polish of these marbles has been perfectly preserved.

The attention of the visitor to the palaces of Knossos and Phæstos is attracted by the slabs of alabaster with which the walls of the rooms are lined. This beautifully veined marble being a costly material for the purpose, the slabs were sawn very thin so that they are often not more than 2 centimetres thick by above a metre in breadth, and the height about that of a man. When the masons had squared a block they marked it, and these marks are seen on all sides in the rooms and corridors-crosses
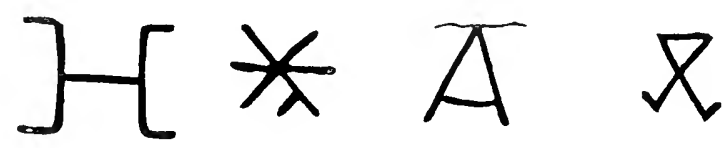

FIG. 22.-MASONS' MARKS ON THE BLOCKS OF THE PALACE OF PHASTOS.

of various form, stars, double axes, small branches, tridents, and other combinations of lines. Nearly all the blocks are marked; some of the marks are shown in Fig. 22. I

\section{$\mathrm{X}$.}

I shall not describe the palace-it is too vast-but will only take the reader to visit a private apartment, of which I give the plan.

The porticoes, which are a characteristic of the courtyards of the Renascence, are here of less majestic type, as the construction of the arch and of the vault was still unknown; nevertheless, the number of these loggias excites our astonishment. Descending

I Dr. Pernier counted each of these marks thirty or forty times on the blocks of the palace of Phastos. 
the hillside. The room designated vestibule is 6 metres square, and has four doors opening under the portico to the north and four more under the eastern portico. This room commands the magnificent view of Mount Ida and the valley.

No finer or more convenient plan for a house on this site could be imagined by a modern architect.

The small size of the sacred monuments is a characteristic of Minoan civilisation. There were at this period in Egypt grand temples like that of Karnac, but in Crete and Mycenæ and in Greece up to the time of Homer there were no real temples. Religion was a private matter; this is a fundamental fact in the prehellenic religions, and only in the Odyssey (in a late intercalation) is a temple of Neptune named. ${ }^{1}$

Mr. Arthur Evans discovered at Knossos, not far from the theatre, a room which he calls a bath-room. ${ }^{2}$ The staircase is made of slabs of gypsum, and a parapet supports the steps. The basin, $2 \frac{1}{2}$ metres square, was 2 metres deep. I was surprised that a bath or basin should be lined with slabs of gypsum, which as we know dissolves in water.3 The bottom is covered with large slabs of alabaster, and there is no trace of escape for the water, although from the nature of the site it would have been easy to arrange a discharge pipe. The existence of a similar basin in the throne-room assures me that this is not a bath.

On the right of the northern entrance to the central court is an antechamber 4 containing a large bath of red marble, and in the throne-room, on the left is a small staircase, also turning at

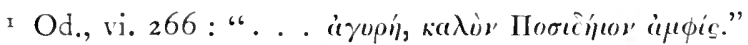

" In Plate I., Plan of Knossos, near the right-hand margin, marked "North Bath."

The slabs are 2 metres high and $1 \cdot 1 ;$ broad. Marble with crystalline granulations and limestone (used with other substances to form lime) are produced by the combination of lime and carbonic acid; the gypsum, now in large crystals, and alabaster are produced by the combination of lime with sulphuric acid. The solubility of marble is one hundred times less than that of alabaster or gypsum.

4 Marked Ante-room on Plate I. of the Plan ; next comes the throne-room, and beside it the tank. A horizontal line drawn from the north bath would pass to the right of the throne-room and tank. 
right angles and leading to the bottom of this so-called basin. To the right on the parapet are three columns, beneath which are the benches which surround the room, and opposite stands the throne.

The suggestion of a bath here is more difficult to uphold, for the idea of undressing and taking a bath in the throne-room itself seems improbable. In the gardens of contemporaneous ligyptian palaces there were tanks for fish and aquatic birds, but in this cas: the stones at the bottom are not cemented together, nor can

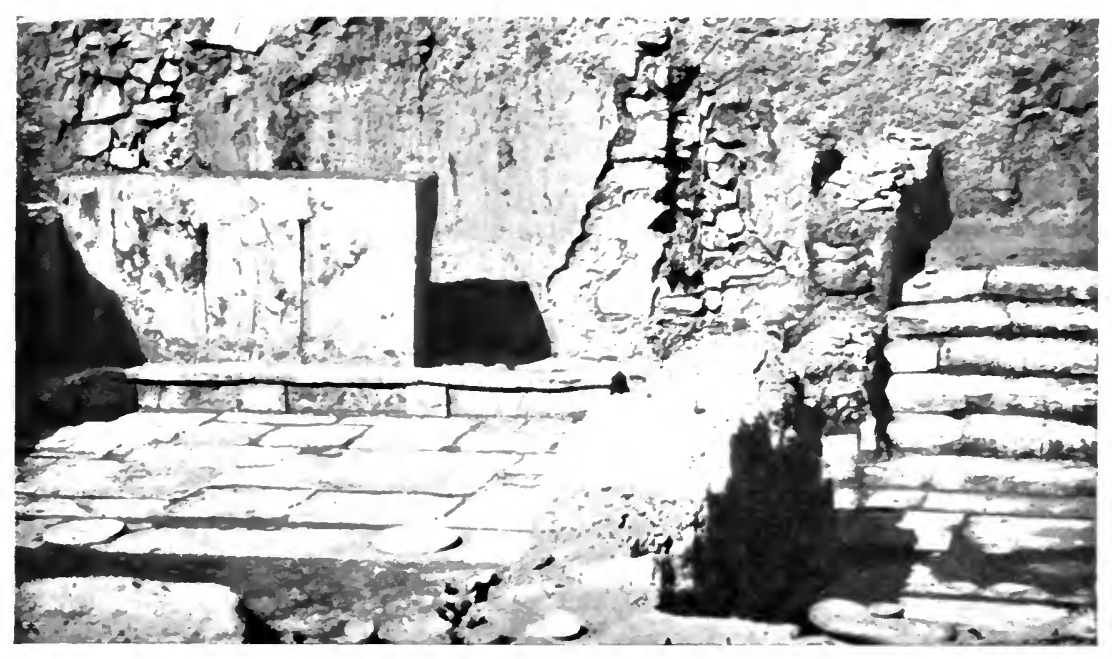

FIG. 24.—STAIRCASE LEADING FROM THE C゙PPER FLOOR TO THE PRIVATE APARTMENTS.

Room to the left marked S.1LA on the plan.

this have served as an impluvium such as we find in Roman houses, for there is a tank carefully built of stone and good cement by these skilful workers of Mycenæan times, who have also left cisterns of equally perfect construction.

Two of these baths are marked on the top left-hand side of Plate II., but in none of them-not even in those which are near the drinking-water pipes and the sewer-is there any sign of arrangement for supply or discharge of water. The fact that a bath tub of terracotta was found in an 
adjacent room also tends indirectly to prove that these were not baths.

\section{XI.}

An examination of one of these baths at Phæstos (Fig. 25) has convinced me that it is a private chapel or sanctuary. A corridor with two turns leads from the vestibule (Fig. 23 to the left) to a room 5 metres square, whence a small staircase leads down into the sanctuary. The dimensions are identical with those of the bath at Knossos; there is the same parapet, and below is the cube on which rested the column and then two steps at right angles; the walls are entirely lined with slabs of alabaster. On the opposite side (Fig. 25), where the shadow is deepest, was a slab of alabaster, which closed the parapet on that side also. Here, too, it would have been quite easy to arrange for the discharge of the water by using a few metres of piping, but nothing of the kind was done. Dr. Pernier, who kindly accompanied me, was convinced that I was right.

The small size of these sanctuaries demonstrates the private nature of Minoan religion. They are not baths but oratories and domestic sanctuaries, and we see here the original form of the cult of the lares and penates which in later times spread to Rome.

There were columns in the throne-room which allowed whatever was in the so-called tank to be seen, and here we find an enclosure-a choir as it were-made expressly to give a view of the sanctuary : such an arrangement would be inexplicable in the case of a bath.

In the pavement of the adjoining room two great rectangles marked with red are still visible, forming a square between the slabs. The cavity surrounded by the alabaster slabs is filled with reddish cement. The alabaster, from its exposure to the weather, has lost the ivory polish and transparency, and has now the grey shade of melted silver. The water which has flowed over it has dried up the azure and roseate veins which had had the effect of arabesques upon a pearl-coloured ground. I grieved to think 
that I was probably one of the last to contemplate the rose-tinted squares of this fine pavement, and I felt both sad and uneasy as I walked upon the slabs, which creaked and splintered as if it were a thin layer of ice upon the marble. Some of the blocks are black as velvet from the action of fire, while others are pure white, and have become like sponge beneath the corroding rain,

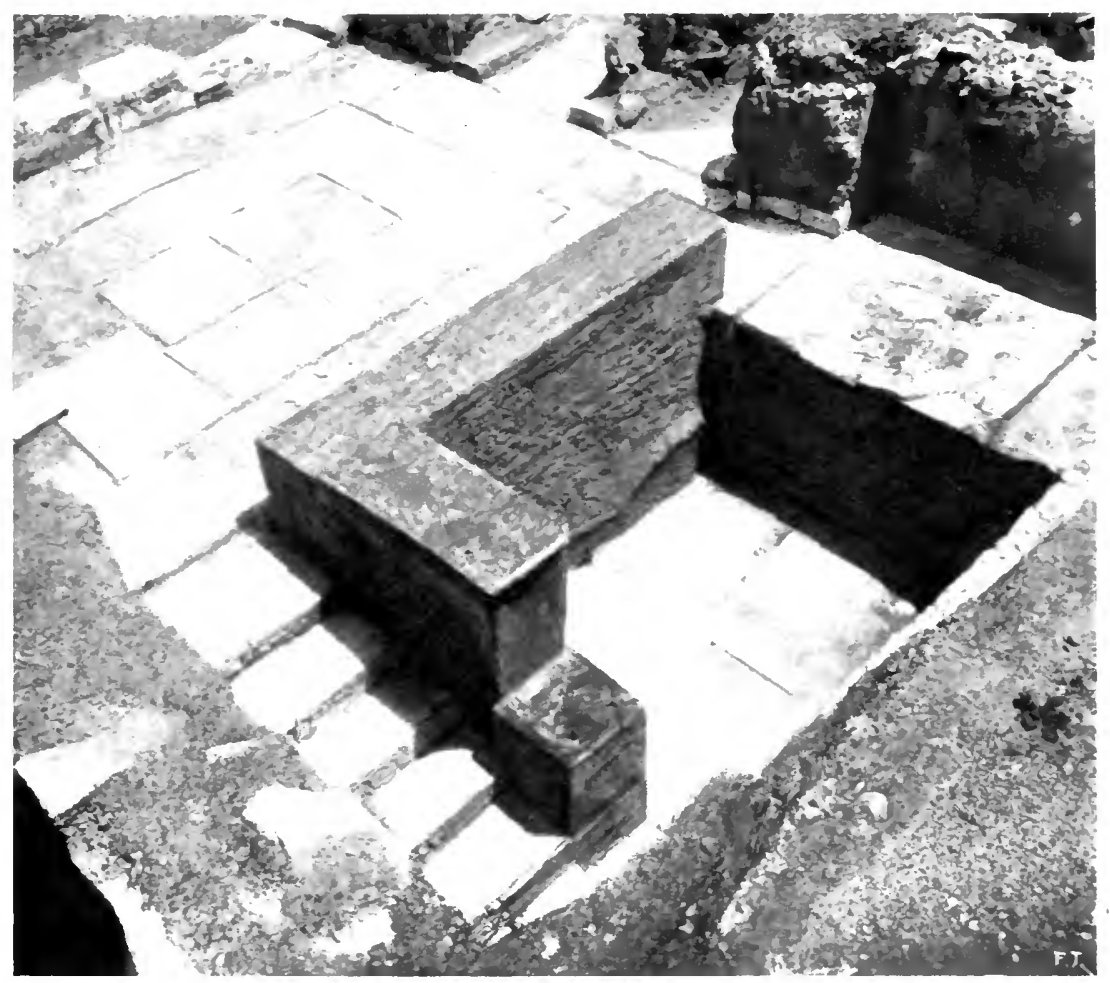

FIC. 25-SANCTLARY IX THE PALACE OF PHASTOS.

giving the effect of snow on ice or of hailstones heaped up in a ditch after a storm.

Within a century the palaces of Phxstos wili exist no longer, and the ruins will only be seen in books. These witnesses of primæval civilisation are inevitably condemned to disappear; everything even to the last vestige will crumble to dust and be dispersed by the wind, or will be dissolved into mud, 
which the rivulets of rain will carry far off to trouble the waters of the river.

In a few years' time nothing will remain but a limestone skeleton; the alabaster stairs will be destroyed, the decoration of the pavements and the incrustation of the walls will have vanished.

In perplexity we watch the ruin of the ruins. The clouds and the sun will devour the sacred relics of that civilisation which was the mother of our own. The vision of these remains brought back to the light has been like a flower which has bloomed unexpectedly to show us the beauty and perfume of pre-Hellenic art-it will disappear sadly, inevitably, but its fragrance, its fruitful germs will last beyond the limits of time. 


\section{CHAPTER III}

A MYCENAEAN VILLA

I.

THIS bronze statuette of a lady of the Mycenæan age was 1 found in the villa of Hagia Triada by the Italian Archæological Mission. The fashionable appearance, the flounced petticoats and tight bodice, give no indication that the lady is about four thousand years old, and the charming profile and carriage resemble those of a lady of the present day. This bronze figure in itself suffices to show how different the pre-Hellenic antiquities are from what we should have imagined.

The villa is entered by the grand flight of steps. The stones of which the walls are built are well squared and joined with mortar, and the steps are as broad and convenient as those of a princely villa of the sixteenth century. It is 2 kilometres distant from the palace of Phæstos, and takes the name of Hagia Triada, ${ }^{\mathrm{I}}$ from a Venetian hamlet close by.

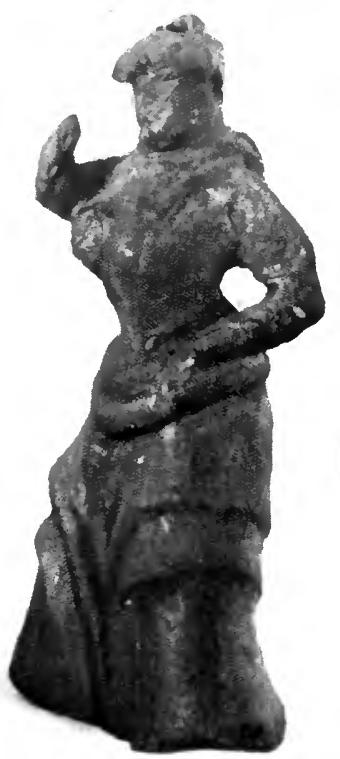

I Hagia Triada $=$ Holy Trinity. F. Halbherr, Rendiconti R. Accad. Lincei, 1905 , vol. xiv. pp. $365-405$.

FIG. 26.-BRONZE: FIGLRE: OF A WOMAN FOCYI) IN THE VILLA OF HAGIA TRIAINA. 
Higher up to the right are the ruins of the Venetian Church of S. George, which was built of stones from the Mycenæan villa. The rampart which supported the raised ground in front of this church had given way, exposing a stratum of archæological detritus which extends to a depth of about 2 metres.

The remains of Mycenæan potsherds and fragments of alabaster found here led to the discovery of the villa by Professor

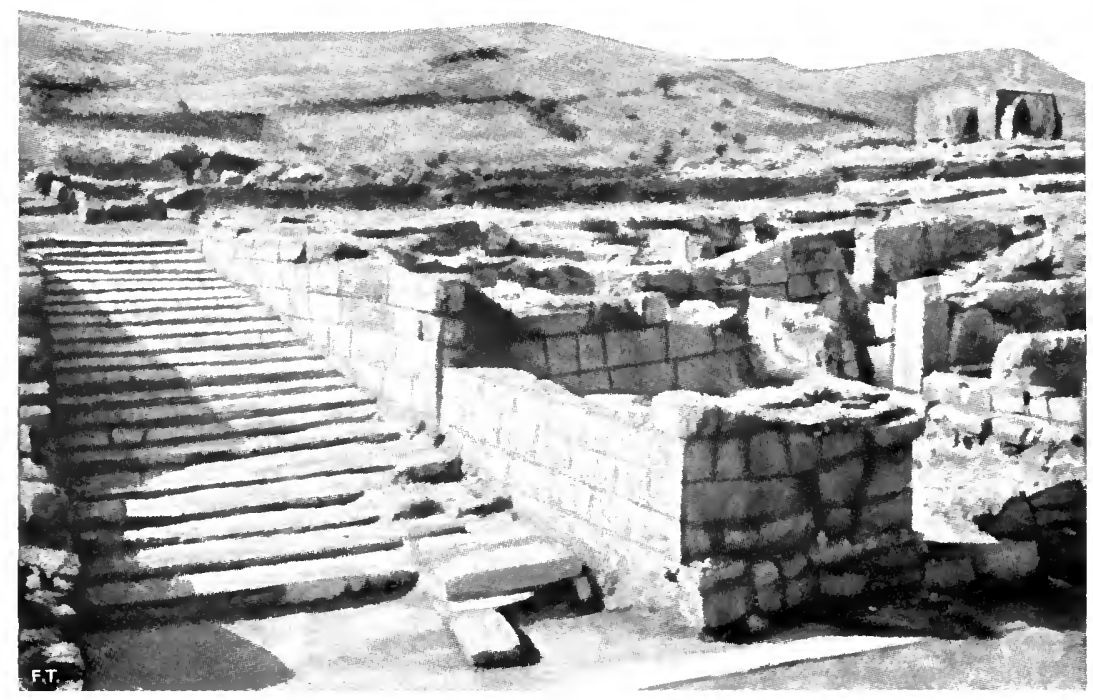

JIG. 27.-FLIGHT OF STEPS OF THI: VILLA OF HAGIA TRIAINA.

Halbherr. Round it was a small village with several better class houses built of large blocks of stone, with a portico and vast magazines ${ }^{\mathrm{I}}$

I Professor Halbherr's excavations show that the stratum of the Kamares vases extends beneath nearly the whole of the original palace at Hagia Triada, and that some parts of the most ancient edifice were rebuilt and included in the later building. These facts are of importance in fixing the chronology of this villa in connection with that of the palaces of Phastos and Knossos, with which it is contemporaneous. 'The alterations which it has gone through are described in the "Relazioni," R. Paribeni, Rendiconti R. Accad. Lincei, 1903, p. 317. 
II.

Only one single manuscript was found in the palace of Phrstos, but in the villa a hundred and fifty have been discovered. I call them manuscripts, but this designation may seem incorrect, for they are small tablets of clay on which characters and numbers have been incised with a pointed instrument while the clay was still soft. This was afterwards hardened by fire, and small tablets formed similar to those shown in Fig. $28 a$ and $b$.

When we speak of manuscript we are so much accustomed to think of paper or parchment that the wax tablets on which the Romans wrote with a stylus and these of clay hardly seem to us to be manuscript, but the characters of which I am speaking belong to the archaic type of writing which was in use before that in common use in the later palace of Knossos. Unfortunately up to this time the writing has not been deciphered, and nothing is understood except the numerals, which appear to be used on the decimal

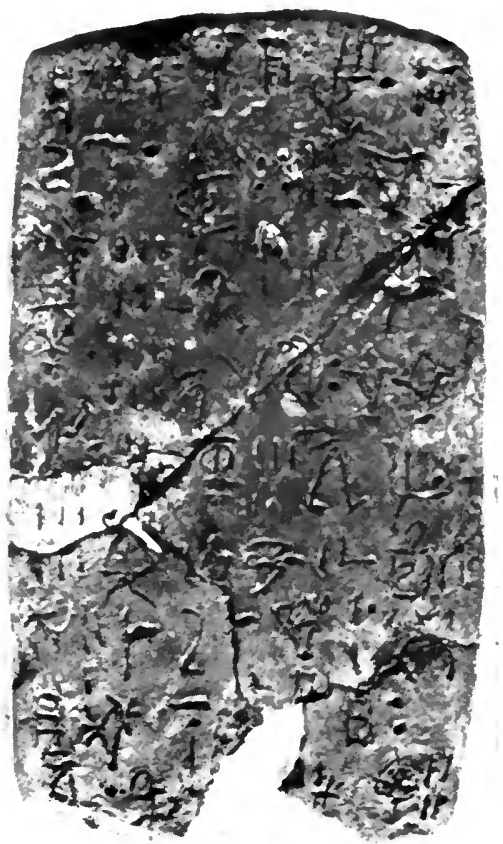

FlG. 28a-INSCRIBE1) TERRACOTTA TABLET FOCNI IN THE VILLA OF HAGIA TRIADA. system.

The units are marked by vertical lines, the tens by horizontal lines, a hundred by a cross within a circle. As the tablets of Fig. $28 a, b$ are difficult to make out, one being broken into several pieces, I give a sketch of two other tablets (Fig. 29a, b), in which the writing is clearly shown.

The two first signs on the tablet 296 show the open hand and a bird flying. The last signs on the same line resemble those 
marked on the back of the faience plaques for inlaying on furniture which were found in I906 at Phæstos, proving that the workmen could write. Other signs are identical with those incised on the blocks in the walls. The prevalence of numerais on these tablets suggests that they were accounts. In some of the lines the heads of animals are indicated by a circle with eves and horns; other tablets have the design of saffron flowers (used for dyeing stuffs yellow), of arrows, and of chariots.

The tablets discovered in this villa and those found at Knossos by Dr. Evans form a small library, for there are more than two thousand, and the time when the primitive history of Greece shall be read from them is eagerly expected. The most ancient tablets

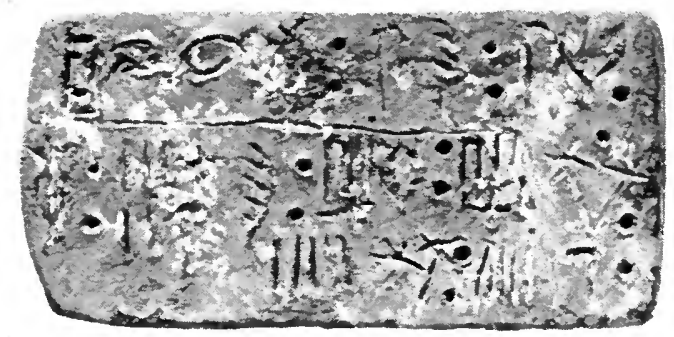

FIG. 28b.-INSCRIBED TERRACOTTA TABLET FOCND IX THE PALACE OF PHASTOS.

contain pictographic characters, and this pictographic script has gradually developed into the linear and geometrical characters which served later as the foundation of the Phœnician alphabet.

The terracotta tablets were not the only material used for writing. There are characters in black on some of the utensils written with a brush dipped in sepia; possibly palm-leaves also were used for the purpose, but terracotta tablets were preferred for writing anything like receipts or contracts which were to be preserved unaltered. Dr. Evans gave the name of schoolroom to a chamber which contained receptacles in which the clay was kept soft.

The wax tablets of the Greeks and Romans were lighter, but were more easily spoilt than those of terracotta. Some of the 
tablets have kept the imprint of fingers, and it is possible to study the design of concentric whorls left by those finger-tips. One small impression must have been left by the finger of a woman. The thing interested me in connection with female education, but I thought it might have been the cook who took the damp tablet from her master, and put it on the fire to harden.

It was from the Minoan script transformed by the Phonicians that the modern alphabet was derived. Diodorus Siculus ${ }^{1}$ says :

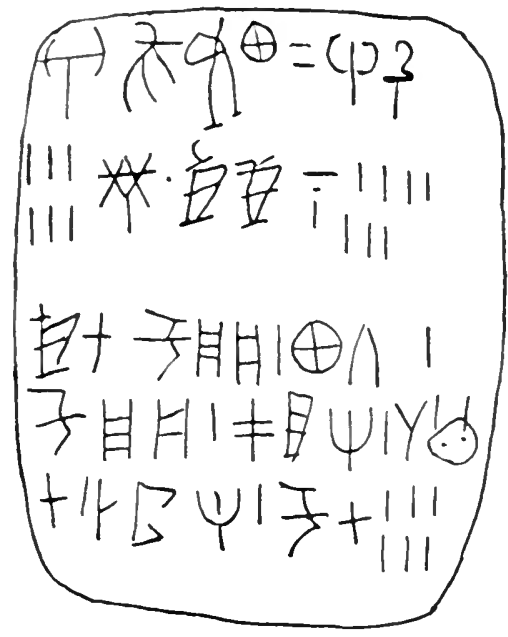

FlG. 29 ar.

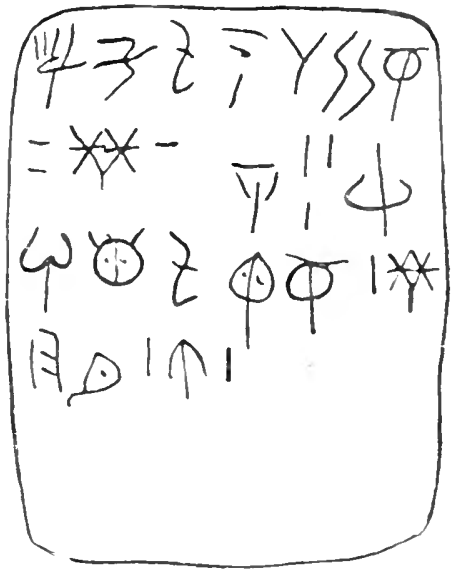

FIG. 29 b.

TABLETS WITH WRITING FOCND IN THE VLLA OF HAGIA TRIAIA.

"Some pretend that the Syrians were the inventors of letters, and that the Phœnicians learnt from the Syrians and brought the art of writing to Greece, whence the name of Phonician alphabet. But the Cretans say that the first discovery came not from Phœnicia, but from Crete, and that the Phœnicians only changed the type of the letters, and made the knowledge of them more general among the peoples."

The first writings of the Phœnicians appeared about 1000 or I 100 в.с., while the Mycenæan linear script was already in use

$$
\text { I } V .7+, \mathrm{I} \text {. }
$$


in I 900 B.c. I In Homer there is only one confused mention of writing, though it was common among the Mycenæan people, and scratched inscriptions were found on the walls of the palaces. When the wife of Prætus wished to have Bellerophon put to death 2 "she sent him to Lycia as bearer of closed writing to her father-in-law the king that he should make him perish."

\section{1.}

Seals were in constant use, and a method similar to that now used for sealing parcels and railway vans was commonly employed

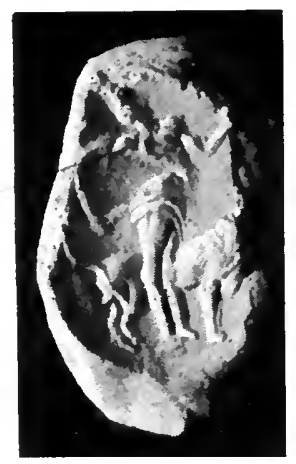

FIG. $30 a$.

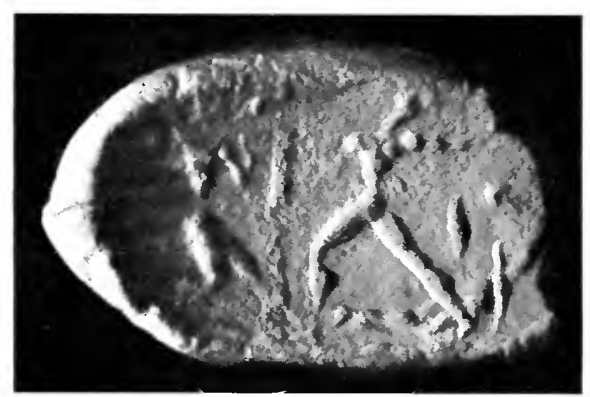

FIG. $30 b$.

SEALS.

for closing writings. The fastening was covered over with a lump of plain clay, within which was the twine of vegetable fibre or papyrus, and an imprint, or generally two, were made upon the clay. This method of sealing was so common that in one single pit 450 seal impressions were found made by a ring. 3

The seals were of gold, cornelian, or rock crystal, but the

I Evans, "Further Discoveries," London, 1898.

"Iliad vi. I68. Writing is not mentioned in the Odyssey, though that

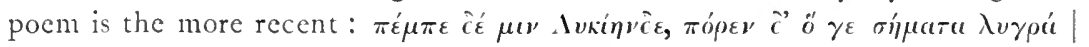

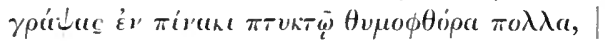

3 Halbherr, "Monumenti," xiii. p. 39, 1903. L. Savignoni, "Resti dell' età micenea scoperti ad Hagia Triada," Monumenti $R$. Accad. dei Lincti, vol. xiii., 1903 . 
most ancient were made also in wood, steatite, or ivory. In the frescoes men are seen wearing a bracelet on the wrist with one of these intaglios, and even at the present day the Pashas and all orientals sign by a seal or with a stamp.

I give here some of the devices of seals found at Hagia Triada to show the beauty of the intaglios and the vivacious and elegant attitudes of the figures, choosing those designs which show us family life, games, and feminine attire, to which I shall devote a further study in following chapters. In the first (Fig. 30a) a man with a bow is standing by a lion. As lions no longer existed in Crete at this time, the design is possibly a record of a journey into Africa whence ivory was imported. The second

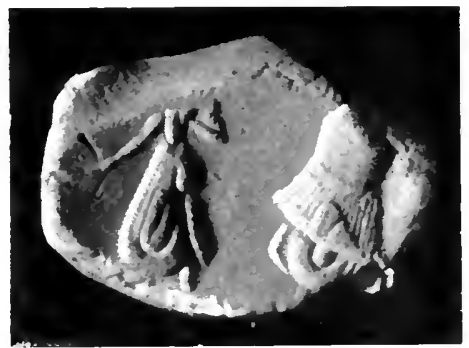

FIG. $3 \mathrm{I} a$.

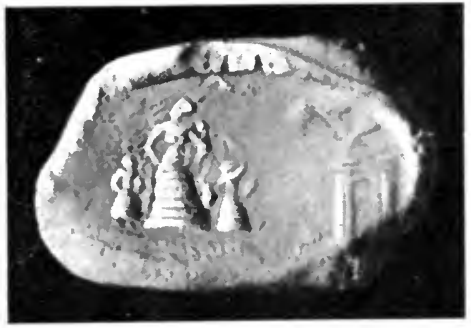

FIG. 3 I b.

SliALS.

(Fig. b), taken from the intaglio in a large, much worn bezel, represents a fight between three nude men armed with spears, with a column in the centre. One of the men is wounded and about to fall. On the right is another man lying on the ground, seen indistinctly. In Fig. 3 I $a$ the first figure is a woman, the second a warrior with cuirass and shield. The seal (b) represents a mother with two children, a sacred tree, and the columns of a small temple.

The cast (Fig. 32a) represents three women playing a game. Two are dressed in puffed-oilt petticoats like the woman in Fig. 3Ia. The woman playing at ball in the middle wears a pair of trousers with horizontal puffings. I quote Professor Halbherr's description of the seals (Fig. $32 a$ and $b$ ): "Woman 
with the bosom apparently nude, the waist tightly belted in, and wearing trousers with parallel puffings. On her head she wears a small conical hat surrounded by a turban. She is represented in the act of dancing and playing with two balls between two girls or women with puffed-out dresses holding wands in their hands." Fig. $32 b$ shows a real fashion plate of the Mycenæan age. Two very fashionable ladies advance with measured movements, possibly towards a temple. "The chest held well forward, with the breasts drooping, the bell-shaped skirt with trimmings of flounce or fringe, the curves of the figure, the tight waistband give the costume and attitude of these figures that characteristic appearance

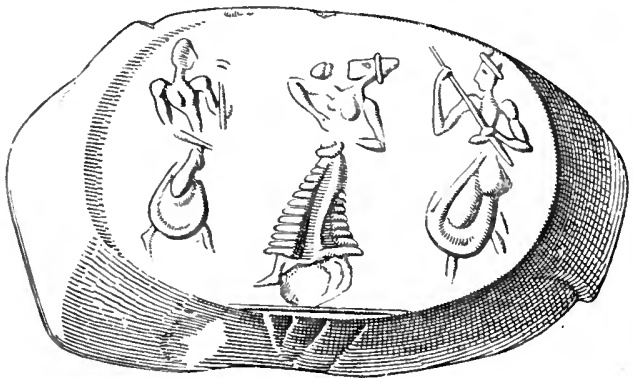

FIG. $32 a$.

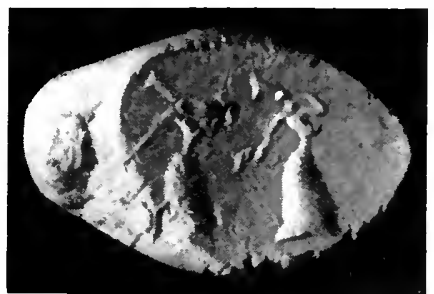

FIG. $32 b$.

SEALS.

produced by the refouleur corset of the latest Paris fashion. Here, however, the bust appears to be nude, as in the women of the preceding seal and most of the others, or if this is not the case, we must suppose that this appearance of nudity is given by a very fine and closely fitting chyton, like the onion skin of Odysseus."

The most celebrated works of Mycenæan art were found in this villa. They are vases of steatite with figures in relief, which were covered with gold leaf. The design of one cup discovered by Professor Halbherr represents an officer giving an order to a soldier. The realism of both the figures makes them admirable. The severe and martial attitude of the officer, who holds a lance, the rigid position at attention with the feet together, and a certain air of tension in the private with his sword, are expressed with 
surprising truth. Militarism has eridently the same attitudes and expressions in every age.

Whoever sacked the palace removed from the cup the gold coating which gave it the appearance of solid gold. This cup, with the marvellous finish of the work, is one of the most

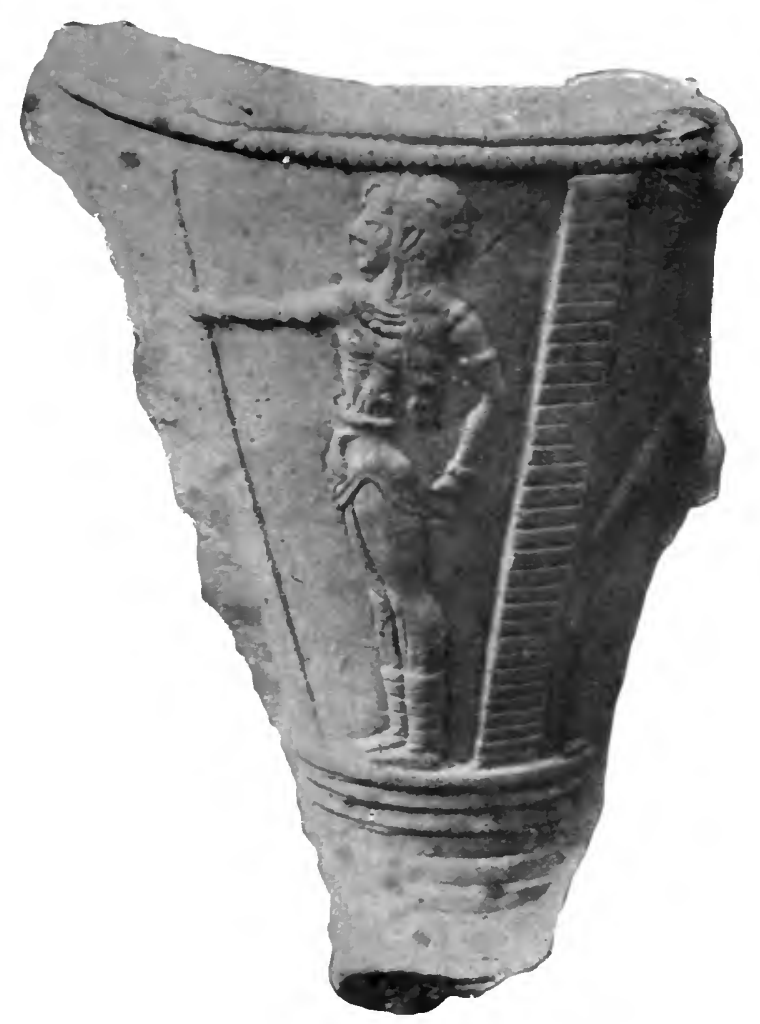

FIG. 33.-TASE IDSCOVEREL AT HAGIA TRIADA IB' PROF. F. HAL,BHERR.

exquisite pieces of sculpture which have come down to us from the Mycenæan age.

\section{IV.}

The hill upon which the villa stands is about 50 metres high, and the sea was once at the foot of the slope, but during the fifty centuries and more which have elapsed since then, the 
shallow bay has silted up and the plain which now lies before the villa has been formed. The Old River, or Geros Potamos as the Greeks called it, flows through the gorge which forms the entrance of the valley of Messarà, and at one time fell into the sea near the villa; now, however, the mouth of the river is 5 or 6 kilometres distant.

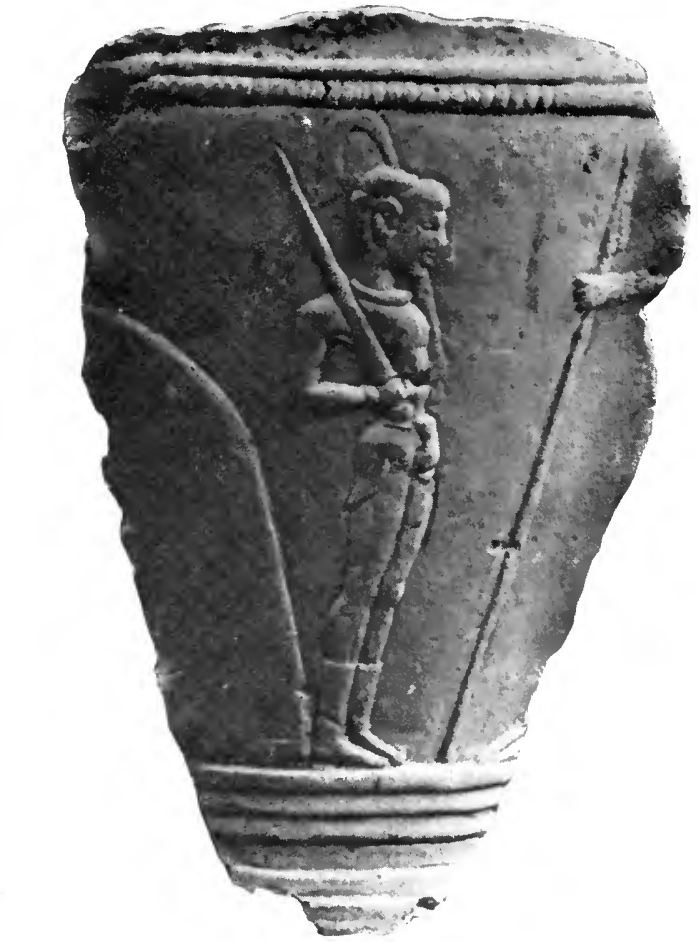

IIG. 34.- VASE DISCOVEREI) AT HAGIA TRIADA IY PROF. F. HALBHERR.

I explored the plain as far as the sea and found that it consists of pebbles and detritus carried down from the mountains by the water. Besides the river Geros Potamos another torrent, the Majeros, flows from Mount Ida. The Islands of Letoe lie opposite not far from the shore, and in old times there must have been another island where, on a small eminence rising from the plain, the embarcation office now stands. This theory of 
mine will be proved when fresh excavations along the old road to the villa bring to light the ancient constructions which probably exist beneath the valley which was once a Mycenaan port. The original bay has been partly filled up by the detritus brought down from the slopes of the highest mountain in Crete, where Ida rises to 2500 metres.

Greece and the Greek Isiands are among the most sterile countries in Europe. The steeper the mountain sides are, the more picturesque and varied, the more rapidly is the ground corroded by the water and the vegetation scantier in proportion. The torrential rains, thus unimpeded by obstacles, wear away the soil and rock of the bare mountain side. The waters of the torrents are more turbid and fill up the valley of the river delta all the more quickly with the earth and stones which they roll down.

Along the course of the Geros Potamos grow planes and large bushes of golden broom, which spread like a garland down the bank on to the gravelly soil. Other bushes in the distance resemble the rhododendrons on the Alps; they are oleanders with fine leaves and are covered with rose-coloured flowers.

Phæstos was the maritime rival of Knossos, but now the surrounding plain as far as Dibaki is infected with malaria. It cannot have been so formerly, as the villa was on the sea; it would not otherwise have been built upon so low a site.

In the village of Voris, not far from Hagia Triada, I saw a sick man lying in the sun shaking with the rigors of the fever. I dismounted to examine him. His skin was of the same earthy colour as patients whose blood is affected by malaria. The heat was stifling, but it was with great difficulty that I was able to persuade him to let himself be carried to the shelter of a carob tree to save him from sunstroke. 
V.

It would be more correct to term Hagia Triada a commercial emporium or the port of the City of Phæstos, rather than a villa. Certain marble pedestals which are foreign both in design and material, also some perfect vases, and fragments of vases of alabaster from Egypt, form a record of the trade of Crete with Egypt. Here, too, there are traces of fire on all sides, and we pass from a room with a pavement of dazzling whiteness to another where the stones have been burnt black. Along the alabaster staircase the bases of the columns still remain placed on great square blocks with beautiful veinings, and the shining white steps give the severe impression of a mausoleum which has been opened after an interval of four thousand years. What a contrast to the busy life of long ago! The masters of these palaces were such active folk that we should search in vain for their like in other lands.

After the fire the villa was deserted for a time. We know this, for Professor Halbherr found a stock of large pieces of pure copper weighing about 30 kilogrammes each. ${ }^{\text {I }}$ The fact of nineteen such large pieces of copper having been forgotten proves that when the villa was being rebuilt there was no one left who could remember where to seek for the stores of metal among the ruins.

The new edifice was built with stronger walls-in some parts they are a metre and a half thick-and the apartments were differently planned. Limestone was used instead of gypsum, of which the original palace was chiefly constructed. The sewers seem to be larger than in the other palaces of Crete, and one day, after a heavy downpour of rain, I was interested to find that all the drains acted perfectly, and I saw the water flow from sewers through which a man could walk upright. I doubt if there is any other instance of a drainage system acting after four thousand years.

I I will publish the chemical analysis of this copper in a study of the bronzes of Crete. 


\section{V'I.}

Large windows are a characteristic of Mycenaan architecture." One is shown in Fig. 35 above the alabaster seat. The building being against a hill, the architect supplied light by means of a court of the same type as that which we saw in the private apartment at Phastos. The window frames were of wood. There are no windows so large in Egypt or in any

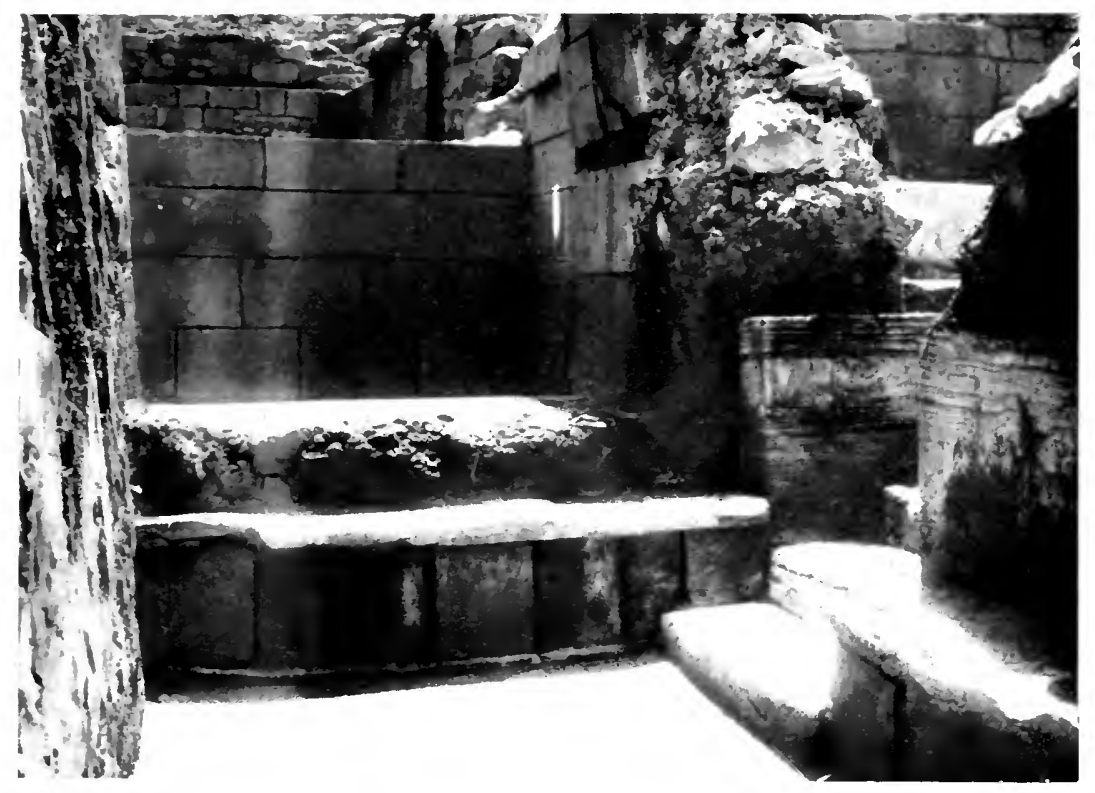

FIG. 35.- WINIOW ANI) SEAT WITH ALABASTER MLOCKS NEAR THE STAIRCASE IX THE VILIA OF IIAGIA TRIAIA.

Oriental country, and this fact should be noted in studying the originality of Mycenæan architecture. Three steps on the right mark the beginning of the staircase, which was on the upper floor. The great blocks of alabaster served as bases for the wooden pillars.

Three stone lamps were found in a room with benches against the walls. Two lamps were near the door and one near the

I I measured three windows which were $1.70 \mathrm{~m}$. to $1.80 \mathrm{~m}$. in width. 
bench. Probably all the inhabitants fled at the time of the catastrophe, leaving everything where it was, and the position of the lamps suggests a supper or the usual occupations of the night.

The room is handsomely decorated and the walls are faced with large slabs of alabaster; between the slabs were connecting bands or borders of wood. The stone benches placed round the room are richly carved out of large blocks of alabaster with

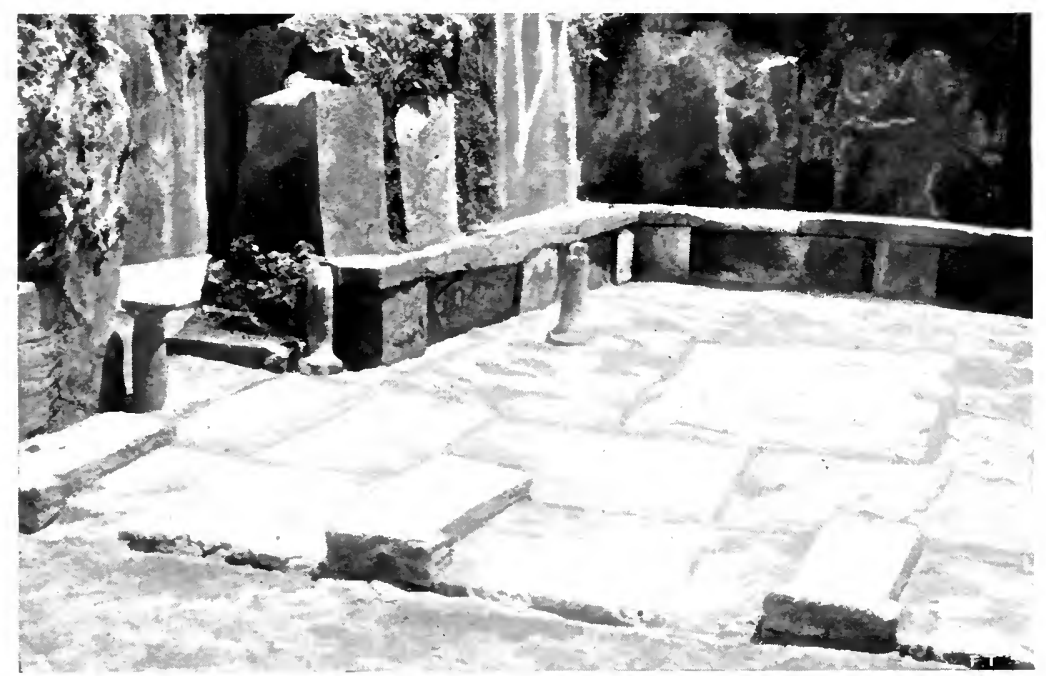

FIG. 36.-ROOM WITH SEATS ROLND, AND THREE STONE LAMPS LEFT IN PLACE AS FOUND.

On the left, entrance of sleeping-room. In front, alabaster bases of the door-posts, which were fitted with wooden doors.

beautiful veinings. The sockets and all the joinings are well finished. On the pavement we still see the concentric rectangles filled with stucco once coloured red, as at Phæstos. The ruins might be those of a temple rather than a house! The surface of the stone has now become tarnished, porous and opaque, but when the alabaster had all its lustre and the woodwork its polish, and the strange arabesques of rosy, yellow and blue veinings gave the effect of a relief, this room must have been unsurpassed in the beauty of its decoration by the most splendid that can be found 
in the palace of a prince. 'The Romans never understood comfort in a house. A visit to the houses of Germanicus and Livia on the Palatine suffice to show that in spite of the profusion of frescoes they were scantily supplied with light and air. The adjoining room is a bedroom, for there is a slab of alabaster 2 metres in length and $\mathrm{I}$ in breadth raised 6 centimetres above the floor, which is also of alabaster. One corner of this room is seen in Fig. 36, behind the lamp to the left, which perhaps still stands where it was when the fire broke out. The walls of the sleeping-room are magnificently panelled with alabaster, and to give variety to the colouring a red marble or green serpentine have been used for the bases of the columns.

\section{VII.}

"Voris, May i j, 1906.

"It has been raining all the afternoon, and I took refuge in the little church of S. George. An inscription over the door says that the chapel was built and decorated by two nuns in 1302 .

"The interior of the old church is covered with frescoes, and the smoke of the lamps and candles has spread a dark veil over the walls, through which gleam the gilded aureoles of the Byzantine figures. Except in the paintings on the ceiling, all the saints are minus their eyes. In the apse the Madonna, wrapped in a large blue mantle edged with gold, and the Child are both eyeless. The majestic figure of the Saviour, too, with His shining aureole and the Cross, and S. George and S. Basil, have all received the same insult from the Vandals who have removed their eyes. On the iconostase S. Christopher and the Evangelists have all been blinded. On the smoky tones of the ancient frescoes, on the dull brown of the shadows of the church, these white spots where the plaster is exposed and the marks where the eyes have been scratched out on the yellow of the sacred icons, give the effect of a place of torture. I imagined that it was an insult offered under the dominion of the Turks, 
but my guide knew that even at the present day Christians thus injure the images in the churches and that in many others the saints are eyeless. When a girl is in love and her affection is not returned, she goes to a witch and begs for her assistance. At midnight the old woman accompanies the girl to the door of the church. Here she disrobes and enters the church nude, carrying a sacred candle; after praying she scrapes the wall with a knife

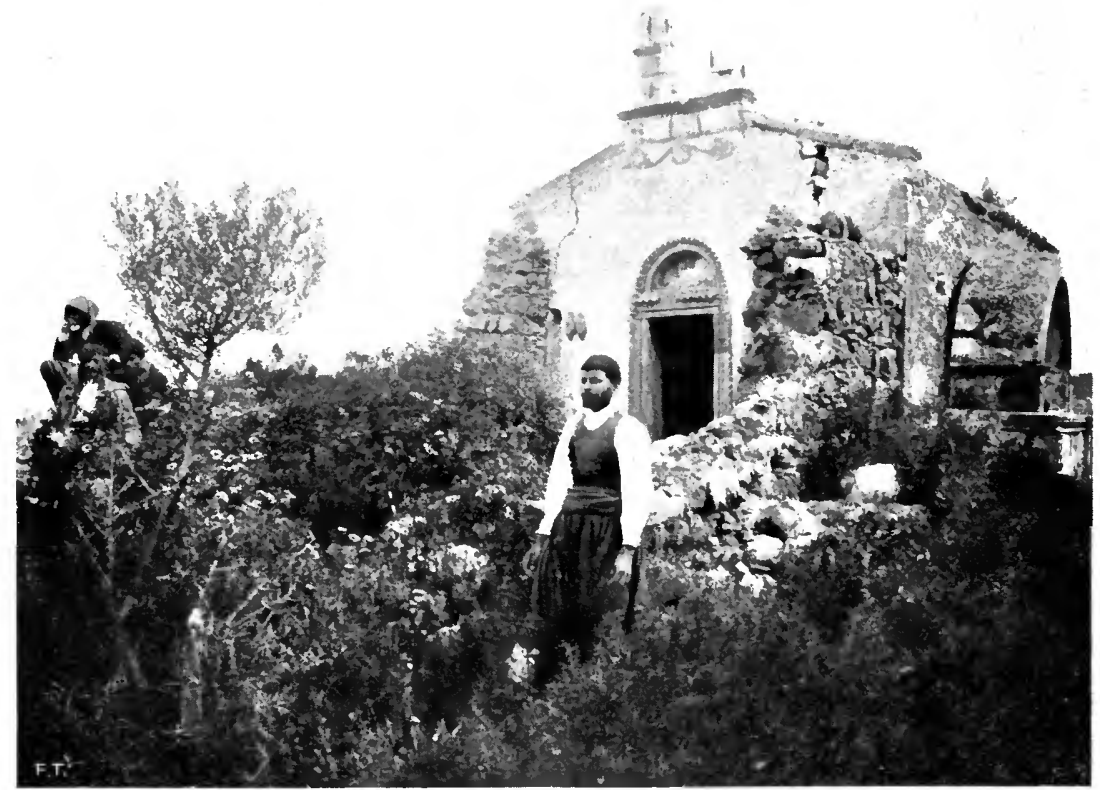

FIG. 37.-CHURCH OF S. GEORGE IN THE VILLA OF HAGIA TRIADA.

where the eyes of a saint are, collects the plaster in a piece of paper, ties it up in a rag, and presently throws it through the window into the house of the loved one."

VIII.

In Mycenæan times the women of Crete wore necklaces of lozenge-shaped beads of gold alternating with drops or crouching 


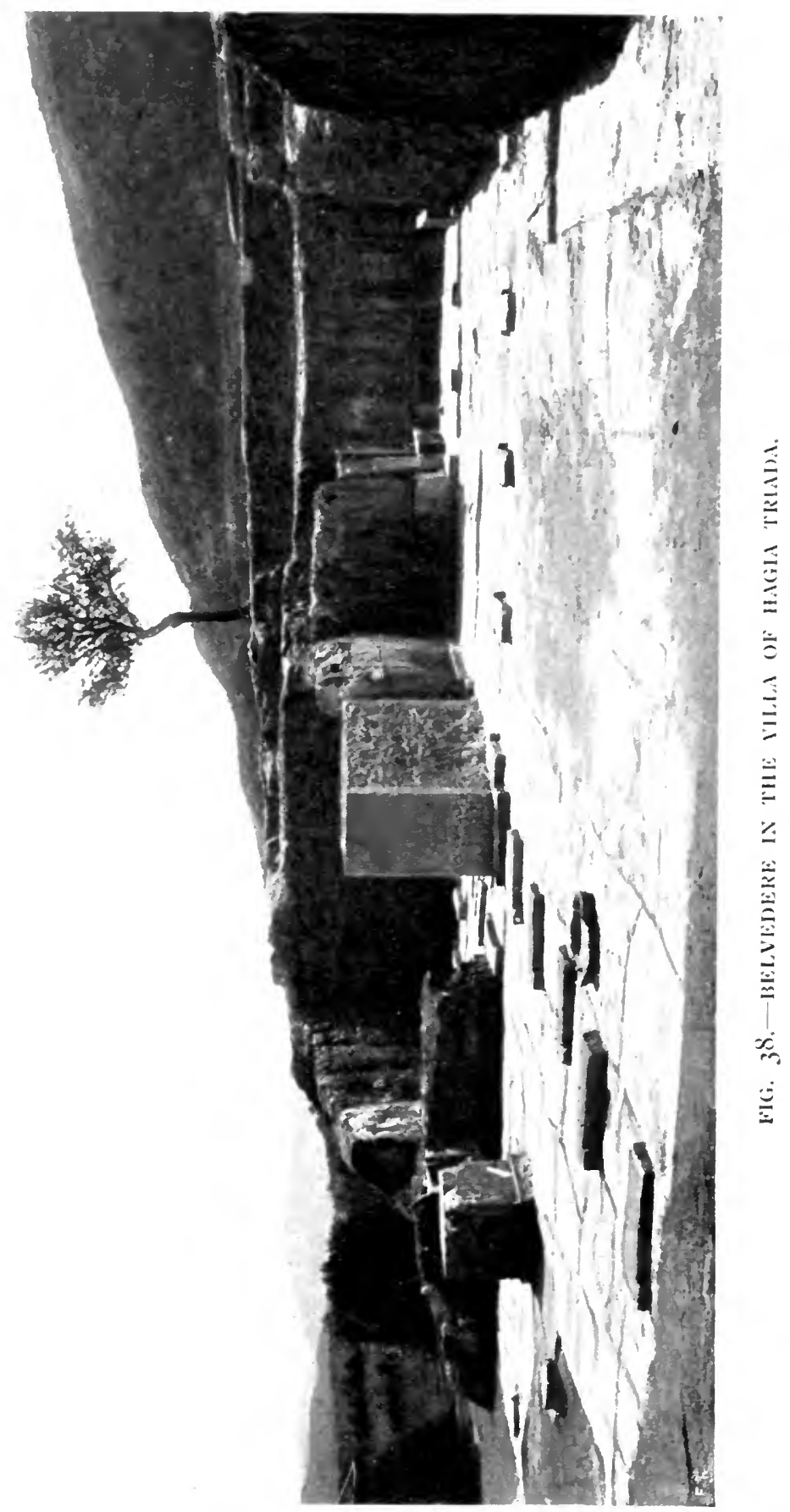



lions; the clasps were calves' heads made with exquisite artistic skill.' On the wrist and below the shoulder bracelets were worn, formed of gold bands wound round in a spiral. The title of Belvedere was given by the discoverers to a part of the villa where there is a terrace facing the sea (Fig. 38). Little is left of the building but the pavement and some walls, on which are the frescoes, of which I give a specimen in Fig. 39.

I do not know to what genus of plants the flowers and

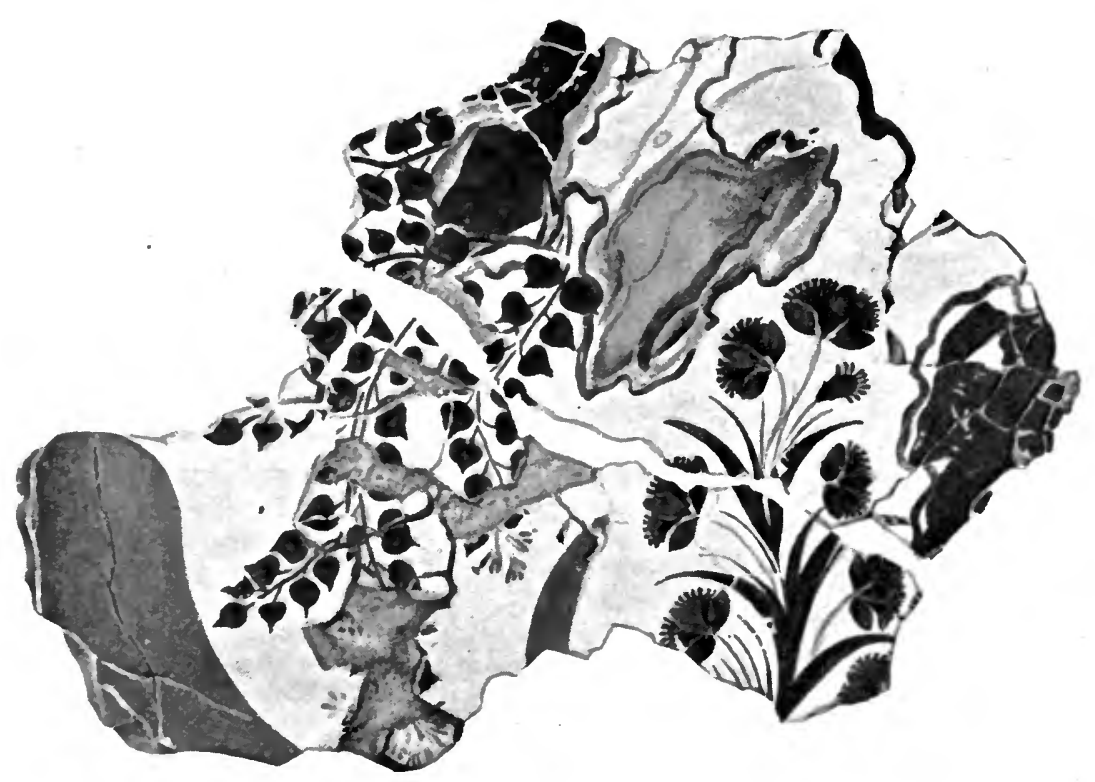

FIG. 39.-FRESCO IN THE VILLA OF HAGIA TRIADA.

leaves here drawn belong, but think they must be imaginary. The flowers at the end of the spray of leaves are not those

r Ornaments of this kind were found in a tomb at Hagia Triada by Professor Halbherr, who found also an Egyptian seal bearing the name or Queen Tyi, who lived in $\mathrm{I}+30$ B.c. She was not of royal blood, and Amenhotep III., who had married her for love, had her name engraved as often as possible on scarabs, of which there are many in museums, and one was found at Mycenæ (v. Bérard, "Les Pheniciens et l'Odyssée," Paris, I903, vol. ii. p. 596). By this we can date the tomb. 
of the ivy, and I have never seen the long leaves of the plant on the right with such flowers. The room with the three lamps is to the right at the back of Fig. 38 , and on the first floor is the pavement of a great hall surrounded by a portico; the base of the walls is seen to the left, also the openings of the doors, of which there were six on the left side and four in the wall near the room of the lamps.

Imagine a scene like that in the painting at Resina which was covered by the lava of Vesuvius. Two girls crouch on the

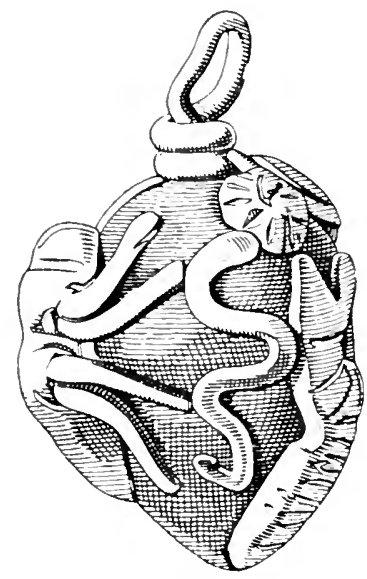

FIG. +O.-GOLD PENDANT FOCNI IA THE VILLA, OF HAGIA TRIADA.

Drawn five times larger than the original. ground playing with astragali beneath the portico of the belvedere. They wear fine red and white embroidered garments with a broad Greek key pattern at the edge of the skirts. Feet and arms are bare, except for the bracelets on wrist and upper arm; they have thrown up the astragali and are catching them on the back of the hand and fingers. The lilies in the vases around give an air of virginal purity to this picture.

The sea shines like a sheet of silver, and on the beach stands a row of blue and red prows. The mountains above as far as the peak of Ida are steely blue. The setting sun dyes the clouds purple with his last rays. One of the girls wears a heart-shaped pendant no larger than a pea on her gold necklace. Fig. 40 shows this five times larger than the original. The goldsmith has covered it with designs of animals in relief, a scorpion, a spider, and a serpent. From this pendant we learn that at that time the heart was already looked on as the emblem of the passions. He who figured these symbols round the heart, suggesting to the goldsmith a language which is to us mysterious, he who enfolded the centre of life with these signs and gave the souvenir to a woman, expressed a thought and affection which 
after the lapse of centuries rouse us to listen to the eternal language of love.

IX.

At the villa of Hagia Iriada it is possible to obtain some knowledge of the commerce of the Mycenæan age through the trade in bronzes and pottery carried on by the princes in their seafaring expeditions.

When Telemachus arrives at Pylos with his comrades, Nestor and his sons come to meet him, invite him to a state dinner, and after dinner, when with food and wine they have "warmed and cheered the heart," they ask him ${ }^{1}$ : "Strangers, who are ye? Come ye to trade or journey ye as corsairs?"

At that time the occupation of corsair was a kind of sport much in vogue at the courts of princes. Odysseus in the assembly of the Pheakians relates how after he had sailed from Troy the wind took him to the Cicones, where he sacked a town, slew the men, and carried off the women and a great

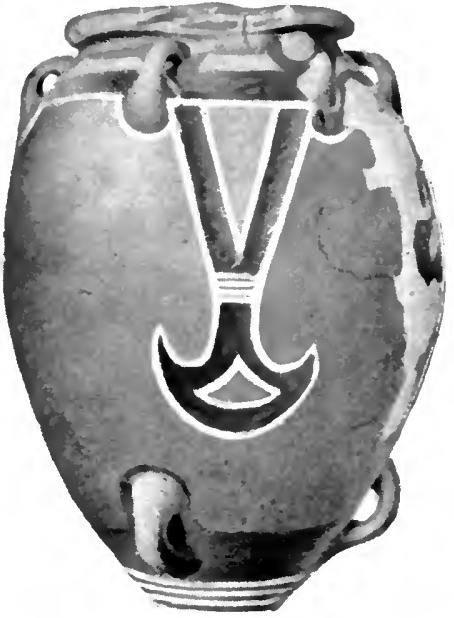

FIG. $f$ I. - KAMARES VASE FOLND IN THE MOST ANCIENT PALACE AT PHASTOS. quantity of goods, which were divided among the crew, so that no one had reason to be dissatisfied. Such was the life of these princes, but the Cretans were certainly less given to robbery. The extension of their dominion on the sea held them within bounds. Thucydides and Herodotus agree that the suppression of piracy and the supremacy of the Cretans in the Mediterranean were the work of Minos, and from that time dates the proverb, "Cretensis mare ignorat."

In the porcelain factory a great stone was found. Upon this

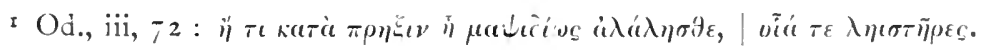


stone, which was slightly inclined, the clay was perhaps mixed and the potter's wheel stood. In the corners are the receptacles for water or colours. The fact that this room, too, was lined with slabs of stone gives the impression that some work which might soil the walls was carried on there. Close by was a room full of vases, which had all been broken when the ceiling fell in. The sherds formed a layer more than a metre in depth.

All round this room there were wooden shelves as in a shop, and the rows of holes into which the wood of the brackets had fitted are visible. The pottery of Hagia Triada is painted in designs of spirals or of branches drawn obliquely across the body of the amphoræ; other vases have polychrome decoration of knobs and twists in relief. The objects of bronze found in this villa are more numerous than all the bronzes found up to this time in the rest of the island.

$\mathrm{X}$.

(After the Last Visit to Hagia Triada.)

"Voris, May 30, I 906.

"I have been lying in the shade reading a book of the Odyssey, and I thought of the pierced beds of Homer, the purple coverlets, the fur cloaks, and the carpets which had once covered the alabaster couch on which I lay. Then I walked through the rooms, looking for pieces of painted plaster. The motives most frequently used in the decoration of the walls are lines in red combined with lozenges, which are carried round the squares and interlaced in the centres of the walls. Leaves or branches, too, are boldly drawn with the brush in grey or red on the yellowish background. I noticed a small blue flower with the centre of the corolla indicated by a circle in red with a white dot in the middle, and round it an olive leaf. The blue-veined alabaster has a milky opalescence. Above the cutting the flowers of the wild salvia and tufts of wild mint recalled the gardens of long ago and the 
slender white hand of the woman gathering a crocus flower on a fragment of fresco.

"The olive trees shade the slope of the hill below as far as the Geros Potamos, where the oleanders grow in the gravelly river bed. Plane trees and willows nurmur in the sea breeze; only thou, $\mathrm{O}$ ancient River, only thou art ever young, and dost flow on through the plain with inexhaustible flood.

"The first time I passed the ford the waters were disturbed, and I heard the rattle of the pebbles carried on by the stream while the clouds rested sadly on Mount Ida, and their undulating masses floated down into the valleys. Calm and clear didst thou return to thy bed, but to-day the sound rises again. For the last time I have forded thy flowery and perfumed stream, leaving my horse to find his way by instinct, stepping safely on the grassy bank.

"I have seen other and greater rivers, swifter streams. I have gazed on the broad S. Lawrence, where the eye cannot reach the further shore, but thy crystal flood, thy windings move me more strongly than all, and $\mathrm{i}$ yield to thy charm. I know no river more full of poetic memories, for thou hast seen the first rise of our civilisation, and from that time hast ever flowed swiftly, laying bare the roots of the plane trees, blending thy waters with the bitter juice of the oleanders, reflecting the silver leaves of the willows, and hast ever murmured thy song among shining stones of mica schist or the pink-tinted limestone pebbles. Thou hast wandered restlessly through the plain extending the land, while the blades of grass bent down in thy course, and generations of men have vanished like the leaves which thou bearest to the sea." 


\section{CHAPTER IV}

THE RUINS OF GORTYNA

I.

ORTYNA was a Greek city upon which the Romans built T another city. Both have disappeared; olives have grown above the ruins, fields stretch out between the fragments, and the bases of the grand walls of baths and basilicas, now levelled to the ground, form the boundary of little farms. I knew the name of Gortyna, for the walls of one room of the Accademia dei Lincei are adorned with a copy of the famous laws of this city, and as soon as I arrived I wanted to see the greatest inscription in the world. I was accompanied by Dr. Pernier and by the celebrated guide, Manoli Iliaki, who helped Professor Halbherr to find the inscription. Only one stone of this was known; it had been built into the mill house, and was removed to the Louvre by the Abbé Thénon, of the French School at Athens. When Professor Halbherr began the search at Hagii Deka, as the modern village near Gortyna is called, it occurred to Manoli to draw off the water from the mill, of which he is part proprietor, and after a search along the bed of the stream he saw the circular wall upon which the famous inscription is carved I (Fig. 42).

The surroundings among which this page of ancient legislation lies deserted, the sounding waters of the river Lethœus, the rushes which grow at the base of the inscription-all form so

I Professors Halbherr and Fabricius studied it in $188+$ and Professor Comparetti illustrated it in "Le Leggi di Gortina," Monumenti .fntichi, R. Accad. dei Lincei, 1903, vol. iii. 
poetic a landscape, that I cannot refrain from giving here the notes which I made on the spot.

$$
\text { "May 1-June, } 1906 .
$$

"On the right, near the theatre, are the ruins of a large Byzantine church dedicated to S. Titus; in front of this church are the remains of the ancient piazza, the agora of the Greeks, which has been excavated a short time since (Fig. +3). The

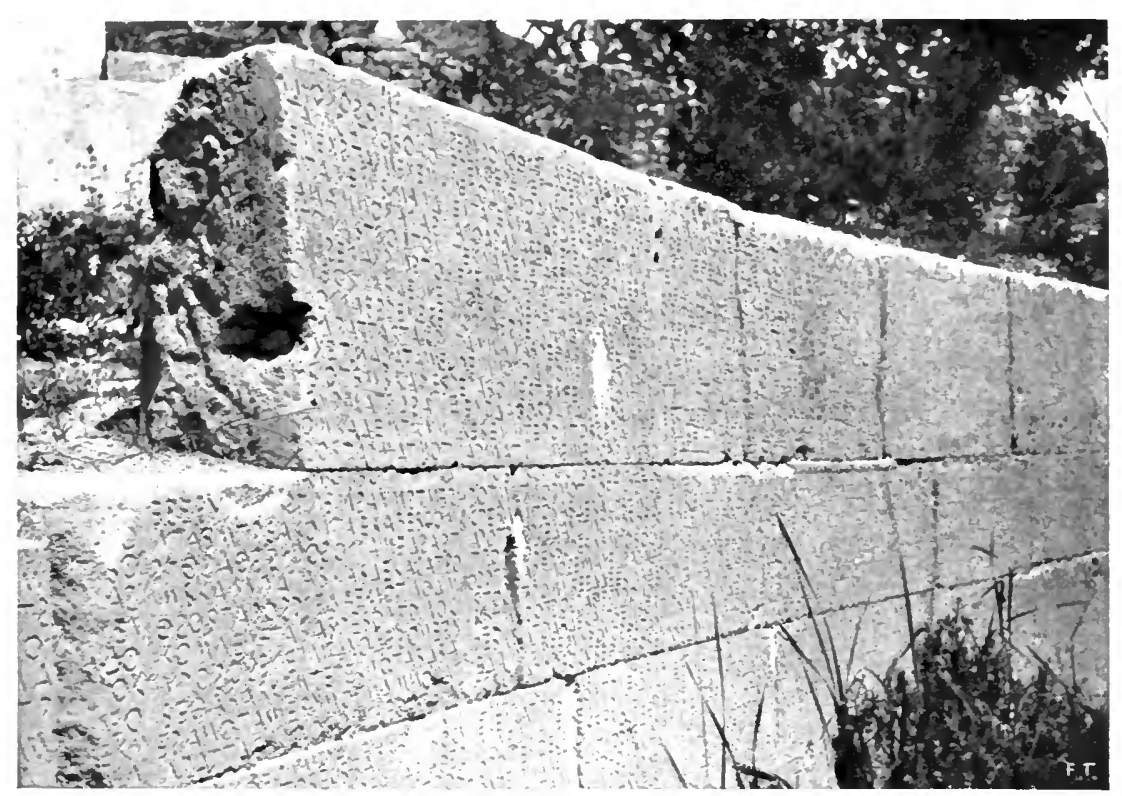

FIG. 42.-THE LAIIS OF GORTYNA.

branches of the century-old olive trees, with their gnarled trunks, bear a pale mantle of melancholy leaves. Behind the olives the dark, funereal green of the cypresses forms a strong contrast, and these slender trees rise up against the sky like minarets beside the cupolas of a mosque.

"To the right of the river Lethœus the remains of the Roman theatre, lying in the hollow of a little valley, show as a reddish patch among the golden heads of corn which rise from the orchestra. The breeze from the mountain ruffles the dense 
green foliage of the fig trees and diffuses the acrid smell of the juice like incense.

"This theatre did not suffice for the Romans, and they built another on the left bank of the torrent, using the material of the ancient Greek edifices. The blocks bearing the inscription were used for the Ambulacrum beneath the stepped seats of the theatre. Before moving them the Romans marked the blocks, so as to keep each in its proper position in order to preserve the inscription.

"I am writing these notes near the nill, sitting upon a column of grey granite which certainly came from Egypt. Further on there are other shining columns; the wild rose in full flower and some castor oil plants with their palmate leaves mark the concentric rows of seats.

"The old mill wheel makes a strange sound, sometimes like a burst of laughter: I think of the choruses, the Dionysiac songs which once awoke the echoes of the valley, and I imagine the splendour of the processions which passed into the cavea."

\section{II.}

I quote a fragment of the great inscription: I "The daughter heiress shall marry the eldest living brother of her father. If there are more heiresses and (more) brothers each shall marry the next in age, and if there be no brothers of the father but only sons of brothers, she shall marry the eldest (son of the eldest brother).

"And if the one who has the right to marry her be under age or she should be under age, the heiress shall have the house if there be one, and he who has the riglit to marry her shall have the half of all produce.

"And if there should be none having the right to marry her, as it is written, let her keep all her property and marry whom she will of her own tribe. But if none of the tribe will marry 


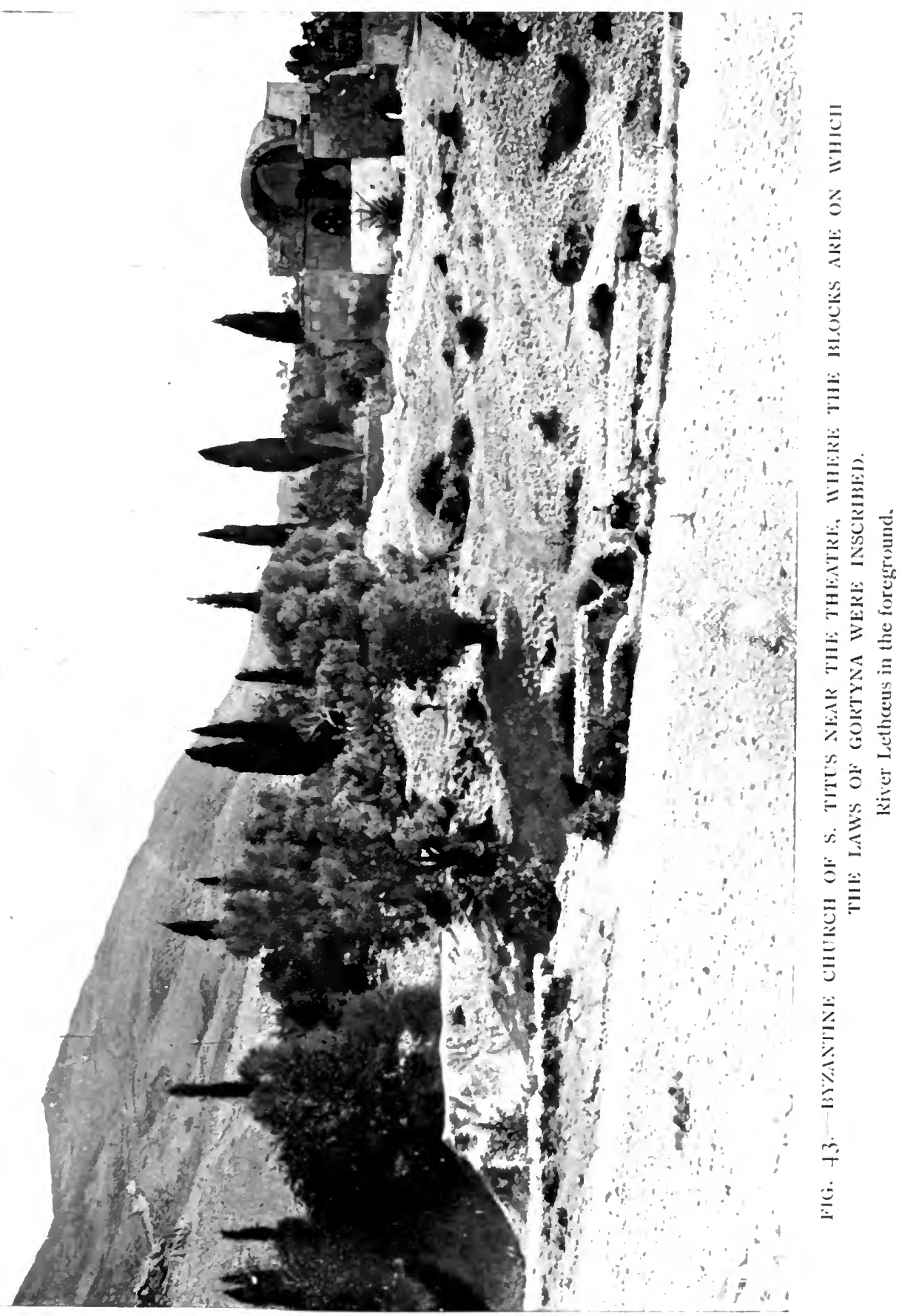



her, the relations of the heiress shall go among the tribe saying, 'Will no one marry her?' and if some one will marry her, let it be done within thirty days from when we have said (thus): if not let her marry whom she can."

This somewhat cruel law represents the primitive state of civilisation when families had drawn together and formed the town, but were not yet fused together.

The tribe or clan is unwilling to lose control of the land and binds the woman like a slave to the glebe. In the patriarchal family solidarity is a force which proceeds from instinct. Many centuries passed before this animal form of the clan came to an end and the common right of citizens suppressed the groups and brought about the independence of the individual. This brutal law written on the wall of a temple is the expression of a sentiment which still influences the mass of the peasants- the love of the land. The fear of seeing the holding diminished, the tradition that what the ancestor had accumulated must not be dissipated by the descendant, is the devil's own idea and is the torment of the rustic.

The opinion that hereditary diseases should be a reason against marriage between relatives is a recent one. Luther considered that consanguineous marriages should be forbidden, for if there were no religious obstacle a man would choose a wife without love from among his relatives in order to keep the family property intact.

At Athens many years later women still could not inherit with the men, and the husband had to possess the means of keeping his family. Here in Crete woman do inherit, but when the father is dead the daughter must sacrifice herself and marry a relative. In Rome only were the rights and independence of woman proclaimed unconditionally. The basis of the morality which to-day holds the nations of the world and the constitution of the family is the great progress which humanity has accomplished under the impulse of Latin jurisprudence. 
III.

Other inscriptions of the same kind have been destroyed and the stones used in building at various periods. Crete contains almost more archaic inscriptions than the whole of Greece. The temples were covered with inscriptions of codes and decreeslaws on certain points of public, sacred, or private rights which were promulgated by carving them upon these buildings. The most archaic texts are those on the walls of the Sanctuary of Apollo in the centre of Gortyna. They are written in the most primitive form known of the Greek alphabet.

We know no more ancient written laws in Mediterranean civilisation than these in Crete. Oral tradition ended when the duties and rights of man were inscribed on these stones. There was as yet no coined money; ${ }^{\text {I }}$ the lebes or caldron served as the standard of value, and with the lebes, the tripod on which it stood. When Achilles arranged the games for the funeral of Patroklos he offered " to the winner a great tripod for the fire." 2

The great inscription of Gortyna is of the sixth century в.с., the lesser inscriptions are of the seventh. In them the lebes and the tripod figure in definite numbers in the fines and indemnities. The last stage of the ancient system of purchase by barter still prevailed, and values were determined by means of certain animals, of which the numbers were recognised in business dealings. Coined money, which was invented later, was rapidly improved till it attained to the perfection of the Sicilian coinage, which has never been surpassed.

\section{IV.}

History says that Gortyna had a circumference of 50 stadia and it certainly gives the impression of having been a great city when we find the first columns half-way down the mountain, and the extensive prospect embraces the ruins of basilicas and baths in the midst of fields and olive plantations. There is an air of

x The first money was coined in Greece about 600 в.c.

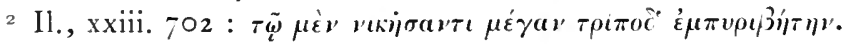


solitude and abandonment over all, for the difficulty of the road, which descends by almost inaccessible precipices, is a barrier to all but a few archaologists.

On a piece of ground near the basilica, commonly known by

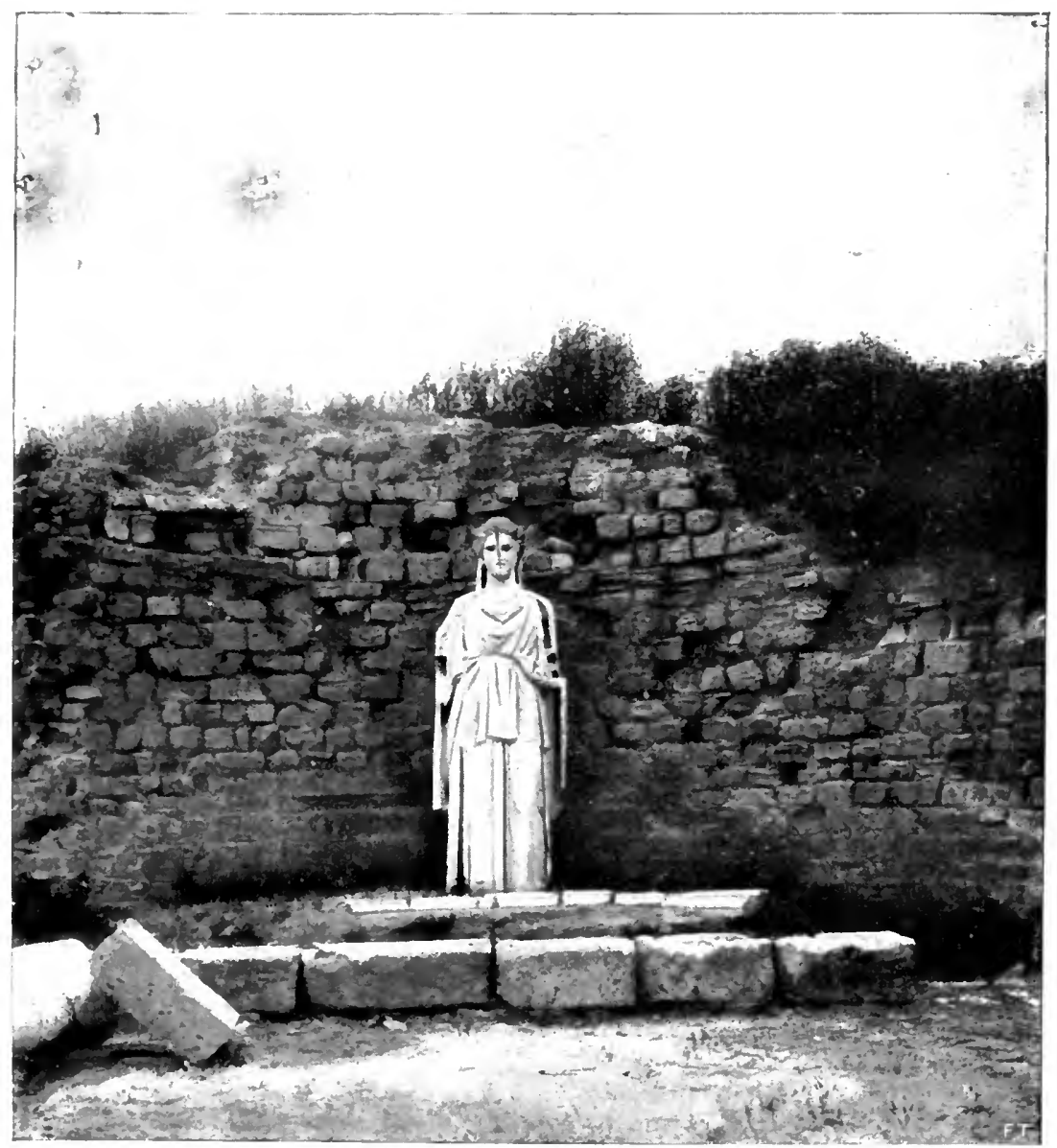

FIG. H.-APOLLO OF GORTYNA.

the name of pretorium, Professor Halbherr discovered the Temple of the Pythian Apollo I (see Frontispiece). A pestilence having

I Described by Professors Halbherr and Comparetti (Monumenti Antichi, R. Accad. dei Lincei, vol. i.). 
broken out in Beotia, the daughters of Orion, the celebrated giant, spoken of by Homer in the Odyssey, sent messengers to consult the oracle of Apollo Gortynio in this temple. In the apse is the statue of the god, which has been raised from the ground by the Italian Mission (Fig. 44). On the right the yellow marguerites form a golden aureole, while the ripe ears of corn are seen in the fields opposite. We know that the temple stood in the centre of the city, but now the cows are grazing among olives and cypresses which breathe the quiet poetry of the fields.

Apollo is the god who represents the new right of nations in contradistinction to the savage life of a primitive age. It was Apollo who led the Greeks to civilisation. The priests of Delphi were brought from Crete, and Homer's Hymn to Apollo may have been written for this temple. The old building has dis-appeared, and it was rebuilt and enlarged in Hellenistic and Roman times.

Beside the temple is a Heroon. The ancients did not allow tombs within the sacred enclosure, but there was certainly one very illustrious citizen for whom the city of Gortyna made an exception, and raised to his memory this tomb near the entrance to the temple. Now his very name is lost and his bones are scattered. Four steps of Pentelic marble lead to the uncovered tomb, within which the poppies have spread a purple pall.

\section{V.}

At the time of the Roman dominion Greek artists used to keep statues without heads ready in their shops so as to facilitate the trade in monuments. They had emperors wearing the cuirass, consuls in the toga, philosophers, orators, and poets with the teca and roll of writing at the foot. They were quite finished except the head, and that was done as soon as the order was given. The four statues of Fig. 45, photographed under the direction of Professor Halbherr, were made in this fashion. An author, two consuls and an emperor have lost their heads by the strange irony of fate and have again become anonymous as in their early days 


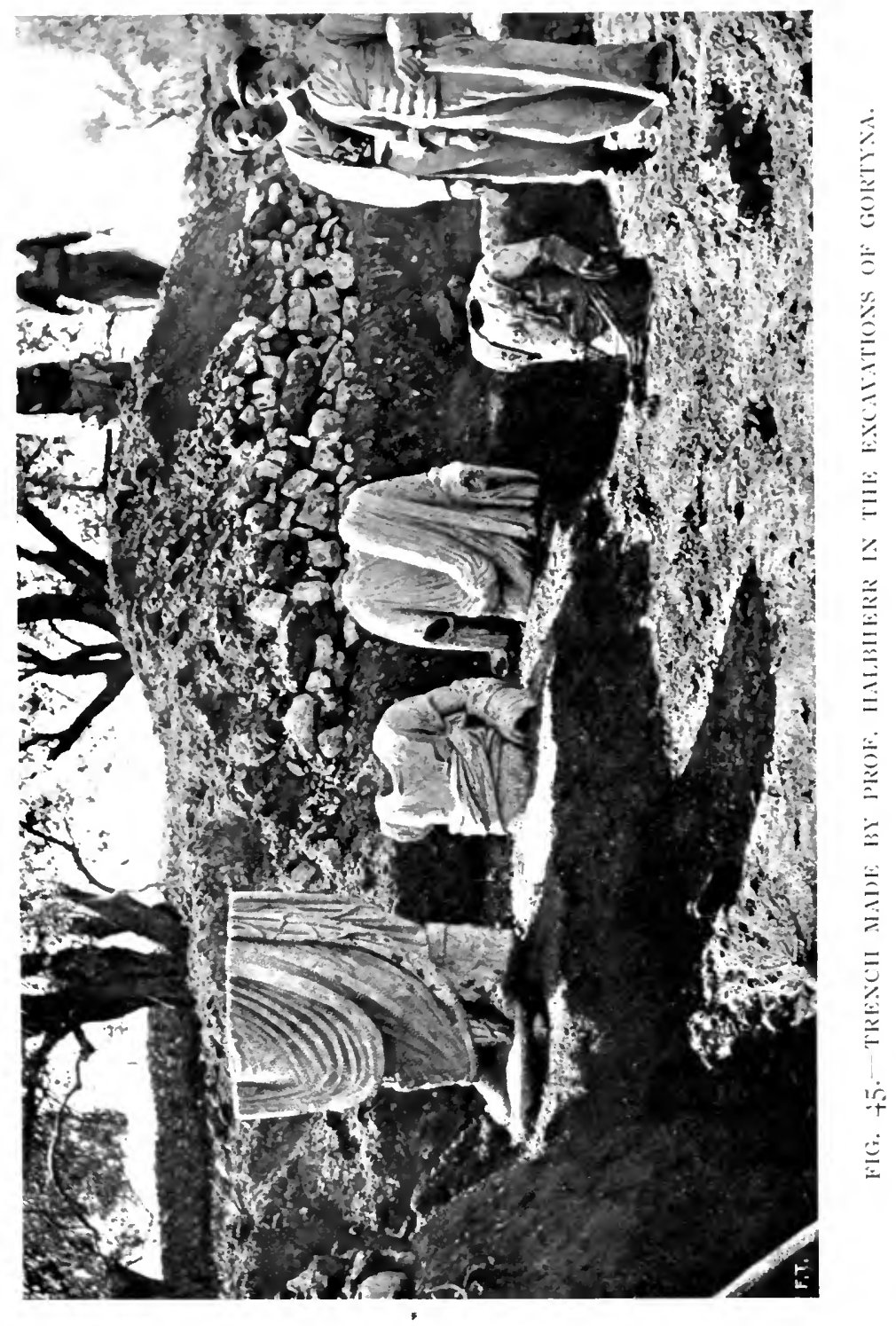



in the warehouse. It seems like the destruction of marbles when the Roman Senate ordered the damnatio memoric in the time of Nero and Domitian, when the statues of the emperors and their officials were overturned and decapitated.

"Gortysa, Fune 1, 1906.

"To-day I have seen a sad picture of human inconstancy in a field far from the road and at such a distance that I had to go on horseback to the spot. But it was a record of my favourite author, Marcus Aurelius, and nothing would have kept me from rendering homage to his memory.

"At the end of a block of masonry the tablet to Marcus Aurelius and Lucius Verus I appeared like a white patch in a field of deep, almost blue green tobacco. Taking off my hat, I approached and read the inscription. After the Medes and Parthians had been overcome by Marcus Aurelius a monument was erected at Gortyna to this celebrated writer and philosopher and to other emperors, but the monument having been destroyed another was set up in its place.

"We know that Marcus Aurelius had been in Egypt and he probably stopped in Crete. During this voyage died the famous Empress Faustina, who followed her husband in all his wars and called herself the mother of the soldiers. I thought of the festival with which the stone was inaugurated and of its present abandonment. Even then the little temple which contained the statues of the emperors had fallen into ruin and ought to have been rebuilt; near the stone were two great heaps of bricks and tiles, covered with ivy, and in the distance stretched the plain. The yellow ears of corn bowed beneath the wind, and rustled faintly as when a hand passes over a silk garment. The words of Marcus Aurelius came to my mind:

" "That which is dead falls not out of the world, for all things remain there and are transformed and dissolved into new elements of their own, which are those of the world and of which thou art formed. Without murmuring all things are transformed."

I For the photograph of this tablet I have to thank Dr. Pernier, who kindly helped me to prepare the illustrations for this book. 
VI.

The roads through the fields are as broad as in the Roman Campagna, and along the ditches the wild flowers display all the beauty of varied colour; yellow marguerites grow to the height of a man and seem to want to hide from the traveller the vulgar growth of lupins and peas. The great umbelliferæ offer the white and pink-tinted cups of their honey laden flowers to the bees, while the mallows spread a purple carpet upon the dust. In the midst of an orchard a great Ionic capital with its volutes and acanthus leaves serves as a table beneath a pomegranate tree. The blossoms hang like festoons of roses and the crimson flowers shine through the leaves. The olives, too, with their centuryold trunks, are like the ruins. The old trunk is dead, and seems like a heap of ruins where new generations which have shot forth near the base of brown wood form a group of new trees.

Upon a shining granite column I read the name of Septimus Severus; this is a mark of homage often paid to one of the emperors. The vivid red colouring still shines from within the lettering. Fragments of precious Cipollino marble, with beautiful veinings, lie in a ditch among rushes and water lilies.

\section{VII.}

I could often have imagined myself in the Roman Campagna. The flocks of crows with their notched wings, cawing as they flew round the ruins of the prætorium, reminded me of the baths of Caracalla, but in this Cretan landscape there is more poetic feeling; the columns and the ancient capitals have been left in place to support the trellised vines, while here and there a great capital of Pentelic marble, with acanthus leaves carved in marvellous relief, is built into a boundary wall among the loose stones. Another similar capital was standing in the village street; it had been hollowed out like a cistern, and served as a drinkingtrough for the cattle. 


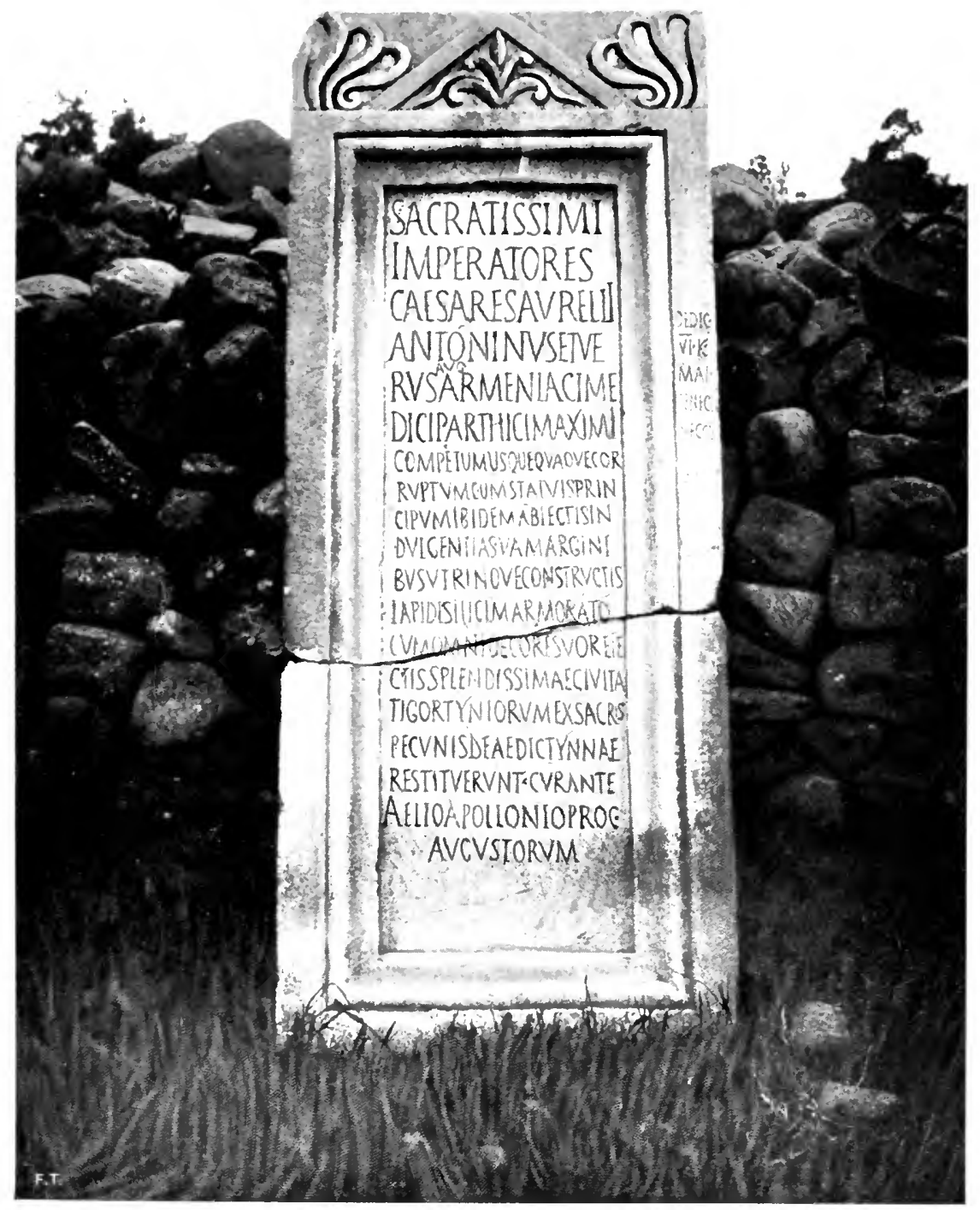

FIG. 6 - TABLET IN HONOLR OF MARCES ALRELILS AXI IUCIES VERLS. 

Bases of pillars, triglyphs, and metopes had been pushed aside to the edge of the road to clear the field for the plough. Whereever an entrance is opened into field or vineyard some pediment or sculptured fragment is always found. A stone, with archaic inscription, which had been cast into the foundations of the basilica, saw the light again when the walls were overthrown by

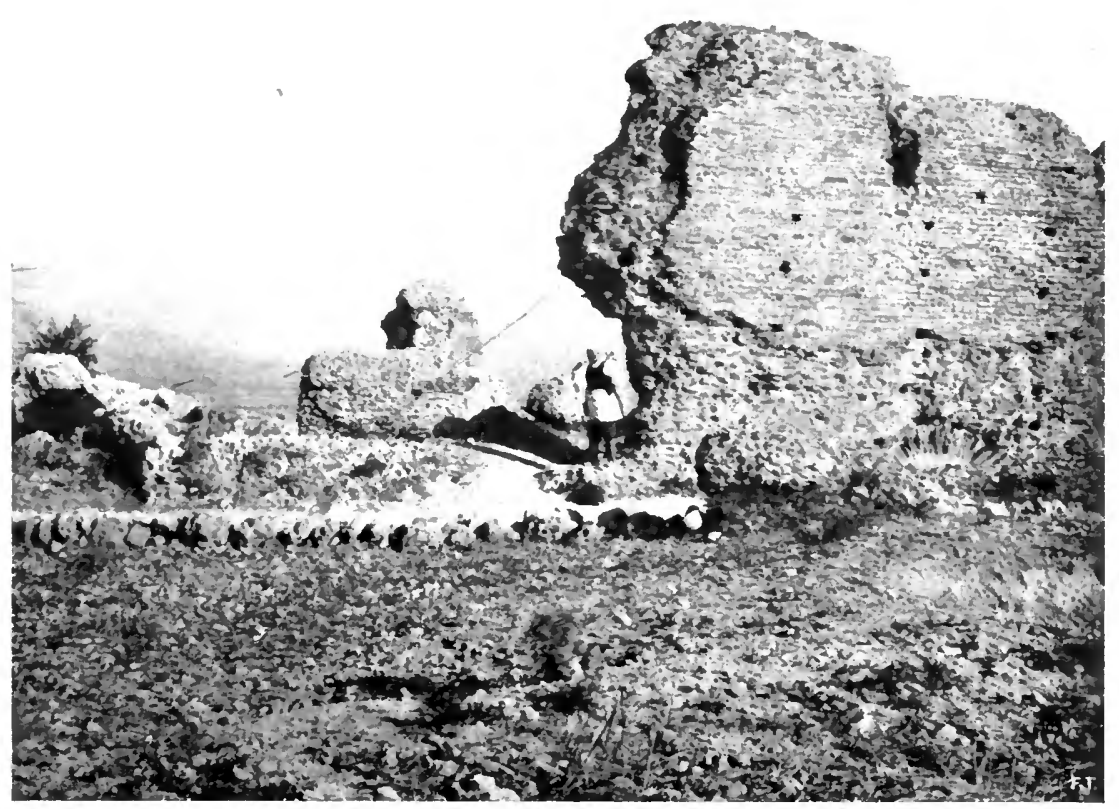

FIG. 47--ROMAN BATHS AT GORTYNA.

the convulsions of an earthquake, or through the shock of the falling roof.

The oleanders growing beside a little brook, the plane trees with their deep-cut leaves and bunches of woolly balls, the tamarisks and the wild almonds form a pastoral picture which recalls the idylls of Theocritus. 


\section{VIII.}

The Greeks are hospitable and their houses are clean, and I found in Crete a profusion of linen unknown in Italy. At a distance from the towns the traveller must ask the peasants for a lodging, and they always give it for the love of strangers. This hospitality is called philoxenia.

Among the pleasantest recollections of this friendly hospitality is the house of Manoli Iliaki, at Hagii Deka. I spoke of him at the beginning of this chapter, and now give his portrait (Fig. 48). On first entering the farmhouse one would fancy oneself in a museum were it not for the manure heap in one corner, and beside it the torso of an athlete, with a cock perched on the top, crowing in the midst of the hens which were scratching about. When I saw the athlete I at once thought of Satornilo of Gortyna, who was twice champion of the Hellenic world at the Olympian games. Sadly and reverently I looked at him. I had just come from the Olympian games at Athens, and I shuddered to think that the image of Satornilo, who had made the hearts of Greece beat high, should end beside a dunghill. On the opposite side, near the door, the courtyard is truly worthy of admiration. Purply blue campanulas grew up along the curves of a fluted column, and leaning against the wall was the torso of a Roman emperor wearing a cuirass with the head of Medusa in the centre. From the exquisite skill with which the Nike was carved on the metal covering the leather on the shoulders, the statue was evidently the work of a clever artist; the other mutilated statues, too, are of value, but I will not stop to describe them. The staircase in the corner to the right is made of the bases of columns reversed and set one above another to form the steps. As I went up to my room I wondered that architects do not more often make use of so simple and symmetrical a form of staircase.

On the terrace above I admired a Herm, which served as a pilaster, and some inscriptions which Manoli prides himself on having collected entirely in his own domain. These are mostly archaic boustrophedon inscriptions, and I could not even read 


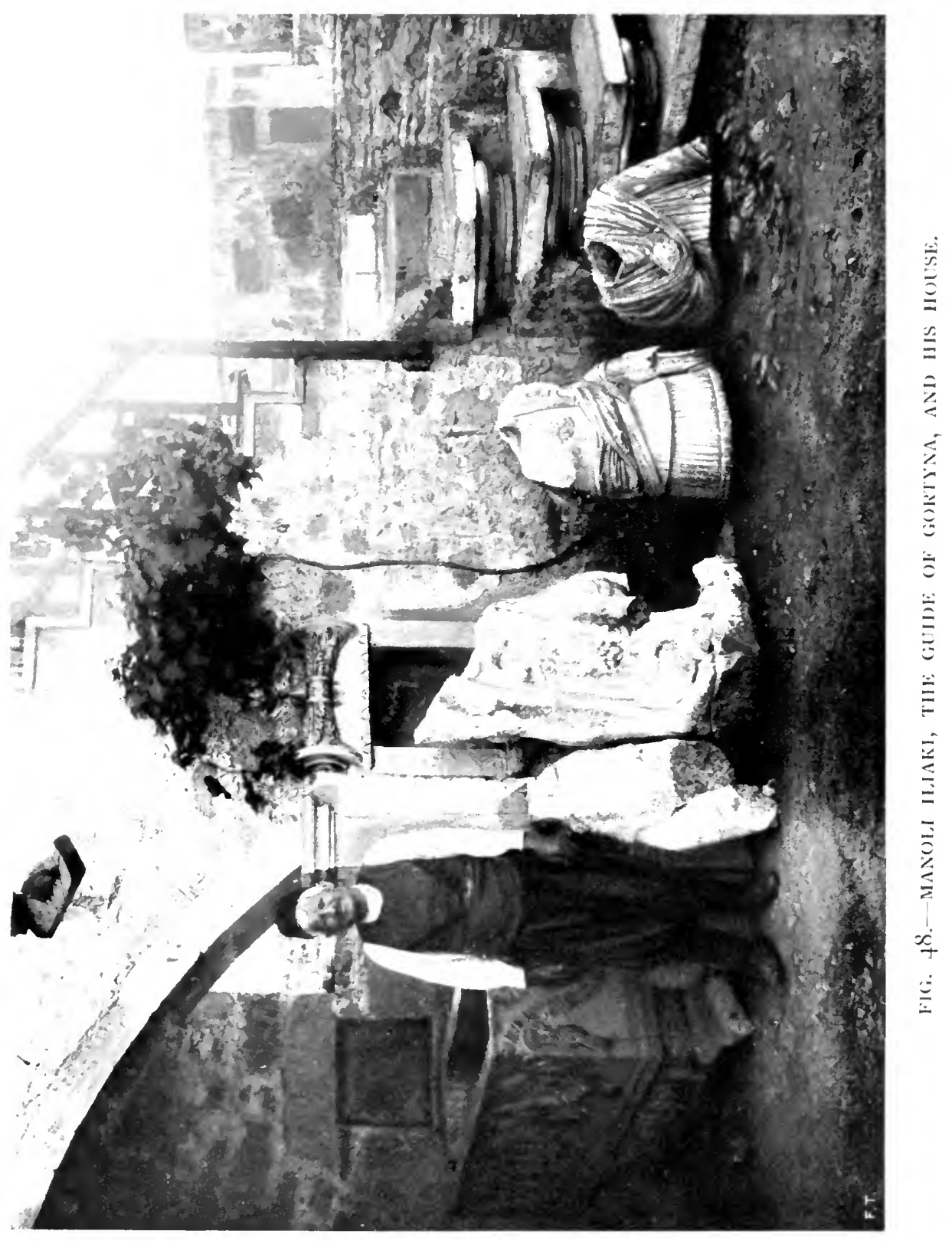



them, as the characters are different from the Greek letters which I learnt at school. In the room where I slept there was a bust of Esculapius in a niche, and the lamplight showed up the majestic beard. The same light which shone upon the face of my master fell also upon the cella of an ancient temple, and I fell asleep looking at it. In the morning I was awakened by two swallows fying about the room. I opened the window and saw that they had built their nest upon a beam of the ceiling. They went in and out, hovered in the air, or perched twittering on the iron bars.

In the peace of this distant corner of the island I thought of Homer, who speaks of strong Gortyna. Without blazed the classic sun of Greece, the sky so blue and bright that nothing could equal it. The doves cooed in their guttural voices that sounded almost like a lament, following one another, stopping for long kisses on the edges of the roof, and flapping their wings with happiness.

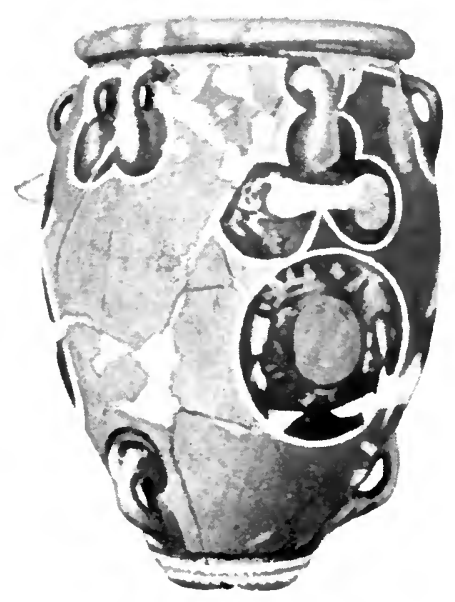

FIG. 49.-KAMARES VASE FOCND IN THE MOST ANCIENT PALACE OF PHASTOS. 


\section{CHAPTER V}

THE PALACE OF KNOSSOS

I.

A hour's ride from Candia brings one to an enclosed Mussul-1 man monastery. Behind the wall which surrounds it stands a few cypresses and a graceful palm tree which bends forward as if to offer its dates. Above the fountain where horse and traveller stop to drink is a tablet which inform us that here rises a spring dear to believers in the Koran. The inhabitants are Bechtascide dervishes - that is, members of a brotherhood who marry and cultivate the fields. Outside the enclosure a windmill with triangular sails stretched between the spokes of the great wheel pumps the water which irrigates the cornfields. In the next field a descendant of Mahomet is sowing peas ; he has made a pilgrimage to Mecca, as his green turban shows. A boy with a sack slung round his neck hands him the seed, while another goes in front driving the plough - the old wooden ploughshare described by Hesiod in "Works and Days." A little further on the ruins of a Roman basilica form a series of equidistant red patches in the midst of a field where the remains of broken arches still stand. The warm spring wind was swaying the barley blades, and the reflections of the sunlight looked like little white flowers among the young plants. Upon the hill within this shining green frame are the ruins of Knossos (Plates I. and II.). ${ }^{1}$

The present road to the palace leaves the cart road at the point I Dr. Evans's plan, drawn by Theodore Fife, is shown in two parts. 

PLATH

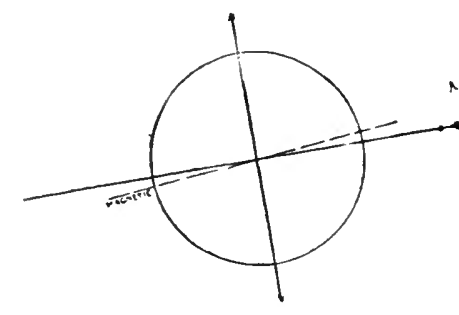

MEASURED AND SFAWN BY THEODORE FYFE
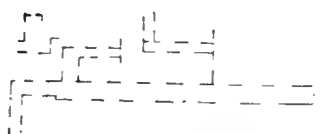

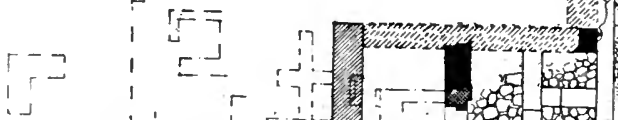
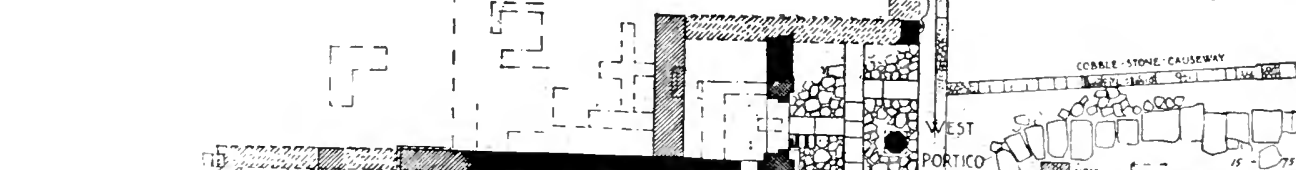
U
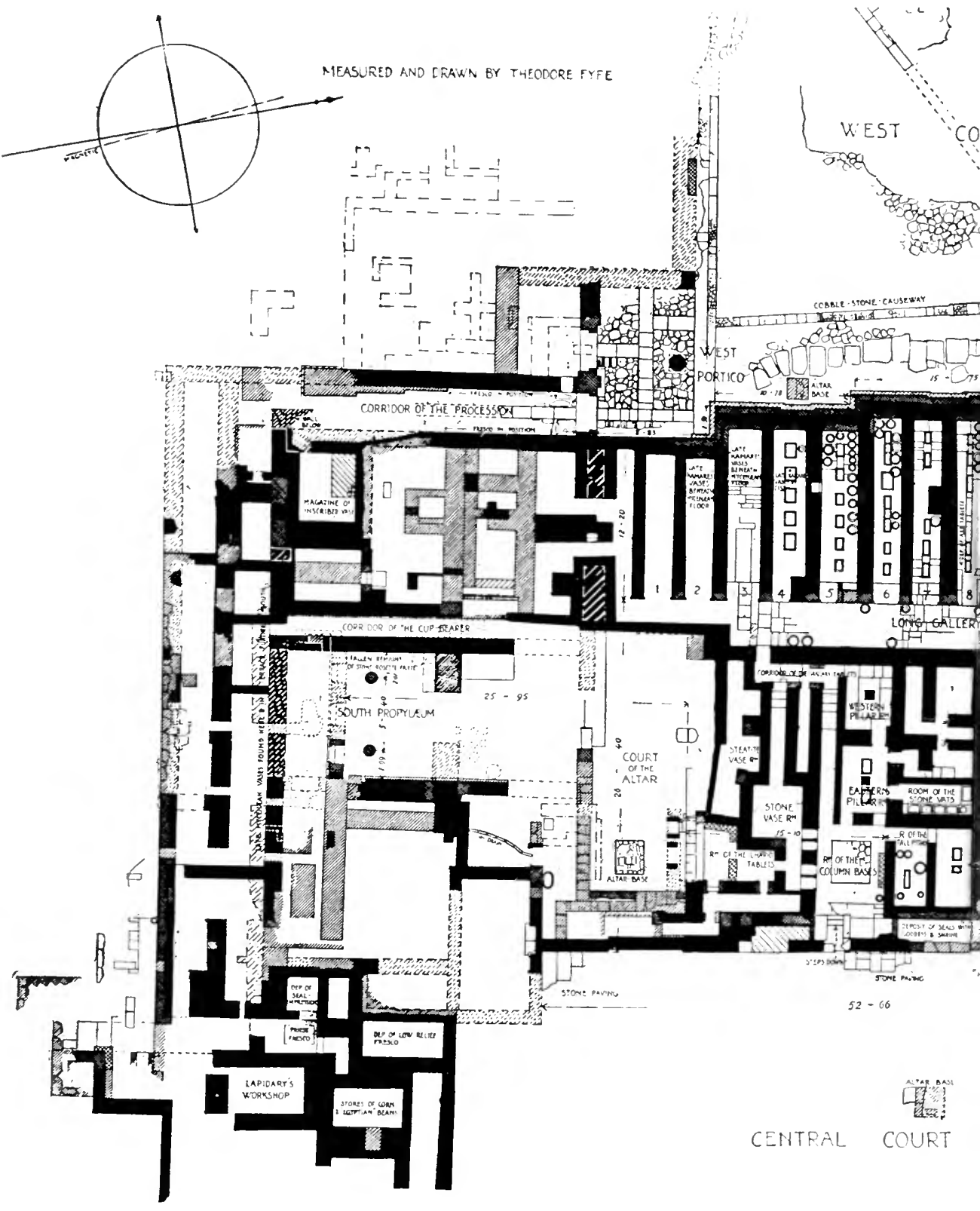


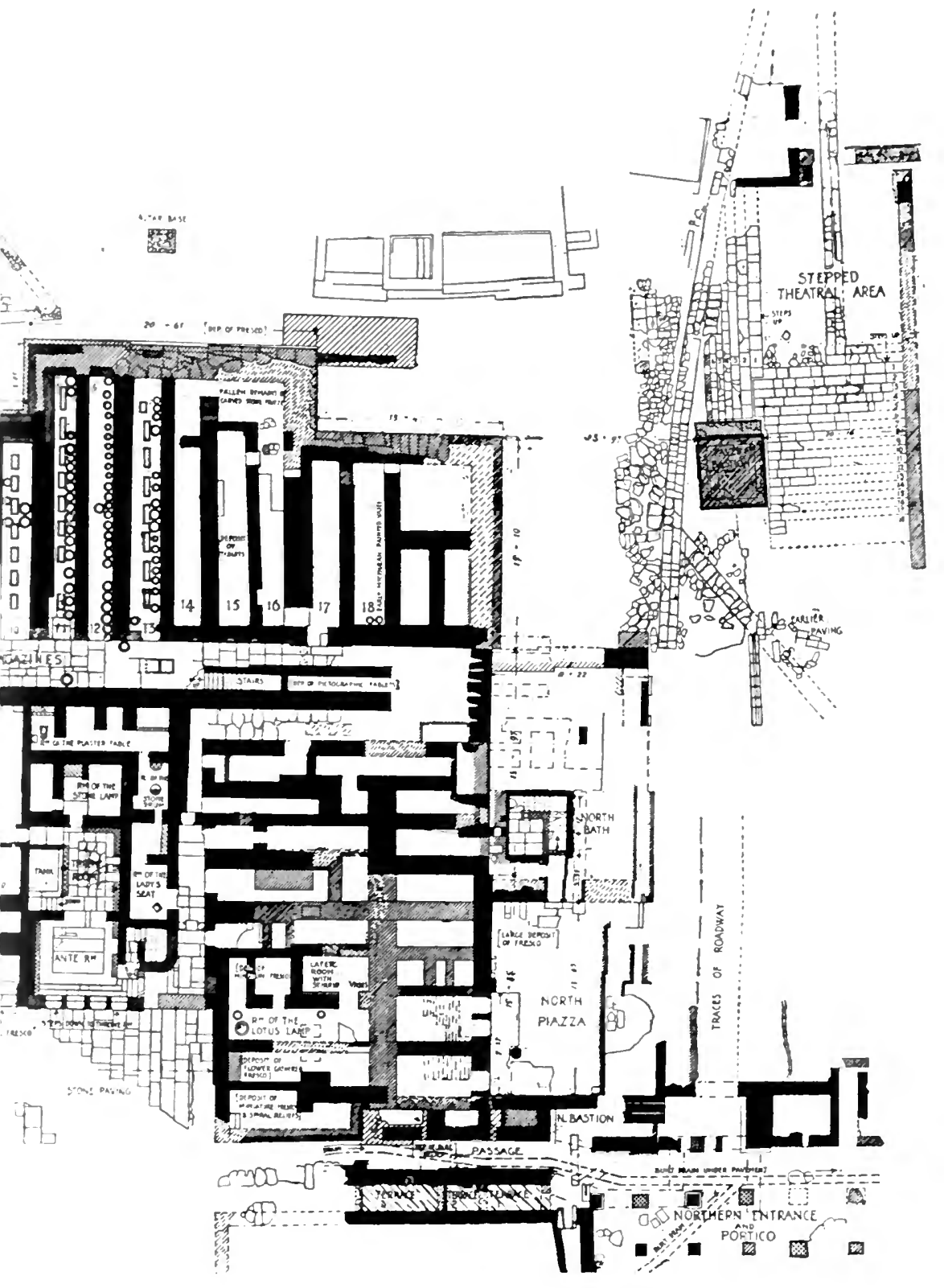



shown in the right-hand cormer of Plate I. It branches off into two footpaths, of which one leads to the theatre, the other to the palace. In I $90+$ Dr. Evans opened a deep cutting along this path. Here are 300 metres of prehistoric road formed of great slabs placed in a double row side by side; some of these stones measure as much as $2 \frac{1}{2}$ metres in length by 60 centimetres in width.

The journey of Theseus to Knossos was one of the subjects dearest to the Greek poets, and I hoped that I was walking on the road to the palace of Minos over which Theseus and Ariadne had passed after the killing of the Minotaur.

IJ.

Nothing could be more instructive than this walk along the cutting which leads to the palace of Knossos. The long, wellpreserved footpath descends for above 100 metres and then rises again, following the curve of the original valley. But during the centuries that have passed this has been filled up with earth and detritus to a depth of 6 or 7 metres above the ancient road, and the plain now covered with cornfields was formed. Dr. Evans discovered here the pavement of a Roman road, and beneath this at a depth of 2 metres is the footpath of the Minoan age.

There is a constant levelling process going on, the effect of the storms and rain which bring down the earth at regular intervals. From the Mycenæan to the Roman age about the same period of time has elapsed as that which divides us from the Roman Empire, and the depths of the deposits of soil correspond to the chronological periods of history. In the sides of the cutting, besides potsherds, tiles, and unbroken bricks, we saw the terracotta pipes in which the supply of drinking-water was brought during the Roman dominion.

In this small space valuable materials for the study of hygiene may be collected. Here we have the conduits of the Mycenæan age, and can compare the pipes of four successive civilisations. 
After the Roman times the spring which now supplies water to Candia was conveyed in another system of pipes by the Venetians, and later on the Turks, too, made a fresh system for the supply of water. The Mycenæan pipes found beneath the pavement of the room of the olive press are shown in Fig. 50. The sections are well jointed, and have a raised collar which enables the cement to hold the pipes well together. (The measurements are indicated in centimetres.) The pipes are made of fine, well-baked clay, and cemented with such good lime that several pieces were broken at the joints without separating the cement from the pipe.

At the time of Homer water was already conveyed in pipes from one place to another. Near the house of Odysseus in Ithaca "appeared the fair fountain, made by art, which brought

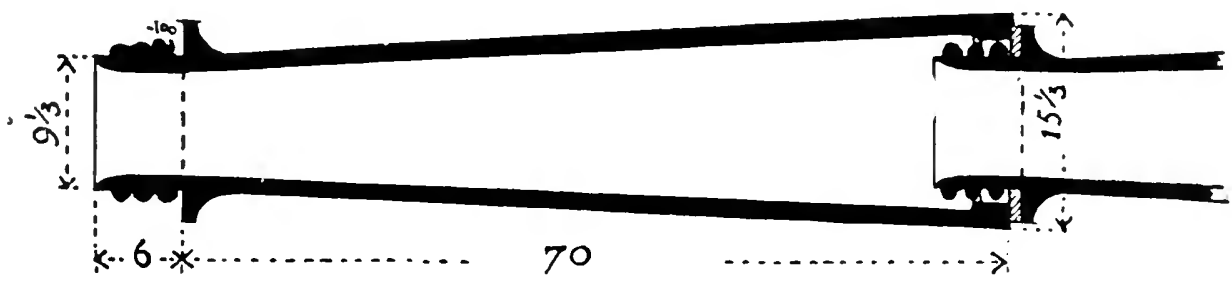

FIG. 50.-MYCENAAN PIPE OF TERRACOTTA FOR THE DRINKING WATER SUPPLY.

a pure stream of water through the grass-three Kings had made it."

Professor Dörpfeld, director of the Archæological Institute in Athens, showed me the pipes which he had brought from Ithaca. I The pipes successively made by the Romans, Venetians, Turks, and the present municipality of Candia, were continually made of greater size, as a more numerous population required a larger supply of water; but the fineness of the clay, the quality of the cement, and the exactness of the shape gradually deteriorated.

These facts may cause some doubts to arise in the minds of those who have hitherto believed that progress in all things is constant.

I They are of yellowish clay, well baked. Length, 3 I centimetres; inside diameter, $92 \mathrm{~mm}$. in one direction, and 60 in the other. 



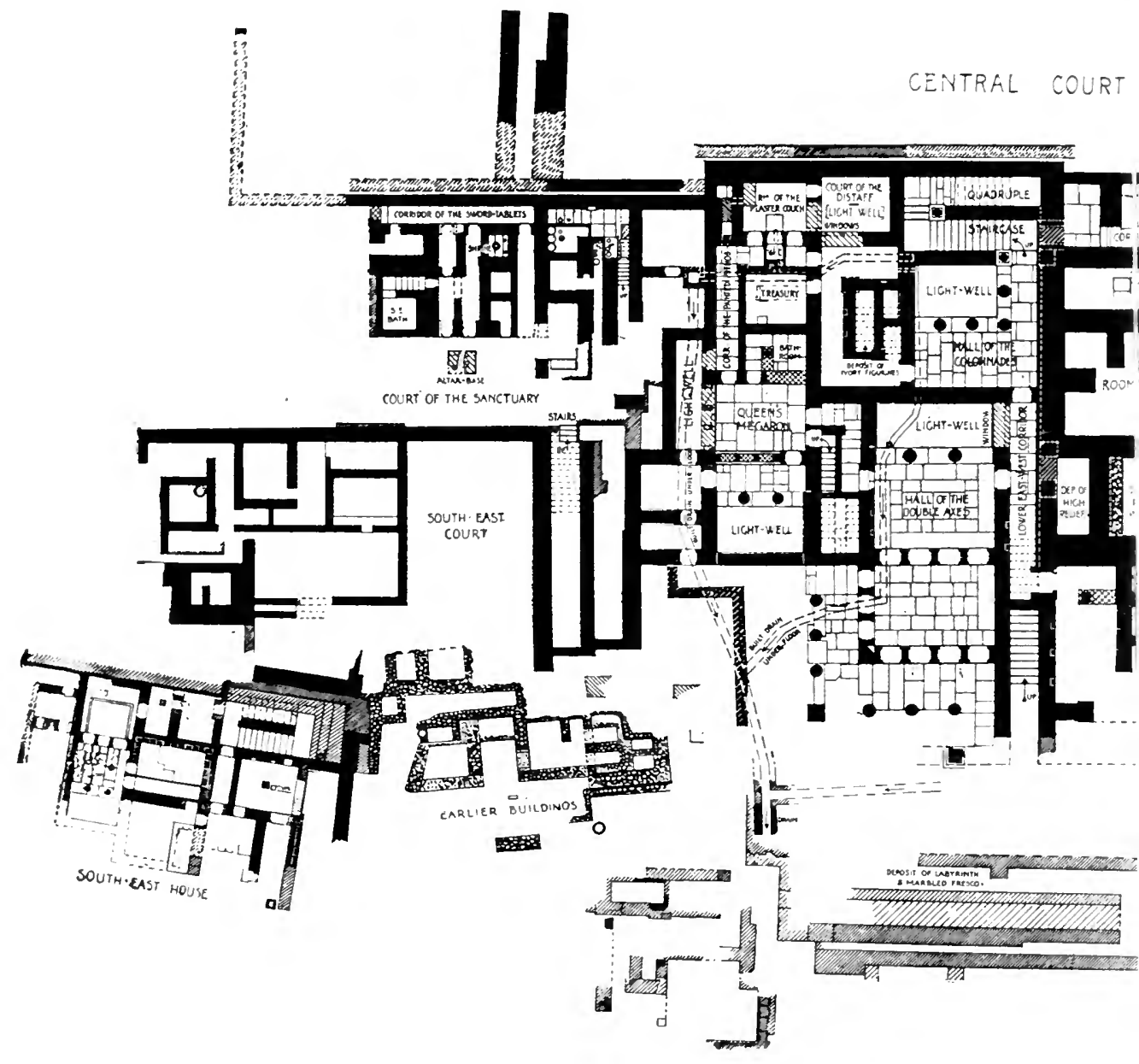




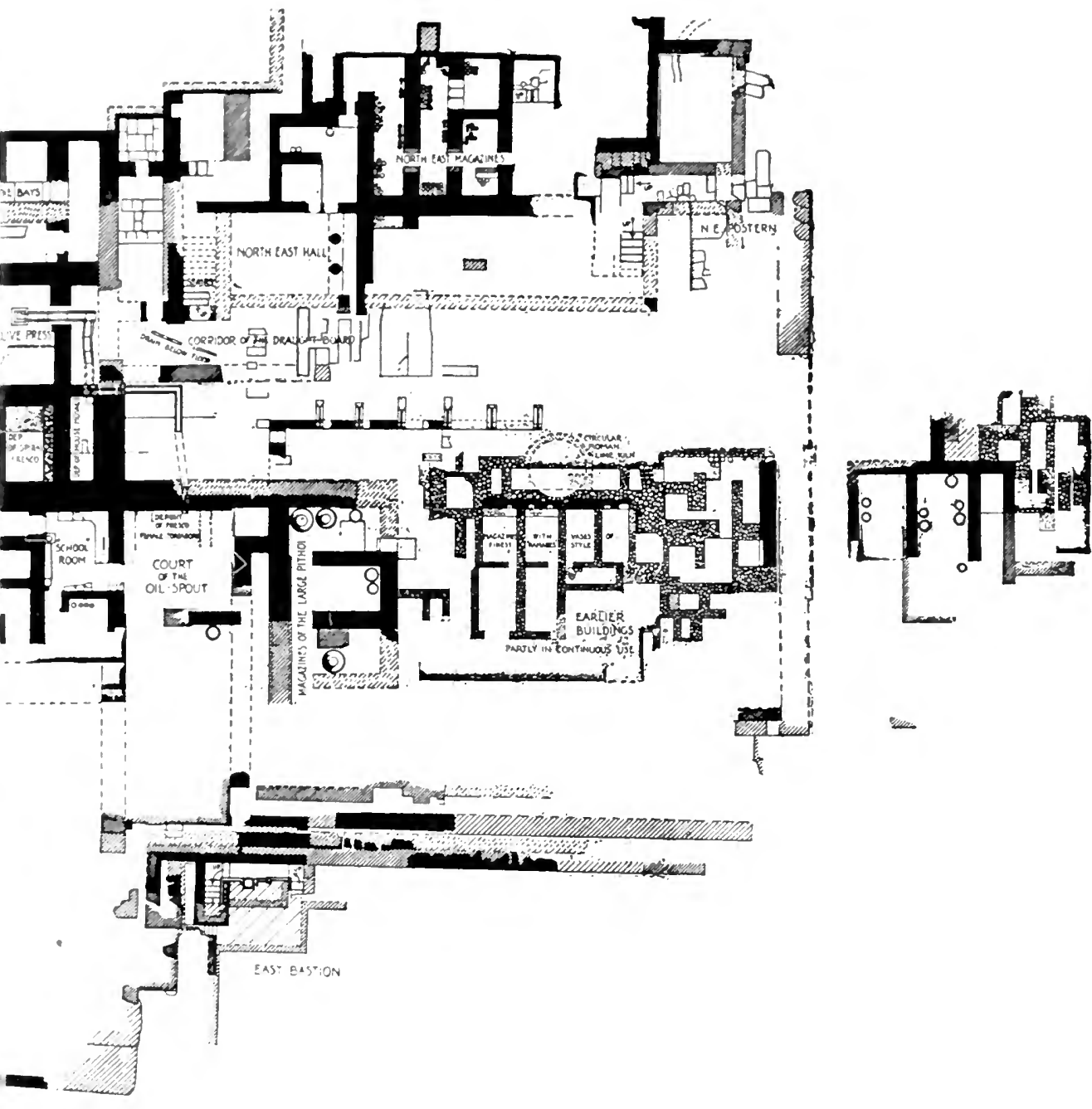

[To jace tase II4. 



\section{III.}

Beyond the theatre there are traces of a road leading to the northern entrance of the palace. Here is a portico with a double row of columns, six on each side, $2 \frac{1}{2}$ metres apart. This was probably the chief entrance to the palace, for it faced the port. The base of the columns is made of blocks of gypsum more than a metre high and 80 centimetres in breadth. Fig. 5 I shows some fragments of these columns; beside them are two great

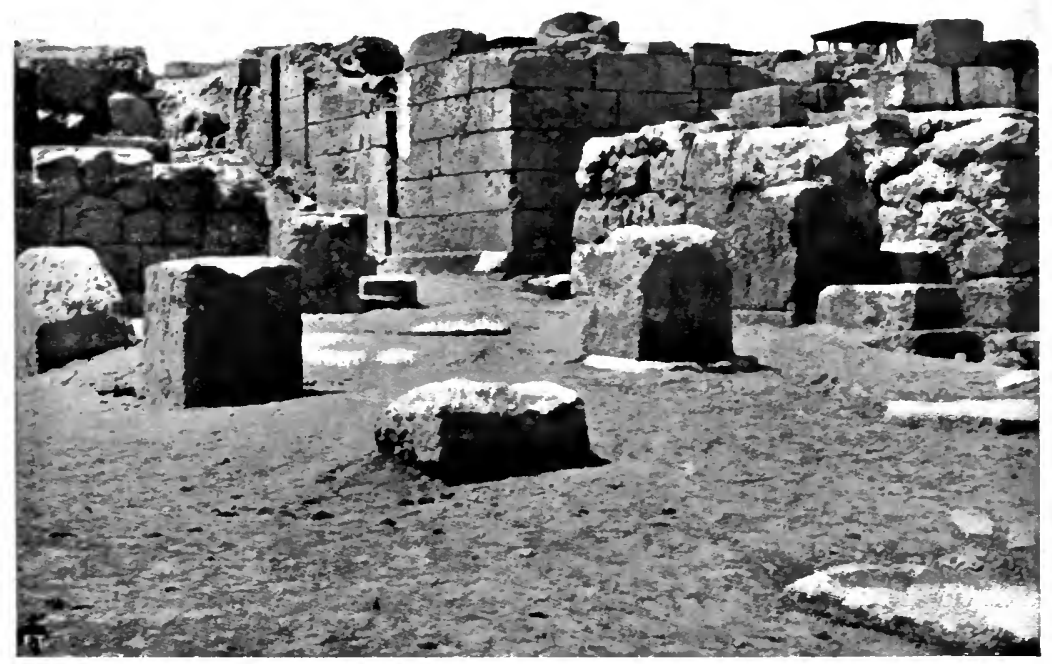

FIG. 5I.-NORTHERN ENTRANCE OF THE PALACE OF KNOSSOS.

bastions which hold up the earth, and between them the flight of steps leading to the central court.

On the steps of the theatre I was struck by a channel against the side walls to allow the water from the slightly inclined steps to run off on either side-a small detail which shows how far advanced was architecture in the Bronze Age. Fig. 52 shows the runnel which carried off the water from the central court. I

I The photo was taken from the north side of the court, facing the palace entrance; the runnel passes along the wall to the left. 
I have already said that the palace had a system of pipes for the supply of drinking water, and this explains why this rain-water was allowed to be wasted instead of being collected in a cistern as at Phæstos.

There is on the western side another court surrounded by a stone bench which forms a base or plinth to the walls of the palace. This court was probably the piazza with the entrance used for solemn receptions, and here a great painted bull was found ; one corridor contained another large fresco, representing a procession; men carrying vases form a grand cortège in which the figures are painted life-size; the border of their long garments is magnificently embroidered.

IV.

For the better comprehension of the historical importance of the planimetry of this palace I must refer to the most ancient dwellings in Italy and in Europe. In I 853 there was a great drought, and the unusual deficiency of water caused the bed of many of the Swiss lakes to be dried up and the earliest lake dwellings were made visible. It was seen that man in self-defence had built houses upon beams and piles driven into the bottom of the lake. In I 86 I Gastaldi, and immediately after him Pigorini, began the studies which ultimately proved that the whole subAlpine region, from Piedmont to the Euganean Hills, was from the Stone Age to the beginning of the Iron Age inhabited by a people who lived in pile dwellings.

The terramare, which appear like little mounds in the waters of Upper Italy, are all alike ; and in some are found three or four rows of pile dwellings constructed upon thousands of staves and piles. It was at first believed that the people of the pile dwellings came from the north, and after crossing the Alps had planted themselves on the lakes and in North Italy, but now it is admitted that the movement was from the south towards the north. 


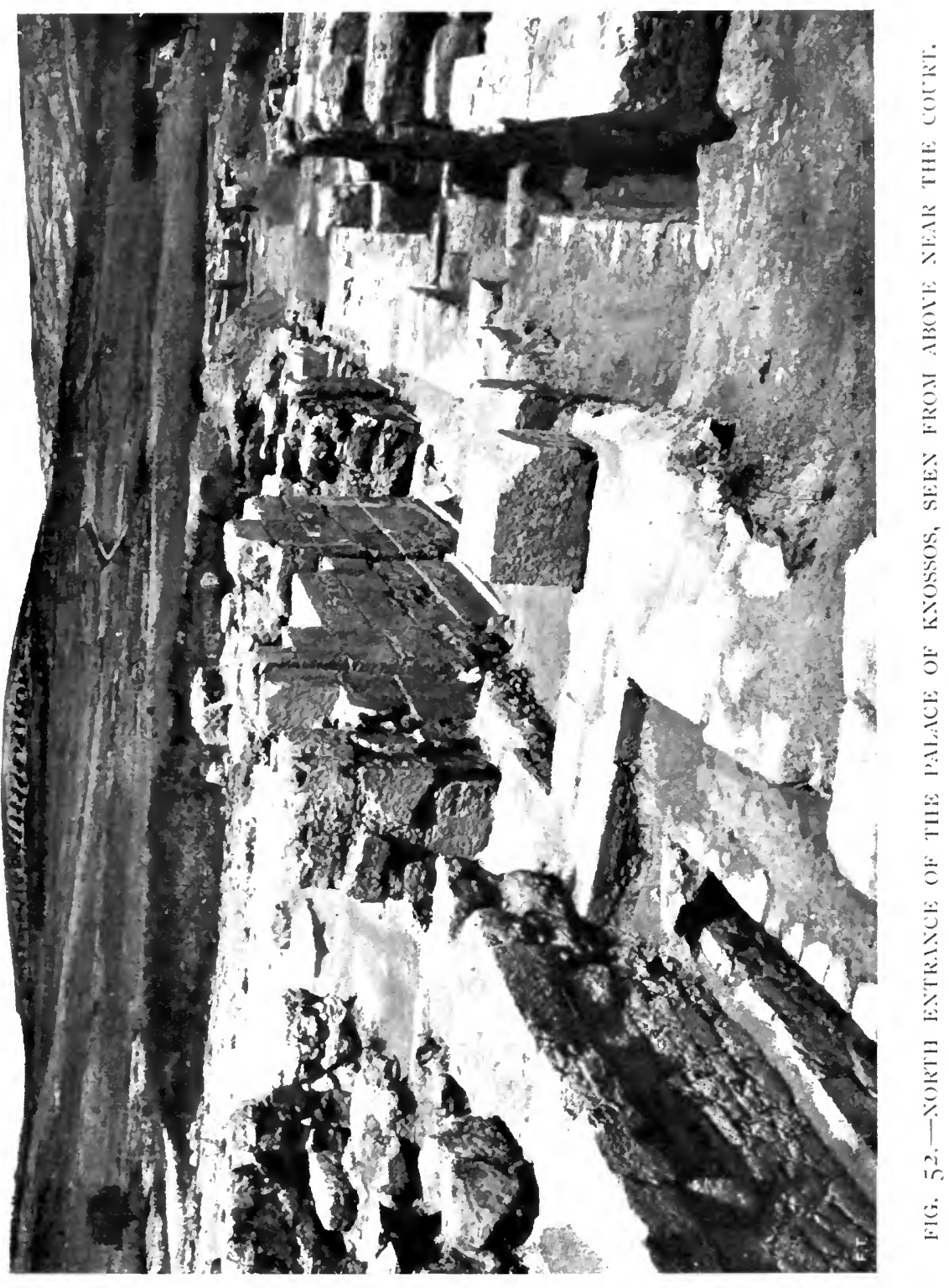



The Etruscan city found at Marzabotto, near Bologna, and described by Brizio, I so closely resembles the palace of Knossos, that their common origin must be recognised. Like the palace of Knossos, it was traversed by two great roads: one the via decumana, from east to west; the other, the via Cardinale from south to north; there are other lesser cardinal ways which intersect the decumana at right angles.

But before the discovery of this Etruscan city, Chierici and Pigorini recognised in the quadrilateral form and the orientation of the terramare the primitive form of the Italic city. ${ }^{2}$ And it must be admitted that the pile dwellings are less ancient than the primitive palaces of Crete, for the bronze fibulæ which are found in the pile dwellings are not found in the Minoan and Mycenæan periods in Crete.

In the central court of Knossos Dr. Evans found objects from Egypt of the time of the XIIIth Dynasty-about 2100 B.C. Other Egyptian finds are of an earlier date, about 2800 B.c. But the buildings are older, and Dr. Evans dates the first palace of Knossos as far back as four thousand years before Christ.

The most ancient lake dwellings belong to the Stone Age; that decides nothing, as the slow spread of civilisation northward is well known. The important fact is that the palace of Knossos has four entrances corresponding to the cardinal points, and the same arrangement is observed in the palace of Phæstos.

This orientation and the regular disposition of the apartments, which are all at right angles, establishes a resemblance between the terramare, the pile dwellings, and the fortified camps of the Roman legions with the Cretan palaces. Whatever may be the view of the archæologists, the agreement between buildings so far apart and so remote in point of time is very suggestive, and a comparison should be fertile in results.

s Brizio, Monumenti Antichi, R. Accademia dei Lincei, vol. i. p. 250.

2 Pigorini, "Terramara di Castellazzo Fontanellato, Notizie degli Scavi," Lincei, 1895 . 
V.

On entering the central court I walked round the chambers on the northern side, and visited the rooms which served for the guard and some others, where many frescoes, now removed to the

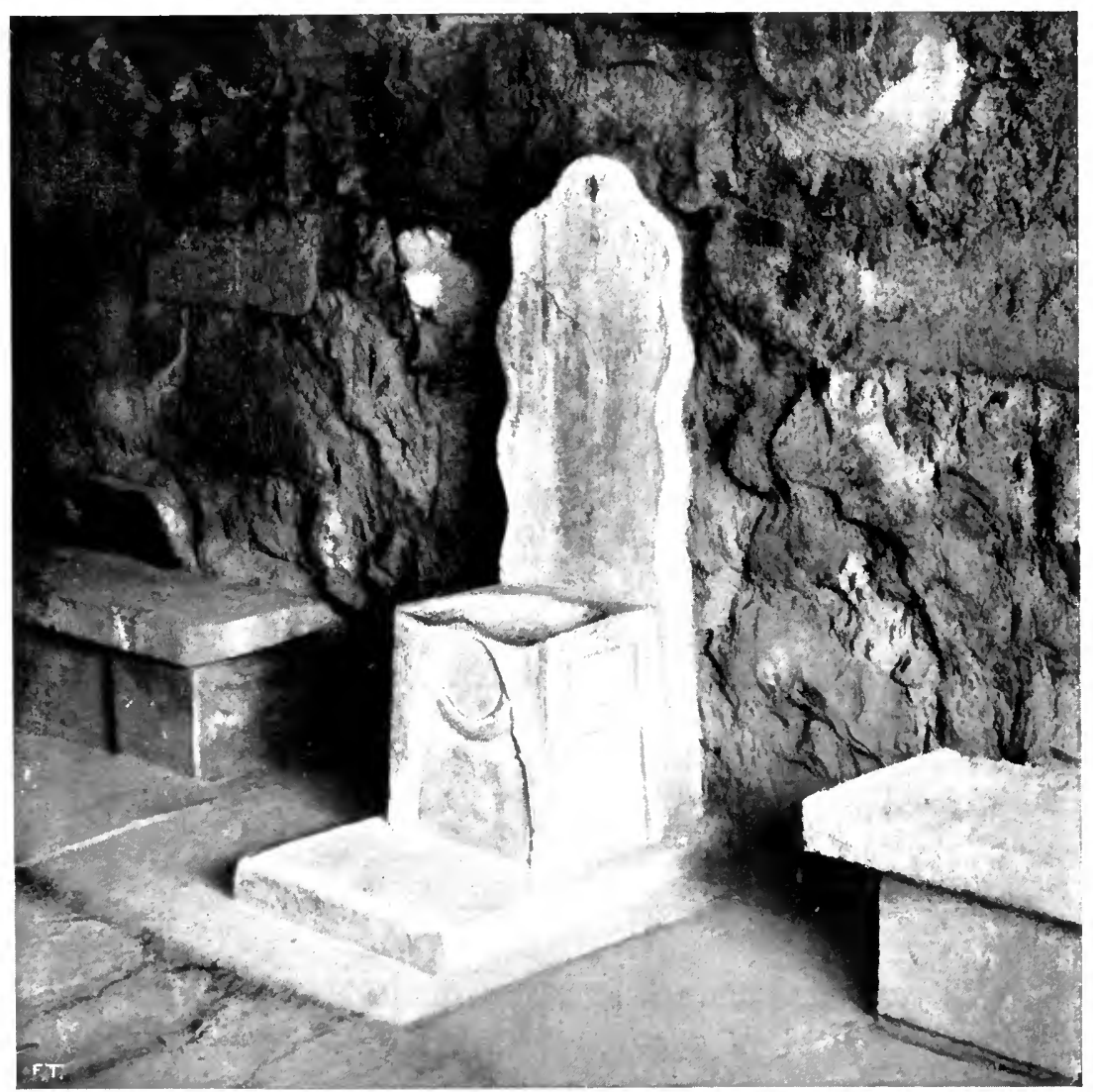

FIG. 53.-THE THRONE OF MINOS.

Museum at Candia, were found. Among the great blocks of gypsum there are lying on the ground broad limestone slabs with pink and darker-coloured veins. The slabs of alabaster with which the walls were faced are taller than a man, and it is only just possible to touch the edges with arms outstretched to the 
utmost. But the rain is destroying them rapidly, as may be seen by the vertical channels by which the water from the upper floors runs off. The Pentelic marble is fine, the veins are, however, too regular and parallel, but the light transparency of the ivory-coloured alabaster renders it a decorative material of great charm. The impression produced by the court is imposing, 1 and its chief attraction is the throne-room, which is to the right of the northern entrance. A few steps lead down to the antechamber, which is surrounded by alabaster benches, and in the midst is a great basin of red limestone resembling porphyry. The throne-room is separated by three columns from the part already described, and against the wall is a bench (Fig. 53).

The throne of marble is formed like a handsome wooden chair, such as would be used at the present day, but perhaps more comfortable. The seat is hollowed out to fit the person, and the back is also hollowed to suit the shoulders and make it convenient for leaning back. Round the edge of the back is a beautiful and slightly undulated moulding tending to a Gothic style; at the lower part of the seat are two interlaced arches in Mycenæan style and it was entirely painted a vivid red.

Dr. Evans says that this throne is the most ancient now known in Europe. I stood long in contemplation before it repeating Dante's lines:

"Stavvi Minos orribilmente e ringhia;

Esamina le colpe ne l'entrata

Giudica e manda, secondo che avvinghia."

VI.

The ground slopes down towards the valley, on the eastern side of the court, and here I had the pleasure of being able to descend by a Mycenæan staircase with steps as broad and easy as those of the palaces of the Renascence. They led past the two floors of the royal apartments, and traces of steps are seen ascending higher towards the apartments looking over the courtyard.

I It is $5 f$ metres long, 24 wide, and paved with great slabs of limestone. 


\section{I22 PALACES OF CRETE AND THEIR BUILDERS}

We owe a debt of gratitude to Dr. Evans, who has rebuilt this part of the palace. He has succeeded in two objects, one which was urgent, to save from destruction the ruins which have been discovered, the other, of allowing us to see complete the architectural details which it would be difficult to reconstruct in imagination while the timber was wanting.

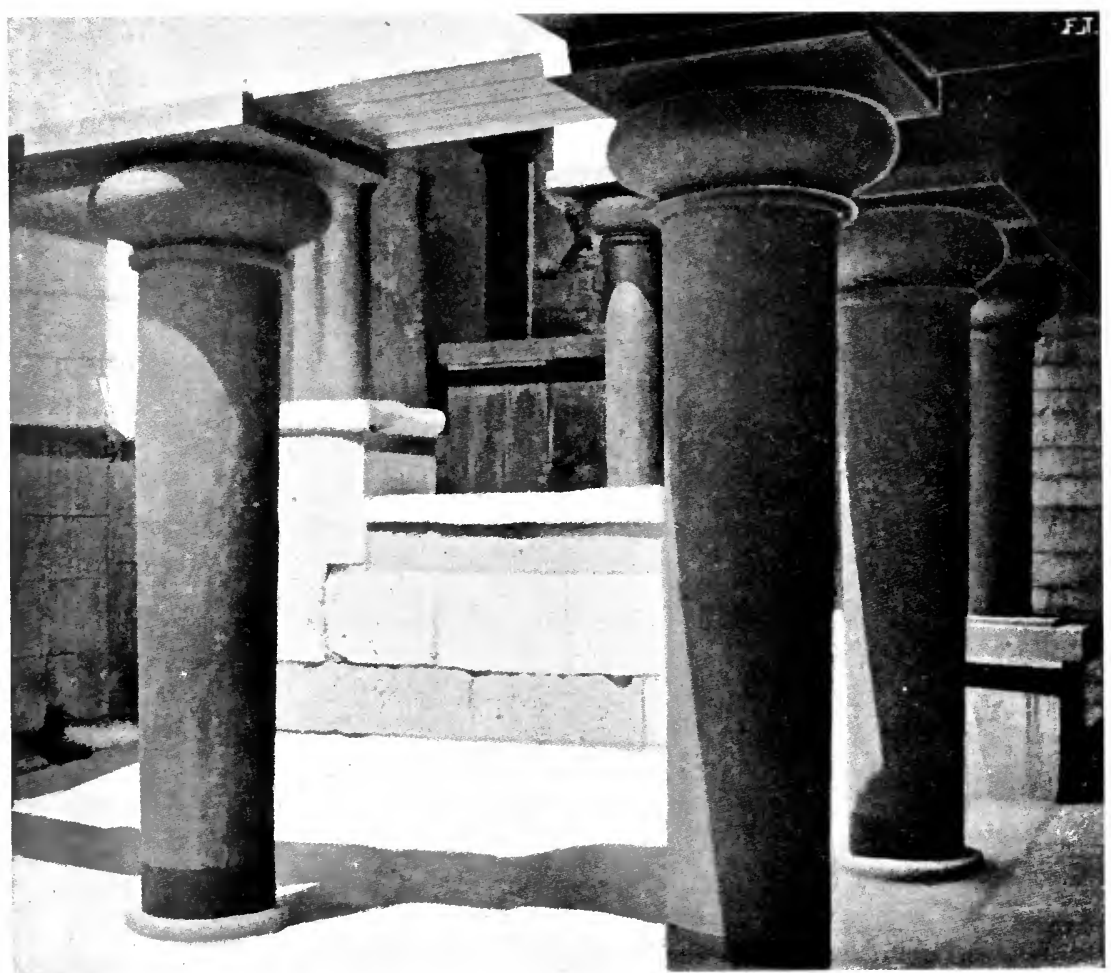

Fig. 54.-ENTRANCE TO THE GROUND FLOOR BY THE STAIRCASE OF THE PALACE OF KNOSSOS.

In Fig. 54 the distribution of the columns and walls for the formation of the grand interior staircase of the palace is shown. ${ }^{\mathrm{I}}$ This is the ground floor whence the staircase leads to the upper floors. Here, as in the palace of Phæstos, the architects lighted

I A Evans, "The Palace of Knossos," Annual of the British Sctool at Athens, No. xi., 1905 . 
the rooms built against the hillside by means of small courts surrounded by columns. In the rectangular space which Dr. Evans calls the queen's apartment there are four of these courts. I returned several times to admire this corner of the palace of Minos, which Dr. Evans has prepared as a pleasant recreation for students of antiquity. It was a house of at least four storeys, and nothing like it is known in classical Greece. The steps, 60 centimetres wide and ro high, tell us of a people who loved comfort, and the whole palace was sumptuously decorated. Here was found the fresco of the two dolphins, an absolutely perfect painting. Rather less than life-size, they have the dorsal and pectoral fins correctly placed, a wavy line of yellow separates the upper part of the body, which is blue, from the white under part. Two mullets with their great scales of light red complete the picture, while corals and algx spread their branches in the background. The Pompeian style of decoration, in which the artist extended the perspective by the introduction of landscapes and marine views, finds here its earliest manifestation of pictorial illusion.

\section{VII.}

I ask the reader to forgive me if I look with more admiration on a certain latrine in the queen's apartment (marked W.C. on Plan II.) than on the throne of Minos. In a little room, lined with alabaster, was a wooden seat, 57 centimetres in height from the pavement, while beneath the latrine passed one branch of the sewer.' I saw another less handsomely appointed in the palace of Phæstos. To us hygienists these are two memorable points of excellence.

A cheerful note is sounded by the olive press discovered near the queen's apartment. This shows that the peasants lived beside the princes, and that the work of the fields was

I Specialists who desire further particulars will find the plan of the sewers in two sections in the report of the excavations made by Mr. Arthur Evans in 1902 . The sewer is marked by dotted lines on the left side of the plan, Plate II., and passes through w.c. 
an honourable occupation in which all took a part. There were artists also living in the palace. This is proved by the fact that an amphora was found with the design scarcely sketched out by an alabaster tool, and hard by was a great alabaster vase like those which form the chief ornament of the palace of Knossos. These are great vases sloped and bellied out, with a flange at the bottom by which they could be fixed in the ground or lifted on to a tripod. On the cover and round the body are bands of very minute design in low relief.

Well worthy of a visit are the magazines, but they are more like a gallery for the treasures of a prince than a granary, a cellar, or a store-room. I pass over the magazines at the N.E. of Plate II. and stop at the great magazines indicated at the upper part of Plate I., where Dr. Evans found eighteen long, narrow rooms opening on to a long gallery and containing great oil jars or pithoi, marked with a small circle in Plate I. I The great vases in terracotta bear a serpentine decoration or simple bands of clay worked with a chisel in imitation of the metal belts. All have bent handles above and below (Fig. 55).

One thing which specially attracted my attention was the double structure of the walls. The exterior was made of great blocks of gypsum, but instead of being placed near enough to touch each other, they were left a metre apart and joined by strong cross beams of timber fixed in the dove-tail mortise holes which are seen in the blocks ${ }^{2}$ (Fig. 56). This intramural space filled with rubble is supposed to have been made either for economy, or in accordance with tradition dating from a time when building in wood was general and blocks were bound together by cross beams of timber.

The fact, however, that both here and at Phæstos the walls of the magazines are thicker than the rest suggests another explana-

I In room I 2, for instance, there are twenty-five pithoi.

2 The block to the right in the photograph is $3 \mathrm{~m} .20$ long, $1 \mathrm{~m}$. 10 , high, and 0.50 broad. Another is $4 \mathrm{~m}$. long, I m. high, and $70 \mathrm{~cm}$. broad. 


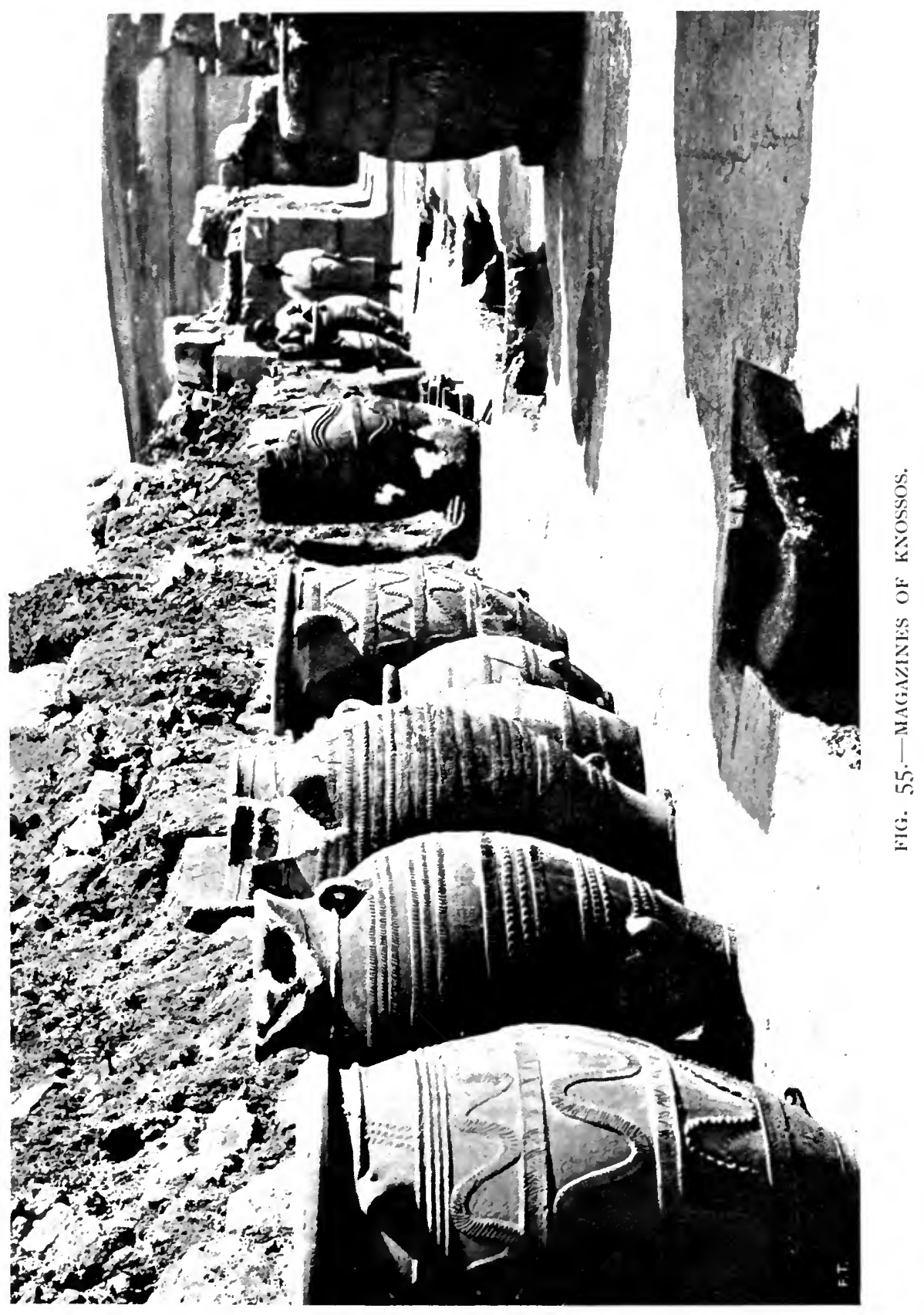



tion. The extravagance of the great blocks and of so great a thickness of wall in the case of a building only a few metres high must in my opinion have been with the object of keeping the chambers of the magazines cool and dry.

The divisions, too, between the cells are very thick, which is unusual in ordinary building--some are as much as 2 metres (Fig. 57). This was not a mistake of the architect's or waste of material. We have, in fact, here an example of the technical perfection of Mycenæan building, in the protection of the maga-

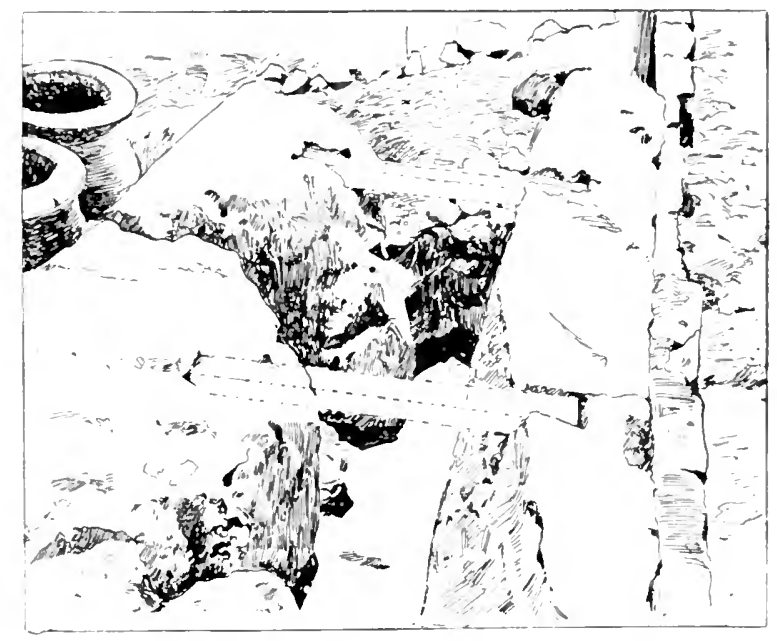

F1G. 56.-DOCBLE WALLS BUILT OF LARGE BLOCKS CONNECTED BY WOODEN STRLTS.

zines by means of these walls from the frost of winter and the heat of summer.

The great blocks of alabaster resemble petrified sponges full of sharp-edged cavities. The weather dissolves the soluble lime and gives the stone a cinder-like and broken appearance similar to that of rocks beaten by the waves.

\section{VIII.}

Another thing which attracts attention in these magazines is the series of cists, called by the peasants Kasséles, in the pavement. 
The room in Fig. 57 shows seven on the left; there are others in the centre of Fig. 55. These are a sort of cist closed by a wooden cover, and inside were vases, leaves of gold, or objects of porcelain and bronze. In the central corridor (Plate I.) are twenty-seven cists in a row ; they appeared to be storing-places for objects of value. ${ }^{\mathrm{I}}$

The management must have been modified after the destruction of the first palace, for the use of these cists, of which there are more than a hundred, was given up, and no more were made; but these are historical problems which later excavations must settle. Meanwhile we are confronted with the question of the use of these very complex magazines. If they were for the stores for the use of the prince it would have been more convenient to keep them in a few larger rooms. The way in which they are divided up suggests that they were used by different persons. They are built in too costly a manner for a store-room for food.

I cannot believe they were intended for this when I see the handsome adornment of the walls with pale yellow alabaster slabs veined with blue and rose, or we should have to admit that this was a magnificence of decoration unknown in any other age. Some of the stones in the magazines are coloured in delicate streaks like onyx, and when they were smooth and bright must have produced a wonderful effect.

I had an idea that these might have been a sort of bank where the prince caused the property of his wealthy subjects to be deposited. Possibly the office was in room 18 , for in it was found a collection of written tablets. At Delos, which is connected by many memories with the Cretan civilisation, and at Olympia, also celebrated as one of the most important religious centres of the Hellenic people, the temples served as banks. ${ }^{2}$

I Some are I m. 70 deep and $77 \mathrm{c.m}$. wide, others I m. 20 and to centimetres wide, all are little less than a metre in length. In the plan these cists are not indicated, as they were not discovered till after the plan was drawn.

2 C. Diehl, "Excursions archéologiques en Grèce," p. 167. 
I asked Mr. Evans if there was any objection to the hypothesis that the vassals deposited their valuables in the prince's palace. He answered, smiling, "It is possible."

The richness of the magazines and their great extent in comparison with those of Phæstos give reason to the belief that here was the capital of the kingdom; in fact, similar cists are not found either at Phæstos or elsewhere. The study of the private chests, to give them their modern name, makes it appear that personal property was much divided. Allowing that each

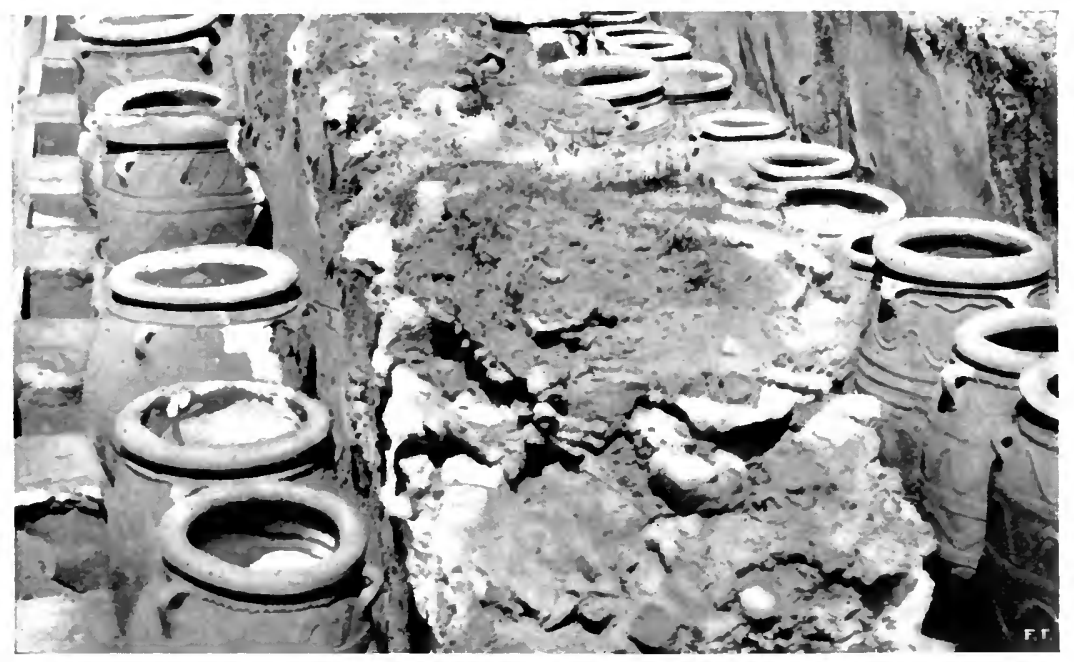

Fig. 57.-DIVIDING WALLS OF THE ClLLS IN THE MAGAZINLS OF THE P.ALACE OF KNOSSOS.

of the richest citizens possessed a chest, there would be more than a hundred wealthy proprietors, and we may reject the idea of there being landed proprietors in Crete. Other facts tend to confirm a similar conclusion. In Greece, even in the most liberal States such as Athens, numerous restrictions prevented the accumulation of property, and it is reasonable to believe that similar restrictions already existed in the remote period of Minoan civilisation. 


\section{MR. ARTHUR EVANS'S CHRONULOGICAL CLASSIFICATION.}

To establish the chronology of the monuments discovered in Crete Dr. Evans relies on the study of Egyptian antiquity, and his classification is indispensable for the comprehension of Minoan and Mycenean civilisation. ${ }^{\mathrm{I}}$ The history of Cretan monuments is divided into three periods and each of these into three divisions. The last period corresponds with the time of the greatest diffusion of Mycenæan culture. The great catastrophe which destroyed the second palace of Knossos was in the middle of this last period. The affinities existing between the paintings of Knossos and those of the XVIIIth Dynasty in Egypt prevent us from fixing the date of the destruction of this palace beyond 1500 B.C.

In the first period the remains and the vases are immediately above the Neolithic level, in which bronze is unknown. In the second period polychrome vase painting came into vogue, and vases were decorated in orange, vermilion, or white with angular and spiral geometrical designs on a black ground. The vases found at Kamares belong to the middle of the second period. In the third part of this period ceramic polychrome is in decadence; orange, vermilion, and carmine are less used for the decoration of vases, and white decoration on blue, violet, or mauve ground with spiral designs became popular. From these developments in ceramic art in the middle period it will be understood how long a space of time is involved.

Vases in the Mycenæan style do not appear till the third period. This is the time during which art reaches its highest level; and from Crete civilisation radiated over the islands, over Greece and Italy. At the close of this period begins the time of decadence in the Isle of Crete when Mycenze reached the apogee of her greatness.

Some objections have been made to the use by Dr. Evans of the personal name Minoan to indicate a period of several centuries. But the difficulties which faced him must be considered. The chief difficulty was an ethnographic one. If he had entitled the early history of Crete Pclasgic the title would perhaps have been correct, for it seems to be a fact that the Pelasgians crossed over from Crete into Greece and then came to Italy. This, however, is probable but not certain. Dr. Evans preferred to keep neutral on the question of the origin of the Cretans, a subject on which discussion has already been somewhat heated. In the uncertainty whether this people was Pelasgian or Achxan, whether they came from Asia Minor or Libya, Dr. Evans chose the name of Minos as the most celebrated king of Crete to indicate the long period of time which precedes Grecian history.

I shall apply the term Minoan to the age which preceded the tombs discovered by Schliemann, and Mycenean to the things belonging to this last period of the pre-Hellenic age.

I A. Evans, "Essai de classification des époques de la civilisation Minoenne," I 906. 
This is a slight deviation from the terminology established by Dr. Evans, and I follow this plan to aroid giving up at once the whole Mycenaan tradition with which the Bronze Age comes to an end and the age of iron begins.

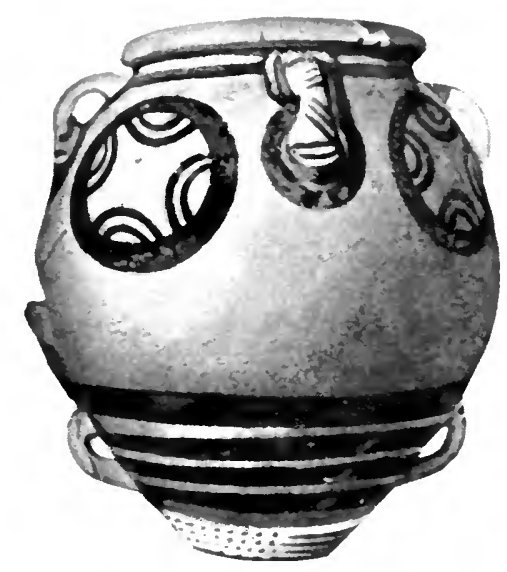

FIG. 59.-KAMARES VASE FOTND IN THE FIRST PALACE OF KNOSSOS 


\title{
CHAPTER VI
}

\author{
DRESS OF THE WOMEN
}

I.

FASHION in feminine attire is the costume of other times reproduced and modified according to the taste of the moment. I think every one will admit that there is little left to invent. The new fashion design is one that is old enough to have been forgotten. Nevertheless, I could not have imagined before I entered the Museum of Candia that four thousand years ago women dressed in the same mode and wore the same hats as fashionable ladies of to-day.

In the time of Pericles artists idealised woman to so great an extent that they clothed her in a style quite different from that in common use, and draped the statues of the goddesses in the temples and of the women on the grave stelai according to their own fancy, so as best to display the outlines and charm of the body. ${ }^{I}$ The fact that no embroideries appear on Greek statues, when we know that they were very generally worn, is in itself enough to show the tendency of the classical style. Draperies and anatomical forms were the basis of sculpture, all the rest was subsidiary.

Modern French art resembles more than any other the primitive art of Greece. What the Greeks and Romans painted had a grave and austere quality which is entirely absent from the frescoes of Crete. There are fashion plates of modish women

I For the classical chiton see Chapter XII., Fig. I I 4 . 
with noses that have not yet developed into the Grecian type, full busts, tight stays with a slim waist; and from the waist downwards they have modern petticoats with fantastical flounces, trimmed with crossway and straight bands, with great profusion of embroidery.

An unusual vivacity is shown in the fresco paintings, statues, and pottery ; the figures have a sprightliness of movement which has nothing in common with the rigid and formal gestures of Egyptian art. There is a characteristic license in the freedom with which the faces are treated. The hieratic style of archaic sculpture and the calculated harshness of primitive art will be sought for in vain in the meridian of Minoan art.

\section{II.}

Fig. 59 shows the type of the women of Knossos. I The large eyes, rosy lips, the dark hair curled on the forehead, and the waved locks on the shoulders, give to these figures a piquant flavour of modernity. This figure shows a dress of blue stuff with red and black stripes, standing out at the back of the neck, and flowing downwards. The colour of the skin shows through the red and blue stripes of the chemisette of fine veiling, adorned with ribbon rosettes.

It recalls the charming figures which Watteau painted in the picture, "The Departure for Cythera," and there is, in fact, a certain resemblance between the Mycenxan style and that of the celebrated French artist.

Certain fragments of plaster found at Knossos and skilfully put together by M. Gilleron, the French artist, are a marvellous example of a wall decoration of painted miniatures, unequalled among the monuments of any other nation.

These people were incomparable artists in the great freedom with which they treated complicated scenes, as, for example, in the picture of the crowd of spectators in a religious ceremony. The women's hair is dressed with little curls on the forehead and

I Evans, "The Palace of Knossos," I900, p. 57. 
their back hair falls in waves. They wear a ribbon across the brow, it is the fillet which we find later on the heads of the goddesses of the classical period and in the tetradrachms of Attica and Syracuse. These scenes, which will shortly be published by Dr. Evans, show us the private life of the women.

Among the Athenians it was contrary to good form for women to appear in the streets or in public places, but here

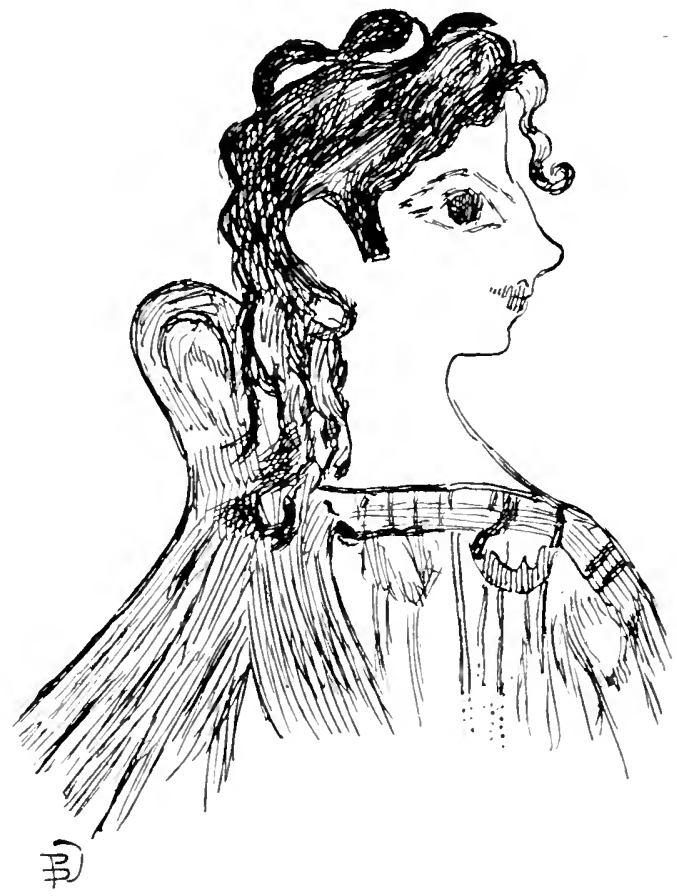

FIG. 59.-FRESCO FROM KxOSSOS.

women are present on all festive occasions. In front of a temple they are grouped under the trees in animated conversation; they have white skins and the men are dark, in accordance with the conventions of Egyptian and Etruscan painting. Some hold out their hand in salutation, others stand looking out of the windows, all have large eyes and tresses of wavy black hair falling on breast and shoulders. The artists have given these women slender figures and little up-turned noses, with roguish faces and 
audacious eyes. The technique indicates a highly developed school; the voluptuousness of the full red lips, or the pupil which glances at one out of the great enticing eye, or the perfection of the bosom beneath the transparent chemisette being expressed by one stroke of the brush.

III.

The monuments of Crete add nothing to the variety of fashion in dress. This is strange when we consider that the period of the history of the Mediterranean basin has been doubled in duration by these excavations. Even the skirts made like wide trousers, now worn by women in athletic games, were there already. We see them in the designs on the seals and in Fig. 62 .

Feminine attire is so characteristic an indication of the civilisation of a people that that alone would be enough to indicate the artistic taste of a period. The fashion often changed, but there is nothing resembling the exaggerated headdresses and magnificent garments worn by the châtelaines of the Middle Ages, or the puffed sleeves of the Renascence.

The style of hairdressing of the women, very complicated in an early stage of society, tends to become simpler as artistic taste improves, and again becomes complicated in the decadence of a civilisation. We see this in the Mycenæan age, the latest period of Cretan civilisation, when spirals of gold, diadems, and rings were worn in the hair. The same thing happened in Rome. The busts of the empresses in the Capitol are instructive, and their fashion of hairdressing is useful as a guide to the chronological classification of statues. The close relation which exists between women's dress, architecture, and furniture is seen in the rococo period, when the clothes and wigs of the women were of the oddest fashion. This is again seen under the French Revolution and the First Empire, when women's dress and the decoration of houses and furniture were inspired by Greek and Roman models. 


\section{IV.}

The terracottas, frescoes, and statues of Crete afford opportunities for the study of the evolution of feminine attire. From a collection of ex voti found in a little temple at Palaikastro we can prove that the fashions of four thousand years ago differed very little from the present modes of Paris. And not only were the shapes of the hats and garments the same, but the spirit of fashion was the same also.

The hat is made with a wide, turned-up brim, and is small at the back, three white ribbons are passed across the front and are crossed behind. I saw one hat with the brim turned up in the shape of a funnel, in the midst of which was a flattened crown, just as they are worn to-day.

Mr. Myres, in describing these terracottas, ${ }^{\mathrm{I}}$ mentions simply " modern hats in the fashion of Petsofa."

Other hats have a narrower turned up brim, with three tufts or rosettes round the front, and the edge of the brim is undulated. At a later date these hats appear no longer, and the women prefer the simple adornment of curled and crimped tresses. And the artist drawing the eyes in black on the terracotta always exaggerated their size. (This is the eternal type of female beauty which will never change.) The long petticoats in a pattern of white check on a dark ground, and also the designs of Scotch tartan, were already worn. Some of these ex voto figures of women are completely nude, and a few are wrapped in a mantle fastened by a girdle, but with the breast uncovered, though the mantle is fastened.

\section{V.}

Dr. Evans found at Knossos two faience figures, one of which is unfortunately headless. They have upraised arms, and hold small serpents in their hands, and are perhaps priestesses.

"Myres, "Excavations at Palaikastro, II., the Sanctuary Site of Petsofà," Annual of the British School at Athens, vol. ix. p. $37 \mathrm{I}$. 
The characteristic of their dress is that the waist is very small-probably produced by stays. The sleeves are very short, and the decolletage in front very wide, showing the bust (Fig. 60). A very similar style of dress is still found among the Cretan peasants. The women of Anoja on Mount Ida wear the chemisette half open.

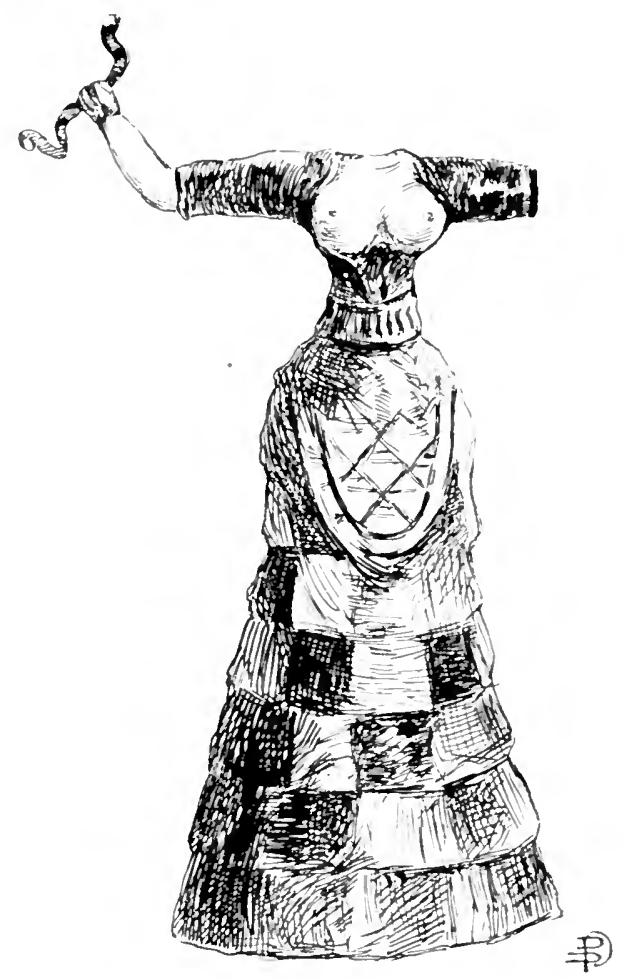

FIG. 60.- PORCELAIN STATUETTE OF A P'RILSTESS FOCND AT KNOSSOS BY DR. liNANS.

The bodice is laced in front and the belt is possibly of metal, as it has a projecting edge. The hair falls loose on the shoulders. On the wrist of the right hand is a bracelet. The colour of the jacket is dark orange, with purple ribbons; the rest of the dress is light in colour and the flounces have alternate bands of dark purple and light. A rounded apron embroidered in a design of lines crossed in a lozenge pattern is worn in front and behind. 
The dress below the belt has seven flounces in chess-board pattern. Here the squares are plain, but in other figures there are two dark-coloured vertical bands on the light squares and none on the black ones.

The skirts are mostly very smart and quite modern in style, with flounces of white, red, and blue in plaits, or with horizontal and vertical bands. At the hem a Greek rectangular design forms a deep border. The tight belt with the wide hips give the women a very different outline from the large-waisted Greek statues.

The modern Catholic custom of bringing to the churches garments for the Madonnas as ex voti was already in vogue in the religions of antiquity. Here (Fig. 6I) we see the dress prepared to be hung up in the sanctuary. I have omitted the body, which was plain, and show only the skirt, embroidered with crocus flowers. This was one of the motives most frequently drawn both in Crete and in the Cyclades, and especially at Melos. Dr. Evans notes that the two wavy arched lines of the skirt have a distant resemblance to the designs of Gothic art.

The form of devotion of which we see here one of the most ancient manifestations passed into Greece, and enormous sums were spent on these dresses At Sybaris a himation was sold to the Carthaginians for 120 talents, which corresponds to about 675,000 francs. The himation was a great mantle which covered the whole person, as in the statue of Sophocles in the Lateran Museum. The maidens of Attica used to weave an artistic peplum for the statue of Athena in the Parthenon every fourth year. Needlework was at this time much more in use than in classical Greece, for in the Minoan age the fibula did not exist. Even in the tombs and excavations of Mycenæ which mark the latest period of this civilisation there is no form of fibula, but only large gold pins tastefully worked. One in the museum of Athens bears a figure of a woman resembling these priestesses with the serpents. In the Odyssey the peplum which Antinous sent as a gift to Penelope had twelve fibulæ of gold ${ }^{1}$; this

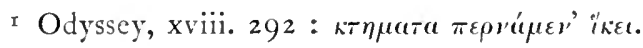


shows how much the fashion of making dresses had changed in later days.

Egyptian women have quite a different style of hair-dressing and wear garments fitting closely to the body, so that from the girdle downwards (either on account of the transparency of the stuff or the division of the dress) the whole of the leg and the profile of the body is seen. From their dress we recognise the elevated position of the Mycenæan woman, who, though she uncovered her bosom, did not uncover her legs in public.

The open chiton, which left one side bare from the shoulder to the heel, the upper part of the chiton being fastened only by a clasp on the shoulder, only appears during the moral corruption of classical Hellas. The merreilleuses wore it when Grecian fashions were revived in France, but the opening was then only from the waist downwards.

\section{VI.}

The prevailing colours in the women's attire are yellow, purple, and blue. The flowers of saffron were used in dyeing veils, mantles,

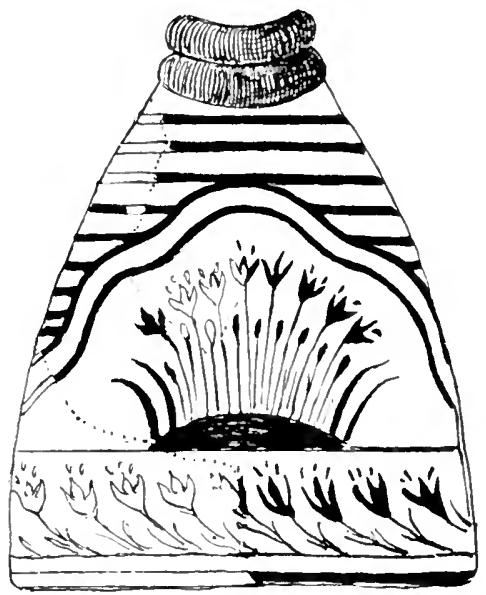

FIG. 6I.-SKIRT OF AN E.I TOTO DRESS FROM A SANCTUARY AT KNOSSOS. and leather. Among the frescoes of Knossos is a painting of a vase of the same shape as the brass pots in which the women of Subiaco or Otricoli carry water on their heads; the handles, too, are the same; in it are crocus flowers growing and a man's hand is in the act of gathering them. No one will now assert what philologists once believed-i.e., that the Phœnicians brought saffron to the Mediterranean. Crócos is said to be an Oriental word, but zafron is Arabic, and if etymology were proof, we should have to believe that the Arabs brought it to us. In Roman times it was used as a perfume, but 
now taste has altered and we only use it in risotto. I recall the lines of Virgil on the crocus and purple, the two colours most in vogue. ${ }^{\mathrm{I}}$

On some bronze Mycenæan vases we find an incised design of crocus flowers which resemble the flowers of the Colchicum autumnale, so common in Italy. In Homer's description of a poetic scene on Mount Ida "the flamy crocus made the mountain glow." 2

Goddesses, nymphs, and queens were clothed by the Greek poets in the hue of saffron, and yellow, too, was the mantle woven by the maidens of Athens for Athene. The woman of the Bronze Age, though less civilised than modern woman, was in some respects less of a savage, for she wore no earrings.

\section{VII.}

Small sprays of gold leaves were used to adorn dresses, and were appliqué upon the stuff; there are myrtle leaves with the stalk woven in among the threads of the material.

Later on dress becomes more complicated. I reproduce a fresco from Hagia Triada (Fig. 62), which has been drawn in colour by Stefani ; it represents a woman, life-size, rising from a seat. Unfortunately the upper part is wanting, and the remainder is somewhat blackened by fire.

Halbherr thus describes it:3 "The dress is a very rich Mycenæan costume, consisting of a pair of wide trousers of blue material dotted with red crosses on a light ground. Half-way up the thigh, from beneath a white border edged with purple and embroidered with small recurring rings in the same shade, fall two waved frills, with white, red, blue and dark bands. The trousers end half way down the calf, and have the same trimming of frills and furbelows. The rest of the leg and the foot appear bare, and this is also confirmed by the light colour in which they

I "Vobis picta croco et fulgenti murice vestis" (Æn., ix. 6I 4 ).

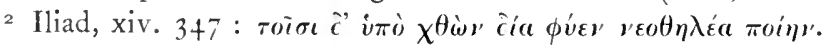

3 Halbherr, Monumenti antichi, R. accaa. dei Lincei, vol. xiii. p. 59. 
are represented - the conventional flesh tint used for women in the Mycenaan frescoes. The torso was perhaps partly covered by a tight-fitting chiton or by a light-coloured corset ornamented by stitchings - at least, so it seems from the upper extremity of the fragment."

\section{VIII.}

In a small apartment near the throne-room (Plate I.) ${ }^{1}$ were two stone seats, which show the attention paid by the Mycenæan artisans to anatomy in the construction of furniture for ordinary use, the seats for men and women being differently shaped. Fig. 63 shows part of this room. This stone, I 3 centimetres in height from the ground, served, as may be seen from its shape, as a seat.

If this seat be compared with that which is preserved in the so-called throne-room and with a second in the hall of the tribunal, to which I will return later, the difference in the form of the gluteus muscles (to use the anatomical term for the part which is used in sitting) is apparent. 'The hollows in the seats for men are narrower and deeper, for women they are wider and shallower. The seats for men

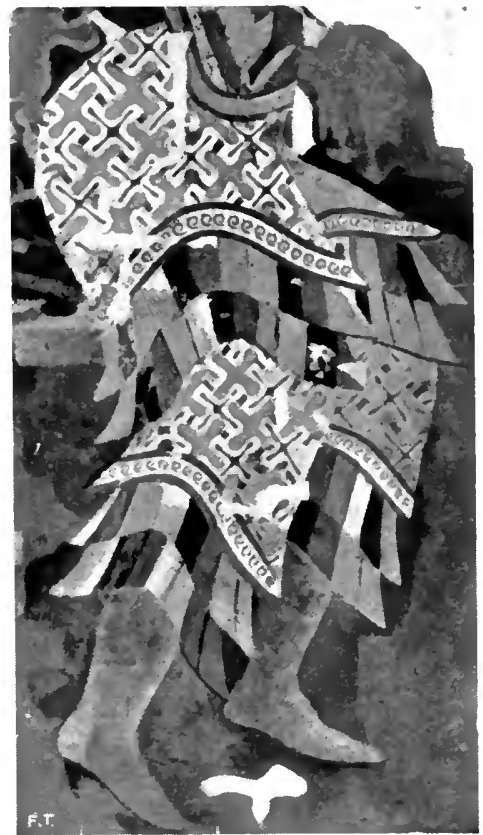

FIG. 62.- FRESCO FROM HAGIA TRIAIDA, WOMAN WITH PARTICOLOCRED AND EAIBROIDERED DRAWERS.

are as high as ours, for women they are as low as hassocks. The terracotta ex voto figures of Palaikastro and Petsofa, of which I spoke in the beginning of the chapter, are seated on little white stools.

${ }^{1}$ Behind the throne-room a door bears the inscription by Dr. Evans : "Room of the Plaster table"; the other woman's seat is in the lower room, "Room of the Lady's seat." 
In front of the seat a low table of cement has two hollowsone half spherical in shape and the other oblong-and, like the seat, it is fixed in the cement of the floor. Doubtless this table served for the work of the person who sat by it. To the left is a longer table, also low and made of cement, with a circular hollow in the middle.

Possibly this was a room where garments were made: it must certainly have been a room for the women, for at the end of the corridor in this apartment there is a similar seat, and probably the low table which I have described in the room of

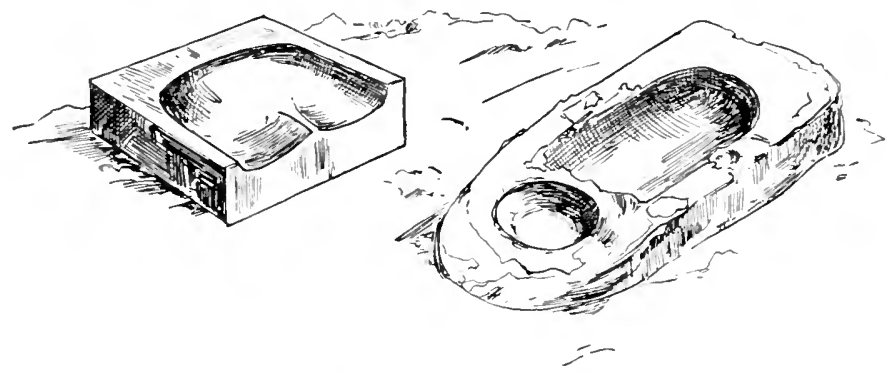

FIG. 63.-WOMAN'S SEAT AND WORK TABLE.

the forewoman seamstress served for her apprentices. If it had been a kitchen the tables would have been made of stone.

IX.

All writers have agreed that the Phœnicians invented purple and carried it about the Mediterranean. This is another error of the philologists, who trusted too much to Homer. Odysseus and Telemachus had, like other heroes, a mantle of purple; and carpets, leather, and ivory were frequently dyed purple by the women of Meonia and Caria. ${ }^{I}$

In the villa of Hagia Triada and elsewhere vases have been found bearing a design representing a net and shells of the murex, whence was extracted the purple dye. We know from Pliny 2

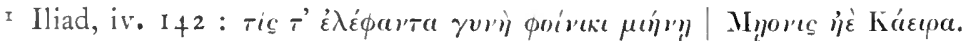

2 Pliny, ix. 6r. 
that these shellfish were brought up from the sea in fishing nets, and he says that they have usually seven spines; in the Cretan vases we see seven spines indicated on the shell of these molluscs. At Kouphonisi (the ancient Leuke) Mr. Bosanquet found a bank of murex shells with Kamares I vases close by. This proves that in Crete the manufacture of purple was earlier than the Phønician

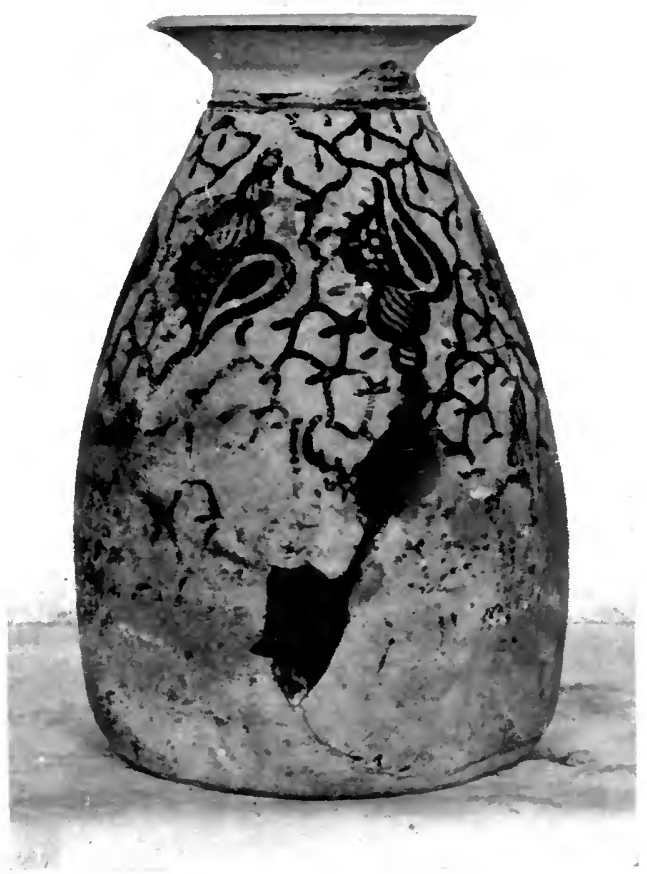

FIG. 64.-VASE WITH IDESIGN REPRESENTING A NET WITH SHELLS OF THE MOLLUSC FROM WHICH THE PURPLE DYE WAS OBTAINED.

civilisation. At Palaikastro, too, deposits of murex were found near vases of the middle Minoan period.

This year I fished up a number of shells of Murex trunculus in the port of Candia and on the shore near by. I put them on a dish and collected some drops of purple, which the animal

x Bosanquet, "Some Late Minoan Vases found in Greece," Hellenic Studies, xxiv., 1904. 
exudes like a tear. In the Mycenæan vases the tentacle which the fish draws in in order to close the shell is shown; when it is tranquil the murex moves like a snail. Pliny says that purple was extracted from several kinds of shellfish shaped like the triton, and describes the preparation of this dye in leaden vases.

When I examined the cists in the magazines of Knossos I found that some of them were lined with lead. This gave me the idea that these cists might have been used for the preparation of the purple dye. Sidon and Tyre certainly derived the purple industry from Crete or from some other isle of the Ægean, for the deposits of murex shells at Palaikastro, judging from the pottery found among the shells, must date at least as far back as the middle Minoan period, at least two thousand years before the Christian Era. At that time the Phœnicians had not begun to trade in the Mediterranean. ${ }^{1}$

With the purple dye many gradations of colour were prepared, shading from deep violet blue to blood red, and it was a fast colour unaffected by washing or light. Sidon and Tyre had perfected the art of dyeing, but we can no longer admit that the Phœnicians were the inventors of purple.

I According to Beloch ("Griechische Geschichte," i. 73), the intercourse of the Phœnicians with Greece was not earlier than the eighth century B.c.

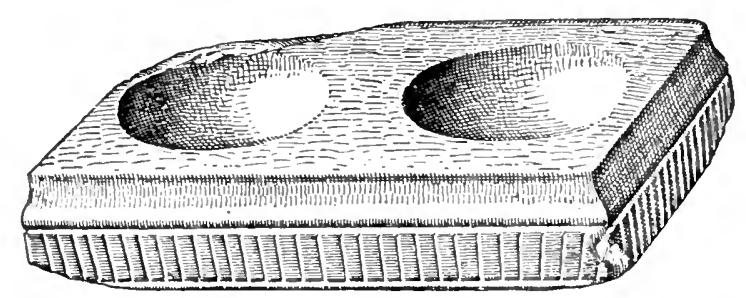

FIG. 65.-LIBATION TABLE OF STEATITE FOLNI) AT PHASTOS. 


\section{CIAAPIER VII}

THE CRAFTSMEN OF MINOS

I.

IF it could be proved that Minos never existed it would still 1 be true that a people lived in Crete who held the dominion of the Mediterranean and built magnificent palaces. With the help of archxology we can become acquainted with the social struggle and the life of the worker in remote ages. Even here, as ever, the humble who do everything have left very slight individual traces, and Cretan art appears as the sign of the power of the few who could dominate the mass.

I have studied the tombs of the poor in the Mycenæan age; I have held in my hand their bones and skuils, the necklaces of stone beads and the humble vases which they placed in their graves, but among all the objects found in these tombs those which most impressed me were the tools of a carpenter of Knossos ${ }^{I}$ (Fig. 66). His family had excavated the tomb with such care that that alone would testify sufficiently to the feeling of the dignity and high social position of the craftsman. First a great square trench was cut in the rock, and inside this, at a depth of 2 metres below the level of the ground, another smaller trench was cut I metre in depth. By the body were laid a saw, a chisel, and an adze, and the grave was covered with well fitted stones. All these tools are of bronze. In the same necropolis a sword, a

r Evans, "The Prehistoric Tombs of Knossos," Archeology, vol. lix. 
bow and arrows were found buried with a soldier; in the crafts-

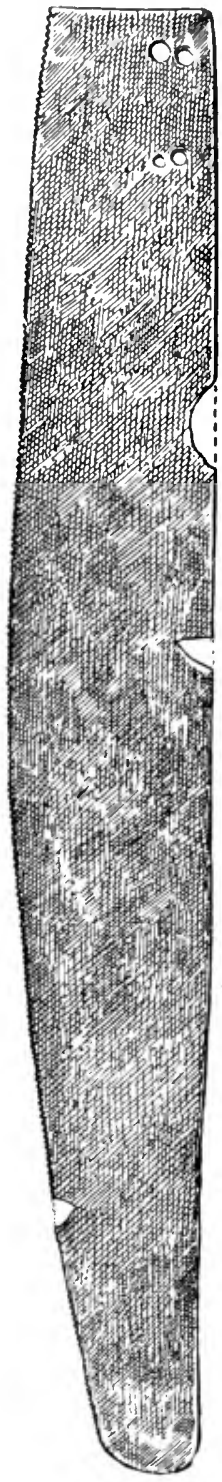

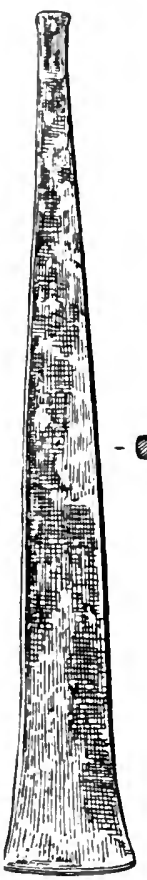

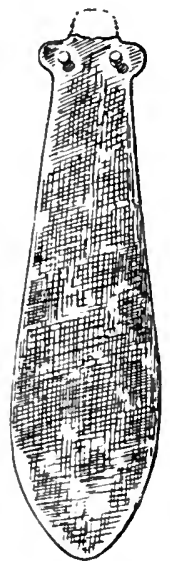
man's tomb were placed the tools of his trade.

A longer saw was found with tools of various trades in the villa of Hagia Triada. The bronze was very hard, for the marks of the working of the saw are visible on the limestone.

In a series of servants' rooms on the ground-floor at Phæstos there is in each room a recess which probably served as a small cupboard; in the four pieces of limestone which form the cornice of this recess every mark of the saw used in cutting the slabs of stone can be seen. Some enormous hammer shafts with two square openings which probably struck the anvil have their edge destroyed. This shows with what vigour these men worked. Manual labour was highly esteemed, and was more general than to-day among the dominant class. Odysseus records that he made his house and his famous bed himself, and was able to put together the beams and yards of his ship to make a raft on which he sailed the Mediterranean.

FIG. 66.-BRONZE TOOLS FOUND IN THE TOMIB OF A CARPEATER AT KNossos.

II.

On the eastern side of the palace of Phæstos Dr. Pernier found a furnace for pottery. It 
is of trapezoidal shape, and the walls, 1 metre in thickness, are covered with a layer of melted clay ${ }^{1}$ (Fig. 67). They are encrusted with a vitreous lava of a yellowish or dark colour, in some parts violet and shining.

It is a characteristic sign of Minoan times that close by the royal dwelling there was a humble potter's workshop. Besides the furnaces for common ware, there were other large ones for pots taller than a man. The amphoræ of elegant shape which

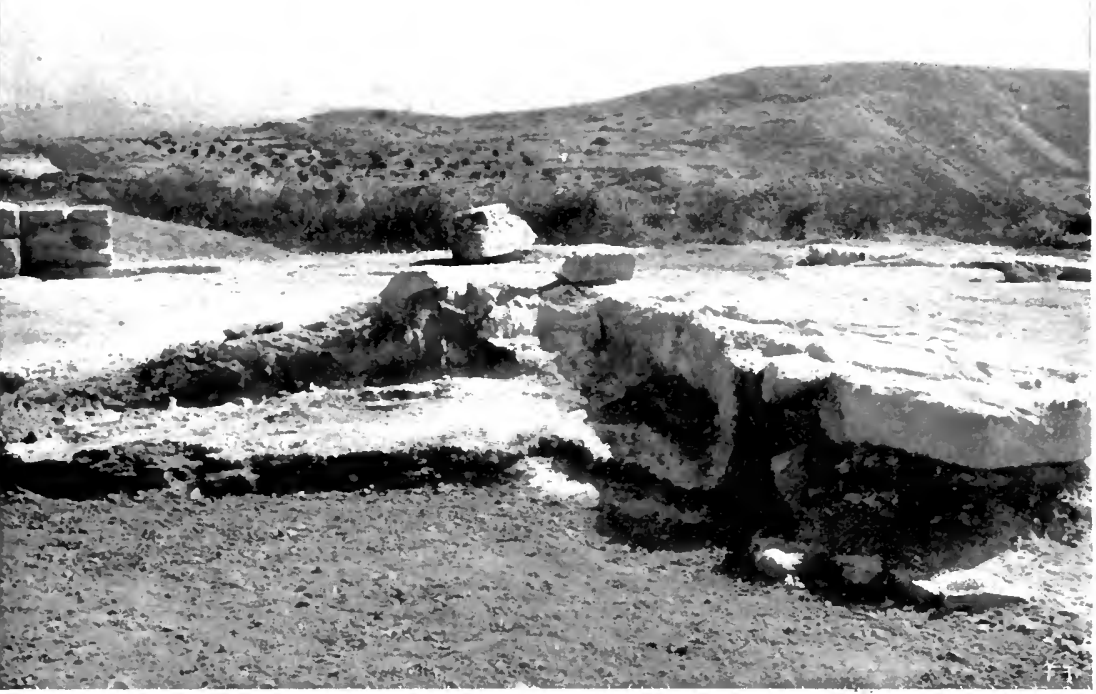

1.IG. 67-FLRNACE FOR POTTERT, I'HASTOS.

became a characteristic of Greek art were baked in these furnaces. This vase had a lid of terracotta, the handles were painted white, and the rest brown, round the neck were zig-zag lines in red.

I The wall at the bottom is 3 metres long. The mouth and one side are wanting. The two side walls were bent into a semicircle forming the sides of a triangle to the length of $1 \mathrm{~m}$. $70 \mathrm{c.m}$. Dr. Pernier thought it was a furnace for smelting metals, but after a careful examination we are convinced that it was only used for pottery. 
III.

We have several descriptions I of the private houses by Professor Halbherr, who discovered them at Hagia Triada, but ther were better class houses which probably belonged to officials of the princes. The humble dwellings of the labourers have disappeared because they were made of wood, while those of the

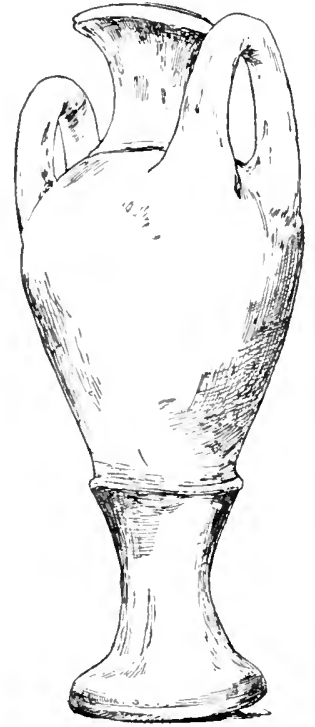

FIG. 68.- LARGE AN1PHORA OF TERRACOTTA FOLND AT P'HASTOS. middle class, being built of stone and timber, have been preserved.

Dr. Evans 2 found a great number of porcelain plaques in the form of houses. Timber was at this period the most generally used material for house building because the forests were abundant. Even at the present time wherever there are forests in the neighbourhood man makes use of the trees to build himself a house.

Trunks of trees were cut into blocks of the thickness required for the walls, the frames of the doors and windows were made of timber, and the empty spaces were filled with lime and plaster.

In these models the beams and slabs are faithfully represented. The windows are sometimes so near the side walls that these must have been made of blocks of wood. The palaces of princes differed in construction from the houses of the people in that the stones of which a palace was built, however carefully they were cut and joined with mortar, were never left with the surface exposed but always faced with plaster and coloured, and they appear to have differed little in the front or side view from our mediæval Italian houses. There is an indication of decoration on some houses where the blocks are simply marked out, and the structure

I Halbherr, "Mem dell' Istituto di Scienze e Lettere," xxi. p. 2 + I.

2 "Knossos Excavations," 1902, p. I 5. 
represented does not correspond with the actual building. Nearly all the houses have two storeys and in their colour must have had a certain resemblance to the villas of the Ligurian Riviera, being decorated with reit or white bands on a drab or blue or green ground.

The window frames and shutters are worthy of attention. The windows are divided by the framework into either three or four, like modern windows. There was no glass at that time; and the windows were probably closed by skins rendered transparent by oil. Some windows are red and perhaps had coloured curtains.

Judging from the attic windows which we find in most of the houses of Knossos, we may suppose that there was a terrace instead of a roof. We may exclude the idea of a double court forming two distinct dwellings for the men and the women (as appears to have been the case in the type of house described in the Homeric poems). I

Some of the porcelain models appears to be towers, as they have no windows or doors, or they may represent the side view of a house. Some have a projection resembling a chimney upon the roof. No one would have imagined that four thousand years ago the houses would have been like our own.

\section{IV.}

The form of the hut uins is one of the subjects that has been most discussed, and even Virchow has written two essays to discuss the period at which these Italic forms were used in Germany. ${ }^{2}$

This year in the excavations of Phæstos, Dr. Pernier found a model of this form (Fig. 69), in addition to several others which have come to light in Crete. 3 It was thought that this hut repre-

"Gardner, "The Greek House," Gournal of Hellenic Studies, vol. xxi. pp. 293, 1901 .

2 "Sitzber. d. k. Akad. der Wissenschaft zu Berlin," 1883.

3 It is a circular hut of terracotta, $73 \mathrm{~mm}$. high with conical roof and rectangular door. An identical hut with a small door was discorered by Dr. Pernier at Phæstos in 1902. 
sented the primitive house of the Italic peoples; later it was found that even in the Stone Age similar round huts existed in the lake dwellings, and then they were discovered further off, in Egypt and in Crete; and these are more ancient and therefore nearer their origin. Similar models in terracotta were found in the Forum Romanum at Rome. I The entrance in the cinerary urns from the Forum ${ }^{2}$ also is made with a rectangular valve of clay, and as in the models from Phæstos there are two holes in the door jambs into which the bolt was pushed to fasten it.

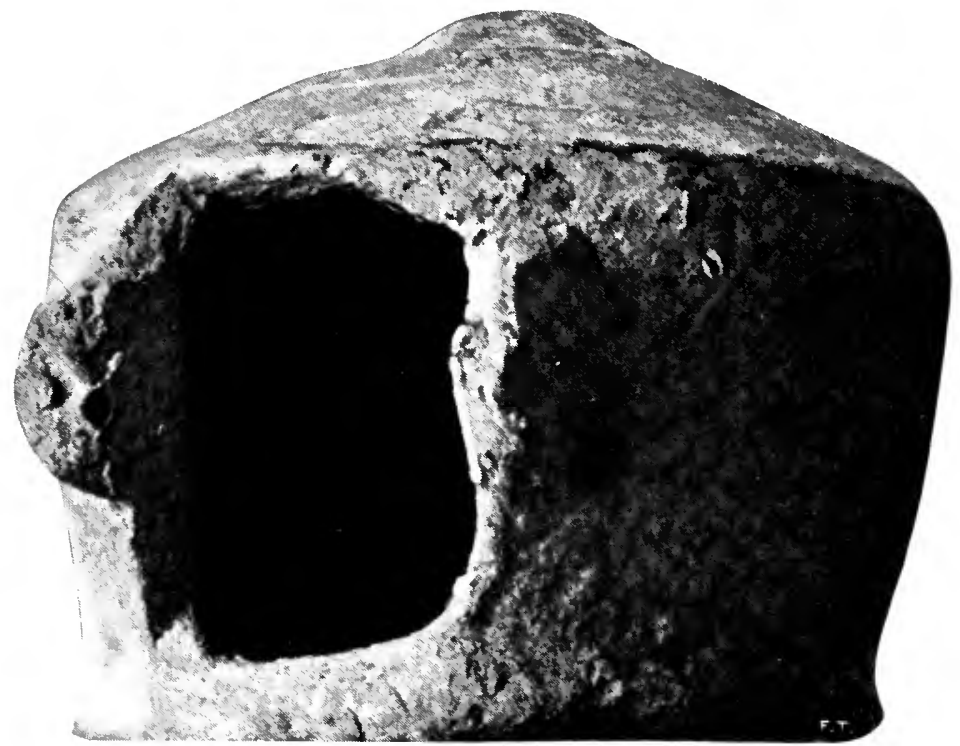

FIG. 69.-TERRACOTTA MODEL OF A HUT FOUND AT PHASTOS.

When the people who introduced cremation into Italy first arrived there, they did not use these hut-shaped ossuaries, at least so say Pigorini and Orsi. They accepted this form which already existed in Italy, and we now know that the most ancient examples of these huts were found in the islands of the Ægean, when cremation was not yet practised there. The Etruscans also made

I Pinza, Monumenti Antichi, xv. p. 470.

"Boni, "Foro Romano," Esplorazione del Sepolcreto, Notizie degli Scavi, iii. fasc. I. 
use of them and they are very common in Ltruria; these are, however, of less antiquity and generally belong to the early Iron Age. ${ }^{1}$

The study of the house is useful for the history of Mediterranean civilisation, for many have thought that the house was an invention of the Phonicians. 'This can be no longer said, neither did the Indo-Germans, who lived on carts, teach men to build. Even in the time of Tacitus bricks and mortar were unknown in Germany. In these days, when the struggle of class is becoming more and more keen, we may learn something by examining the earliest middle-class houses. They show how far democracy had advanced in the Mediterranean region, for the houses of the contemporaneous Egyptian bourgeoisie were made of simple clay from the river, or unbaked bricks mixed with chopped straw and dried in the sun.

The designs of these Mycenaan houses serve to give us an idea of the streets and squares in the time of Homer; the rhapsodists do not trouble themselves with such small matters. After this in the history of architecture we have to skip a thousand years before we come to the houses of Delos and those described still later by Vitruvius.

\section{V.}

At $\mathrm{K}$ nossos, where the excavations have been most extensive, many drinking-cups of terracotta have been found and left in heaps with other fragments of pottery, as it was useless to cumber the Museum at Candia with them. Every party which passes takes one or two as a souvenir, and there are enough to last many years. The labourers use them, and I too used one to drink out of ; they are four thousand years old, yet they are so red and well-rounded that they look as if they were only made yesterday.

At Phæstos a peasant brought us a bronze pot with three feet, one of the renowned lebetes often named in the Homeric

- A. Taramelli, "I cinerarii antichissimi in forma di capanna scoperti in Europa," Rendiconti R. Accad. Lincei, vol. ii. p. +22, I893. 
poems because they served as objects of exchange instead of money. Dr. Hazzidaki, who came to visit us, advised me to make a cutting and try to find out if there were some tombs at the spot where this lebes had been found. The place was promising; I made the first attempt upon a long terrace and cut into the slope, hoping to come upon the passage of some tomb. I spent some happy days sitting on the edge of the cutting while the labourers handed me the sherds of pottery,

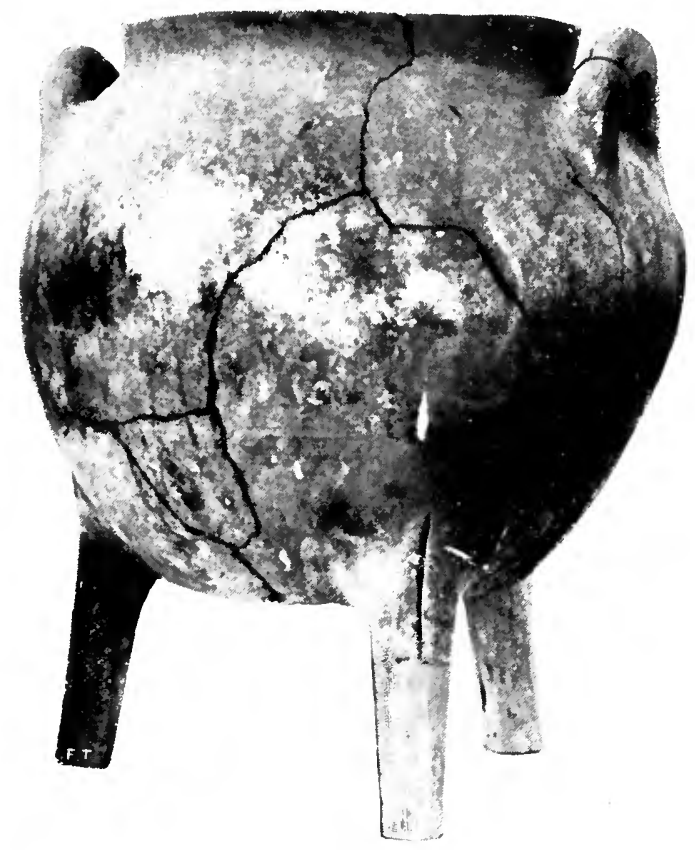

LIG. 7O.-TERRACOTTA COOKING POT HOLDING It ILITRES.

which they heaped up in baskets, but I only found coarse crockery, a number of cooking pots with three feet, and the bottom of a hut, with a great round hearth stone. Probably the labourers' dwellings had stood here. All the cooking pots, great and small, were broken, and it was impossible to put one of them together; but in other places some were found whole, like this of Zakros (Fig. 70), holding I4 litres, and completely blackened by long use on the fire. 
On my visit to a monastery near Voris I drank fresh water from a Mycenaan well; it had been cleared out a short time before, and near the wall of the well I saw the broken pieces of the amphora, painted in the style of the decadence of Mycenaan art, in which the water had been brought up more than three thousand years ago.

\section{'I.}

The spindle is the implement which has changed least in form ; as it was in Italy in the lake dwellings, as I found it in the excavations of the Neolithic age at Phæstos, it has come through the ages of bronze and iron to our own time, and the mode of spinning flax and wool has remained the same. The distaffs were of wood and are there no longer, but the reels of terracotta are well preserved, and also the stone discs of various shapes which were used strung on to the lower end of the spindle to hold it straight and keep it in motion.

There are numbers of bobbins for winding the thread. They are terracotta cylinders like the modern wooden ones, and have also a hole through the axis to enable them to be strung on the cross beam of the loom, from which the threads fall to form the warp. Not having the modern weaver's beam, smooth little weights of terracotta, stone, or marble, the size of an apple, were fastened to the threads to hold them taut; and these weights are found in great numbers in all the Mycenæan palaces. Some of these spheres have a groove across, round which the thread would be tied. It is suggested that they may have been weights for weighing with, but this explanation does not seem probable.

Small gold scales, like our own, were found at Mycenæ, and a weight, which probably served as a standard, has been illustrated by Dr. Evans; it is a piece of red marble of the colour of porphyry, in shape a quadrangular truncated pyramid, with a hole for suspension, and weighs 29 kilogrammes. The figure of an octopus embraces it on all sides with its tentacles. 


\section{$15+$ PALACES OF CRETE AND THEIR BUILDERS}

Other weights of hæmatite were found at Knossos of the same type as the weights used at the same period in Egypt; one weighs $2 \frac{1}{2}$ grammes.

I amused myself with the study of the domestic utensils in order to bring myself more into contact with the private life of the people of the Mycenæan age. The bronze sickles are not

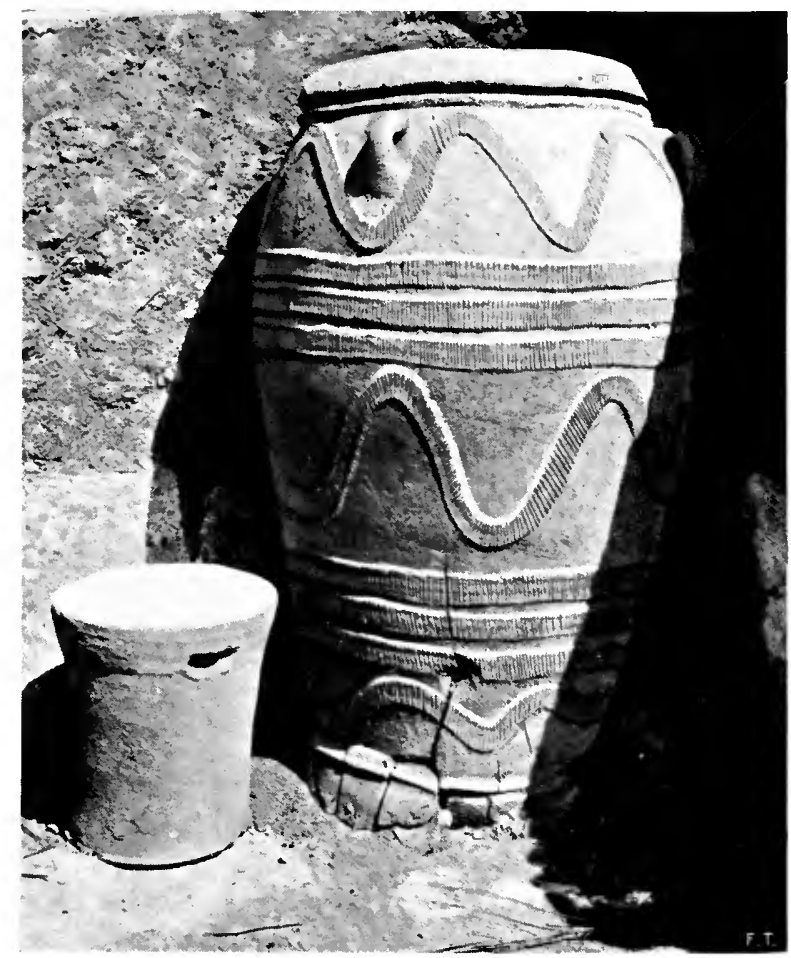

FIG. 7I. - TERRACOTTA BEEHIVE (UPSIDE DOWN) ANI) LARGE JAR FOUND AT PHASTOS.

curved like the modern ones, but are bent at an angle and have a longer handle, so that the peasants would bend down less than ours of the present day to cut the hay and corn.

Fig. $7 \mathrm{I}$ represents a terracotta beehive upside down and a pithos; these great jars of terracotta and the beehives are made to this day in the same shape. More than four thousand years have passed and have been as a moment; in the peasants' 
gardens beehives and jars are still the same as those made at the time of Minos. In the terracotta vases were found peas and beans, all burnt.

The granaries of Terracina, with the great clay pots, show how provisions and corn were kept. The great vases which we see placed as ornaments on the walls of some villas at Rome are half the size of these jars. The pithoi were also used to hold oil, and at first they were used as wardrobes for linen and clothes. The handles placed on the mouth to shut them with, and lower

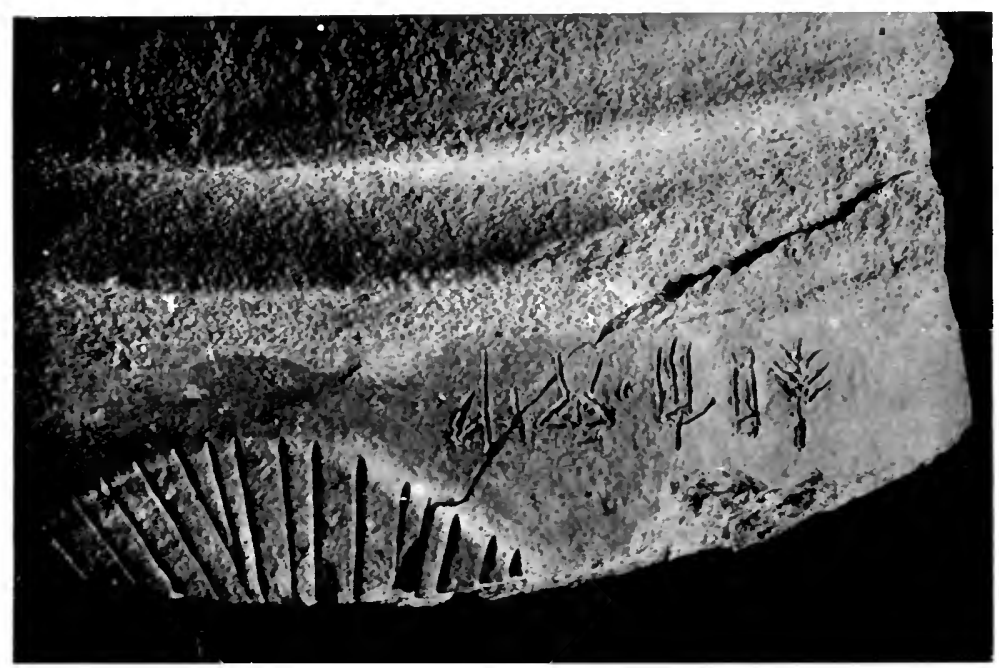

FIG. 72.-PIECE OF A TERRACOTTA VASE WITH INSCRIBED SIGNS FOLND AT PHASTOS.

down to lift them by, became an ornament, and when a certain style was given to them many handles were only used as a decoration.

Among the fragments of these vases there were some with marks of writing; I give an illustration of one of these pieces to prove that the workmen could read and write; as we have already seen, the pieces used for inlaying were marked with letters.

The furniture of the rooms must have differed little from 
that used at the present day, if we may judge by the inlaid work from the stone seats found at Knossos, from the terracotta lamp, from the recesses for cupboards in the chambers. Achilles said that a man could not easily lift the bolts of his doors I ; these must have been thick metal bars which ran through rings and were pulled by a handle! The room where the arms of Odysseus were, was closed by a latch. In all the Homeric poems there is no mention of a lock or a key. In Crete they were much more advanced, for in the Bronze Age there were keys with wards like ours. Fig. 73 is a charming key such as would be ma.te now for an elegant little box.

\section{VII.}

The excavations in Crete have put an end to the legend that the origins of civilisation were to be sought in Egypt, and that the peoples of Europe were in a savage state when there was a high degree of culture on the banks of the Nile. Dr. Flinders Petrie 2 has widely studied the relations of Egypt with the Island of Crete, and shows that this connection goes back to the earliest dynasties of the Pharaohs. Another class of foreign pottery was, he says, found in the ruins of the temple of Abydos which is of the time of the Ist Dynasty, or possibly earlier. It is of a material which has no counterpart in Egypt, a black, shining pottery; the shape, too, is not Egyptian. It is an amphora ending in a point with the neck curved, doubtless of Greek origin. Pottery exactly similar in material and make was found in Crete of the latest Neolithic period. A piece of this pottery from Egypt and a piece from Knossos when compared seemed to belong to the same amphora.

The impulse to civilisation did not, then, come from Egypt to Europe, but a common basis of civilisation existed on the shores of the Mediterranean before the dynasties of the Pharaohs arose; upon this stratum of Neolithic culture Egyptian and

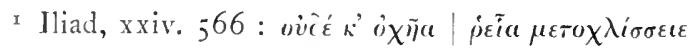

2 Flinders Petrie, "Methods and Aims in Archxology," 1904, p. 166. 
European civilisations were simultaneously devoloped, but in a mode different from each other. The Egyptians preserved the tradition of the continuity of history. In the Island of Crete we must search for the documents by excavation, for the recollection of past ages has been interrupted.

For this reason it would be well for some one to set to work on a comparative history of Minoan and Egyptian architecture. Fig. 5 I represents the northern entrance of the palace of Knossos. There are blocks of limestone $3 \mathrm{~m}$. long, 0.75 high, and 0.55 thick, very exactly cut. Of these masses seven rows are still quite in place with the corners perfect. The method of moving

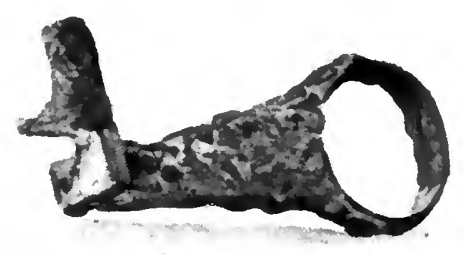

FIG. 73.-BRONZE KEY OF THE MYCENAAN PERIO1).

these great blocks must have been much the same as that described in the architecture of Vitruvius, and we can imagine the rollers, the inclined planes, the pulleys and the cranes, as they were used by Greeks and Romans. All the wooden objects have disappeared, and only on the tablets do we see traced the yokes of the oxen and the carts used for carrying these blocks.

The method of building used for the walls is so perfect that in some parts the plaster is laid on in three layers, the first coarser and the two others gradually finer and thinner. Thus we find this process, which is so admirable in Roman building, already in use three thousand years earlier. In the Museum of 
Candia we can also study the method of laying on stucco, for the great marble polishers with which the walls were worked after the layer of plaster had been laid on are still in existence. They are great parallelopipeds made of a long, narrow slab of marble, with a handle in the middle to enable them to be strongly gripped, and are smooth on the under surface. In short, the workers of the Bronze Age did their work in a way differing little from our own methods. At Candia, in the braziers' workshops, I saw that a tool is used exactly like the bronze one found at Hagia Triada (Fig. 74). The only difference is that it is now made of iron, but the shape is the same. At one end it is flat, at the other rounded, and it was used as a rest while hammering the brass. There was a whole series of little anvils like this for working brass and metal with the hammer. The cups of Vaphio, of which I shall speak later, are inimitable examples of the hammered work, called by the French repoussé.

The greatest difficulties are met with in engraving the hard stones-jasper, agate, cornelian, onyx, and garnet; but the beauty of the intaglios shows that patience overcomes all obstacles; with fine sand and perhaps emery, and with the help of the lathe and a bronze drill, the Cretans engraved in hard stones figures of men and animals with marvellous exactness even in the most minute particulars. Perrot and Chipiez collected on one plate the photographs of several Mycenæan intaglios which had been used as seals, and indicating the figures of bulls in the hard stones, say that nothing more perfect could be done. I

In the corner of a shelf in the Museum at Candia I saw the broken foot of a drinking glass found at Knossos. ${ }^{2}$ It is so like our modern glasses that many would suppose it to be a broken glass left by mistake in the case. Instead of this it is one of the rarest objects which displays the skill of the craftsman of the Bronze Age. It was a thick and very transparent rock crystal, and some one has defied the adamantine hardness of quartz and

I Perrot et Chipiez, "La Grèce Primitive" ("L'art Mycenéen," vi. Pl. xvi. p. 85 ).

2 Another was found at Palaikastro. 
made a drinking glass of it. Modern machinery and the hard temper of steel would enable us more easily to effect such a piece of work, but no one attempts it as we now have glass and any one can drink out of a transparent vessel at the cost of a few pence.

The thought of the years of work and the large sum of money' invested in a fragile drinking cup made me stop to consider whether there is any other object in which the power of labour has been more intensely absorbed and crystallised than in cutting this rock, paring thin the sides without breaking through them,

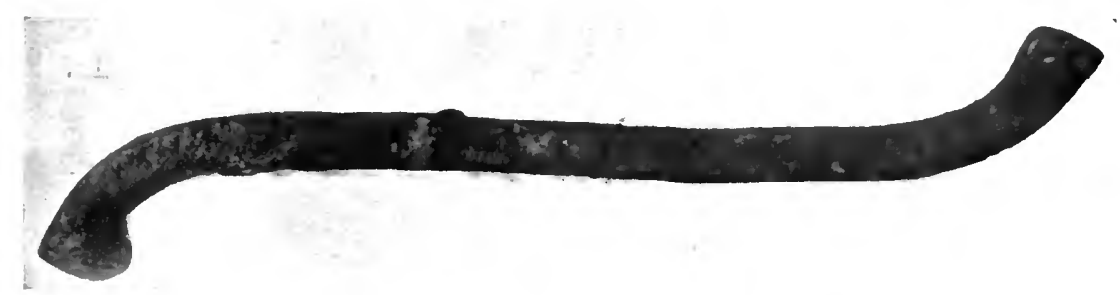

FIG. 74-BRONE CTEXSI, OF THE MYCENAAN PERIOD, STILL CSED BY THE IBR.AZIERS OF CRETE.

and giving it the form of a goblet with a geometric design at the base, and the polish of glass.

\section{VIII.}

The causes of the Cretan Hegeniony were two: peace and work. Minoan civilisation was more useful and fruitful to humanity than the Egyptian, with which it had arisen contemporaneously, because in Crete uninterrupted peace was of longer duration. The fact that the Cretan cities were built without towers and bastions and without any use being made of strong sites as a means of defence, and that the palaces were thus constructed as at Phrstos in the places least adapted for defence, proves that the islands, unlike the cities of mediaval Italy did not wage war on each other. On the other hand, warlike 
ideals and the art of protecting a city were highly developed on the mainland as in the case of Tiryns and Mycenæ.

Crete differed from ligypt in having suffered no foreign invasion; she was so powerful on the sea that, like modern England, she did without fortifications. It was enough to have harbours on the shores of the Mediterranean where there were forests to supply wood for repairing the masts and boats, springs to supply water, towns for the sale of merchandise and exchange of goods.

The other reason of the Hegemony was the freedom of the craftsmen. The culture of Egypt might be defined by the word crystallisation. King, priests, craftsmen, each in his own sphere of action, had organised a form of tyranny which impeded all progress. 


\section{CHAPTER VIII}

PREHISTORIC SOC1ALISM

I.

I R. STILMAN, American Consul in Crete, announced W in 1866 that he had found the great building for public assemblies, the so-called Sissitia (-vvoriala), where the earliest Socialists ate in common. Mr. Arthur Evans came and pointed out that beneath those ruins was the palace of Knossos. The soup kitchens, free meals for school children, and municipal bakehouses of the present day are trifles, for at that time men, women and children were all fed at the expense of the State.

Aristotle I says that in order to make rich and poor live under the same conditions they were obliged to eat together, and the cost of the food was paid by the State. Lycurgus had stayed long in Crete, where he found a people of the same race who ruled themselves according to the constitution given to them by Minos. In the beginning Crete had a monarchy; later on the government passed into the hands of ten Cosmi, who commanded the army and were at the orders of the Senate; but the Cretan institutions, according to Aristotle's account, came nearer to Communism than was the case at Sparta, where the public dinners in common were less well organised.

Nevertheless the defects of democracy were not overcome, as the following passage proves: "The Cosmi are often deposed by their own colleagues or by private citizens, who rise against r "Politica," bk. ii. ch. ii. s 10. 
them. But the thing most hurtful to the State is the total suspension of the Magistracy when powerful citizens who have joined together against them overthrow the Cosmi to avoid the judgment by which they are threatened. These disturbances are the cause of Crete having in truth no actual government, but only the shadow of one." I

In the Life of Lycurgus Plutarch describes the public dinners in Sparta. "Each man brought every month one medimnus of flour, ${ }^{2}$ eight jugs of wine, five pounds of cheese, two and a half of figs, and I know not what small sum of money." One can understand that this common dinner with only bread, cheese, and figs soon came to an end. The Spartans applied with extreme rigour the rule of meals in common, "so much so that when King Agis returned from the war in which he had defeated the Athenians, and wished to sup alone with his wife, he sent for his portion and the polemarchs refused to send it."

Economics have always been of the greatest importance in the history of nations; and in spite of similar exaggerations the Socialistic idea spread rapidly through Greece and Italy. Aristotle said that meals in common were known in Italy before the time of Minos.3 This would indicate that Mediterranean civilisation and Italy's share in the social movement is much more ancient than is generally believed; and we know also that in the most remote age the Government granted to the poor "the common use of property." 4

II.

On one of the clay tablets in the Museum of Candia we see repeated many times the figure of a man and woman; when we are able to read it we shall certainly be better acquainted

"Aristotle, "Politica," bk. ii. ch. ii. 7.

2 The medimnus was equal to 52 litres.

3 Aristotle, "Politica," bk. iv. ch. ix. \$ I.

4 Ibid., bk. vii. ch. iii. \$ 5 . 
with the social condition of this people. ${ }^{1}$ Whether they were free men or slaves, we cannot imagine here a state of slavery like that in the East or in Egypt, for the dominion of the sea can only be acquired by individualism and liberty.

Besides, we know from Aristotle that the Cretans treated their slaves as equals, and only prevented them from carrying arms or going to the gymnasium. ${ }^{2}$ At Dadalos the chiton of slaves was put on the statues; and this proves that even in classical times workmen although slaves were held in esteem.

The very architecture of the palaces of Knossos and Phæstos may testify to the power of the democracy. The liberal supply of seats in the palaces of Phæstos and Knossos was an expense forced on the architect by the crowding of a large public in the hall and courts, and by the freedom with which the people could enter the palace of the prince. Under an autocratic Government that was not possible. We see this in Italy; as long as the republics and the democratic Governments continue in power we have seats round the palaces-in Florence at the Strozzi Palace, in Rome in the Farnese Palace, and in various buildings of Bramante's; after the sixteenth century we find no more seats forming part of the decoration of palaces.

III.

An important fact in the history of Crete is the contemporaneous destruction of the palaces of Phæstos and Knossos and of the villa of Hagia Triada. Such a coincidence is not chance, but the work of a great revolution which convulsed the island; and the destruction was probably the result of war and of the struggle in which Socialism triumphed. We shall see presently that we must reject the idea of foreign invasion. The same people rebuilt the destroyed buildings, the same

I G. Busolt has studied the conditions of the ancient Cretan State, but we cannot enter into details here ("Die Griechischen-Staats und Rechts altertümer," Handbuch der Klas. Altertums-Wissenschaft, von J. Müller).

2 "Politica," bk. ii. ch. ii. 
men began again with the same magnificence. The work of destruction is too vast and contemporaneous to allow of Crete having been divided into small States which fought against each other. Possibly there may have been a revolution like the French Revolution which overturned the Government, and a restoration followed a few years later.

The rebuilt palaces are less enormous, as we may see at Phæstos. The blocks of stone which form the base of the walls of the most ancient palace are 3 metres long, and to the east and south the ruins of the ancient palace were filled up and there appears to have been no idea of building another palace above them. We found the same reduction in the magazines at Knossos. But this reduction in scale can be especially appreciated in studying the remains of the Mycenæan villa of Hagia Triada; we learn thereby that the wealth of Crete was diminished, and that, possibly through intestine strife, the dominion of the sea was lost.

Minoan power had reached its highest point when the primitive palaces were burned; art still grew, but, as in Italy of the Renascence, political decadence had already begun. In I 500 B.C. the palaces of Knossos and Phæstos were definitely abandoned.

\section{IV.}

The first writers on Socialism were Socrates and Plato, and it could not be otherwise with the philanthropic trend of their philosophy. The fundamental concepts of Communism were defended by Plato with profound conviction, but his proposal to hold in common women, children, and goods was at once regarded as utopian. An extract from his dialogues is enough to convince us that his Socialism could have no good result. "Women must go naked and they will then clothe themselves again with virtue instead of garments, they must take part in war, and in every way serve in the keeping of the city and do no other thing." I

$$
\text { ¿ Plato, "Republic," bk. v. }
$$


"Some festivals nust be established at which we will unite betrothed couples and offer sacrifices with marriage hymns by our poets." "The children who shall be born daily shall be collected by magistrates, superintendents, and similar officials, who shall take them to the care of nurses dwelling in a retired part of the city, but the children of evil men shall be hidden in secret places." The condemnation of Socrates and the criticism of Aristophanes on the stage demolished the theory of Socialism, and Aristotle was one of its opponents and demonstrated that the family and the State could not be one and the same. He says: "If we force this unity beyond a certain limit, the State no longer exists; or if it does exist its condition is deplorable. It would be as if one tried to make a chord with a single note, or rhythm with one single measure." I

In Crete the revenue of the State was divided into three parts: one was set apart for the worship of the gods, another for public expenses, and the third for public meals. Polybius points out the difference between the Cretans and the Lacedæmonians, and says that the Cretans were more democratic and constantly in revolt. The development of civilisation in Crete followed all the same phases which we see in the history of modern Europe from absolute to parliamentary government, from democracy to Socialism. The Greeks took their democratic spirit from this island as well as their national divinities. In Homeric times republican life was already in full vigour. The warriors were assembled by Agamemnon to deliberate before the battle, and when Odysseus arrived at the palace of Alkinoos a herald summoned the princes and captains to the forum.

The history of Mycenæan civilisation is now becoming clear, and it has a great attraction for students, who may learn from it how the soul of our nation was formed, for the mysterious happenings which guide society and history on the shores of the Mediterranean will always depend on the same influences.

The psychology of the Minoar people is the most ancient expression which we now know of the soul of our fathers. r "Politica," bk, ii. ch. ii. 
Modern life is the fruit of germs fecundated on the shores of the Mediterranean, and urged irresistibly towards the north by the breath of civilisation. The long peace enjoyed by the Mycenæan people, their industry, their commerce, and their democratic government under the guidance of princes are facts important to social science. We here reach the earliest source of the Greek and Latin spirit, but Cretan Socialism was very different from that of to-day, in that the laws were chiefly devised with the object of preparing the nation for war. I In noting this point Aristotle adds: "Every nation in a position to satisfy its own ambition will appreciate warlike valour." 2

\section{V.}

In Sicily I have seen a party of peasants returning from the fields to the town with their sickles on their shoulders, singing the song of the labourer. This scene so closely resembles the figures in relief on a Cretan vase that I will speak of them in this chapter. It is a celebrated vase of steatite found by the Italian Mission at Hagia Triada. Unfortunately we only have the upper part, the legs of the figures in relief are wanting 3 (Fig. 75).

Savignoni, who illustrates this vase, thinks the men are soldiers. 4 Bosanquet 5 explains the figures of this relief as a joyous band of reapers. ${ }^{6}$ There are two companies-the first of four couples, the second of six. The fact that they are all

I On the tablets discovered by Dr. Evans at Knossos there is an entry of two stores of arrows, one of 6010 , the other 2630.

2 "Politica," bk. iv. ch. ii. 5.

3 The vase had been carved in three separate parts and then skilfully joined. We have two of these pieces-that forming the neck of the rase is shown (Fig. 75). They are pieces of steatite worked on the lathe. Fig. $76 a$ and $b$ show the design without the neck.

4 Monumenti Antichi, R. Accad. dei Lincei, xiii., 1903.

5 Fournal of Hellenic Studies, vol. xx. p. 389, 1902.

6 Milani thinks it is a religious procession, and various explanations have been given by others. Vide "Studii e materiali di archeologia," vol. iii. p. 84 . 
moving in step, lifting the left leg at the same moment, much higher than the march of a soldier would necessitate, shows that this is not an ordinary march; on the other hand, it is difficult to believe that they are dancing to the sound of their song and the sistrum because a slight turn of the body would cause an entanglement of the forks which these men carry on their shoulders. I give first the side of the vase, showing the captain, who wears a full cuirass of mail (Fig. 75), and next the side, showing a man bent down to the ground (Fig. 76a). That it is not simply a march is also proved by the position of the right arms, which are

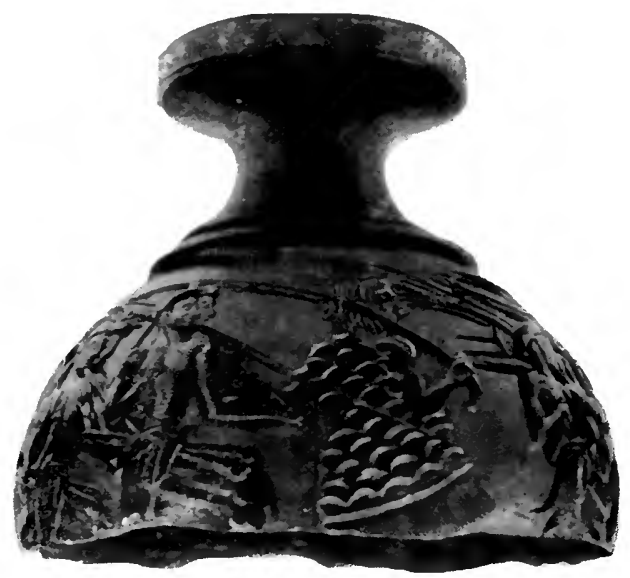

FIG. 75.-VASE FROM HAGLA TRIADA ILLCSTRATED BY SAVIGNONI.

all bent at an acute angle, with the hand clenched on the breast. On the left shoulder they carry a fork with three very long prongs, all exactly alike, a long shaft with three prongs and a small sickle. The fork is like those now used, but it is difficult to say what is the implement with it-whether it is an axe, a pickaxe, or a small scythe.

If they are soldiers it is difficult to understand why they have no shield or other usual arms, and not even a helmet. A sickle? The implement carried on their shoulder is too short to reap with. A weapon? The three prongs of the fork are too long and 
slender to be used as a spear. The trident, says Savignoni, was used as a weapon, and the retiarii were armed with it in the gladiatorial shows. Seafolk might have adopted an implement used in fishing, or the peasants might have taken to the trident, but only in an exceptional case. The fact that no such weapon of bronze has been found, and that these are evidently tied up with a cord, indicates that these forks are of wood; in this case the prongs are too long and slender to be used as weapons of offence. Another doubt arises when we study the figure which is supposed to represent the captain, for he wears a large corselet of mail. His head is bare and he holds in his hand a slender

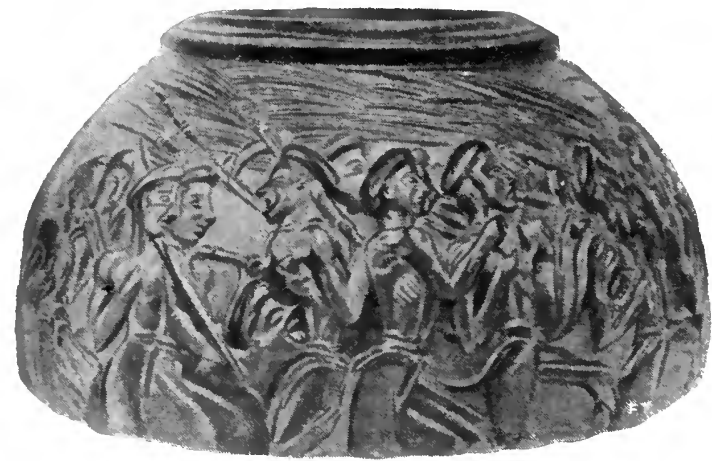

FIG. 76a.-VASE FROM HAGIA TIRIADA.

stick with curved handle, taller than a man. Also he is unarmed, and it would have been more likely for a warrior to cover his head with a helmet and to hold a sword or lance such as are often found in excavations. On the opposite side of the vase (Fig. $76 b$ ), a man is playing on the sistrum, an instrument of Egyptian origin, which was used at sacrifices and festivals. The usual type has four transverse bars (this has two) and is made as a closed diapason; it is sounded by shaking it. Savignoni thinks that the three persons standing behind with open mouths are three women wearing a leather garment which covers the breast as described by Herodotus, and that they are possibly slaves taken in war; he adds that they are of different race and probably from Libya. 
They seem to me too merry to be the booty of war, or women who have been enslaved. On the seal (Fig. $3 \mathrm{I} a$ ) is a cuirass made with the same curve, and I am not sure that these figures are not men.

An Egyptian artist would only have shown a row of persons turned sideways, all exactly alike; here, on the contrary, in every group we see different attitudes, and though the faces are all in profile, there is much more life than the sculptors on the banks of the Nile could bring into their work. There is so much feeling in this cortege, such naturalness that not until the fifth century B.c. should we find a sculptor capable

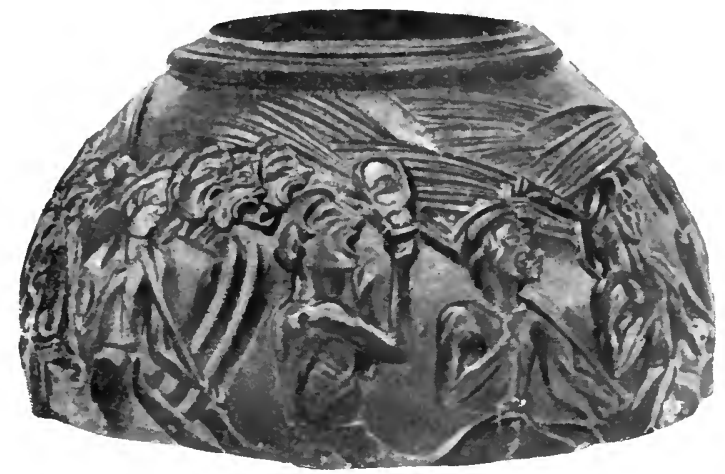

FIG. 766.-VASE FROM HAGIA TRLADA.

of representing with such absolute truth a party of men in motion.

\section{Y.}

I think they are reapers returning merrily from the country singing and dancing, but it is more prudent to suspend our judgment in the hope that further excavations may bring to light the missing piece of the vase.

A rebus composed of figures representing a phrase is easy in comparison with the riddles of archæology, and we have an example of this in Figs. 75, 76a and $b$. I will first quote Savignoni's explanation of this vase: "Between the fourth and fifth couples 
appears the half figure of a young man, his head only reaching to the waist of the nearest soldier, whose leg he holds with his right (and possibly also with his left) hand, while he turns up his face, with his mouth wide open, evidently shouting, to this same soldier. The position can only be that of a person who has fallen or is stooping, or in some way squatting down. At first I thought it was a soldier who had accidentally fallen during a forced march, and that he was holding on to one of his companions and asking help lest he should be trodden down by those who follow; but this hypothesis must be set aside. In fact, the attitude and expression are those of a person who is imploring desperately without producing any good effect on the soldier whom he is holding, nor on those who follow ; on the contrary, it seems that the soldier, while continuing his way without stopping, looks back and shouts at him, either cursing the poor wretch and ordering him to follow without being troublesome, or telling the two last couples to take no notice, or, if necessary, to push him forward. He seems to me to be a prisoner dragged away by soldiers in the same fashion as the prisoners shown in the Egyptian triumphal marches."

In my opinion, however, it is a joyous march resembling a dance, and Savignoni's own studies on the Mycenæan monuments have confirmed me in this idea.

He describes a gold ring found in the Necropolis of Phæstos, ${ }^{\mathrm{I}}$ on which a nude woman is performing an orgiastic dance. "It is a species of Russian dance," says Savignoni, "in which the dancer crouches and rises again." Then in a few lines he points out the monuments on which the dancing figures stoop to the earth. The most important example which is contemporaneous with this vase is the fragment of a pyxis found at Knossos by Dr. Evans, where a man, while dancing, stoops to the ground much in the same fashion as the figure under discussion.

This Mycenæan dance still survives in the popular dances of Crete, and I saw it in several places. Dancing to the sound of their own voices, from time to time one of the dancers

- Monumenti Antichi, R. Accademio dci Lincei, vol. xiv. p. 578, Fig. $5 \mathrm{r}$. 
stoops and strikes the ground or his foot with his hand. Such is the interpretation which I propose. Admitting that this people dance and sing (and on this point there is no doubt), we have in the attitude of the person who is stooping to the ground the characteristic of a Cretan dance; this would explain why he sings and no one takes any notice.

As for the women (said by Savignoni to come from Libya), I said that I was doubtful on this point. They may be three men, I convinced myself of this by a study of Savignoni's own works and the seals published ' by him. I reproduce one in Fig. 3 I $a$.

The question is important, for Savignoni claims to have found in this relief proof of the relations of Crete with the shores of the Libyan Sea in very remote times. The image of the lion, which is often found on seals, and the abundance of ivory in Crete both prove the existence of these relations. But these faces do not appear to me to be of exotic type. Savignoni says: "The conveniently short hair and face smooth shaven like that of the male dancer, might leave us in uncertainty as to their sex, were it not that on the neck of the figure nearest to the second in command we can see a smooth mass raised and ending in an oblique furrow, which can only be a part of the hair falling on the shoulders." 2

This argument does not convince me, for in nearly all the figures which I have reproduced we see that the men of Crete wore long hair.

It does not seem probable that a prince ordered this vase to record some feat of arms. The artists were too skilful for this to have been the case here. They were able to represent correctly whatever they wished, and this scene could only show an insignificant military action, at the most it could only indicate a rising or an episode of civil war. Such a scene was little adapted for the decoration of a vase which probably served for holding perfumes. I therefore consider the subject to be a rustic idyl of peasants returning from the country, singing, and, perhaps, dancing a Cretan dance. Whatever may be the interpretation of the scene, from the point of view of anatomy it is certainly one

$$
\text { I Op cit., xir. p. 30, Fig. 20, p. +2, Fig. } 35 . \quad 2 \text { Op cit., p. I } 21 .
$$


of the finest of Mycenæan works. In the shoulders and thorax the muscles and skeleton are perfect. To indicate only one point - look at the knee; the tendons and patella are executed in every figure with scrupulous accuracy. The vivacity of the attitudes, the care shown to avoid monotony in the similar figures which form the cortege, the realism of the composition and modelling surpass all that we can imagine.

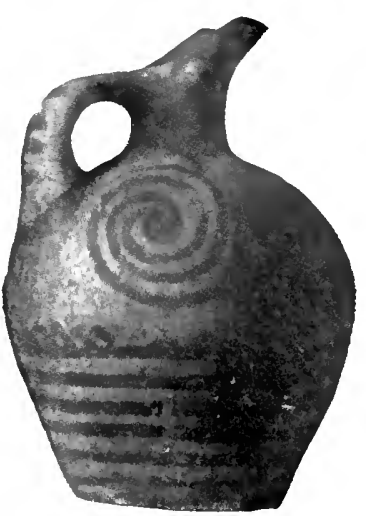

FIG. 77.-PAINTED JUG IN LATE PRE-MYCENEAN STYLE FOUND AT PHÆSTOS. 


\section{CHAP'TER IX}

MYCENA:

I.

\E must not think that a traveller with his "Bædeker" is an object peculiar to modern life; the ancients, too, had their guide books for travelling. One was written by Pausanias for Greece in the reign of Marcus Aurelius. I read there that in the district between Corinth and Mycenæ I more than half the population were occupied in fishing for the shells from which the purple dye was made; at that time, as now, there were pine trees on the strip of land which joins Greece to the Peloponnesus; and we are told how the Priestess Pythia dissuaded Knidias from cutting through the isthmus. Mycenæ stands in one corner of the road which connects the Eastern with the Western Sea; and the princes of Mycenæ took toll of men and goods which passed that way. Now the railway winds round the cart road from Argos, and after passing through a defile famous for battles in the War of Independence in I822, Mycenæ appears between two hills. The ruins are difficult to see because they are of the same colour as the rock. Half an hour from the station is a small Albanian village, and I stopped to look at the strange costumes of these people who speak no Greek. There are nuclei of population scattered over Hellas, representatives of the latest wave of prehistoric currents from the shores of the Adriatic. 
Not far from this village of Charvati is the tomb of Agamemnon, known by the name of the Treasure House of Atreus, and next comes that of Clytemnestra, excavated by Mrs. Schliemann (Fig. 78).

We know that the tomb of Isopata, discovered by Dr. Evans at Knossos and exactly similar to this, dates back to two thousand years before the Christian Era. There also is a corridor of about 20 metres in length called the dromos: next comes a vestibule and then the sepulchral chamber. Similar tombs are found in Italy, and there is one at New Grange in Ireland. I The study of Mycenæ has increased in interest since the excavations in Crete, for we can now fix more correctly the chronology of the Greek monuments and see how the Minoan culture spread towards the continent. In Southern Europe in the tombs of the Giants, as they were called, only stone implements were found, while in Greece and Italy these tombs belong to the age of bronze.

The slow movement of civilisation causes these delays and complications. The same thing is now happening in Africa, where some peoples use the bow and arrows contemporaneously with the breech-loading gun. The cult of the dead gave an impulse to the construction of immense edifices copied from those of southern countries when the age of stone had not yet been left behind. We have here another indication that European culture originated in Greece and in the Isles of the Ægean.

II.

The Homeric poets knew Mycenæ and "proud Tiryns of the high walls," and said that Mycenx, "well built and rich in gold," is behind the corner of Argos. Euripides and Sophokles placed here the scene of their tragedies.

As a rule famous monuments of which one often sees pictures do not impress us much when we visit them, but the entrance of the gate of Mycenæ (Fig. 79) aroused great emotion in me. The walls here form a more wonderful whole than all the z Transactions of the Rayal Irish. Academy, xxx. (J. Müller, 75). 


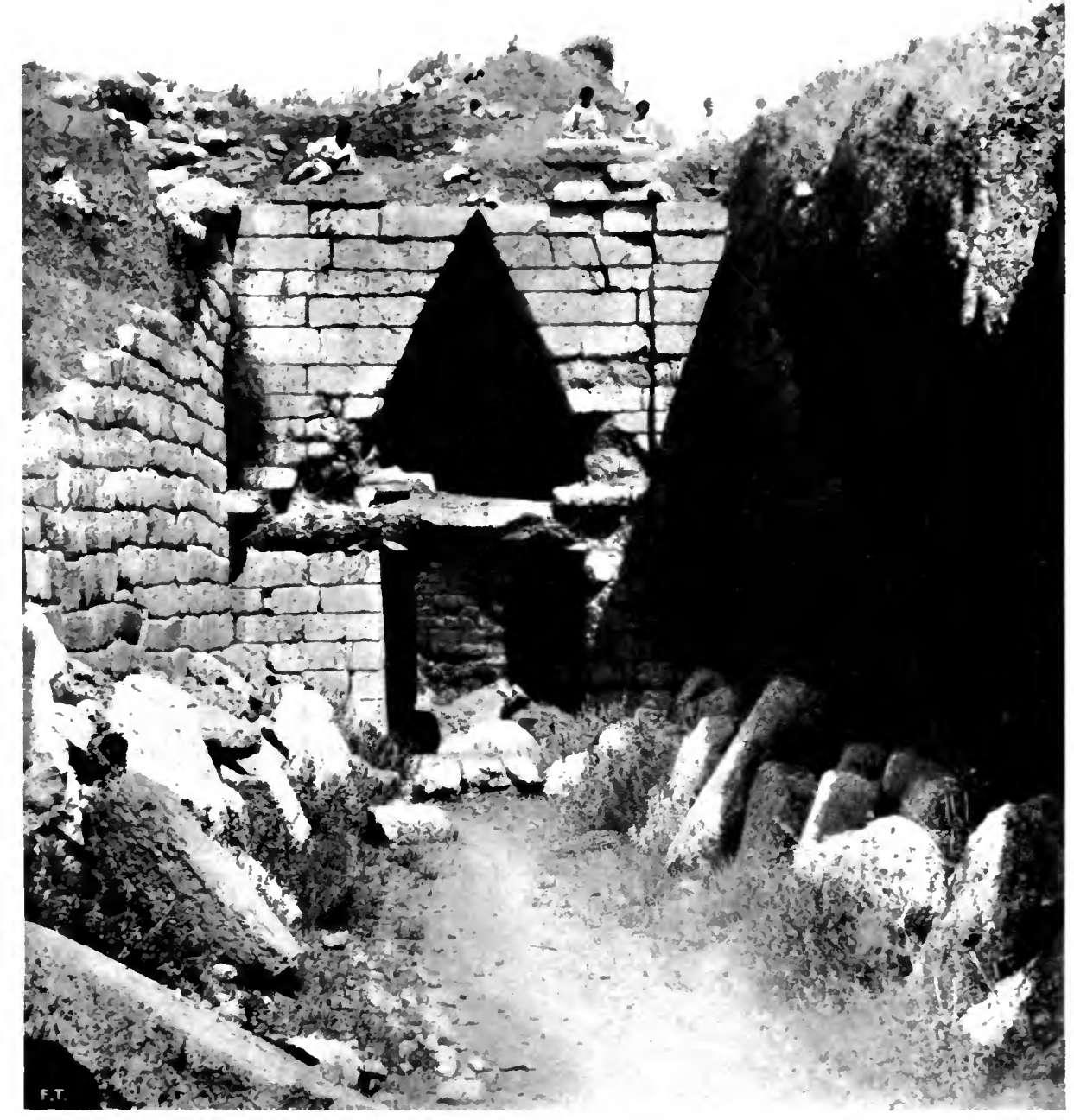

FIG. 78.-TOMI OF CLITEMNESTRA AT MYCEN.E. 

Pelasgic constructions which I had seen elsewhere. In the great superimposed blocks three loopholes overlook the entrance. A single stone 5 metres in length and 2 in breadth forms the architrave to the gateway, and two other stones, slightly

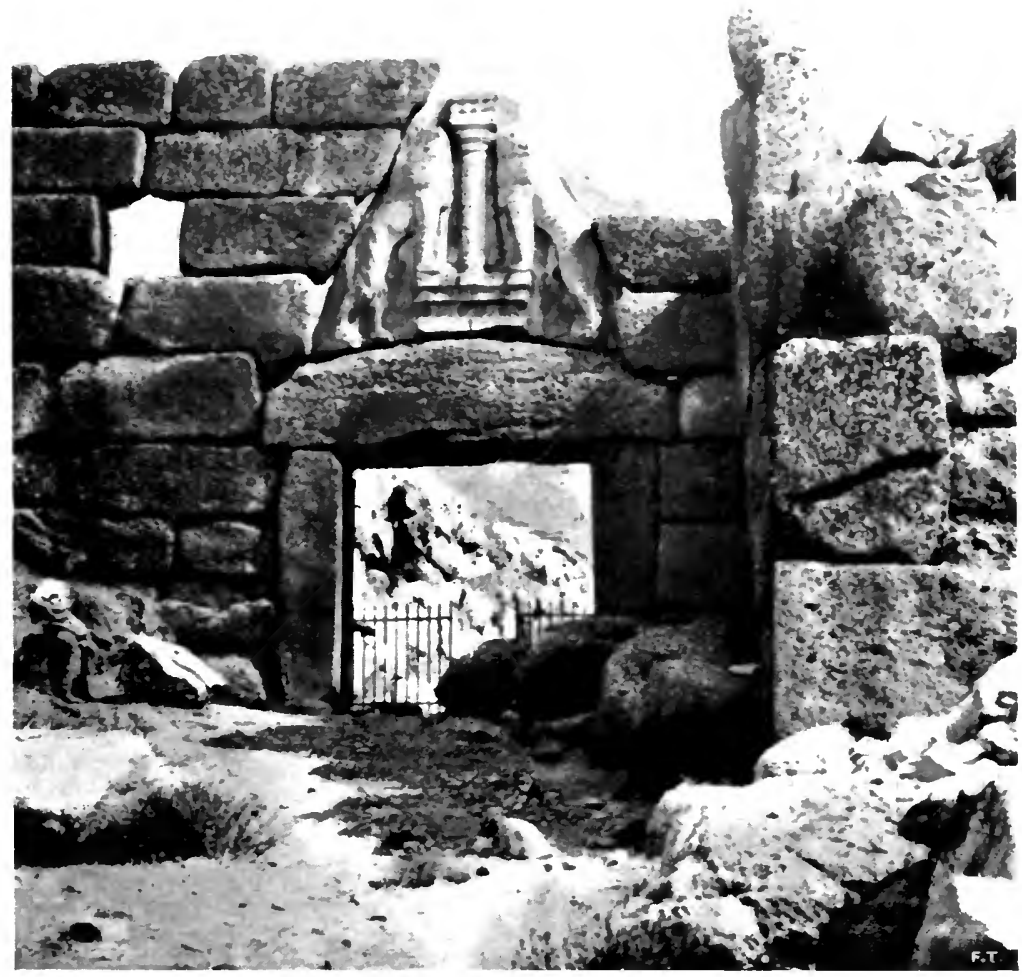

FIG. 79.-THE LION GATE OF MYCENA.

sloping inward, form the jambs. Above stands the great triangular relief of the lions. To reach the gate the road which passes along the walls turns at a right angle, thus rendering it an easy matter to defend the entrance by the discharge of arrows and stones from the loopholes. The Cretans 
have built nothing equal to this, for as rulers of the sea they were safe from invasion. Pausanias speaks of the lions which stand above the gate and says that the walls, like those of Tiryns, were the work of the Cyclops. This relief is certainly the most ancient piece of sculpture now known in Greece.

This gateway was at one time considered to be Oriental in style, and these lions were quoted as a proof of the Eastern origin of the primitive Greeks. Now we know that it is a decoration of Cretan character, and we shall find examples of similar pillars in the following chapters. The Etruscans had placed a similiar piece of sculpture above a gate of the city of Bologna, ${ }^{1}$ but with two calves instead of two lions.

As I enter I stop to look at the insetting of the huge lock in the gate posts, the square holes for the bars, and below in the corner other round holes for the pivot hinges. It is difficult to convince oneself that these walls are of less antiquity than the rectangular-faced blocks with the well-chiselled surface which we see in the palaces of Knossos and Phæstos, but there is no doubt that the walls of Mycenæare more recent. They were built in this manner, not because the tradition of a more finished style of architecture was lost, but in order to give this characteristic style to a fortified city. On the western side a part of these same walls is built of well cut stone in smaller blocks.

\section{III.}

Pausanias speaks of the Treasure House of Atreus, of his tomb and of the number of persons killed with him on his return from Troy by Ægistheus. When Schliemann discovered the tombs of Mycenæ in 1876, he thought he had found the tomb of Agamemnon and the five graves recorded by Pausanias, and stopped there. The Archæological Society of Athens commissioned Tsountas to complete the excavation of Mycenæ, and other tombs were discovered. Schliemann's

I Brizio, "Guida del club Alpino bolognese," Pl. VII. p. 2 10, I88 I. 
account of his successive discoveries is, as I)iehl says, like a romance. ${ }^{\mathrm{T}}$

Euripides, in the Orestes, speaks of a circular Agora which lies behind the gate of Mycenx, where Schliemann made his excavations. In the Acropolis, before reaching the tombs, Schliemann found the sepulchral stelai with reliefs less fine than the lions of the gate, but we must not consider these stelai to be more ancient than the lions, rather the reverse; other stelai have been found in Sicily with similar spiral decoration, and professor Orsi has collected them in the Museum at Syracuse. The lion relief, the stelai and the walls of Mycenæ have been preserved because these ruins are alone. Possibly the burning of the forests may have rendered the country barren,

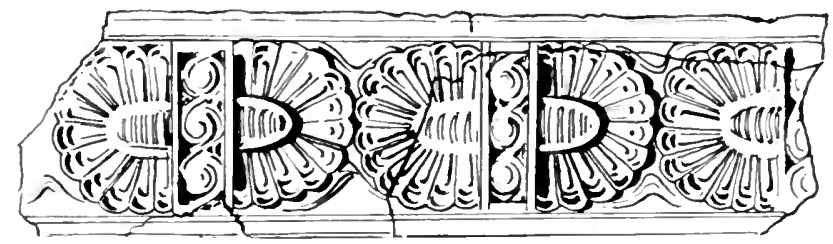

FIG. SO.-FRIEZE CARVEH IN RED LIMESTONE. KXOSSOS,

and Mycenæ was saved because no city rose near this site, and stone being plentiful no one needed to seek the blocks from her ruins to use for building.

\section{IV.}

Sculptured friezes, like those at Knossos, have been found at Mycenæ and Tiryns. Instead of showing here the fragment discovered by Schliemann, now in the Museum at Athens, 1 give a similar piece from Knossos (Fig. 80) to show the influence of Cretan culture upon that of Mycenæ. It is a design of rosettes separated by triglyphs with three small spirals. Circular rosettes, entire or divided in the centre, or oval rosettes form

I C. Diehl, "Excursions Archéologiques en Grèce," p. 2\%. 
one of the commonest motives of the frescoes and decorative sculpture of the Mycenæan palaces. The small leaves like those of marguerites are double and triple and are worked with much care both in the hollowed and the raised parts. The stone is a red limestone resembling porphyry, and as this marble is not found in Greece it is probable that these reliefs were imported from Crete; they are certainly the work of the same artificers. According to Dr. Evans's classification the third Minoan period

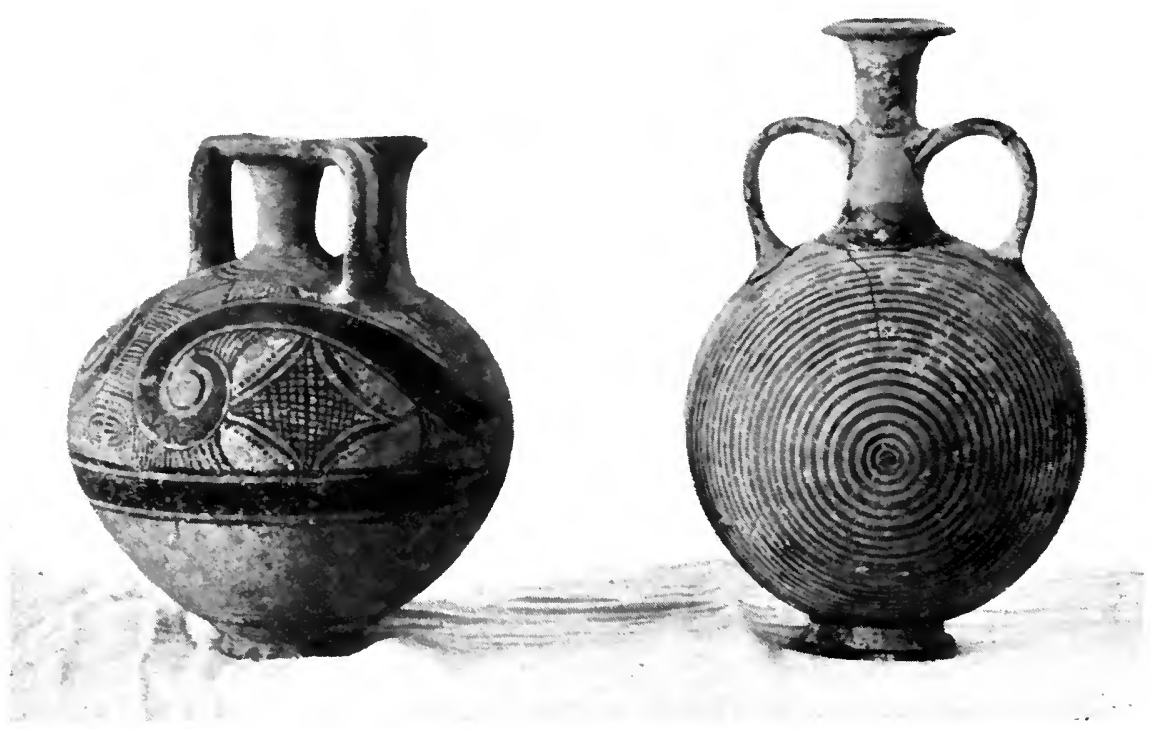

FIG. Bi $a, b$. CRETAN VASES IN MYCENAAN STYLE.

in the history of Crete is contemporaneous with the tombs found in the Acropolis of Mycenæ. During this period the vases with a brown ground gradually disappear, and we find pottery with a yellow or whitish ground and dark decoration and a new shade of red with good glaze which are the special characteristics of the Mycenæan vases.

Some of these vases, dating from about I 500 B.c., are illustrated in Fig. 8I. The vase on the left is 15 centimetres high, has a false neck, and is of yellowish earthenware with 
brown decoration. The design shows a stylised polypus with geometrical ornament. The next vase, $b$, is a bottle of Cypriot type with globular body and small circular base, of yellowish earthenware with red glaze and is decorated with concentric circles. In the great vase (Fig. 82) we see a change

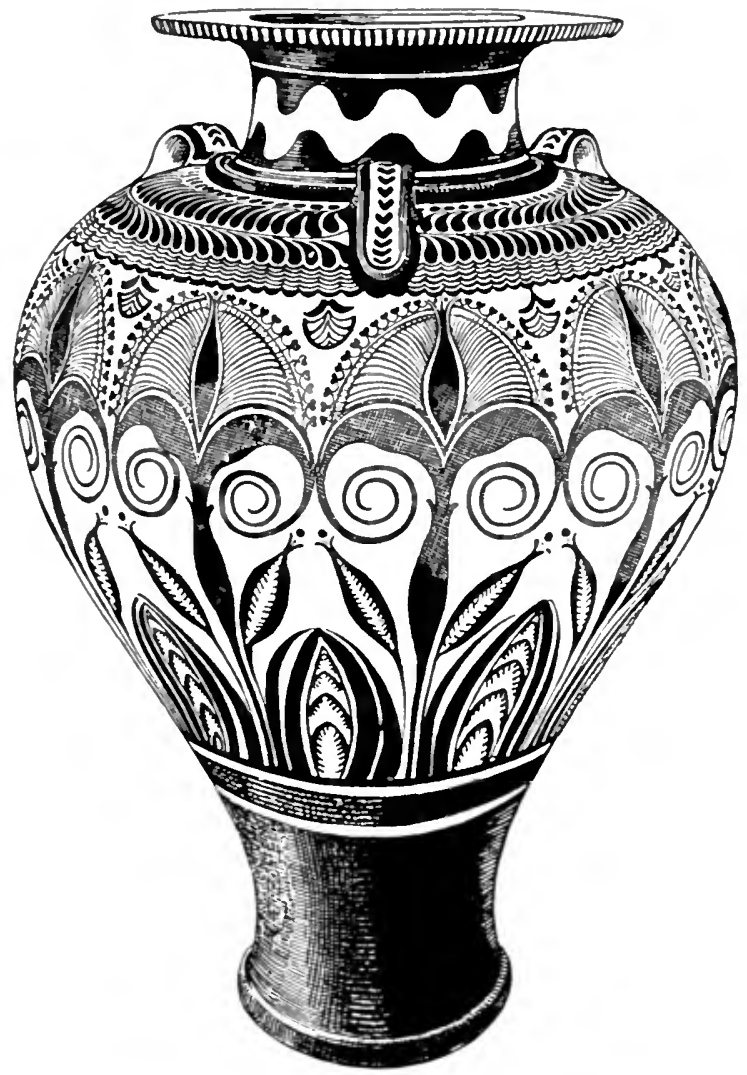

FIG. 82.-TASE IN WYCENAAN STYLE FOUND IN THE TOMB OF ISOPATA AT K.IOSSOS.

in the style of ornamentation. Just below the neck are three handles and a double row of leaves. The artist leaves nature further behind and depicts conventional forms of plant life in almost architectural style with a tendency to spiral patterns. This great amphora, 63 centimetres high, was found by 
Dr. Evans in the tomb of Isopata. I A similar transformation in decorative art is shown by the frescoes of the palace of Knossos.

Even a superficial observer can distinguish in the excavations of Mycenæ two categories of objects belonging to two different strata of civilisation.

It is doubtful whether the pottery known as Mycenæan was of local fabrication or was imported from Crete. A vase with lilies (Fig. 83) found in the villa of Hagia Triada has the characteristics of the Mycenæan vases, and marks the earliest period at which designs began to be drawn in white on vases of lighter ground than the earlier types. At this epoch appears the decoration of spirals and horizontal lines which become later one of the characteristic motives of the Mycenæan style. Dr. Mackenzie remarks that the designs representing birds, fish, and animals, which are so common in Mycenæan vases, are first found in the period of decadence in the palace of Knossos.

As we know that nowhere in the Mediterranean did pottery make so much progress as in Crete, and also that after the Kamares period there were always skilful craftsmen in this island, and that their technique reached the highest degree of perfection, it is natural to consider Crete as the island which gave the impulse to the creation of the Mycenæan type of pottery. At Knossos we find the earliest traces of the Mycenæan style with the type from which it is derived, and also the whole series with each gradation which marked the evolution of Mycenæan ceramics.

Dr. Mackenzie ${ }^{2}$ gives another proof of the Cretan origin of these vases by showing that fictile decoration of the Mycenæan style manifests itself contemporaneously with the

I Evans, "The Prehistoric Tombs of Knossos," Archcoology, vol. lix., 1906.

2 Duncan Mackenzie, "The Pottery of Knossos," Fournal of Hellenic Studies, vol, xxiii. p. 200, 1903. 
same type in the paintings and frescoes of the palace of Knossos.

After the Mycenaan civilisation came a long period of darkness, before Greece again became conscious of her own greatness. We do not know how Mycenaan civilisation was exhausted. According to Herodotus the population of Crete was three times destroyed by pestilence. These terrible epidemics were frequent. The Iliad begins with the descrip-

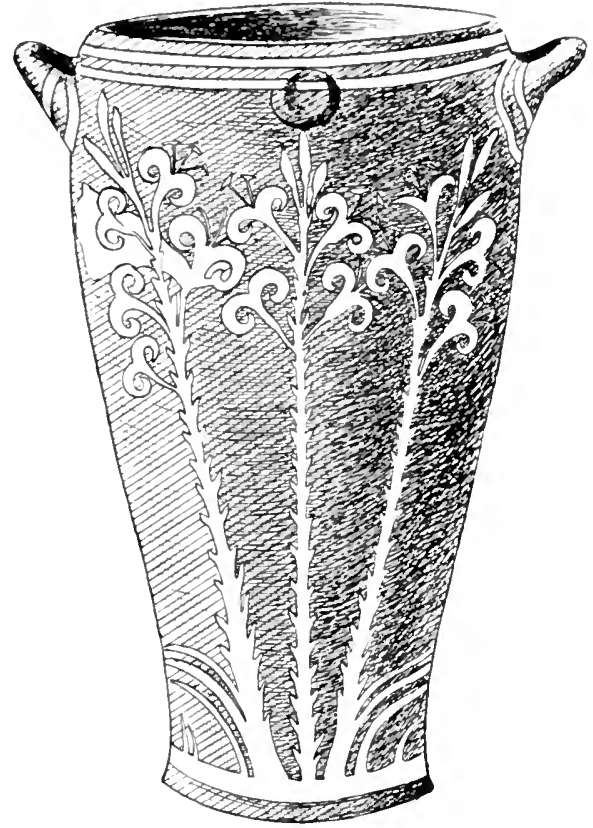

FIG. 83. - VASE IN PRE-MYCENAEAN STYLE FOTND

IN THE VILLA CF HAGIA TRTAIA.

tion of the plague in the camp of the Greeks; it is quite a different epidemic from any present one, and resembles that of Athens described by Thucydides. We are as yet ignorant of the nature of this disease, which is termed by the most competent physicians Typhus antiquorum. I In these days there is no epidemic which destroys men, birds, and beasts at the same time.

r Haeser, "Geschichte der Medizin," vol. iii. 
The Pelasgians came from Crete to occupy the Gulf of Nauplia. They founded Tiryns, Argos, and Mycenæ, and fortified themselves on these sites to dominate the road which connected the two seas. In "Iphigenia in Aulis" Euripides wrote :-

$$
\begin{aligned}
& \text { "O my Country, O Pelasgia, } \\
& \text { O my home Mycenæ." }
\end{aligned}
$$

The origin of the Achæans and their expansion in the Egean are two most important problems, around which the forces of the archæologists are concentrated. Professor Dorpfeld, the collaborator of Schliemann (and certainly one of the most competent inquirers in the field of Mycenæan antiquities), maintains in one of his recent writings I that the Achæans had some influence on Cretan civilisation. His opponents, and amongst them Dr. Mackenzie, assert that if the Achæans reached Crete they arrived too late to be considered as a factor in Cretan civilisation. The excavations show that the first people who invaded the Island of Crete were of the same Mycenæan race, a people of the same stock as the Cretans and not of Achæan origin. These were the invaders who destroyed the palaces of Phæstos and Knossos; the Achæans, if they came at all, arrived too late to exercise any reconstructive influence and could do nothing beyond hastening on the dissolution.

Thus says Mackenzie,2 and adds that when at length the first wave of a people of Achæan race proceeding from the Hellenic trunk appeared on the scene of Cretan history, the palaces of Knossos and Phæstos had long been a venerable ruin.

Diodorus tells how Mycenæ came to be destroyed. When the Argives decreed that they would not send help to the

" Athenische Mittheilungen," xxx.pp. 25T-297.

2D. Mackenzie, "The Cretan Palaces and the Agean Civilisation," Annual of the British Sctool of Athens, xi. pp. 18 $1-223$, 1904 . 
Lacedamonians who were encamped at Thermopyla, unless they were allowed a share in the command, the citizens of Mycenx alone of all the inhabitants of Argolis sent reinforcements, and eighty soldiers of Mycena fought at Thermopyla. The Argives, jealous of the ancient glory of Mycenx, destroyed it and thus ended the most ancient city of Greece ${ }^{I}$ after a long siege in +68 B.C.

\section{VII.}

I decided to ascend Monte Zara, which overlooks the ruins, in order to see the plan of the city more clearly and to study the method in which the position had been fortified. Mycenæ stands between two deserted peaks, ${ }^{2}$ and from above it was easy to follow the lines of the bastions, which in some parts are 5 metres thick. A small gate on the northern side served for sorties to harass the besiegers. Half way up, about a kilometre from the city, another wall formed a first line of defence, and a little below it I could see the head of a Mycenaan bridge, the most ancient bridge that I know.

When Pausanias arrived, the river Inakhos was dry. Possibly the deforestation of Arcadia had already begun. The boars' tusks and the stags' horns which were found in the tombs are the last vestige of the vanished woods. "This parched land has indeed the feverish look of a thirsty man." 3

On the top a growth of thorny brushwood covers the poor soil, and the colour of the dry dust shows through the leaves. Only the shrubs whose roots are deep in the ground can resist the parching heat, the others are dried up and stunted. The asphodels and some other plants of the lily tribe, whose bulb root affords them nourishment, show a clump of green leaves, all else is parched and stunted. Down in the valley planes and oleanders follow the curves of the Inakhos on the red soil of the banks. In the barren fields among the olives lies a long stretch

"G. Busolt, "Griechische Geschichte," 2e, Aufl. (Gotha, Igo3, p. 6).

"Monte Elia, $70 \mathrm{~m}$. high, and Monte Zara. $600 \mathrm{~m}$.

'D'Annunzio, "La Città Morta." 
of blood-red poppies, darker in hue than our own in Italy. I recall Atrides and Clytemnestra: ${ }^{\mathrm{I}}$

\section{"My sword I strive to wield, but strive in rain; \\ Nor did my traitress wife these eyelids close, \\ Or decently in death my limbs compose."}

By a strange contrast of history, the tomb of Clytemnestra returned to the light by the work of a most affectionate wife, and Schliemann dedicated to Sophia the account of their work together in the excavations of Mycenæ as a proof of his gratitude for the unselfishness, zeal, and energy with which she maintained his courage at a time of trial.

\section{VIII.}

Schliemann thought that his discoveries at Mycenæ had given a background of reality to the heroes of Homer ; instead of this they became more imaginary than they had been before, and history, leaving the poem behind, moved back suddenly to the most ancient period of Mediterranean civilisation.

It is now generally agreed that the walls and tombs of Mycenæ are earlier than the Homeric poems. Among the opponents of this view I recall (with the great respect which is due to him) Tsountas, who with a few others remained faithful to Schliemann.? A more important point in studying Mycenæ is to understand that these tombs indicate a period of distinct decadence in art and that this civilisation continued to fall lower in the scale until the period of the Homeric poems and rose again in historic times.

Schliemann found seventeen skeletons, of which three were of females. The daggers with damascened blades, the bronze swords engraved with scenes of lion and panther hunting, are certainly imported. Some slender swords of bronze, I metre

r Odyssey, book xi.

2 Tsountas and Maratt, "The Mycenæan Age," Boston and New York, 1897 . 
in length, are similar to those found in Crete and also to those found in Sicily by Professor Orsi. They are perfectly made weapons with a rib down the centre, and their length and the fineness of the blade show how far advanced was the art of tempering bronze. The score of gold cups and the silver ones which were found in the tombs were probably imported with these weapons. Achilles slew on the funeral pile of Patroklos twelve prisoners, who were to keep him company among the pale shades in Erebus; it is, however, not to be supposed that all the skeletons found in the tombs are princes. It was the custom to bury with the dead the things dearest to him; therefore we find in the tombs beautiful gold necklets, mirrors, great ivory combs, blue glass beads with gilding, filigree work, precious vases full of food, and objects for the use of the dead. The actual value of the gold found by Schliemann in the tombs of Mycenæ is above $f_{t}, 000$ sterling. This alone will show the wealth of the Princes of Mycenæ.

IX.

The vases belong to various periods, the tombs having probably been reopened at later dates, as was usual in Crete, for secondary interments. Schliemann found seven hundred discs of gold in the tombs of Mycenx. They are thin plates of gold leaf, rather broader than a penny, and worked in relief by a mould. The polypus, stars, and butterflies are identical with the designs on the vases and on the bronze axes in Crete. Others, in the shape of flowers, stars, or shells, were evidently made by the dozen. Professor Stais has recently expressed an opinion that all these discs of gold were not for the decoration of royal robes, but only ornaments applied to coffins; and this seems probable, for the discs and the rosettes could not be attached to woven stuffs, and the diadems and belts also are made of gold leaf of too thin a quality to be used in ordinary life as ornaments.

Schliemann found thirty-four bronze vases in one tomb, just as in the tombs discovered by Dr. Evans at Knossos ; in another 
tomb were two bundles of bronze darts, ten in each bundle. Even from this alone we may deduce the fact that the decimal system was used in Mycenæ, as we have seen was the case in Crete. No written tablets were found, and the same thing was the case with us in the Middle Ages, for after Roman times few men could read and write. With the Mycenæan things some very ancient objects were found: stone weapons, flint arrow heads, and many vases of marble and alabaster. One of these-a very beautiful example-possibly came from Egypt.

The terracottas representing animals or female images are also similar to those found in abundance in Crete, and which also reached Sicily and Italy.

\section{X.}

Far from being the expression of an early stage of art, the objects from Mycenæ show a heavy style of work and are too much stylised to belong to the infancy of a people. Any doubt on this point is removed by the close connection between Mycenæan and Minoan art; we are well acquainted with the phases and development of the latter.

The kings were not buried in their crowns, for these diadems could not have been put on their heads, and the holes by which they were nailed to the coffins are visible. In the same way the masks were not used to protect the faces from contact with the air, for they are made in the shape of a basin with the face moulded on the hollow, leaving a wide border in which the holes, by which it was fixed to the bier, are still visible. One mask has two wires passed through the ears, where they make four or five irregular turns. This is another indication of a more recent date than that of the tomb, for ear-rings were not found in Crete.

The greaves and bracelets of gold on the legs, the breastplates, the rings with which the fingers are covered, the spirals in the hair and the necklaces of amber show that these tombs belong to a much later period than that of the Cretan palaces. 
In all these ornaments there is a tendency to the spiral forms, which become a characteristic sign in the women's ornaments of the lake dwellings and of the most ancient of the Italic fibula. The artistic decadence is most clearly shown in the golden masks. Except one with the face of a man with beard and moustaches they all prove that there were no artificers in Mycena capable of modelling the face of a prince at his death. These masks are a childish and grotesque piece of work.

The horse did not exist in Crete in the early Minoan period, but, as Homer tells us, horse-breeding was largely carried on in the neighbourhood of Mycenæ. On a stele with spiral decoration found by Schliemann is a relief of a man driving a horse in a chariot. The horse is badly drawn and difficult to make out; no other trace of the horse was found in the excavations, but he certainly existed, because he was engraved on seals. In the Gulf of Argos, opposite Mycenæ, was a spring of water which bubbled up in the sea, and here from remote times the Argives sacrificed horses to Poseidon. On the wall of the palace was a painting of three men with asses' heads, yoked by a beam which they bear on their shoulders. This fresco, which is in the centre of a wall, painted in Pompeian style, with bands of red and yellow, proves how far the art of painting had advanced for satire to find a place among the subjects used in decoration.

Tsountas thinks that these men are wood-demons I like the fauns; they have, however, such a comic appearance with their tongues hanging out of their mouths, that I think I run no risk in saying that this is a genre painting, either a satire on man's credulity or the moral of a fable-a suggestion that men with asses' heads should bear the yoke However this may be, the painting proves the relations of Mycenæ with Africa, whence came the ass.

I Tsountas and Manatt, "The Mỵcenæan Age," p. 301. 


\title{
CHAPTER X
}

\author{
MYTHS AND RELIGIONS OF CRETE
}

I.

"Oh! temples of the Eternal mystery,

Oh ! eternal mystery of temples!",

Y O other country has so many or such varied and poetic 1 monuments to record the history of its religions. The Venetian churches were transformed into mosques. Built into the walls of the severe Byzantine edifices we find marbles from the Roman temples which had arisen upon the classical ruins of Hellenic altars. Still further back are the records of Mycenæan religion, and far in the darkness of ages the fetishes and idols of the Stone Age.

The excavations made by Mr. Evans to the right-hand side of the cart-road to Knossos brought to light an ancient sanctuary, and the idols found there (Fig. 8+) take us back to the origin of pre-Hellenic religion: one idol has a profile resembling that of a monkey, another that of a man. Dr. Flinders Petrie found similar figures in a temple at Abydos in Egypt. Near them was a terracotta image of a wild goat.

We need not be surprised that a civilised people should venerate misshapen stones such as those discovered by Mr. Evans, for we know what the Romans did with a stone similar to that which $\mathrm{I}$ found in the excavations of Phæstos. At the time of the 
second Punic War the Sibylline Books predicted victory if the black stone were brought to Rome.

An embassy of five Roman citizens was sent to Pergamos, and to these men, who were to be the "best men in Rome," Attalos handed over the sacred stone, which was probably a meteorite I the size of a man's fist. When the black stone arrived in Italy (in the year 205 B.C.) a great festival was held. The Roman matrons and Publius Scipio Nasica went in procession to Ostia with prayers and incense. On arriving at Rome the black sione was deposited in the Temple of Victory

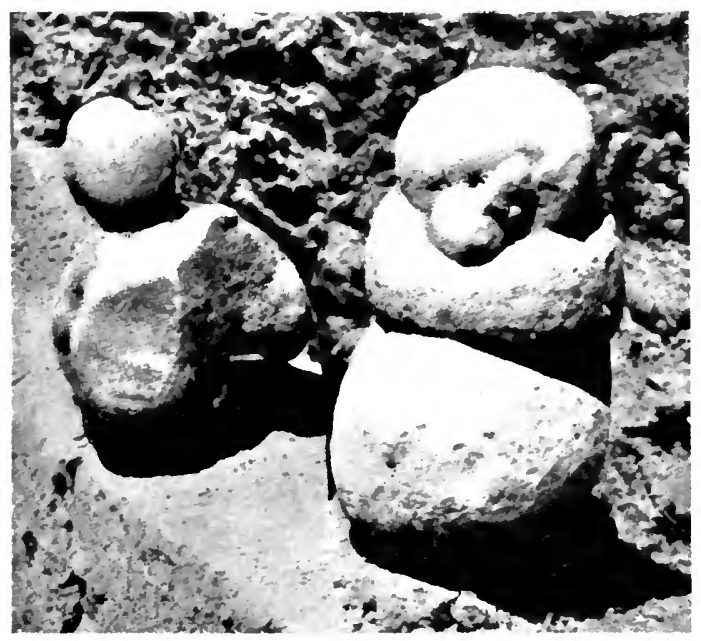

FIG. 8+-STONE IDOLS FOUND IN A SANCTEARY AT KNOSSOS BY DR. EVANS.

on the Palatine, and the Templum Magnæ Matris was built for it. This temple was rebuilt later on by Augustus after a fire. Thus did the cult of stones and of the Mother of the Gods spread as far as Rome.

\section{II.}

The legend sung by Hesiod of Kronos, who devoured a stone in Crete under the idea that he was swallowing his

"Arnobii, "Adversus Nationes," liber vii. 49, says "nisi lapis quidam non magnus, ferri manu hominis sine ulla impressione qui posset, coloris furui atque atri, angulis prominentibus inaqualis." 
son Jupiter, would have no point had the cult of stones not existed.

The dolmens of Otranto ${ }^{\mathrm{I}}$ are the mile-stones of this worship as it spread towards the north of Europe, as far as Carnac in Brittany and to Scandinavia ; 2 it was so deeply rooted among the northern peoples that Charlemagne had to prohibit the worship of stones. The axes which are carved on the columns of the palace of Knossos are also found engraved on the megalithic monuments of Brittany. 3

Pausanias mentions stones which have fallen from heaven, 4 and in Genesis vi. there is an allusion to the worship of stones. Jacob arrives towards sunset at a place where there are many stones; he lies down, and in his sleep has a vision. On waking he sets up the stone on which he had rested his head and anoints it with oil 5 in commemoration of his wonderful dream. The place receives from him the name of Bethel, "dwelling of God," a Semitic word which resembles the Greek word Bairvios. The sacred stones set up by the Hebrews when they established themselves in the Promised Land are still to be seen on the banks of the Jordan. ${ }^{6}$

The influence of Mycenæan civilisation on Rome is seen in the image of Jupiter represented as a stone, Juppiter Lapis, from the remotest time.

\section{III.}

Although I had no definite object before me and simply took things as they came, religious questions were constantly coming before me.

On descending the northern staircase at Knossos two pillars are visible in the furthest parts of the excavations, in the middle of a

I "Pigorini, monumenti megalitici di Terra d'Otranto," Bolletino di Paletnologia, tomo v. anno xxv. p. $178,1899$.

${ }^{2}$ De Nadaillac, "Les Premiers Hommes," i. $3+0$.

3 P. I60. These stones are designated Menhir and Cromlech when they are circles formed of uncut stones fixed in the ground.

4 VIII. $48,6$.

5 Genesis xxviii. 22.

${ }^{6}$ Perrot and Chipiez, "Hist. de L'art," iv. p. 379. 
small building with well-preserved rectangular walls. According to Dr. Evans this little sanctuary was devoted to pillar worship. Three of its doors open on the front of the palace and two on the interior.

Near the breach time has transformed the ruins into clay, and the thousands of years of vegetation have produced a red and fruitful soil. A field of barley full of poppies and gladiolus resembled a pomegranate split open. Spring, with her rich cloak of flowers and greenery, spread out a part of it as far the threshold of the temple.

The sacred pillars are of the height of a man and are 50 centimetres in diameter, with obtuse angles, and stand on a square marble base. Crystals of gypsum glittered on the pillars like silvered laurel leaves, and prismatic colours were reflected from the glassy surface of the gypsum.

In the cutting I sought for a record of the centuries which had passed over the ruins of the temple. Near the top I found a piece of an Arretine vase, or perhaps a cup, of very fine red clay, and at the depth of I metre below the floor a yellowish sherd; I picked it up, and saw painted on it in the Mycenæan style the head of a polypus with great round eyes, from which proceeded the tentacles winding in spirals.

The Etruscans also practised pillar worship, for pillars which do not reach the ceiling are found in their tombs. I Mr. Evans gives illustrations of sacred pillars found in Malta 2 and in Macedonia.

\section{IV.}

The form of the Mycenæan temples is shown on many seals and in the fresco found by Dr. Evans in the palace of Knossos 3 (Fig. 85). The space round the small temple is full of miniature

I There is a reconstruction of one of these in the Archæological Gardens at Florence in a bee-hive tomb from Casal Marittimo, published by Milani in "Studi e Materiali."

2A. Evans, "Mỵcenæan Tree and Pillar Cult," Fournal of Hellenic Studies, xxi. 99,1901 .

3 Evans, Fournal of Hellenic Studies, 9011 , xxi. p. 192. 
figures of men and women. On a white base stands the wooden building with polychrome decoration of blocks of black and white stone, and above it the characteristic long-shaped rosettes like those of Mycenæ and Tiryns. On the upper part are two wooden pillars, and between them the sacral horns, which are also found below; on the right and left are other pillars in Mycenæan style. Dr. Evans notes the resemblance of this fresco and the golden altar with the doves found by Schliemann at

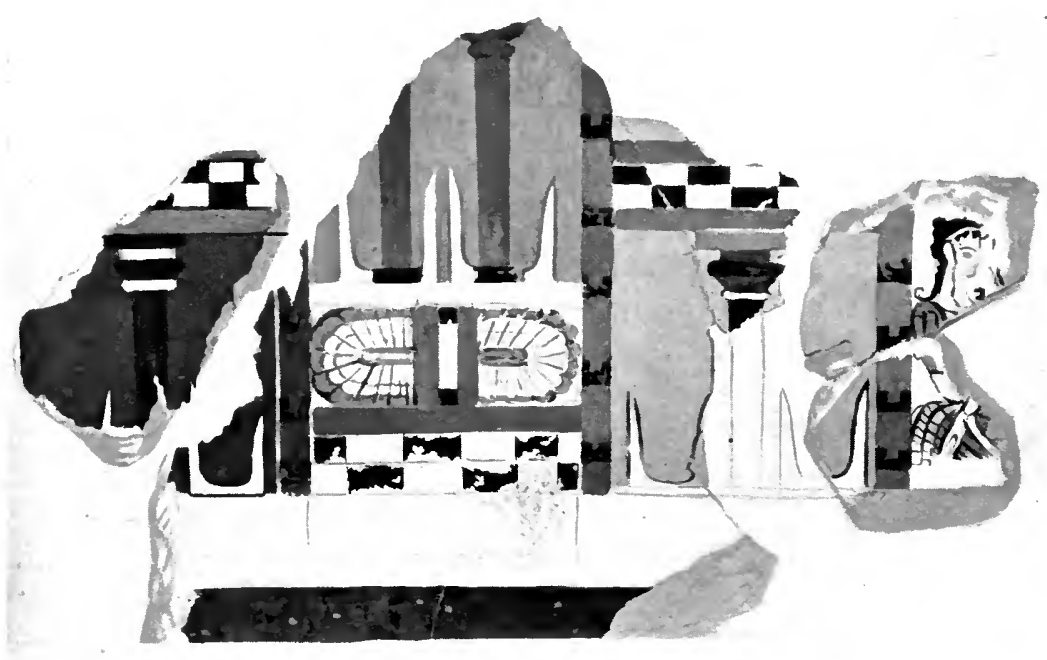

FIG 85.-FRESCO FROM KNOSSOS REPRESENTING A TEMPLE FOR PILLAR WORSHIP.

Mycenæ. The woman sitting at the window, with her back to the little temple, will give an idea of the dimensions of this building.

A steatite vase, with a procession carved on it in low relief, was found by Dr. Evans at Knossos. ${ }^{I}$ Two youths, each holding a cup for the offering of the sacrifice, pass before the sanctuary (Fig. 86). The solemn approach of the youths is wonderfully expressed by the artist, and the characteristics of

r “Knossos Excavations," 1903. 
Mycenaan style are shown in their appearance; the trunk is nude, and a long tress of hair hangs down the back.

The sacred edifice, built of stone and wood, with architectural

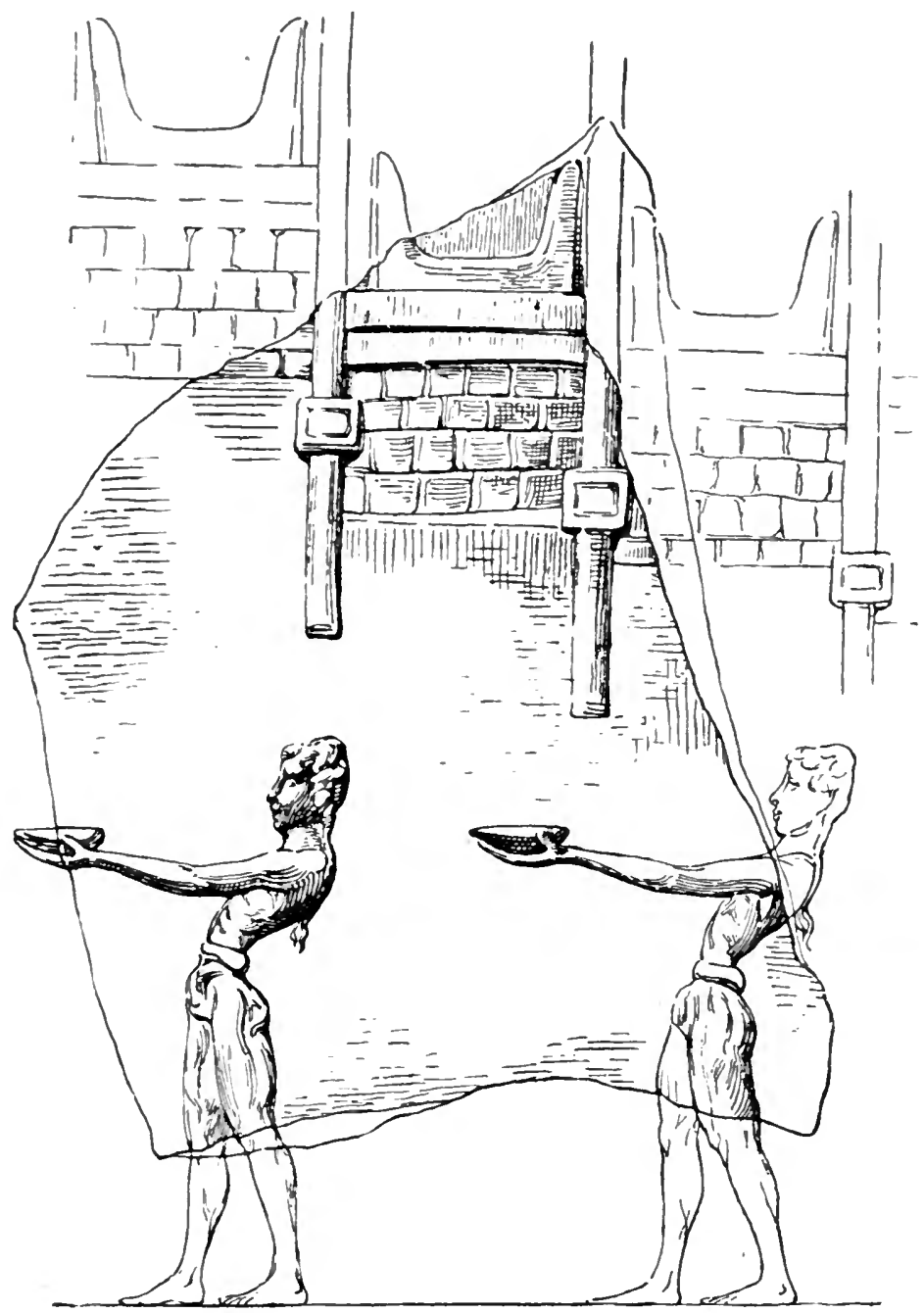

FIG. 86.-PROCESSION BEFORE A TEMPLE. K.ossos.

decoration at the base of the shafts, has the sacral horns between. These horns are also found in the ancient monuments of the people of Israel, reproduced in Dr. Evans's book, and numerous 
examples of the same were found at Mycenx. This is one of the few examples of animal symbolism in the Mycenæan religion, and is possibly a record of the sacrifices. At Hagia Triada many oxen of bronze were discovered, and I give one which was found by Dr. Pernier (Fig. 87). Instead of a live calf, it was more economical to offer up one of bronze, terracotta, or porcelain, with gilded horns. Figures of oxen with a star or an axe on the forehead have been found both at Mycenæ and in other parts of Greece. The great difference from the religion of Egypt is seen here: the beasts were offered to the gods, and

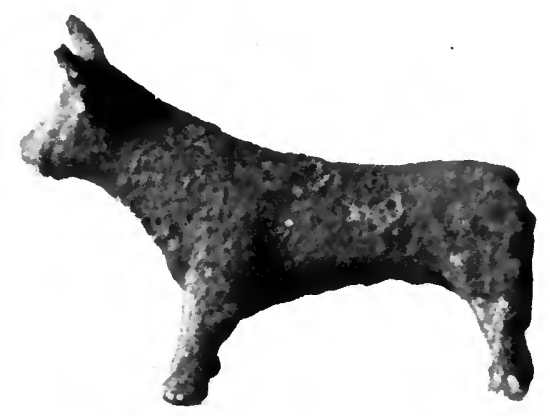

FIG. 87.-BRONZE FIGLRE OF A CALF FOUND IX THE VILlA OF HAGIA TRIADA.

the images were the sign of the sacrifice; the Egyptian, on the other hand, deified and adored animals from the bull Apis to the crocodile, from the hawk and the ibis to the lion, the jackal, and the monkey.

The study of religions is an important part of ethnology. Here, on the one hand, we see the intellectual rigidity of the Egyptian - their caste system, the ruling theocracy, the mummification of a people crystallised in their formulas; on the other we have the great artistic flexibility and the freedom of physical and intellectual life of the Minoan people. 
Among the seals from Hagia Triada we saw a woman ${ }^{1}$ (Fig. 3I b), wearing a full bell-shaped gown with flounces and fringe, with her hands resting on her hips. Beside her stand two children in the same attitude and costume. This may represent a religious dance in front of a small temple with two pillars, with the triple-branched sacred tree in the middle. Dr. Evans found a similar intaglio in a ring at Knossos: there is the temple, from which rise three trees, and a woman in an attitude of adoration. ${ }^{2}$

In the pyxis described by Dr. Evans we see by the leaves that

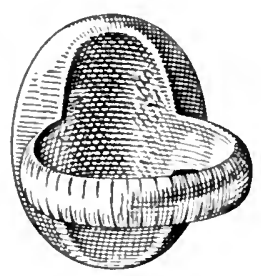

FIG. $88 a$.

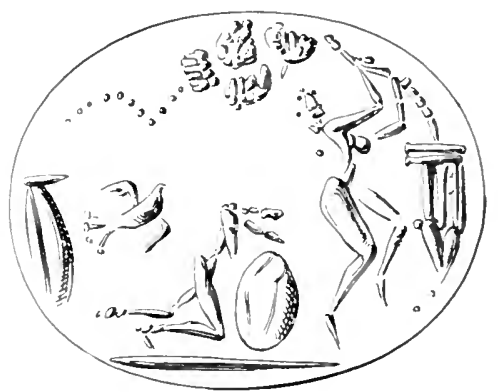

FIG. $88 b$.

GOLD RING WITH IESIGN OF SACRED TREE AND BATYL FOLNI AT PHÆSTOS.

the sacred tree in the temenos is a fig tree, and the position of the altar near the enclosure of the tree proves that this fig belongs to the sanctuary. On the sarcophagus found at Hagia Triada by the Italian Mission there is a tree in front of a small temple. The tradition of the sacred fig-tree came to Rome with the ficus ruminalis of the Forum.

The Pelasgians and Etruscans brought tree-worship to Italy, as we see in the most ancient tombs of Tarquinii, where the trees always appear decorated; the forests of Dodona and the sacred

I F. Halbherr, Monumenti Antichi, R. Accad. Lincei, 1903, vol. xiii. fig. 3\%.

$=$ Evans, Fournal of Hellenic Studies, xxi. p. I 70 . 
wood or grove surrounding many of the temples in Rome have their origin in this cult.

At Pompeii there is a painting representing the sacred myrtle of Aphrodite placed against an elegant column. In front is an altar for the sacrificial offerings, above it an amphora, below a syrinx, and higher up on the trunk a band with the dionisiac emblems.

The gold ring (Fig. $88 a, b$ ) found in the necropolis of Phæstos I is an important document as regards pre-Hellenic religion. In a small enclosure stands a sacred tree which is bent down by a nude woman, who is holding and shaking it, while

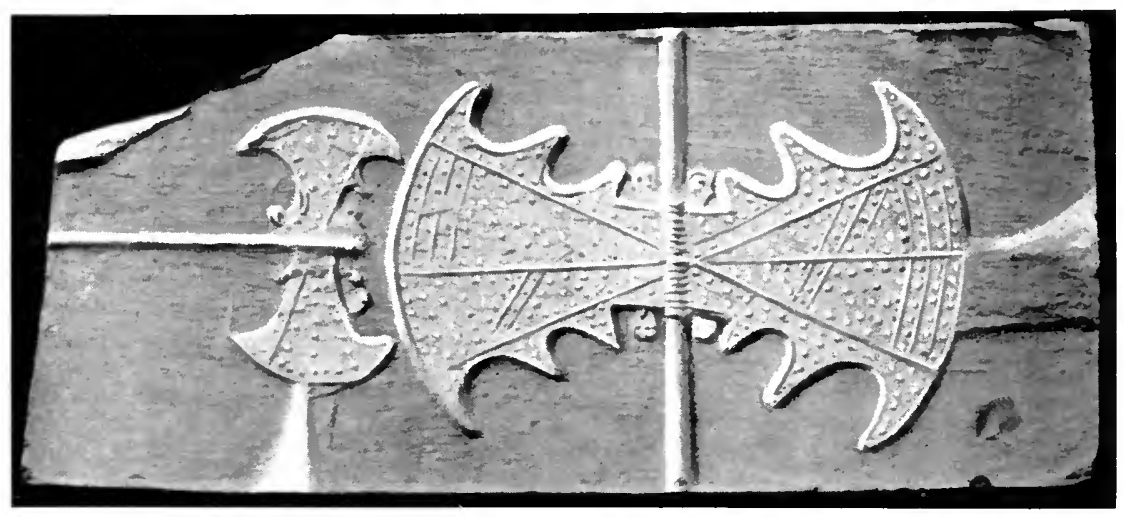

FIG. $89 a$ - MOLLD FOR CASTING VOTIVE AXES 1N BRONZE.

fruit is falling from the tree. Behind this woman is another figure, kneeling and embracing a stone; on the left is a bætyl, and a dove flies towards the sacred tree.

\section{VI.}

The double axe worshipped on the altars is the symbol of the ruling power of the Universe. ${ }^{2}$ Figs. $89 a$ and $b$ show two moulds

" Savignoni, Monumenti Antichi, vol. xiv. p. $57 \%$, fig. 50 . The intaglio is three times the actual size, and the ring $(50, a)$ one and a half.

${ }^{2}$ Small votive axes, which can only have been used for ornament, or as cultus objects, were found in Sicily at Castelluccio (Bulletino di Paletnologia, 
used for casting the double axes. The holes through which the liquid bronze flowed and the studs by which the two halves of the mould were held together are both visible. They are for two small axes with a design of lines and small points. These axes resemble those on a gold ring found at Mycenx, which has given rise to much discussion on account of the figures round it. The embroidery of the skirt worn by the woman resembles that on a modern fashion-plate, and is important for the study of feminine attire.

At Hagia Triada Professor Halbherr found more than half of one of the great double axes which were mounted on long shafts and carried in the religious ceremonies, or set up on pyramidal bases in the sanctuary. ${ }^{1}$

To speak of Crete and of Minos without referring to the Labyrinth would be inexcusable forgetfulness. At Knossos I bought from a peasant a silver coin bearing the device of the Labyrinth. It is a quadrangular figure formed of complicated lines, which weary the eye if one

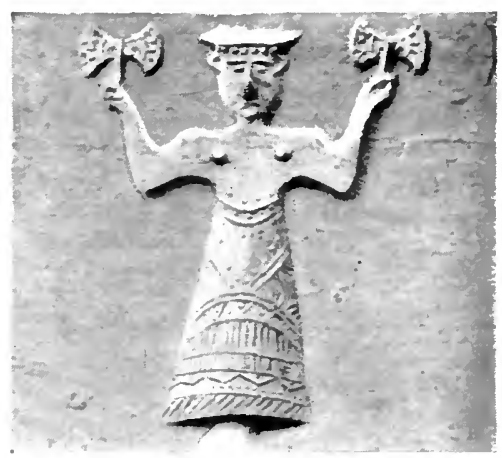

FIG. 89b.- MOLLD FOR CASTING IN BRONZE THE FIGLRE OF A WOMAN HOLING TWO AXES. attempts to follow them. It was the emblem of Knossos, but the famous Labyrinth has not yet been discovered.

Herodotus was the first historian to mention the Labyrinth in the city which the Greeks called Crocodilopolis. The legend of the Labyrinth probably originated in an erroneous idea as to the object of the Egyptian constructions of the XIIth Dynasty.

Herodotus, who had seen the ruins of these buildings, alludes

xviii. pl. ii.), and at Plemmirio (ibid, xrii. pl. x.). Axes, so thin that they could not have been used for any kind of work, and were probably sacred axes like those in Crete, have been found at Bologna and in many other parts of Italy.

I Rendiconti R. Accademia dei Lincei, 1905, vol. xiv. p. 353. 
to the fable of the Labyrinth, and says they were great reservoirs for the waters of the Nile. After four thousand years the English have reconstructed the system of cataracts and canals and doubled the value of the land, for the waters of the Nile now render fertile the ground which was till now barren.

As the Labyrinth has not been found, the explanation given by $\mathrm{Mr}$. Rouse I is most probable. Everywhere on the walls of Knossos we find the sculptured double axe, labris in the Carian language-and so the name of the house of the double axe was Labyrinth.

\section{VII.}

In the villa of Hagia 'Triada, on the northern boundary of the site, is a small square building with strong walls, left rough on the inside, which Professor Halbherr believes to have been the temenos, or enclosure of the sacred tree. ${ }^{2}$

Every day on the way to the Mycenæan villa I passed a curious tree covered with fetishes. This, too, is a sacred tree. Near a ruined church stands an olive tree hung with bits of rag which the peasants tie on the branches, hundreds of shreds of every colour, worn by the rain and wind. I often stopped to look at it, and imagined myself back in Mycenæan days. The ground, too, covered with asphodel, recalled a scene in Erebus where Minos appears to Odysseus: 3 " in meadows clothed with asphodel."

At the foot of the ancient trunk the shoots were all tied up with knots of various colours. There were pieces of black woollen stuff, red handkerchiefs almost whole, bits of ribbon, and numerous scraps-a regular assortment of samples of the poor stuffs of which the peasants' clothing is made-all abandoned to the weather.

I asked what the curious decoration of the tree was, and was

I Rouse, "The Double Axe and the Labyrinth," Fournal of Hellenic Studies, vol. xxi. p. 268.

${ }^{2}$ Halbherr, Rendiconti R. Accademia dei Lincei, April 15, 1906.

3 Odyssey, xi. 
told that any one who suffered from malarial fever binds it to the tree with a shred of his clothing, a handkerchief, or a ribbon, and says a prayer, ${ }^{1}$ hoping to be cured thereby. From the old olive tree some shoots of wild olive were sprouting below the point where the olive had been grafted. These branches have smaller, greener serrated leaves ending in a prick. Faith is stronger in this wild part of the plant, for the thorny branches are bound round all the way to the ground with rags, which shine with the slime of snails or are closed in and wrapped round by the web of insects.

I saw a woman on her knees praying: so the cult of trees is arising again, for the human soul is unchangeable in its aspiration towards the mysterious, and is overcome by terror in the struggle against the blind and murderous forces of Nature.

\section{VIII.}

The caverns of Mount Ida, of Mount Dicta, and of Kamares are connected with the origins of the Minoan religion; the altitude of these sacred places gives an idea of the poetic feeling for Nature which was ingrained in the people. In the cave of Mount Dicta was a libation table, and the excavations made there by the British School of Archaology have brought to light a great number of double axes, the votive weapons sacred to Jove. But no human image of the divinity was found, and this fact accentuates the purity of primitive religious feeling. At Præsos, too, as well as on Mount Ida, Professor Halbherr found a place set apart for worship, with numerous ex voti of terracotta, but no trace of the existence of any temple in the vicinity.

This year a stone discovered by Mr. Bosanquet in the temple of Jupiter Dicteon at Palaikastro was put up in the Museum of Candia. It is a grey marble tablet with an inscription on both sides copied from an identical but more ancient inscription. I

I Witchcraft is common in Crete. Rags and dirty bits of stuff, into which the witches profess to have banished diseases, are constantly found in holes in the walls of the churches. 
give the translation of the first part, which records the birth of Jove in Crete:

"Hail, O great child, son of Kronos, omnipotent, who cometh yearly to Dicta seated on the hyena, escorted by demons. Accept the song which we raise to thee accompanied by the lyre and flute, standing round thy altar, $\mathrm{O}$ benefactor.

"In this place the Cureti received thee, O immortal child, from the hands of thy mother Rhea."

Hesiod relates how Rhea saved Jove as a child from the fury of his father Kronos, ${ }^{I}$ or Saturn, who represents the mystery of time, the dark and measureless abyss of ages, before all divinities. From Saturn and Rhea were born Vesta, Ceres, Hera, and Jupiter. It had been foretold to Saturn that a son of his should overcome him, wherefore he devoured them as soon as they were born.

When Jupiter was about to see the light, heaven and earth were moved by the prayers of Rhea and sent her into Crete among the fat people, as says Hesiod.

IX.

From the terrace of my rooms in the inn at Knossos I can see Mount Dicta where Jupiter was born, Mount Ida where he was brought up, and Mount Joukta where tradition locates his tomb. There is a depth of philosophical thought in this landscape which overcomes me, and every evening I return to gaze again on the violet coloured heights of Mount Joukta. The great dome of the mountain (Fig. 90) above the ruins of Knossos is truly worthy to be the tomb of a god. Kronos has conquered, for Time has destroyed the king of Olympus. In the "Theogony" of Hesiod (where the most ancient religious traditions of Hellas are best preserved), first there was chaos, then earth, and love who conquers every deity. Kronos, father of the gods, is greater than all, for Time is like the river which surrounds the earth, which flowed before all things and will go on flowing for 
ever, bearing away on his immortal flood men and gods. Jupiter was not yet born when the Minoan culture flourished. Knowing certainly of the supreme power who rules the world, men had then a higher ideal, and none thought of making a man of this power. Anthropomorphic conception came later, and marked the decadence of religious thought in the Greek mythology.

The primitive religion of the Cretans probably differed little from that of the Romans, in which in remote times there was no personification of divinity. ${ }^{\mathrm{I}}$

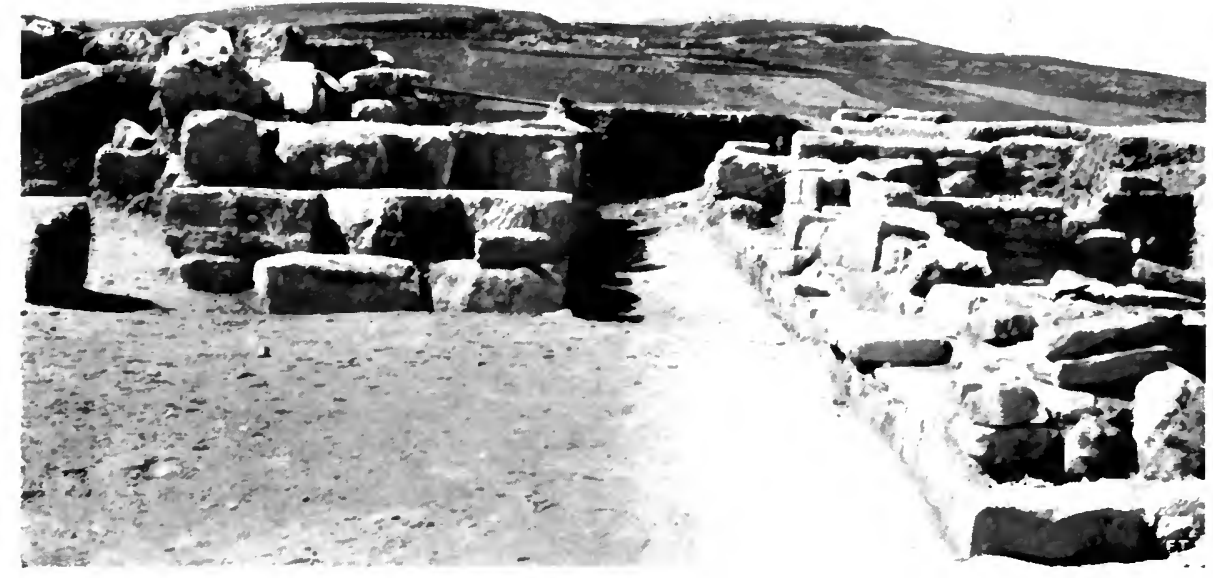

FIG. 90.- MOLNT JOLKTA FlROM KNOSSOS.

This cult has a practical tendency, and the torces and various aspects of nature are worshipped without abstract ideas; religious forms and conceptions follow the same historical process, which agrees with the psychical evolution of the peoples. Varro has said that for a hundred and seventy years the Romans worshipped the gods without images. They were satisfied with a rock to indicate Jupiter, a spear for Mars, and fire as a symbol of Vesta.

'G. Wissowa, "Religion und Kultus der Roemer," p. 20, München, 1902. 
We are told that the Aryans brought with them to the land of Hellas the belief in a supreme god, a luminous god, Zeus, and that this name is connected with the Sanscrit Djaus; that in the Indo-Germanic languages there is the root di (div), signifying to shine, and that the Aryan people brought us this god of heaven. I know nothing about philology. But I do know that before Achilles gave up his arms to Patroklos he uttered a prayer in which there is no indication of the pagan element and invoked "Pelasgic Jove" as if he were a national god. ${ }^{1}$

The Aryan people knew not the sea, which has a fundamental importance in Minoan religion, and only through this cult can it be understood how Poseidon should have been placed beside Jupiter on an equal footing in the hierarchy of the gods.

In the study of archæology we find no period in which we can fix the appearance of Zeus.

If an invading people (as the Aryan people must have been) had entered Crete, we should find traces of them, but on the other hand we can follow the complete evolution of the national divinity. Zeus keeps the title of Pelasgic-Homer speaks of the good Pelasgians, and here also tradition is quite opposed to the idea of an invasion. Pausanias 2 relates that the temple of Zeus in Olympia, one of the most ancient and famous in Greece, was connected with the cult of Zeus on Mount Ida, and was founded by Herakles of Crete. At night as I looked on Mount Ida in the poetic light of the full moon, the blue peak which reaches up among the shimmering stars behind the silver mantle of snow, I thought of Anchises seeking in this isle the cradle of the Latin race.

\footnotetext{
"Antiquam exquirite matrem. .... et spes discite vestras.

Creta Jovis magni medio jacet insula ponto, mons Idaeus ubi et gentis cunabula nostrae." 3
}

\footnotetext{
I Iliad, xvi. 233, Zદẽ ă

2 V. I 3, 8.

3 Eneid, iii. 105.
} 
Without the excavations in Crete we could never have understood one of the strangest things in the Homeric poems, which, though held as the song of a people in its youth, show a marked deficiency of religious feeling. What these bards have sung is rather a critique of the myths than veneration of the gods. From the first lines of the Iliad, Chalcas-

\footnotetext{
"Wisest of seers to whom all things

Were fables that were, that are, and shall be,"
}

shows that Apollo sent the pestilence into the camp of the Greeks.

Agamemnon, I the free-thinker, rises angrily, saying : "Prophet of evil, from thy mouth has come no welcome word. Thine evil heart has ever joyed in presage of disaster, and thy deeds are devoid and bare of honour as thy words."

This haughty tone in addressing a great priest is a grave symptom and shows the irreligious spirit of the Greeks. The morality of the gods is low, and the life of Zeus himself seems to be full of unsavoury adventures. The gods are inferior to men in moral sense, for they are liars and traitors. It is no libel to say that the gods of Olympus are not respectable folk. The impious satire of the gods as we find it in the Homeric poems was only possible after long evolution of religious thought.

The anthropomorphic tendencies in the religions of Greece and Rome (and also in Catholicism) have lowered the primitive idealism, which does not represent gods in human form. Jupiter fastens an anvil to his wife's feet, and when the gods rebel he has to turn to Briareus for help. No man of the Homeric age would have stooped to the deceit, the tricks, and plots and crimes which this Jupiter, the cloud compeller, practises for the sake of sensual gratification. The loyalty with which Achæans and

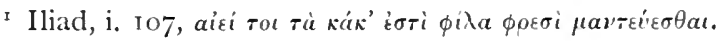


Trojans treat their enemies is in strange contrast with the perfidy of the gods.

Andromache is far nobler than the goddesses in heaven; and the words she addresses to her spouse are unforgettable. Penelope, too, attracts us strongly by her nobility. Near the sublime goodness of these mothers, the goddesses are like low courtesans. The religion of the Homeric poems proves that the Iliad and Odyssey do not show us the infancy of a people or the beginnings of a culture. Religious feeling had already passed through a long period of development, and the Homeric bards sang at a time when religion was already decadent.

The excavations in Crete have thrown new light on the history of mythology. The theory most relied on to explain the strangeness and immorality of classical mythology was that of the allegorists or symbolists, who considered that the legends of the gods were fanciful tales invented by the Hellens, or that these legends came from the East and contain the precepts of exalted wisdom beneath the veil of fable. ${ }^{I}$ Others, among them Mr. Gladstone, have imagined that traces of a perversion of the biblical revelation might be found in classical myths. Modern archæology clears away this confusion. These gods are not deified men, heroes exalted by imagination to the celestial spheres.

Classical mythology is not a corruption of primitive monotheism, nor is it an importation of the Aryan race, but the degeneration of the primitive beliefs of the Cretans and of the myths which arose in the isles of the Ægean, and of the legends which grew up on the shores of the Mediterranean. The phenomena of life, the affections and the personification of the forces of nature were the primitive source of classical mythology.

\section{$\mathrm{XI}$}

When we read the Homeric chants we must think of the minstrels passing from one court to another in the isles of the Ægean, in Greece and in Crete, singing the deeds of the heroes.

\footnotetext{
I Ramorino, "Mitologia Classica, Manuale Hoepli."
} 
The Achaans were a jovial people who enjoyed good eating and better drinking, and spent long hours at the table, while a poet sang of the deeds of gods and men. In the Odyssey, Demodocus the poet sings before many hearers of the secret love of Venus and Mars, ${ }^{1}$ and the war-god says brutally that he overcame her with many gifts. The gods of Olympus come, on the invitation of Vulcan, to surprise the faithless wife, "with unextinguishable laughter," says Homer : and gay Apollo follows with a licentious pleasantry.

Contrary to the use of classical times, women were present at these banquets. I recall the assembly presided over by the famous Helen, and we need not be surprised if at such feasts the poets ventured to joke at Olympus and to take pleasure in the amorous adventures of the gods. We can understand the refusal of Odysseus to drink the ambrosia which would render him immortal. For seven years Calypso lavished love and caresses upon him, but Odysseus ever thought of his far-off wife, and would not exchange his human nature for that of a god.

Irreligion was a concession of the poets to the sceptical spirit of the crowd before whom they sang. In the apotheosis of human nature lie the germs of the Greek philosophy which was to renew the world. The oracles have little influence, and presently we find divination by augurs spreading till it becomes an essential part of the religion of the Etruscans and Latins. The genius which made of Greece the cradle of philosophy, of literature, and of the arts was the secular spirit, and the absence of that superstitious formalism of the sacerdotal caste who kept a firm hold on the most ancient societies of the East.

\section{XII.}

"Monastery of S. George in Phalandra, May, 1906.

"On the road by which I return from the excavations I stop to look at the ruins of the Monastery of S. George (Fig. 9I). Over the grey sky pass threatening clouds, and at sunset the

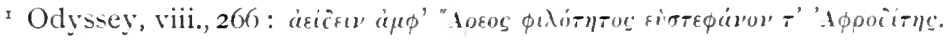


glorious sun lights up the ruins and sprinkles them with golddust. The ruins stand forth in greater majesty against the darkness of the shadows. A new life awakes in the walls like a vision-the sacred apotheosis of the past. In front of the convent the ground is covered with yellow marguerites, which bloom among the stones and enclose the ruins in a poetic frame. To the left some fig trees with their dense foliage wrap the belfry and porch in shade.

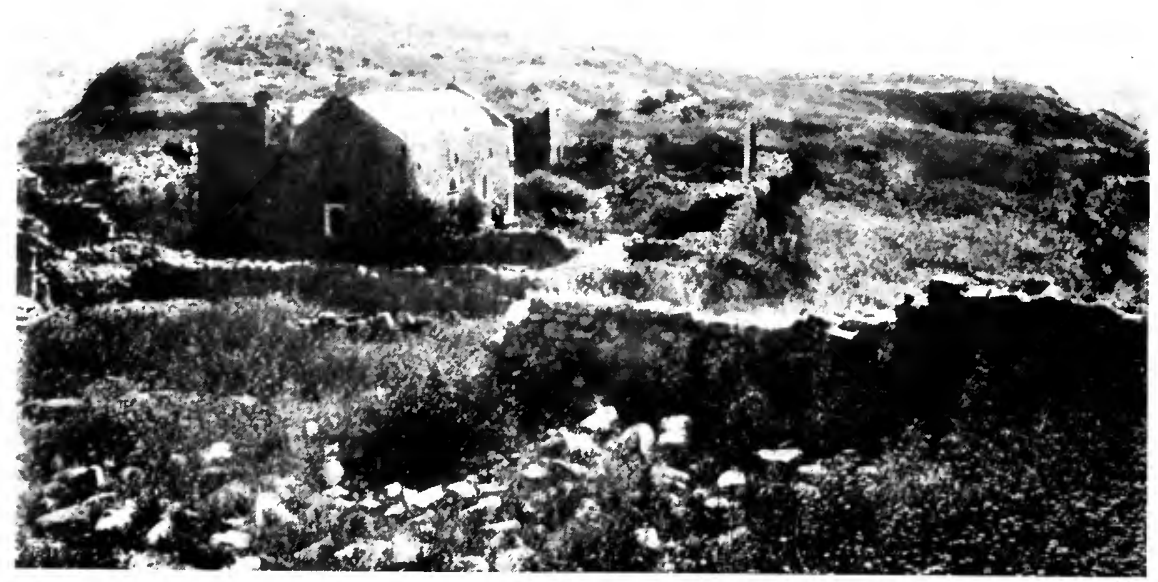

FIG. 9I.-NIONASTERY OF S. GEORGE ON THE HILL OF PHASTOS.

"The Cretans come from a distance to carry off the carved stone cornices with pure fifteenth-century mouldings to place on their window sills or round the doors. The church is still preserved by the strong construction of the vaulting, and round the church are the convent cells with elegant architraves. On the wall I saw a drawing representing a trireme, and I copied it in my pocket book, for it is a record of Venice which will soon disappear. 
"In front of and inside the church the graves of the monks are covered by great slabs of marble with rosettes at the corners. T'wo tombs at the side of the church are uncovered (Fig. 92), and on the greater is a coat of arms. A skull, bleached white, lies within the marble urn, and from the empty eye-sockets the fixed and mysterious glance of death throws contempt on the vanity of the world.

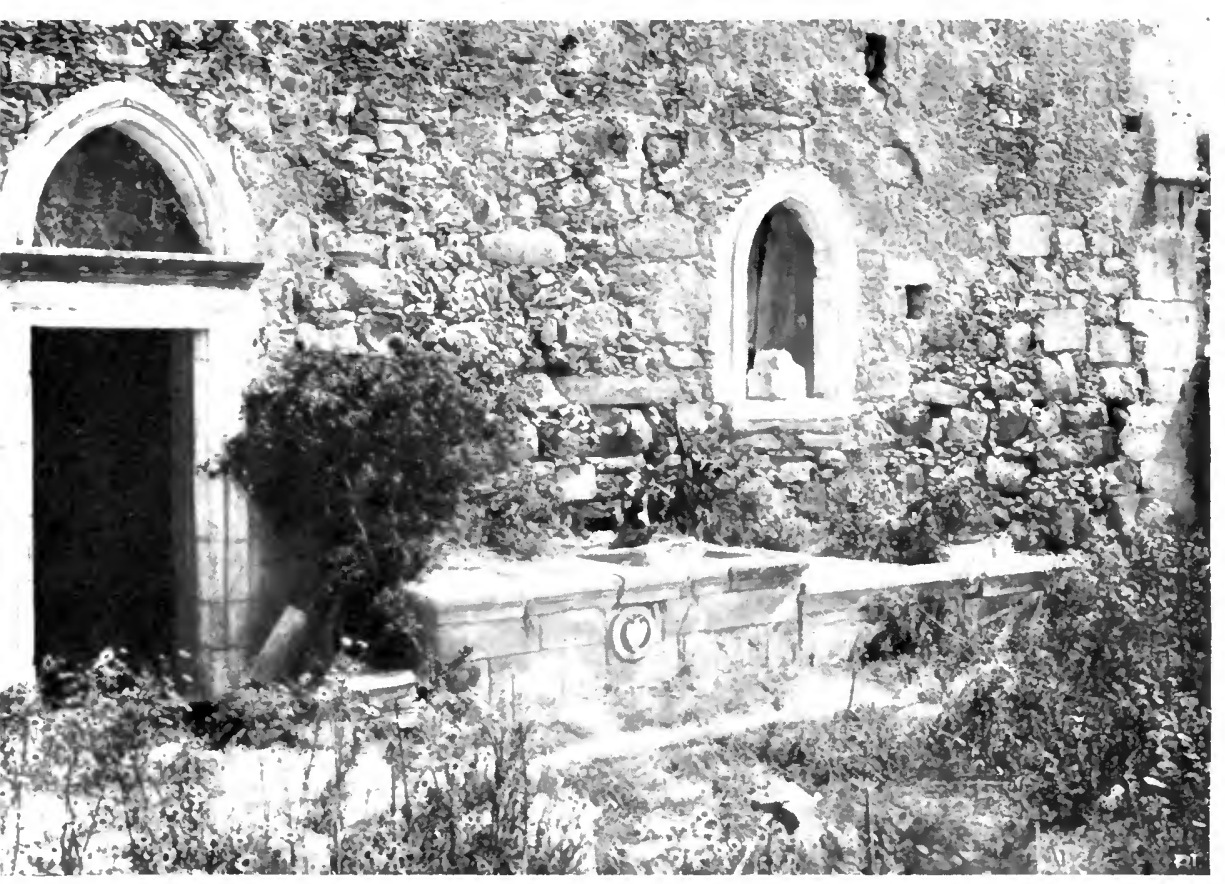

FIG. 92.- TOMISS OF THE MONKS OF S. GEORGF.

"Near the head blooms a tall rose bush in full flower. The monastery had passed under the Turkish dominion, the monks were turned out, the walls of garden and cell broken down, sheep had entered the sanctuary, the bells were silent, the cross had fallen from the top of the church, but in the midst of the ruins this rose lived on like the poetic image of the glory of long ago. 
"The yellow marguerites form a hedge round the pillars of the broken cistern, which has the date I 700 cut on a stone above. The bitter mugworts rise like pyramids of grey leaves among the yellow grain between the walls; only the rose bush, with its laughing petals and the sweet scent of its flowers, stands there as a kindly memorial, beautifying and overcoming the desolation of death." 


\section{CHA P T R X I}

BULL-GRAPPL1NG

I.

1 CONICAL vase of steatite found by the Italian Archæo4 logical Mission I in the excavations of Hagia Triada (Fig. 93) is the most complete monument that we have of gymnastic exercises in Mediterranean civilisation.2 The reliefs are divided into four zones. Beginning at the lowest we find a boxing scene, with the attitudes of the modern prize ring; in the second and fourth zones are columns with a rectangular impost which has a border of small circles, representing the portico of a courtyard. The columns taper upward in Greek fashion, while those which we have noticed in the preceding chapters are conical, and therefore wider above than below.

The great bull in the last division but one made a strong impression on me and was the reason of this study. Having copied from life the profile of a gigantic bull, the artist, in order to keep the proportions right, has reduced the figure of the man who is on the bull's head 3 (Fig. 94) to half the size of the other men.

The attitude of the gymnast may be explained in several

I Halbherr, Rendiconti R. Accad. dei Lincei, vol. xiv. pp. 365-405, 1905.

2 Height 45 centimetres and width 16 centimetres at the mouth.

3 'The artist, Dante Paolocci, drew Fig. 94, which shows this part of the vase one-third less than the original, from a plaster model. 


\section{$2 I 2$ PALACES OF CRETE AND THEIR BUILDERS}

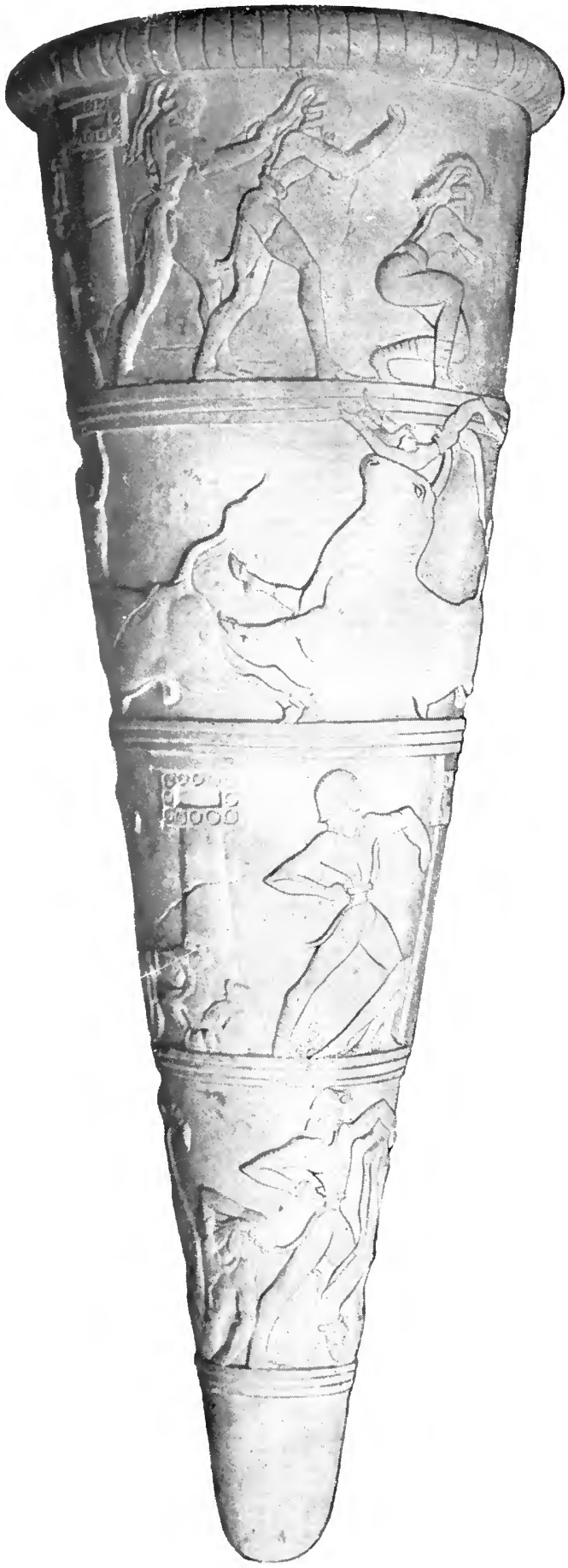

ways-either he was standing on the back of the bull and sat down on the head astride of the horns, or, finding himself upon the beast opposite, he had sprung on to the back of this bull, which had thrown up its head in order to reach him with its horns; or, it may be that these men were such skilful gymnasts that with a running jump they could spring upon the head of a bull with a single leap. The presence of the bulls among fighting gladiators proves that it is not a bull hunt after wild bulls. The freedom of movement and the contraction of the muscles in this gymnastic action assure us that the man is not injured. The attitude is exactly that of a man who has just taken such a leap.

For the complete appreciation of this vase we must recollect that it was overlaid with gold leaf, which gave it the appearance of solid metal. A similar vase of steatite was found at Palaikastro, and a thin piece 
of gold leaf can still be seen in the ear of one of the figures upon it.'

The chiselling on the gold leaf which would give more distinct projection to the relief is absent; but the composition, design, and execution are perfect, and the character of the bull is expressed with truth.

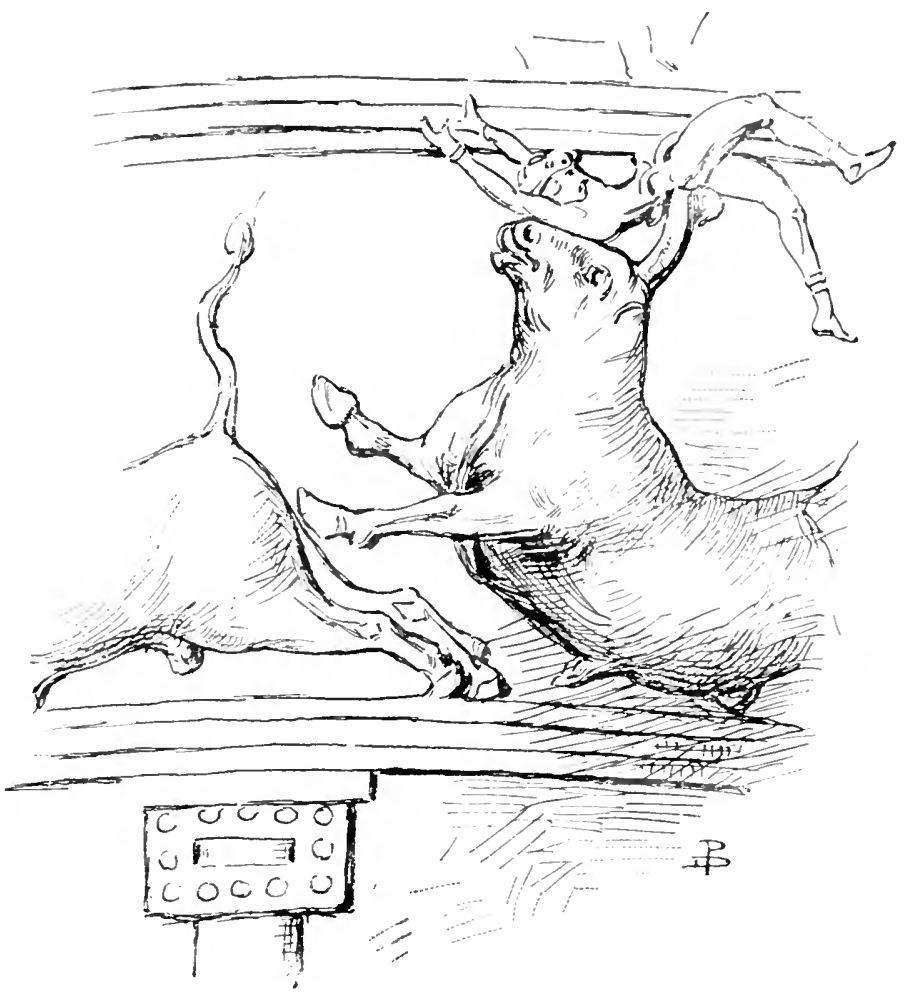

FIG. 94-DETAIL, ( $\frac{1}{3}$ LESS THAN THE ACTCAL SI\%E) OF THE BELL GRAPPLING SCENE FRON THE VASE FROM HAGIA TRIADA.

II.

The Cretan gymnasts made their somersault on to the bull either direct through the air, or by vaulting, resting their hands

I At first only a few fragments of this vase were found, and the following year nine more pieces turned up. This shows that treasure hunters had searched the site after the destruction of the villa and had broken up the vase for the sake of the gold. 
on the bull's back. A similar caper is represented on the seal discovered on a bracelet by Dr. Evans in 1902 (Fig. 95a). After his spring the man will fall on his feet behind the animal.

In the Athens Museum is a ring with an intaglio representing a gymnast who has just made one of these leaps (Fig. 95b), or else, holding on to the horns with one hand and resting on the neck of the animal with the other, he is letting himself be carried on. I Obstacles were also placed on the course in order to make the races more difficult, and here we see the branch of a tree laid on the ground. 2

When the animals were not racing the gymnasts performed other feats, such as that shown on the seal from Mycenæ (Fig. 97), or on the other from the Museum at Candia (Fig 98), described

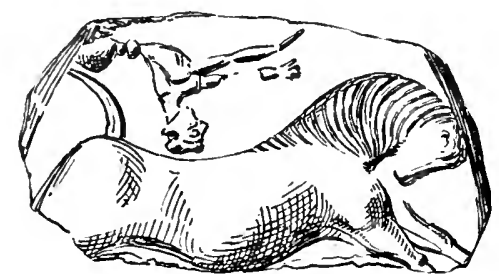

FIG. 95a.-BULL-GRAPPLING ON THE SEAL OF A BRACELET FOUND BY DR. EYANS.

by $\mathrm{Mr}$. Bosanquet, 3 who thought that it represented a bull surprised by a hunter. It is, however, a gymnast, who is holding on to the beast's horns with one hand while he extends his body in a gymnastic feat.

The tradition of similar performances has been carried on in Italy in the province of Viterbo, where untamed cattle are used, but instead of bulls, wild cows are brought in, and the public looks on in an enclosure, as in a bull fight.

The performers have a special costume with short breeches,

I Seals 956,97 and 98 are enlarged from plaster impressions.

2 I do not illustrate the other seals which show this position, and only quote Hogarth, "The Zakro Sealing," Fournal of Hellenic Studies, xxii. p. 86, Fig. 27. A fragment of dark greenish stone found on the Acropolis of Athens represents a man suspended in the air and a bull. The seal found at Hagia Triada by Professor Halbherr should perhaps be included among the bullgrappling scenes. I give the design (Fig. 96); the spoilt impression shows a nude woman in a gymnastic attitude behind a bull (Halbherr, "Resti dell' età micenea," Monumenti Antichi, vol. xiii. p. 44, 1903).

3 Bosanquet, "Excavations at Præsos I," Annual of the British School at Athens, No. viii. p. 252. 
and facing the furious animal, they take her by the horns and allow themselves to be carried on, turn aside the cow which tries to gore them with her horns, and spring upon her back or jump over her, while the crowd applauds.

\section{III.}

The horse did not exist in Crete in the Minoan period, and the horse being absent we can understand the development of gymnastic games with bulls, or the taurokathapsia, as the Greeks

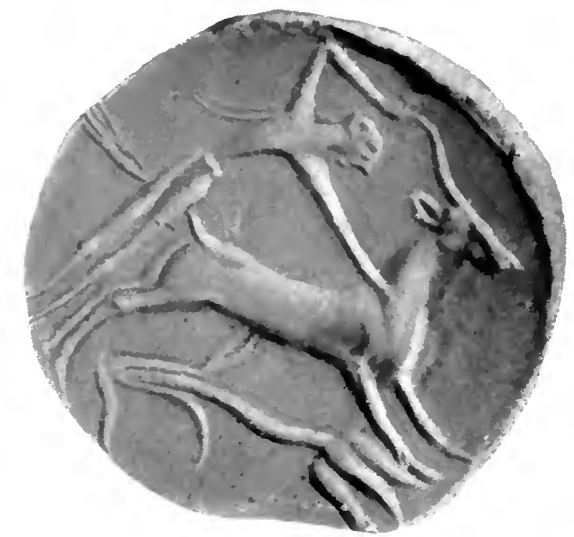

FIG. 95 b.-BULL-GRAPPLING ON THE INTAGLIO OF A RING IN THE MUSEUM AT ATHENS.

called it. In Fig. 98, a seal found in Crete, we see one of the gigantic bulls used in the taurokathapsia. The anatomy of this bull is worked out with great perfection, although it is an intaglio in hard stone.

The Italian Archæological Mission found at Hagia Triada the bones of the skull, with the frontal protuberances, of a bull. The horny material is destroyed and the bone which filled it is left.

This horn, 40 centimetres in length, measures 30 centimetres in circumference at the thickest part. Such horns are no longer 
seen in Crete, they belong to bos primigenius, which still exists in the Roman Campagna, in Umbria, in some Cantons of Switzerland, and in England. ${ }^{1}$

Economic conditions put an end to this breed; there were no great pastures, and the forest being destroyed, man found it more profitable to multiply the smaller beasts, which were cheaper and easier to feed. The oxen now seen in Crete have smaller horns than I have ever seen elsewhere.

Fig. $9^{8}$ shows some details of the kind of ground on which the games were held. Here it is certainly not the open field, but probably a paved court, with a footpath crossing the circus

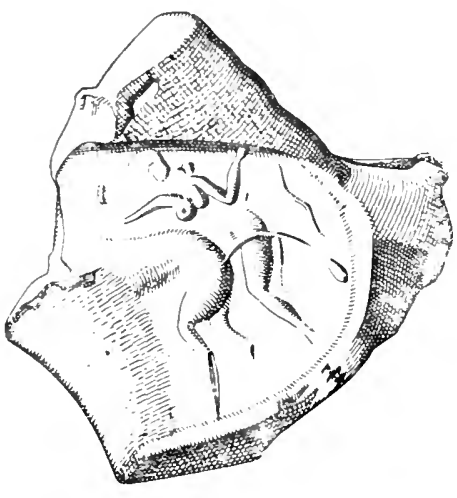

FIG. 96. - SEAL, FROM HAGIA TRIADA, ENLARGED. ground, like that in the theatre at Phæstos. Four sharp stakes were fixed in the ground as an obstacle, and a bar may possibly have been placed above it, so that the mountebank could leap over it while the bull passed beneath, as in a modern circus. One of the most ancient and hugest oxen known is that shown on Fig. 99, found in a tholos at Koumasa. It is from a terracotta vase, with the spout in the form of the head of a gigantic ox. Three men are holding on to the horns and letting themselves be carried along. The composition is better than the execution, and this is probably a copy of another vase.

One of the most wonderful frescoes discovered by Dr. Evans at Knossos represents a gigantic bull with a man leaping upon it, while two women are also performing a gymnastic feat. This discovery (made in I9OI) is interesting with regard to the physical education of women, and I alluded to it in a book of

I Gigantic oxen existed in Neolithic times, and in excavating at Phæstos I picked up vertebra, teeth, and bones beionging to a breed much larger than that now found in Crete. 
mine as soon as Dr. Evans had announced it in a preliminary communication. ${ }^{\text {I }}$

The rectangular picture is bordered by a design of great shells streaked and dotted with red, yellow, brown, and blue, more like marble than shells. In the middle is a man with his legs raised as if making a spring or being carried along by the bull to which he is holding. The beast is rushing on with his tail straight and his head low, while a woman, who has seized him by the horns, is letting herself be carried as she hangs on by her arms. Another woman stretches out

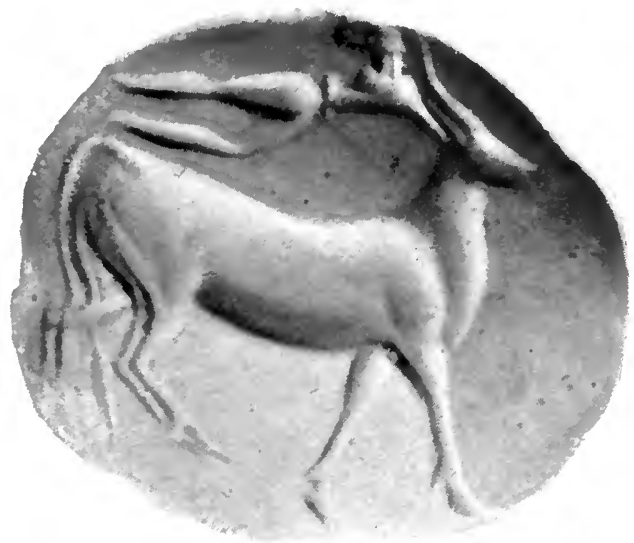

FIG. 97.- SEAL FROM MYCENA IN THE MLSELA AT ATHEAS.

her hands, possibly in the act of applauding, or perhaps to catch the gymnast when he has accomplished the somersault.

Both man and women wear boots, like the gymnast on the bull in the rhyton of Hagia Triada, who has also bracelets on his wrists. The women's bracelets are marked with a yellow line to indicate that they are of gold. They wear short drawers like those of our dancers; a yellow sash

I “Mens sana in corpore sano," p. 5, ii. chap. i. Awaiting the appearance of the exact reproduction which Dr. Evans is bringing out of this masterpicce I limit nyself to a simple mention of the great fresco, which is one of the ornaments of the Museum of Candia. 
embroidered I with red falls from the waistband in two folds before and behind. The bull has great yellow patches, chiefly on the back and neck.

The opposite wall was decorated by a similar picture, for among the fragments of stucco the shoulder and arm of a woman who is holding a bull by the horns are visible. There

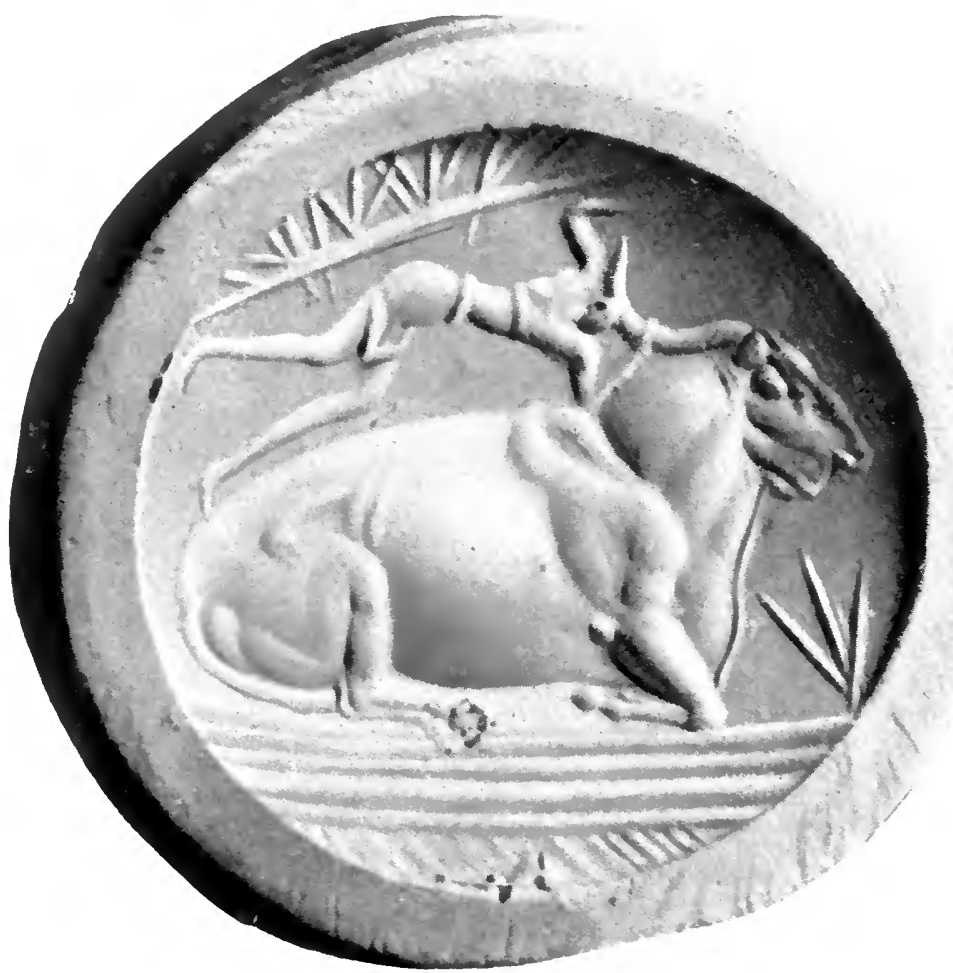

FIG. 98. - SEAL FOUND AT PRASOS BY MR. BOSANQCET, IN THE MUSEUM AT CANDIA.

is also another woman like these, with black, waved tresses. A man with long, floating hair has a band round his forehead. The background of these pictures, of which fragments have been found, varies. One woman is on a blue ground

This costume is very similar to that of the wrestlers and gymnasts on the steatite vase, and the soldiers' dress differs little from it. 
and the other on a yellow ground, with fragments of a grey bull.

Fig. I00 shows fragments of a fresco discovered at 'Iiryns some years ago, and now in the Museum at Athens. Dr. Dörpfeld, who published it, thought that it represented a bull hunt, and that the artist, through ignorance of perspective, had drawn the hunter above the bull. After what I have just explained there is no doubt that this fresco represents a

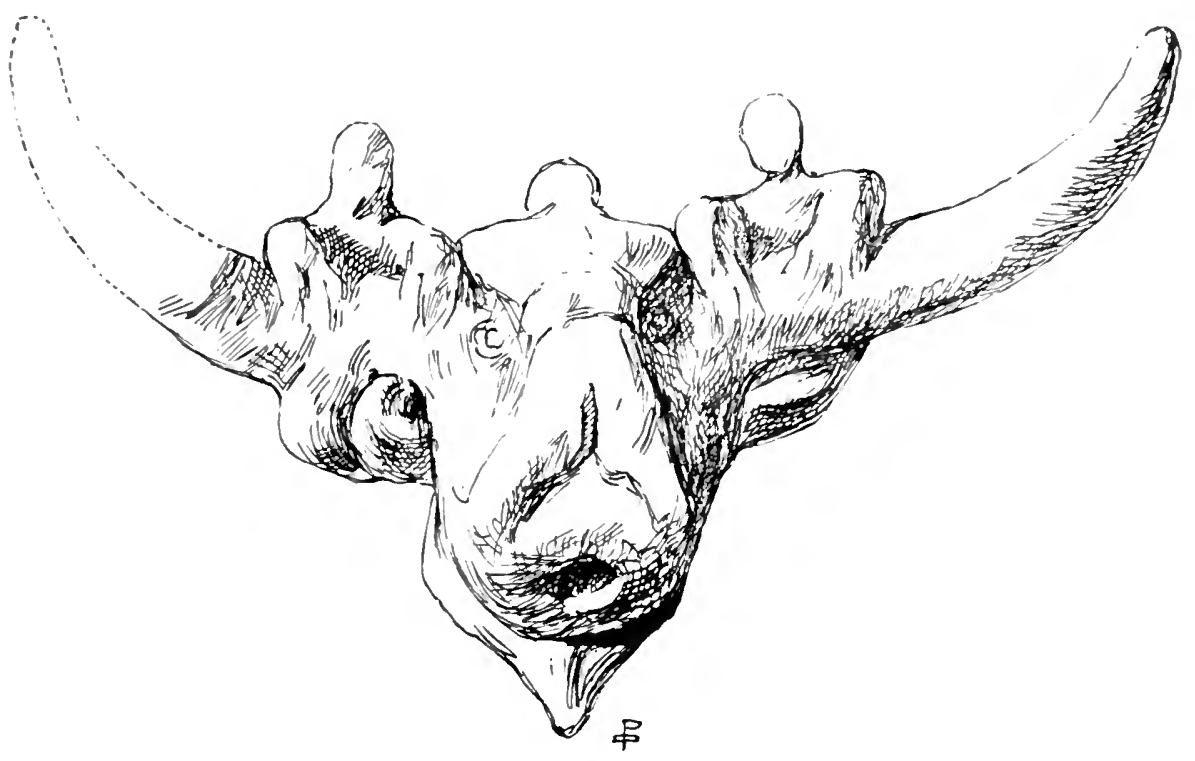

FIG. 99.-HEAD OF A GREAT BLLL, WHICH FORMLD THE SPOLT OF A TERRACOTTA VASE FOL'ND AT KOLMASA.

taurokathapsia, and that here too the performer is a woman, for the skin is white; if it had been a man he would have been painted red.

\section{IV.}

The most magnificent records of the taurokathapsia are the stucco figures in half relief and the ivory statuettes found by Dr. Evans at Knossos. Though there are only a few fragments of the stucco, they give so lifelike an image of the bull that 
it is equal, if not superior, to the Farnese bull in the Naples Museum, which breathes a suggestion of false art. The head in particular is a fragment of great value, for the details of the mouth, eyes, and nostrils, which are full of expression. Upon the bull stood a man, and the modelling of the veins and the standing out of the muscles is perfect.

Dr. Evans has explained an arm holding a horn (Fig. IOI) as the arm of a man carrying a vase. This was a sudden idea after Dr. Evans had discovered one of the finest

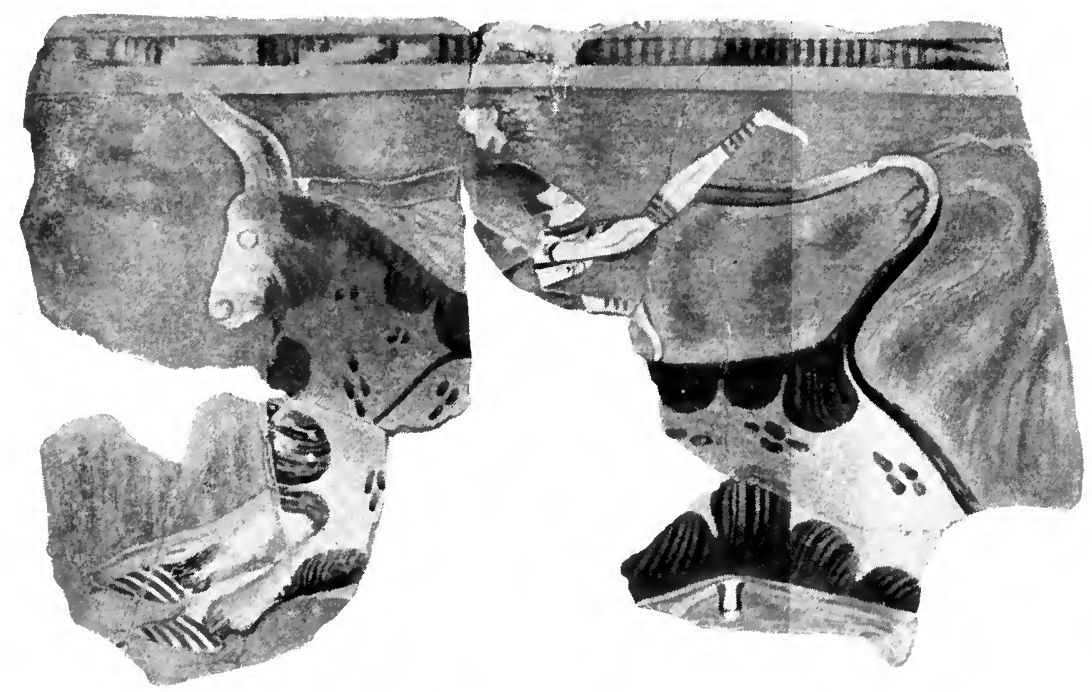

FIG. IOO.-FRESCO FRON TIRYNS, IN THE MUSEUM AT ATHENS.

frescoes of Mycenæan art, representing a youth carrying a conical vase.

My recent studies oblige me to give a different interpretation to this relief. The measurements which I took of a bull's horn at Hagia Triada enable me to compare it with the dimensions of this arm, and they agree. Also the slight curve of the object, which is quite different from the rectilinear outline of a conical vase, shows that it is a horn. So strong a contraction of the muscles of the forearm as the artist has rendered here would not be necessary if it were simply a case of carrying a vase. The 
way in which the hand is clenched show's also that it is a case of a gymnastic feat ; a horn is slightly curved at the tip, and for that reason it is better to hold on with the hand tightly closed, but this action does not agree with the manner of carrying a conical vase, which would require to rest in the hollow of the hand in order to be kept in a vertical position.

These stuccoes were found in a part of the palace which was decorated with great magnificence and adorned with columns, and where the walls were ornamented with paintings in fresco and spiraliform designs in blue and black on a white ground. I

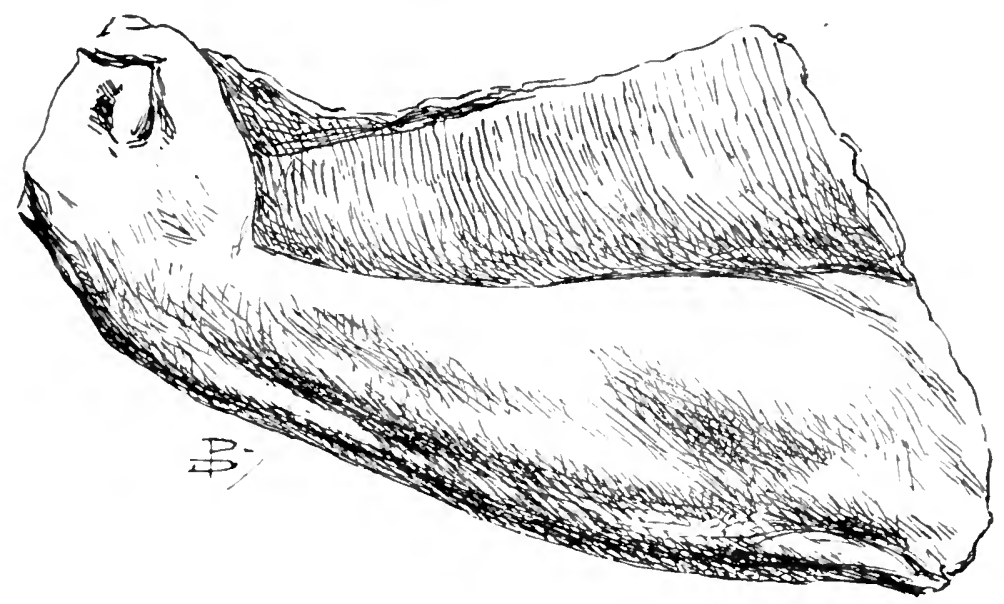

FIG. IOI.-FRAGMENT IN STUCCO FOLND AT KNOSSOS BY DR. EVANS.

Probably part of a taurokathapsia.

I use the word "stucco" because the term "gesso duro" used by Dr. Evans is incorrect. In fact when I made a chemical analysis I found no trace of sulphate of lime, which proves that it is not gesso; on the contrary, it is entirely carbonate of lime. Probably lime and marble dust were used for these reliefs. In Vasari's "Lives of the Painters," chapter vi., "Architecture," he says that

r "The Palace of Knossos," Anmual of the British School at Attens, No. vii., p. $87,1900-190 \mathrm{r}$. The calf of the left leg, the right shoulder with the forearm, life-sized, were found also. Fragments of another taurokathapsia in stucco were found near the north door. The fragments consist of a man's leg, two hoofs of an ox, the tip of a horn, and the tips of two tails. 
stucco is a paste made of pounded marble and lime of travertine. Work carried out in simple gesso would be less firm and less enduring.

\section{V.}

Masterpieces of Mycenæan art are the ivory statuettes found by Dr. Evans (Fig. IO2), which he says represent men either about to dive or about to spring into the air. One of these statuettes probably represents a womian. The ivory was found to be so friable that the fragments had to be placed in melted wax in order to bind them, lest they should fall to powder. ${ }^{\mathrm{I}}$ The hair was made with curls of bronze wire inserted into the skull, and the garments of gold leaf.

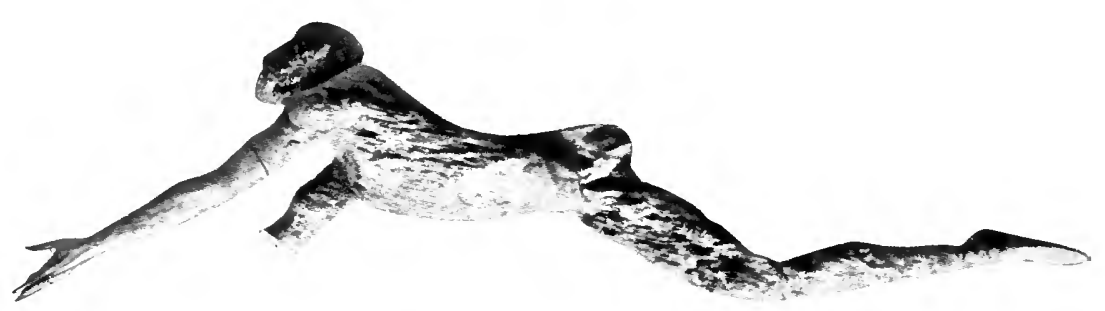

FIG. IO2.-IVORY FIGURE FOUND AT KNOSSOS BI DR. EVANS.

The life in these statuettes, the spring and the natural manner in which the arms and legs are extended, fill us with wonder. In these ivory figures and the reliefs in stucco Mycenæan art was at its culminating point. The veins of the hands, the details of the nails, the folds of the skin at the joints, were all exactly reproduced. There are bracelets on the wrists, and from the evidence of some of the fragments I am persuaded that there were some female figures among those of men, as we see in the fresco at Knossos. 3

It is to be hoped that further excavations may bring to light fragments of the bulls; the similarity of the attitudes of these figures to the fresco at Tiryns and to the seals which I have

I “Knossos Excavations, I902," p. $72 . \quad 2$ Length 29 centimetres.

3 There must have been two more of these figures, for there are three ivory arms and three legs to match. 
described is too great to leave room for doubt that they belong to a taurokathapsia. The theory of acrobatic performances with bulls explains the attitude of these figures. The head is bent backwards, and this would be dangerous in a man who was about to dive into the water; while this position would be quite suitable in a performance on the back of a bull.

The proportions (or, one would say, the canon) show the slender athletic type which predominates in the seals and frescoes. I will spare the reader a digression on the female type in Mycenæan art, but I cannot omit the fact that women are here represented of equal height with the men, as in England and America of to-day.

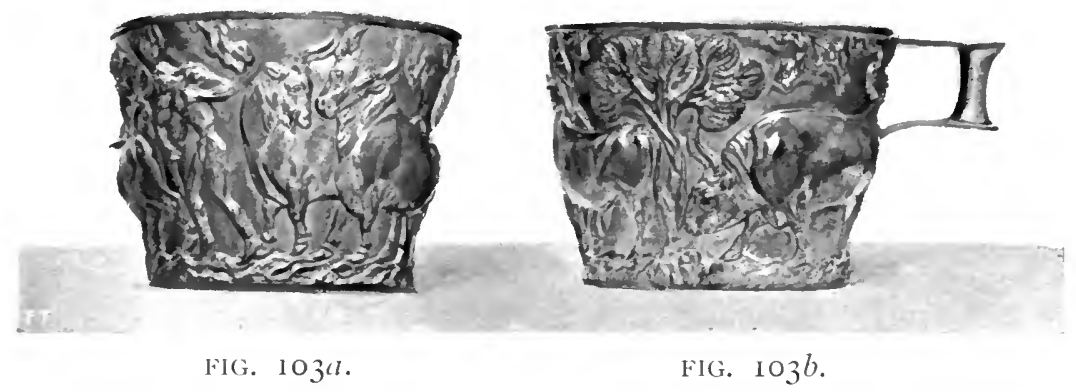

(GOLD CLP FRON VAPHIO, IN THE MLSECM AT ATHENS.

Dr. Evans thought that these statuettes had been hung up by a gold thread or chain, as was done later by the Greeks with the amorini, but after the explanation and comparisons which I had the pleasure of placing before him, he is now convinced that they are connected with bull-grappling, which indeed he had already suggested in his writings.

\section{YI.}

The two celebrated cups from Vaphio discovered in a beehive tomb near Sparta I in I 889 belong to this group of bull-

I Tsountas and Manatt, "The Mycenæan Age," p. 22\%. The description of the tomb and cups of Vaphio is also in Perrot and Chipiez" work, "Histoire de l'Art. La Grèce primitive," pp. $+08,-88$. 
grappling subjects, and are of gold with double casing. In the first (Fig. 103) a man is binding the legs of a bull with a rope. The garments, hats, and shoes are identical with those of the gymmast on the vase from Hagia Triada. Two other bulls stand near and are licking each other, another is quietly grazing. This scene shows that the bulls are not wild. The artist has got beyond the ancient school, which only drew in profile, and has drawn a bull's head full face. Two trees and fragments of rock fill up the background. A contrast to this quiet pastoral scene is that on the second cup (Fig. IO4), a picture full of life and movement with struggling and rushing cattle. ${ }^{I}$ The person holding on to the bull's head is a woman (Fig. 104c), as may be

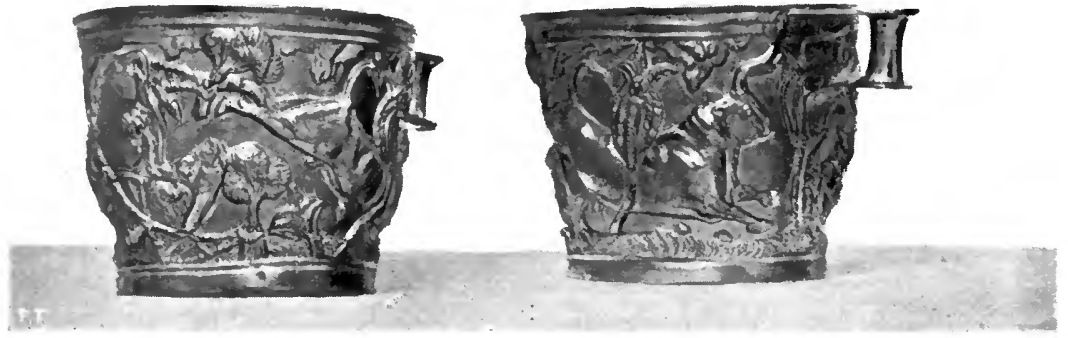

FIG. IO

FIG, IO ${ }^{h}$.

GOLD CLP FRON VAIHIO, IN THE MLSEL'M AT ATHENS.

seen if the figure be observed with attention. The other is a man, and both are dressed in the same fashion as the gymnasts of Crete.

Tsountas and others who have spoken of this cup think that it represents a hunting scene with wild bulls, and that the furious animal, after throwing down one of the hunters, has caught up the other on his horns. Against this explanation is the fact that the two persons struggling with the bull have nothing in their hands to lasso him with. If the bull had transfixed the hunter with his horns, the latter would have had her head up and not downward.

I I asked M. Gillieron, the artist (who is the most competent in Mycenzan art), to make me a drawing of the part which represents the taurokathapsia, and I am gratetul to him for doing me this favour. 
No doctor can allow that this woman is wounded, for she is holding on with her knee bent over one horn and her shoulder resting against the other. We must, therefore, admit that it is a woman in an acrobatic game, like that on the rhyton of Hagia Triada.

The net was not used in hunting wild bulls, and the fashion in which it is stretched shows this, for being short the animal would have turned round in it; it is an obstacle such as are used in racing in comnection with hedges and fences. The fallen man has been standing on the bull which is entangled in the net; the bull with the gymnast on his back was to have leaped over it but has failed, and the acrobat has fallen on his head.

The similarity of the details, shown by a comparison with the reliefs and frescoes of Crete, compels us to admit that the cup of Vaphio also represents a taurokathapsia, and I would take a step further and conclude (judging by the greater number of representations of this subject found in Crete), that here was the most advanced school of painters and sculptors.

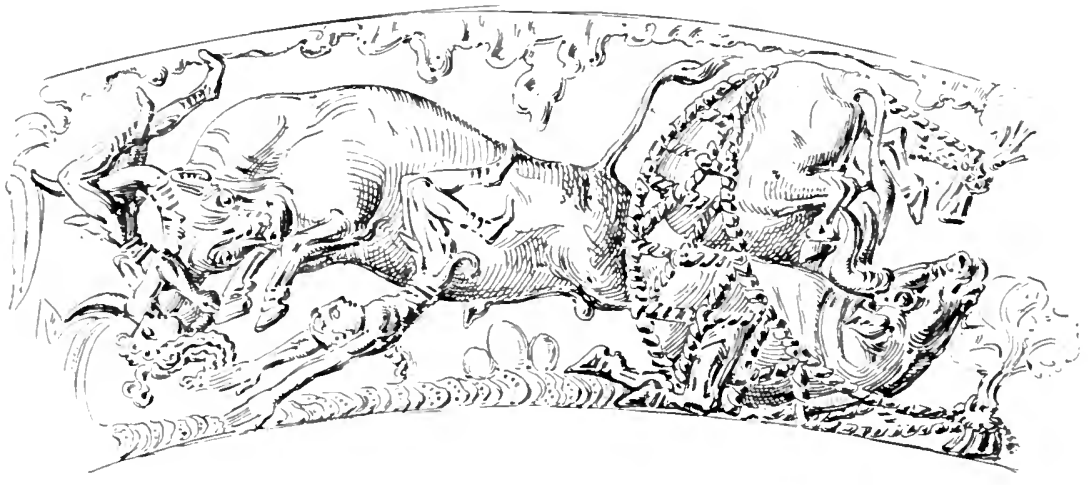

FIG. IOfC-DETAL OF THE NAPHO CLP, TWO-THIRIS OF THE ACTCAL SIZL. 


\section{CHAPTER XII}

FOOTGEAR IN THE TIME OF MINOS

I.

"Telemachus bound on fine soles beneath his tender feet." I

THE Homeric poems only allude to soles or sandals ( $\pi$ ćcida) When Odysseus returns home he finds the old servant Eumæus making sandals, "cutting a well seasoned ox-hide." 2

Nearly every form of footgear worn at the present day existed in Crete, and we are sure they were in use more than a thousand years before the Homeric poems were composed. It will not be unprofitable to turn our attention to this subject, for we shall find fresh proof that the heroic poems give us a very incomplete idea of the life of pre-Hellenic man.

Besides soles, Homer also names gaiters. When Odysseus, in the last book of the Odyssey, visits old Laertes in the garden : "Alone he finds his father, stooping and digging round a plant. A soiled and mended tunic covers him, and greaves of patched leather protect his legs from the sharp pricks of thorns, and gloves his hands."

The great variety of Mycenaan footgear has already been shown in the illustrations of the preceding chapters. The officer of the Hagia Triada vase (Fig. 33) wears the puttees of an Alpine climber or an English officer; from the ankle to half way up the leg (Fig. I05) there are five turns of a bandage-

$$
{ }^{1} \text { Odysey, xu. } 2 \text { Ibid., xiv. }
$$


not the creases which are seen on the leg of a riding boot, but really a bandage tightly folded round the leg (Fig. 33), with the end turned obliquely as if passed below the next fold. The details of this gaiter are better seen in Fig. I06, taken from the steatite vase found at Hagia Triada. This is slightly enlarged from the last figure to the right in the uppermost zone. The sole appears to be marked, and the quarter is cut in a triangular shape from the heel to near the toes. One strip binds the sole to the instep, and the rest of the bandage makes four turns above the ankle. The soldier in

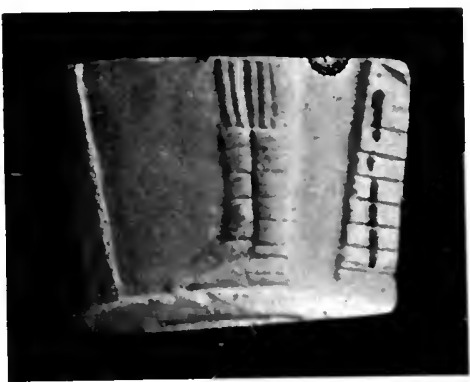

FIG. I05.-FOOTGLAR OF AN OFFICER.

Fig. 34 wears boots. This form of footgear is often found on military statues cast in bronze, and on one terracotta published by $\mathrm{Mr}$. Dawkins. ${ }^{\mathrm{I}}$ A bronze statue similar to this was found at Rethymo, and both are important on account of the shape of the dagger worn at the belt by these soldiers; it is one of the most ancient forms of

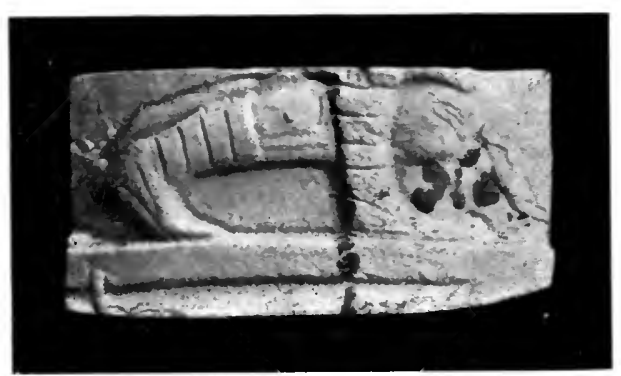

FIG. IO6.-FOOTGEAR OF A GIMNAST. weapon known, and the blade even is of copper. Daggers similar to these, not only in shape and length of blade, but also in the form of the hilt and the two bosses seen on the hilt in Fig. Ios, were found in their place near a copper knife which lay on the thorax of a skeleton in the Necropolis of Remedello in the district of Brescia. ${ }^{2}$ The boots of this soldier are white,

I B.S.A., vol, ix., I 902 .

"Colini, "Il Sepolcreto di Remedello," Bullet. Palet. It. anno xxir., I 898 , pl. ix. p. 24 . 
and are of the same shape, and probably made of the same kind of leather as those worn in Crete at the present day. The leg of the boot was made in various shapes, as we may see if we compare the boots of Dawkins's figure with the narrower topboots of the conscript in Fig. I07. If we look closely at the part near the great toe in the original, we can see an opening, as if the artist had intended to represent a poor conscript who had hastened to take up his service with broken boots. It is certain that two forms of footgear were in use among soldiers - boots, and shoes with tight bandages on the leg.

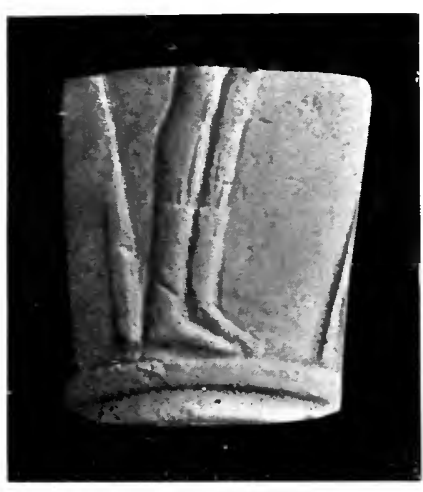

FlG. 107.-BOOTS OF A SOLDIER.

II.

In the Cyclopæan house at Mycenæ, which was probably the dwelling of the princes, Dr. Schliemann I found some good terracottas, and among them a vase with a design of six soldiers who wear gaiters like those of Napoleon's grenadiers. I reproduce a portion only of this vase (Fig. I09), the remainder of the figures being all the same. These soldiers are painted in dark red on a yellow ground. On the left shoulder they carry a circular shield, cut out below in a crescent shape. They have the helmet and lance, and their legs are protected by simple gaiters.

The upper part of the gaiters is fixed by a bandage passing two or three times above the knee, which proves, according to Schliemann, that these gaiters are of stuff. The feet are shod with sandals, which seem to be fastened by straps passing over the ankles where the gaiters begin. It is not a question of greaves, which, as we know, were made of metal plates shaped to the leg and fastened by leather straps. When Achilles armed himself to avenge the death of Patroklos, "he fastened on his

$$
\text { s Schliemann, "Mykenæ," } 1878 \text {, p. } 153 .
$$




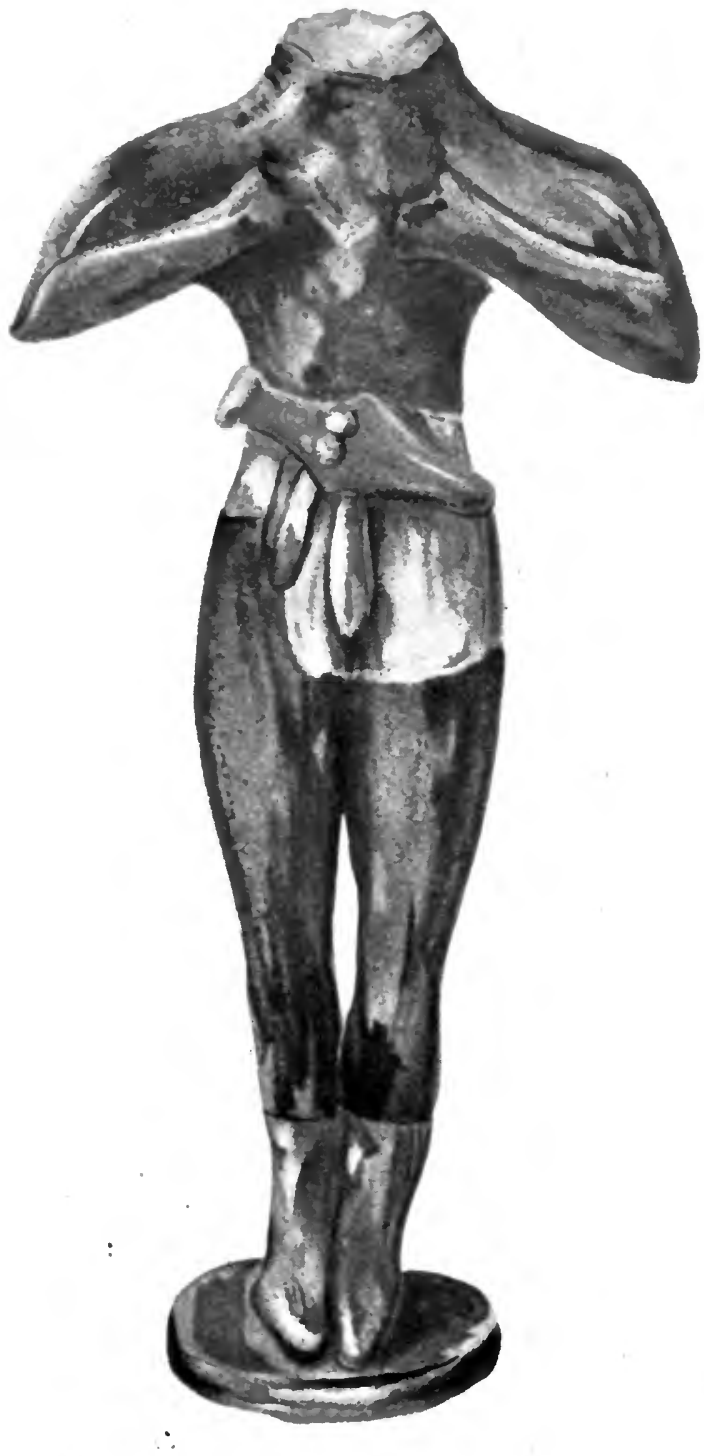

FIG. IOS. -TERRACOTTA FIGLRE FOUNI) AT PE TSOFA, NEAR PALAKASTRO, BY MR. DAIKINS. 

legs the fine greaves with silver buckles." I By a strange fancy of the poet the greaves of Achilles were of tin. When Agenor assailed Achilles he "cast with vigorous hand his spear, and caught him on the shin below the knee, the tin of the uninjured greave resounded, but the sharp steel rebounded from the divinely" tempered metal without piercing it."

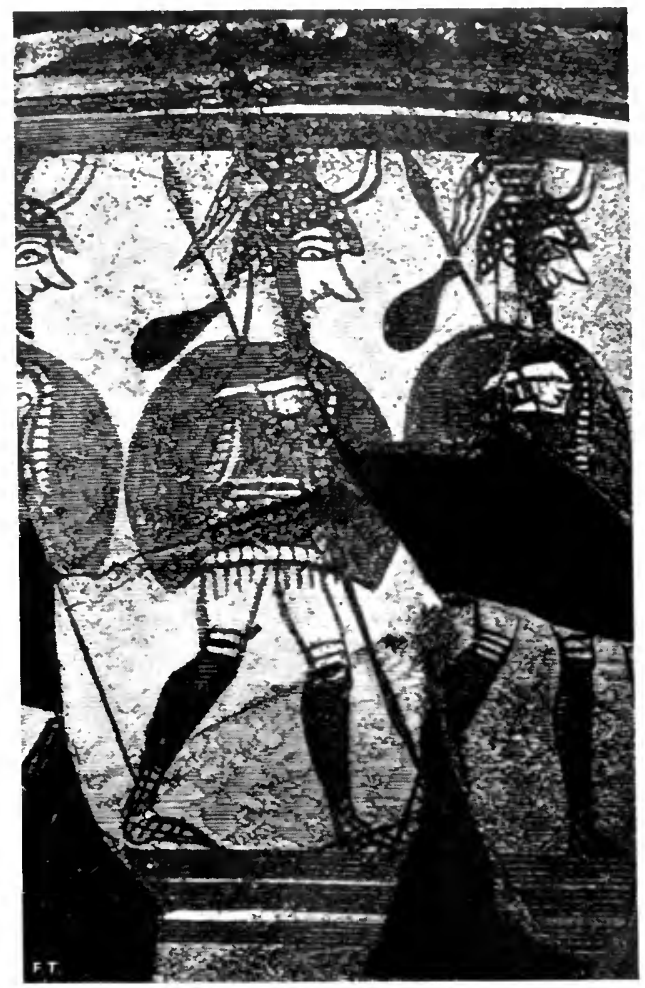

HIG. IOQ.-PART OF A VASE FOUND AT MYCENAE BY DR. SCHLIEMANX (ABOCT ONE-THIRI) OF THE ACTUAL SIZE).

Let us consider some discrepancies between poetry and reality. Tin does not resound when it is struck, and it is soft enough to be cut by a hard thrust from a spear. We might suppose that the greaves of Achilles may have been of tinned copper. In fact Helbig records that portions of copper belts, with traces of

$$
\text { I lliad, xix. }
$$


timning, have been found in the tombs of Samnium. ${ }^{\mathrm{I}}$ But this is not the case here, for we read in book xviii. of the Iliad that when Hephaistos forged the armour of Achilles the last piece of work was the making of the greaves of pliant tin. These incongruities help us to trace the history of metal work. The singers of the Homeric lays were probably not well acquainted with the making of bronze, for weapons were imported, and the makers did not explain how they were made. Hephaistos himself did not know the secret when he prepared the bronze to make the arms of Achilles. Together into the fire he cast silver and precious gold and tin and invincible copper, ${ }^{2}$ and within the crucible a score of bellows blew. This mixture of four metals fused together is a poetical invention, of which archæology has found no trace. 'I 'The ancients melted gold and silver together to form electron, but no objects of bronze containing both gold and silver have been found.

Helbig thought that the poets were not acquainted with tin, and that it was only named here as a rare metal to heighten the charm of the story. 3

\section{III.}

Shoes like our own were worn at the time of Minos. I reproduce a model discovered at Sitia, in the far eastern part of Crete, by the British School (Fig. I IO). The shoe is so well modelled that this alone would suffice to prove the great skill of the Minoan sculptors. It is made for the right foot, and this fact shows that the Cretans were shod with taste, and liked wellfitting shoes. They have no heel, and shoes without heels are still worn in Crete.

The fancy for elegant footgear was common to the peoples of the Egean in the Minoan age, as the last paragraph of this chapter will show. Even in Homeric times the epithet "well shod" was applied to the Greeks on account of their choice footgear. In spite of this, however, at the time when Greek

I Helbig, "Das Homerische Epos," p. 286.

2 Iliad, xviii. $\quad 3$ Helbig, loc. cit. p. 285. 
sculpture reached its highest point of perfection, Greek artists either represented their statues with sandals, or with shoes of far less elegance than those of the Minoan age. The famous stelai which are now admired in the Museum of Athens were found in the Street of 'Tombs in Athens. I reproduce the stele of the wife of Proxenos (Fig. I I I). She is seated within the profile of a small temple, with her name, Egeso, inscribed upon the architrave, and is looking at a jewel which she has taken from a casket that her handmaid is holding before her. This piece of sculpture dates from the latter part of the fifth century B.c., and shows to what marvellous perfection art had attained in the time of Pheidias, when such a piece of work as this was made to order without even being signed by the artist. The handmaid wears shoes, and the mistress has sandals on her feet. The artist has not indicated the buckle or strip of leather which must have fastened on the sole, and this sandal could not be used as it is here shown, for the sole would not

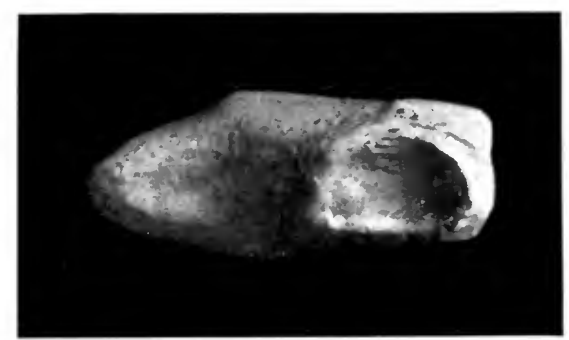

FIG. IIO.-TERRACOTTA SHOE FO(NI) A'T SITIA BY THE IBRITISH SCHOOL. keep in place beneath the foot in walking. The artist has made another distinction between mistress and maid-the maid's nose is not drawn in a line with the forehead, but forms an angle at the point of junction. As there was a classical nose with the projecting forehead which gave a more beautiful profile, and was distinct from the common type of face in which the line of the nose forms an angle at the junction with the forehead, so there was also a classical Greek form of foot with the second toe longer than the first, as seen in this stele. This form of foot is very rare in modern Greece, as with us, and the usual shape of foot has the great toe longer than the rest. Sculptors, however, do not admire this foot with the outline of the toes slanting off, and prefer the classical type of the antique statues which is rarely found in a model. The foot is only 
beautiful in early childhood, for then the great toe is slightly detached from the rest, as in ancient statues; later on the foot is deformed by wearing shoes. Shoes have certainly deprived us of the asthetic pleasure of the sight of this part of the person. If we think of the beauty of the hands, the grace of their attitudes, the harmony of their outline, the inexhaustible poetry which proceeds from beautiful hands, we must allow that sandals were more artistic, though less convenient for winter and rainy weather than shoes. We no longer see the beautiful feet of silver which are so often alluded to in the Homeric poems, and we have lost, too, many other elements which formed sources of inspiration for the poets. The finest of shoes or stockings cannot equal the beauty of the bare foot, and the contemplation of the toes helps the artist eye to receive a more perfect impression of the beauty of the human body.

Helen, who was rendered terrible by the diabolical influence of her perfect beauty, recognises Telemachus as the son of Odysseus by his feet, and the Homeric poems praise, too, the beauty of the ankles of Menelaus, her husband. These allusions show how niuch better versed than ourselves in the knowledge of beauty was the Hellenic race, and how through the wearing of shoes we can no longer appreciate certain points of anatomical perfection. The beauty of a foot lies in a high instep, and when this part, on which the leg rests as upon an arch, is raised, the flexus, or empty space beneath the foot, between the heel and the toe part, becomes more arched. The foot is defective when the heel projects too much, so as to form a curved outline with the line of the ankle.

IV.

Shoes with heels were worn by the Mycenæan women (Fig. I I 2). The shortness of the hair and the hasty engraving of the bust in these figures would leave us in doubt as to their sex were it not that the fashion of their skirts shows that they are certainly women. The illustration is from a ring from Mycenæ, magnified three and a half times. There is nothing, 


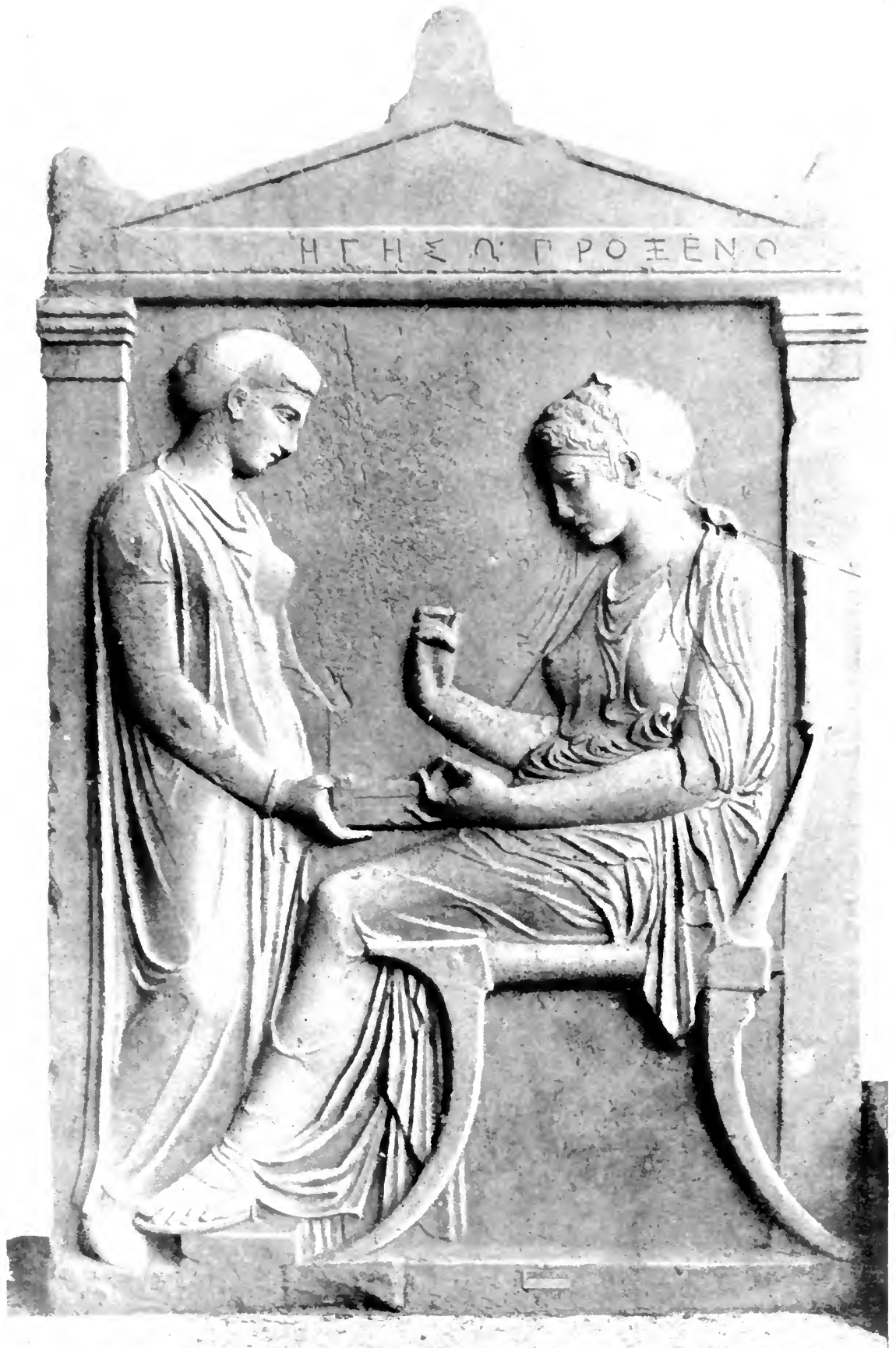

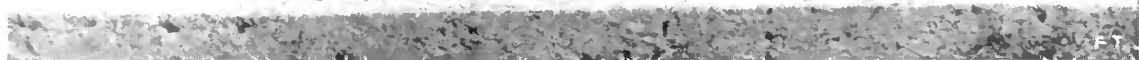

FIG. II - STELE OF EGESO, WHE OF PROXENOS, IN THE MLSECM AT ATHEAS. 

therefore, in modern footgear which was not in use in Mycenaan times.

I will now try to make use of this dull discussion on shoes by comparing the Isle of Crete with Greece, and showing thereby that civilisation and the diffusion of art moved from the south northwards, and not from Europe towards Africa.

The footgear of the three persons standing among the bulls on the Vaphio cups is identical with that of the officer in the Hagia Triadit vase (Fig. 33), and with that of the gymnast on

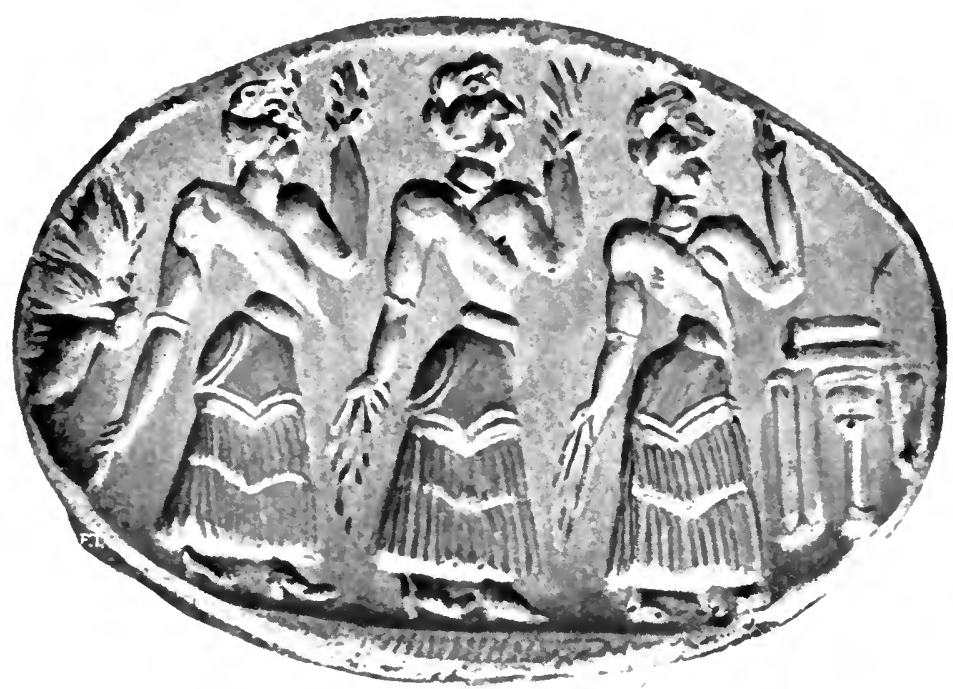

FIG. I 2.- SEAL FROM MYCEXA, MAGNFIEI) 3: TIMES.

the conical vase of steatite which was also found at Hagia Triada (Fig. 93), and to show this more clearly I give a slightly magnified illustration (Fig. I I3) of the leg of the man who in Fig. IO+ is touching the ground with his hand as he falls. This form of footgear appears to have been generally worn by soldiers and gymnasts, and on a seal ring from Vaphio ${ }^{I}$ is a man wearing shoes exactly like those of Fig. I I 3 .

It is important to notice not only that the same forms of

I A. Evans, "Mycenæan Tree and Pillar Cult," Fourmal of Hellemic Studies, xxi. p. $1 ; 6$ 
shoe were worn in countries so far apart, but also that the footgear of the gymnasts on the conical vase from Hagia Triada is the same as that of the persons upon the bulls of the Vaphio cups, thus proving, if further proof is wanted, that the persons here represented are really gymnasts, and not men occupied in hunting bulls. The identity of the footgear in the Isle of Crete and on the continent establishes another connection with these cups, which are marvellous as works of art even among the other productions of the Cretan school. The great variety of footgear found on the Cretan monuments is not accidental, but is repeated on the pottery, on the palace frescoes, on the statues,

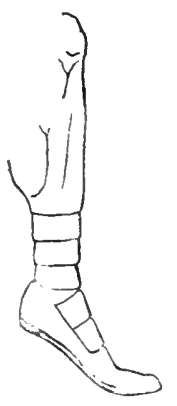

F1G. $113 .-$ FOOTGEAR OF $\triangle \mathrm{GYN}$ NAST ON $A$ CLP FRON VAPH 10 . and in every form of plastic art, so that we must conclude that Crete was the cradle of Mycenæan art.

In the great fresco discovered at Knossos by Dr. Evans the women standing one before and one behind a gigantic bull, upon which a man is turning a somersault, are again differently shod from the figures we have discussed. The woman who is being carried on, hanging to the bull's horns, is wearing boots like the elastic-sided ones of the present day. To hold the boots well on the foot there were strings, which possibly passed through eyelet-holes, but in the case of the woman who is hanging on to the horns these strings are seen on the inner and outer side of the boots like our elastics, while the woman who is standing with outstretched arms behind the bull only appears to have a black triangle with the base downward, probably formed by the laces on the outer side of the shoe. The man has on a pair of white boots which come only a little above the ankle, and we do not see how they are laced. In some of the ivory statuettes of the bull-grappling figures (Fig. 98), the toes are not marked on the feet, although the hands are finished with scrupulous accuracy. This makes me think that socks with a thick sole were worn by the gymnasts to prevent them from hurting their feet on the ground 
or stones, and possibly also to give them a roughened sole to enable them to avoid slipping on the smooth hide of the beasts. Fig. 63 gives us reason to think that the women wore stockings, for the painter has here so carefully indicated the details of the embroidery that he would have been sure to nark the toes with a touch of the brush if they had been visible.

\section{I.}

In the Mycenxan palaces we notice the corrosion of the stairs which are in the open air; the damage to the steps of the northern staircase of the court I of the palace of Knossos was very noticeable, but the indoor stairs and all the pavements, even those with red colouring in the cement, were in perfect preservation. This fact suggests two things: first, that great care was taken of the pavements; and next, that it was usual to walk barefoot in the house. The general custom in the Homeric poems of putting on sandals only on leaving the house or ship has been kept up in the Last, where Mohammedans take off their shoes before entering a mosque. At the beginning of the Odyssey thene wears golden sandals, which bear her over the sea like the wind. Famous among Greek statues is the Victory of the Acropolis of Athens unlacing her sandals (Fig. I I 4 ). Ihe pose with the head between the folded wings, the beautiful forms of the nude and the grand drapery mark in this lowly action the highest perfection of art.

On the left of plate i., the plan of the palace of Knossos, is the southern entrance, with a corridor 3 metres 30 centimetres wide, the pavement of which had a strip of limestone down the centre, while the edges up to the walls were of blue slate. On the left side was a series of life-sized figures representing a procession, but, unfortunately, only the feet and the lower part of the garments have been preserved. 'To the north was a fresco in which were four figures with very magnificent long robes. We know that

"A. Fvans, "The Palace of Knossos," Annual of the British School at Attem, vi., I $899-1900$. 
they are men because the feet are painted in a reddish shade. Opposite is a woman with white feet, wearing a flounced skirt, and, at a little distance there is another woman, probably a queen, wearing richly embroidered garments. She is followed by three children and three men.

Though these fragments show little more than a procession of bare feet with a magnificent decoration on the edges of the dresses, they produce an ineffaceable impression. I)r. Evans considers that this fresco represents an embassy bringing tribute to the sovereign of Knossos. One of the best preserved figures was found here - a youth carrying a conical vase of marble with the base of silver.

\section{VI.}

At the beginning of the fourth book of the Iliad we are told

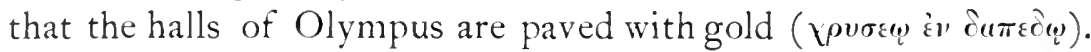
In the Bible, too, we find, in the description of Solomon's Temple, "and the floor of the house he overlaid with gold within and without." I 'The Mycenæans knew how to gild bronze, and probably fastened thin plates of gold upon marble with albumen, as Pliny tells us, ${ }^{2}$ but as we find no trace of such gilding on the pavements we may suppose these statements to be poetic exaggerations. In any case it is strange that beside these pavements of gold, floors of beaten earth, such as would not be found in any palace of the Minoan age, should exist in the royal residence of Odysseus. This discrepancy between the pavements discovered by Dr. Schliemann at Tiryns and Mycenæ and those described in the Homeric poems had already been noticed by Helbig. 3

When Penelope, at the suggestion of Athene, proposes to marry the suitor who can bend the bow of Odysseus and shoot an arrow through the iron rings, Telemachus makes the preparations: he "put off the purple mantle from his shoulders and laid aside

\footnotetext{
I I King vi. 30.

3 Helbig, "Das Homerische Epos," p II
} 


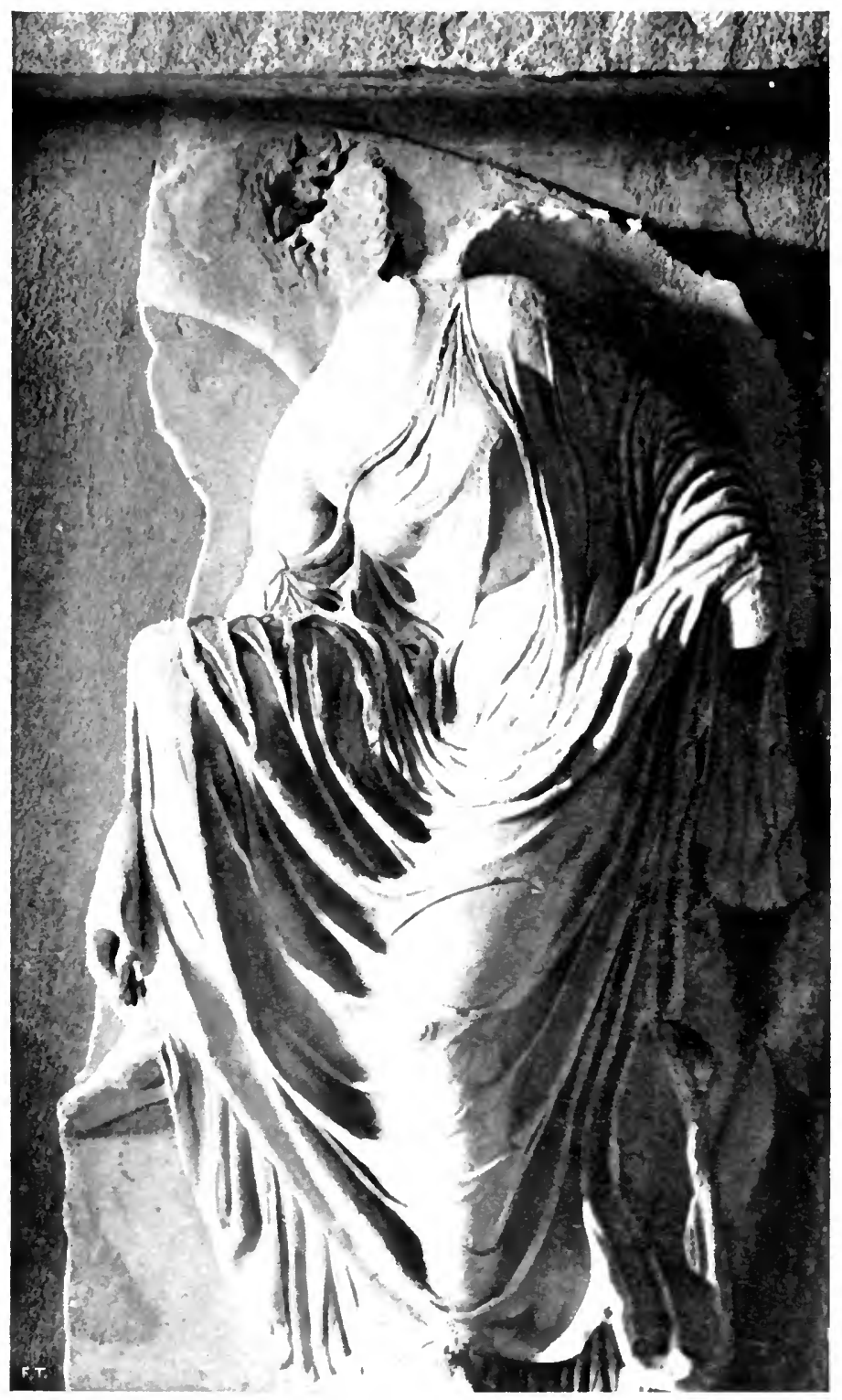

FIG. I +. -VICTORY OF THE AClOPOLIS OF ATHENS LNIACING HER SANDALS. 

the sharp sword, and dug first a long trench, then planted there the stakes with rings at the top, fixed in a straight line, and stamped down the earth." I

We have other indications that the earth floor in the palace of Odysseus was not very solidly laid. I found this year in Sicily that even in the Neolithic period there were huts with better floors than those of the reception halls of the kings of Ithaca. In fact I discovered at Caldare a double laid floor like that in the palace of Tiryns: the lower floor was roughly laid, and the upper one, also of clay and scarcely a centimetre thick, had been beaten hard and then slightly baked by being covered with fire. This pavement was so hard that I was able to carry a large piece to the Museun at Syracuse. This example of the pavements of the Neolithic age in Sicily is sufficient proof that civilisation could not have receded so far in Homeric times as would appear. The poets themselves must have imagined this semi-barbarous state of the Hellenic peoples of the heroic age.

Some of the pavements at Tiryns, described by Dr. Dorpfeld, are decorated with geometrical designs, and are too hard to agree with the Homeric accounts. Dr. Dörpfeld speaks of some which have a border of red and black, and others with white and yellow squares. We can hardly think that the poets did not know of this degree of luxury, and that the traditions of Tiryns and Mycenx, of Knossos and Phæstos, should have been completely lost.

The pavements in the Cretan palaces were so carefully made and finished and are to this day so well preserved that we may suppose that they did not require to be covered by carpets. These were only used for laying on the beds and seats. No wooden floors were found in the palaces of Crete and for this reason socks would probably be worn in the winter, for when there was snow on the ground it could not be very pleasant to walk barefoot on alabaster, cement, or marble. Skins may have been used for walking on. When Telemachus arrived at Pylos the king received them courteously, "took them by the hand, 
and where the sand was carpeted with soft fleeces made them sit near the table." I

VII.

In an Egyptian tomb of the XVIIIth Dynasty we find proof that elegant footgear was a characteristic of the Cretans in the Minoan age. This tomb has a sculptured decoration representing the deeds of a prince who was governor of Egypt while his king, Thotmes III., was occupied by wars and conquests at a distance from Thebes. This governor, Rekhmara, is represented listening to the reports of his officials or giving audience and judging cases, superintending the work of the artists, organising the distribution of food to the prisoners - in fact, the whole administrative life of this viceroy of Pharaoh is shown in sculptured scenes covering a surface of 400 square metres. On the opposite walls are represented the funerals and ceremonies, feasts and song and the dances in his honour, and all the particulars of his existence beyond the tomb. More interesting to us than even the details of the private life of this governor, whom we see in his rare hours of leisure at banquets, in the midst of women, flowers, and music, are the scenes representing the peoples protected by the Pharaohs bringing tribute to the king. In one picture the Somali bring presents of purely African originbaskets of ostrich eggs, gum, perfumes, leopard skins, elephants' tusks, ebony, monkeys, and ostrich feathers. Next come the Cretans. This scene is represented in Plate V. of Virey's work. ${ }^{2}$ Beneath a group of sixteen persons is an inscription saying that these are the people of the islands which are in the midst of the green sea. They all wear long hair like the Cretans of the Minoan age, while the men of other countries have short hair ; they are carrying Cretan necklaces and vases, and wear shoes exactly like that of an ivory figure found at Knossos by Dr. Evans (Fig. I I 5 ). The sole of this shoe is clearly marked, and the upper leather shows

I Odyssey, iii.

2Virey, "Le Tombeau de Rekhmara," Mémoires de la Mission Archéologique Française, vol v., Paris, 1889. 
a seam in the same place where a modern shoemaker would make one. There are two cords at the ankle. On the tomb of Rekhmara all the shoes of the Cretans are white and have red and blue bindings. Several of them have elegant embroidery on their shoes, and their dress shows that they are ambassadors from a rich nation, for even the loin-cloths and belts which they wear are embroidered with rich designs of spirals, branches, and geometrical patterns. The costume resembles that of the frescoes in the

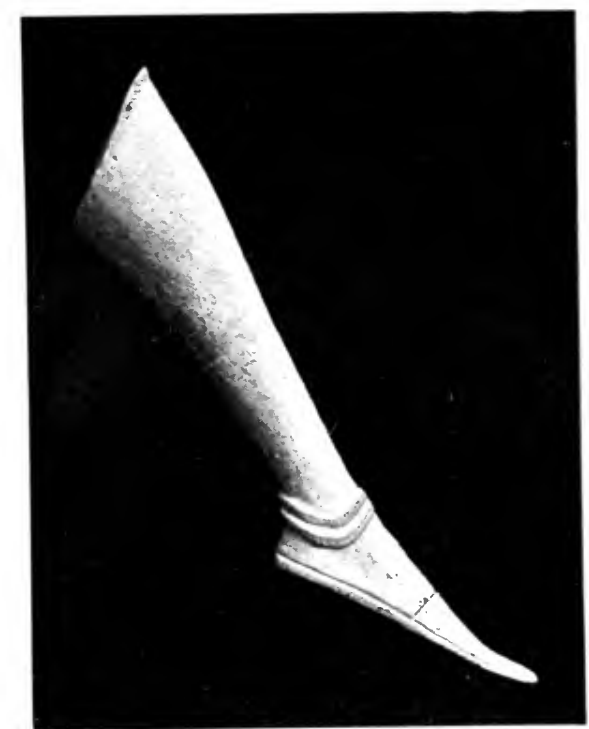

FIG. II5.-LEG OF AN IVORI FIGLRE FOLND AT K.NOSSOS 13Y DR. EVANS.

Museum at Candia, and this rich dress and footgear is in strong contrast with the modest figure of Rekhmara, who is attended by one servant and is noting the gifts brought by the Cretans. These gifts are vases of elegant form, like the Kamares vases with spirals and rosettes, hydrix with handles of classical form, such as were already in use in the Minoan age, and conical rhytons exactly like the vase carried by a youth in the fresco discovered by Dr. Evans in the palace of Knossos. Two men are each carrying an ingot of copper of the same shape as the nineteen ingots found at 
Hagia Triada. This point is important in connection with the history of metals, and proves, as I shall show in another work, that the copper mines of Crete were very productive, while those of Mount Sinai seem to have been less so. Another figure which is important for the study of metals is that of a man carrying on his shoulder a vase like those of alabaster found by Dr. Schliemann ${ }^{1}$ at Mycenæ, and holding in his right hand a dagger of Mycenæan shape.

The decorations of this tomb were sculptured fifteen hundred years before the Christian Era, and correspond to the second division of the latest Minoan period according to Dr. Evans's classification. They are of great value both in chronology and because we recognise in the work of the Egyptian sculptors many characteristics of the Cretan life of that period. The ideas of the Egyptian artists of the differences between the various races with whom they came into contact are clearly shown on the tomb of Rekhmara. In ethnological representations the Egyptians were capable of seizing the most evident points, and here, besides the long hair and the rich embroideries on the garments, they call attention to the elegance of the footgear, and have collected in a heap before Rekhmara all the most characteristic wares exported by the Cretans.

Although the Egyptians wore leather shoes, usually red or green in colour, the peoples of the Ægean so much surpassed them in the elegance and refinement of their footgear that, to mark the type of the Cretans whom they called Keftiu, they made their shoes of a different shape from those of the Egyptians and painted them white with red and blue strings, and patiently worked out the most minute particulars of the embroideries on the shoes, garments, pottery, and artistic objects of Cretan character.

\footnotetext{
I Schliemann, “Mykenæ," p. 283, Fig. 356.
} 


\section{CHAPTER XIII}

SCULPTURE AND PAINTING

I.

REEK art reached its highest perfection in three centuries. (I In Rome eight centuries were not enough to implant artistic feeling in the people. Till now this fact was supposed to show an enormous difference in the nature of the two peoples, but since the excavations in Crete we no longer see this great inequality. The Greek and Latin nations each passed through the same course of development in two stages with a long period of repose between.

The Renascence in Italy is as far from the apogee of intellectual development in Rome as the age of Perikles from the Mycenæan civilisation. The Middle Ages which followed the fall of the Roman Empire correspond to the period of darkness which came between the disappearance of the kingdom of Minos and the earliest Hellenic poems.

These great waves in the history of Mediterranean civilisation mark more plainly than historical coincidence the course of psychical laws.

Practice which perfects the brain is the foundation of that physiological development which in its turn prepares the aptitudes and gives the impulse to the creations of genius. The marvellous quickness of the awakening of Greek civilisation is accounted for by the culture which preceded it in the same way as the Italian Renascence has its roots in the energy which had disappeared 
with the Roman Empire. The intellectual life of a people feels all the hidden influences and benefits of nervous heredity. Successive generations during the process of perfecting themselves transmit to their progeny through the repose of centuries an ever higher elevation of inventive power.

The events of the Republic and the Empire were the period of probation and of preparation necessary to enable the soul of the Latin race to blossom anew in the Cinque Cento. But as there was in the Minoan period greater originality and a more intense artistic development than among the Roman people, so, after the stagnation of the Middle Ages before Homer, a correspondingly
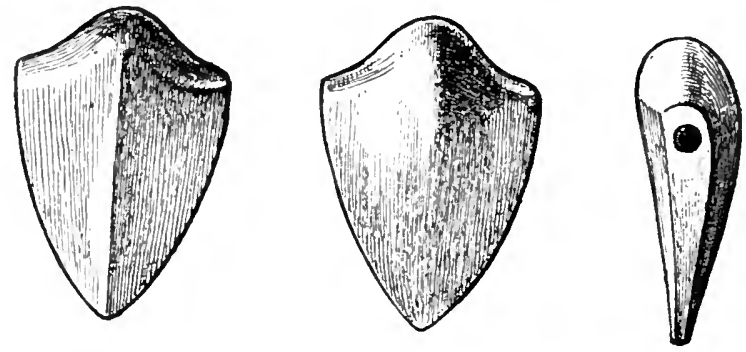

FIG. II6,-GOLD HEART-SHAPED PEXDANT FOUXD AT KXOSSOS I3Y DR. ETANS.

higher level of intellectual and artistic power was reached in classical Greece than in Italy of the Renascence.

II.

Primitive art in Crete is awkward, as we can see in the white marble idols. The vases of stone or terracotta are decorated with geometrical designs, but very early we find traces of careful observation of nature and of accurate study in the imitation of forms.

Heart-shaped gold pendants have been found in the most ancient sepulchres of Crete. It is evident from their shape that the artist had seen the human heart and copied it from the original. Other hearts had been worked with great care and 
patience from rock crystal. I give an illustration of a heart-shaped pendant in gold found by Dr. Livans at Knossos I (lig. 116). The shape is exactly that of the fleshy part of the heart, and the ridge which divides the cardiac muscle with greater prominence on one side than the other exactly represents the outline and details of a human heart.

The most ancient specimens of animal studies were found in a tomb or Tholos by the Italian Mission, near the villa at Hagia Triada. There are miniature statuettes of terracotta or steatite, some very beautiful, and a collection of ivory, bone, and steatite seals of various shapes, and all are perforated to allow of their being suspended by a cord. In one single tomb above a hundred were were found in the shape of discs, with small handles, or buttons, dice, or bells. An ivory cube, with an intaglio on each face (Fig. I I 7), shows signs of Egyptian influence. They belong to the second part of the first Minoan period, and are contemporaneous with the tombs near the village of Koumasa, where I studied the idols and weapons of copper

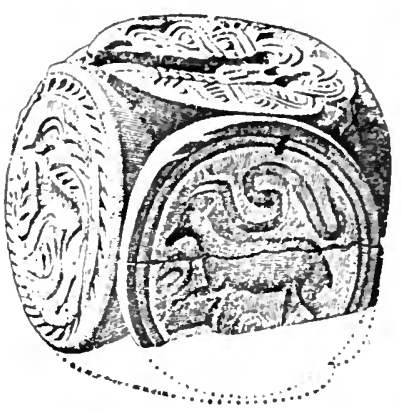

FIG. I I Ta.-WORY SEAL FOUND AT HAGIA TRIADA. and silver as well as the skulls. The figure of the wild goat, the sheep, and the sow show a certain skill with the burin.

\section{III.}

Animals of a less archaic period were found at Palaikastro, and have been described by Mr. Myres.2 They were votive figures, which were brought to a divinity regarded as a protector of health, and they belong to the middle Minoan period. With the animals many arms and legs were found; they are not made in a mould by the dozen, but each object shows some characteristic. Some have a perforation for suspension, others were

I Evans, "The Palace of Knossos," ii. p. 69.

a lide Chapter VI. op. cit. 
placed on the ground. Some arms have a bracelet painted in white on the wrist.

In accordance with what is becoming to the severity of a temple and to offerings made to a divinity in the hope of a cure, the nude figures are unsuggestive. Some pendent and flaccid breasts suggest scirrhus or cancer. In the female figures the sexual organs are sometimes clearly indicated, and possibly are ex voti for female diseases. Nervous affections are represented by hemiplegia, or paralysis of one half of the body, such as results from the bursting of a blood-vessel on the brain. Besides these figures, in which only one half of the body is represented, there are other votive objects, consisting of one foot, one hand, one leg, or one arm. Though it is difficult to be certain, yet we may be pretty

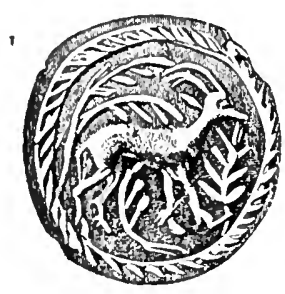

FIG. I I $7 b$.

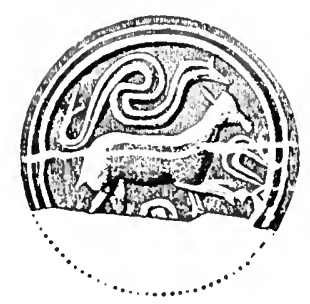

FIG. II 7 .

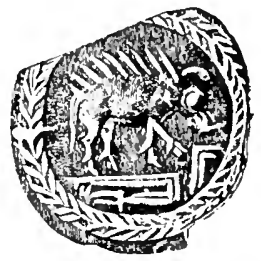

FIG. II $7 d$.

THREE FACES OF THE MORY CUBE USED AS A SEAL.

sure that maladies were distributed much as they are at the present time and that nervous maladies were represented by a greater number of votive figures for males than for females. Women are generally represented seated on separate benches; most of them are apparently young - the artist having made a point of indicating the breasts under the folds of the mantle, others are completely nude.

\section{IV.}

There is ample material for a study of the terracotta figures of animals in the Temple of Health at Palaikastro. Oxen are the most numerous; they are well formed, and are represented with a broad yoke hanging from the neck. The dogs are of a 
breed between the greyhound and the fox terrier, and resemble the characteristic breed now seen in Crete. There are tortoises, scarabs, and, in a vase, the figure of a seal. The great variety of species, which include the porcupine and the polecat, disproves the idea that they are all images of animals offered in sacrifice.

A terracotta cat found at Gournia, of which the head only has been preserved, is a perfect example of modelling. Moulds for making terracotta shells and lilies and small figures of the

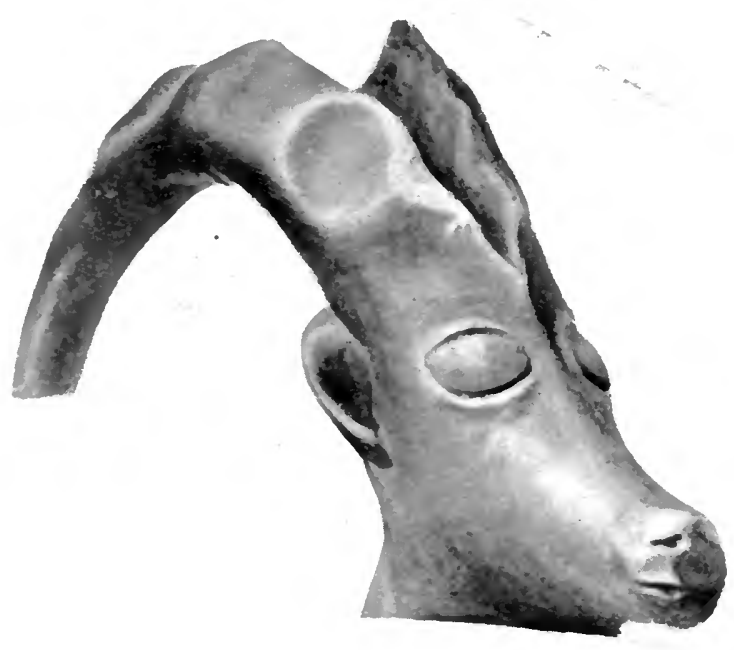

FIG. II8. - CRETAN WILA GOAT, TERRACOTTA, FOCNI) AT ZAKROS.

wild goat are found also. The skill with which these figures are made is shown by the fact that we can distinguish the wild pig from the domestic one. The sow has a well-formed snout, the back less hairy than the boar, also the ears are longer, pendent, and bent forward.

The head of a wild goat, resembling the agrimi, ${ }^{1}$ was found at Zakros (Fig. I 18); the horns and all the details of the head

\footnotetext{
I Capra agagrus, var. Cretensis.
} 
were executed in terracotta with perfect accuracy. Aristotle alludes to the wild goats of Crete, and when Spratt was making the map of the island he saw groups of forty goats at a time on Mount Ida. Homer described the great horns of these animals in the bow of Pandarus who wounded Menelaus. In a tablet found by Dr. Evans I fourteen is marked in Minoan figures beside the horn of a wild goat (Fig. I I 9).

A lady from Philadelphia, who was studying the antiquities of Eastern Crete, sent a telegram to the American Exploration Society which much resembles Schliemann's famous telegram when he discovered the treasures of Mycenæ: "I have discovered Gournia, a Mycenæan city, with streets, houses, pottery, bronzes, stone vases." If only for her pluck and capability Miss

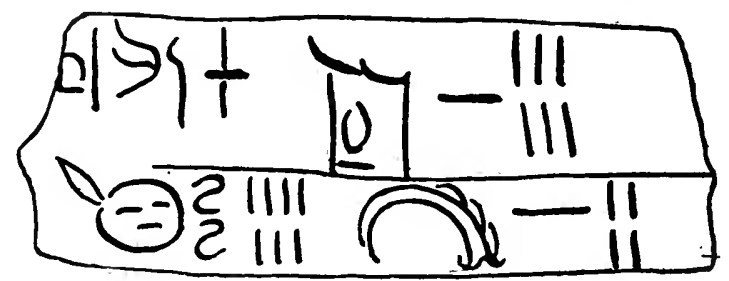

FIG. II9.-TERRACOTTA TABLET, WITH MINOAN WRITING AND FIGURES.

Harriet Boyd is worthy to be the heroine of a romance. An English archæologist, who had come from the University of Cambridge to visit the Mycenæan Pompei (as the Americans style Gournia), made Miss Boyd's acquaintance in all her glory, surrounded by more than a hundred labourers. He fell in love with her and married her.

I shall publish in another work four skulls of the Bronze Age found at Gournia by Miss Boyd. The object of the greatest artistic value found in one of the thirty-six houses excavated at Gournia is the head of a bull in clay (Fig. I 20), which resembles the famous silver bull of the tombs of Mycenæ. At that time, as with the Etruscans at a later date, the walls of rooms were 


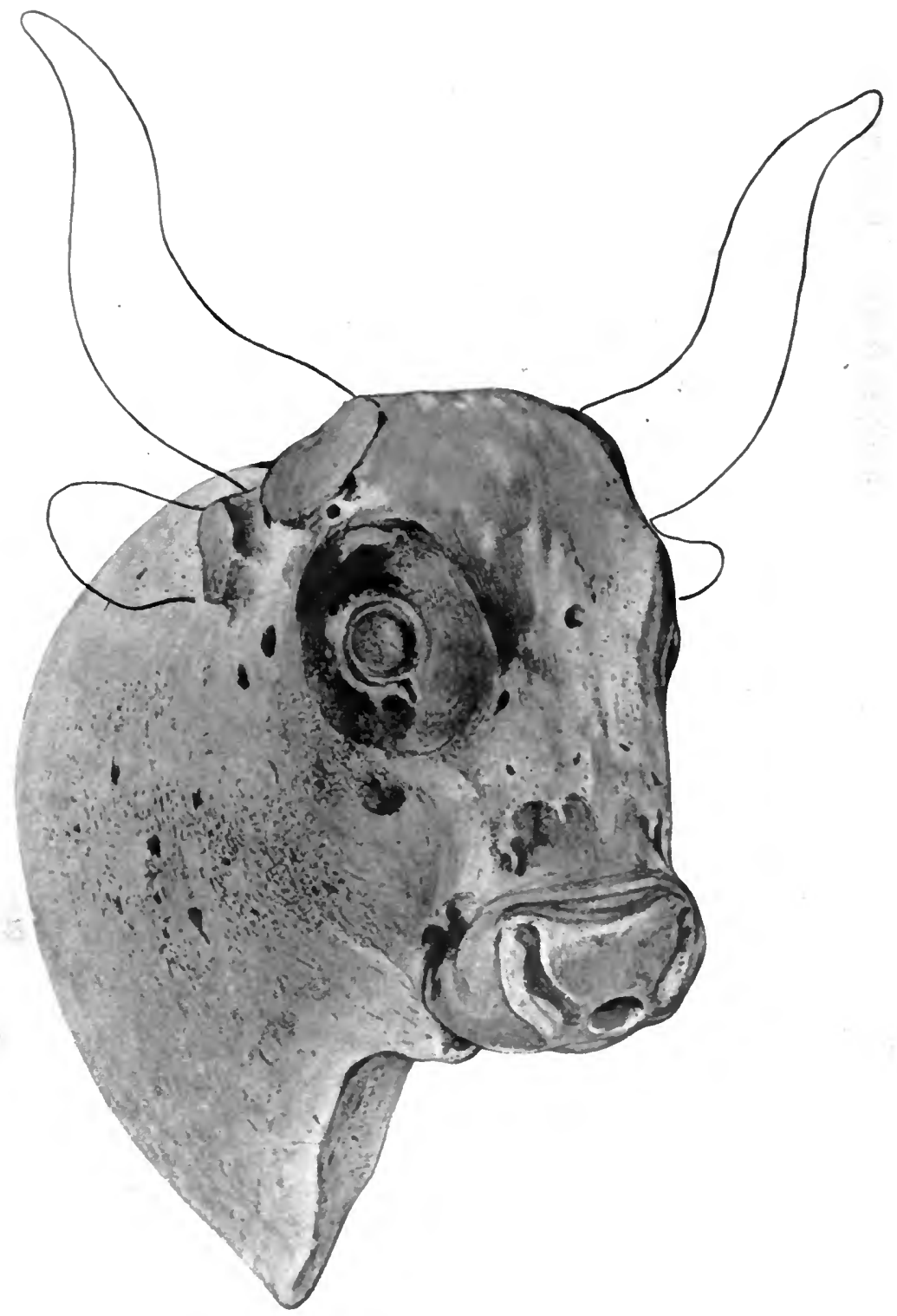

FIG. I 2O.- BULL FROM GOLRNIA. TERRACOTTA FOLNI) BY MISS BOYL. 

adorned with pottery and images of metal; the bull is an ornament of this kind, and was made to be fixed to a wall.

It represents a vase for libations, for it has a perforation through the nostrils, and another, which is not visible, between the horns, as in the vase discovered this year by Dr. Pernier at Phæstos.

\section{I.}

A book on the art of Crete in the Minoan and Mycenæan periods would be of great use to the historian. I myself have not the requisite training in these subjects, and besides, it would be necessary to have a complete collection of illustrations on a large scale. I will only say that nature has never been more faithfully studied, and that the art of the Minoan period can boast of a far larger number of examples copied from life than either archaic sculpture or the art of classical Greece.

In the Museum of Candia it is possible to follow the development of the various schools and the different fashions in which the style of Cretan art was modified. In the middle Minoan period the pottery kept the dark colours on a pale ground, or light designs on a dark ground, the polychrome style of the Kamares vases appearing later.

The vases of Zakros described by $\mathrm{Mr}$. Hogarth ${ }^{1}$ are masterpieces, and the Nymphra cerulœa is treated with exquisite delicacy on the bands round the vases. Centaurea cyanus appears also, drawn in white on a brown ground; these vases can certainly bear comparison for pictorial effect with the finest modern pottery. It was at this time that artists gave up the old style with the black ground and preferred decoration in brown or white on the yellowish ground of the clay.

As an example of faithful imitation of nature I reproduce some fragments of a vase with painted leaves and pods (Fig. I 2 I) discovered by Mr. Evans in the palace of Knossos. ${ }^{2}$

" Hogarth, "Bronze Age Vases from Zakros," Journal of Hellenic Studies, xxii. p. $333,190 \mathrm{I}$.

2 "Knossos Excavations," 1903. 
Nothing further is necessary to demonstrate the realism of Minoan art.

\section{VI.}

Moulds used for stamping artistic objects in faience (Fig. I 22) were found at Knossos, and there is no doubt that this kind of pottery is an imitation of Egyptian ware; the vitreous appear-

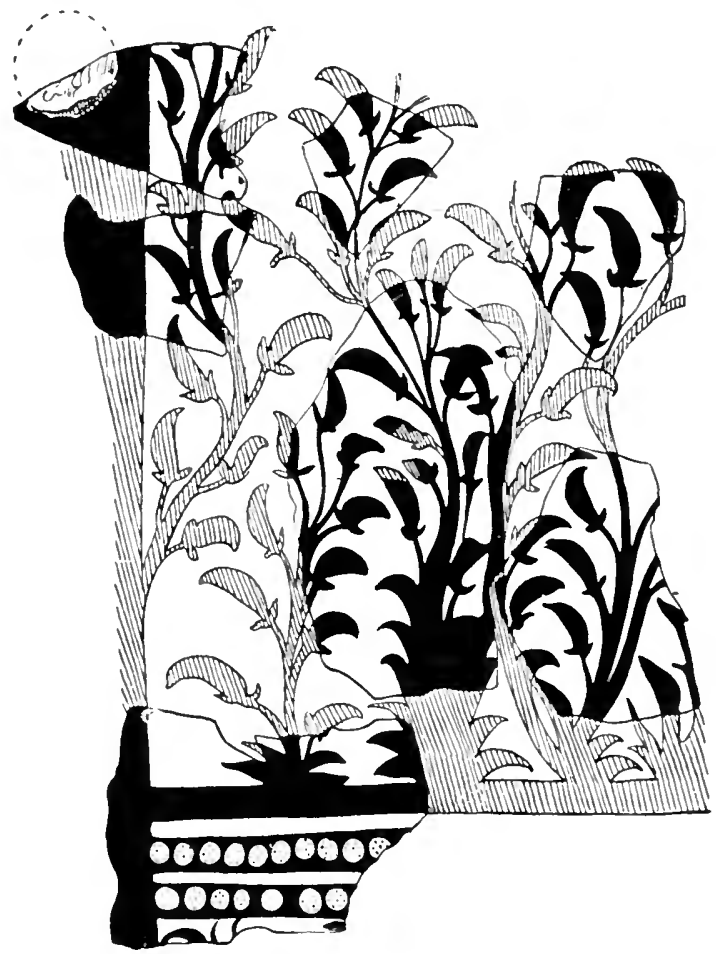

FlG. I2I.-KNOSSOS POTTERI.

ance of the surface shows the presence of quartz in the composition of the paste, and chemical analysis proves this.

Some small genre pictures representing maternal love are marvellous. A cow licking her sucking calf shows such deep and tender feeling that in comparison with this group Potter's bull seems a conceited egoist. Another pastoral idyl which breathes forth the charm of field life is a wild goat and a kid looking at each other and bleating while another kid is sucking. 
Fig. 123 shows an example of the skill with which the Cretan artists could reproduce animal life, the sulject is a wounded lion. This seal, on plaster, is so beautiful in its minute work that no modern artist could surpass it, nor could he render with greater truth the agony of death.

\section{VII.}

In some large marble receptacles containing cultus objects at Knossos, Dr. Evans found some small vases with the foot and

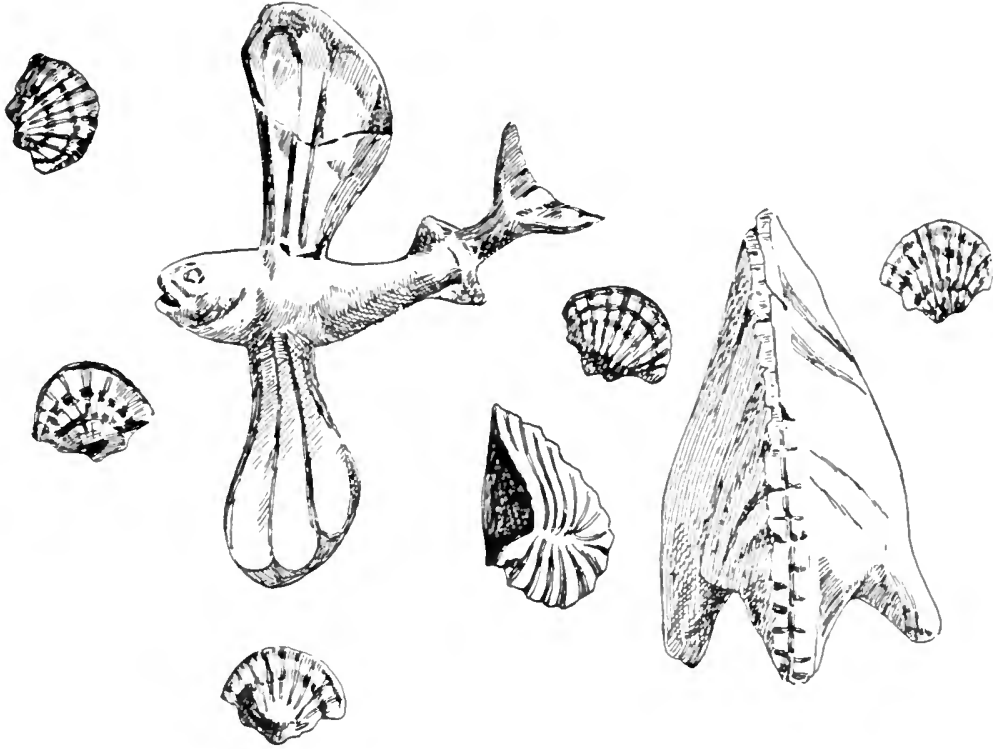

FIG. I 22.-SHELLS AND WISH IN PORCELAN, MADE IN MOLLDS.

neck of gold; objects of ivory and flying fish in faience (Fig I 22), wonderfully accurate imitations of the actual creatures of the sea. I give the photograph of a sea swallow which was caught near Candia (Fig. I 24).

The primitive folk must have been struck by this strange phenomenon when they saw it leap out of the waters of the sea to $f y$ in the air. As doves were a symbol of the heavenly powers who take possession of sacred trees and pillars, flying fish presented the same conception in the mythology of the sea. These 
fish are sometimes met with far from land; they rise in crowds round a vessel, and the flapping of their wings produces a sound like that of birds. They belong to the genus Exocatus. It is thought that they fly to escape from their enemies in the sea; they do not rise above 4 or 5 metres in flying. They usually fly in groups, touching the water and rebounding like a pebble thrown swiftly along the surface of a lake. When the sea fowl see them they follow them, so when these flying fish escape their enemies beneath the waves they meet others still more voracious in the air. Unfortunately, when out

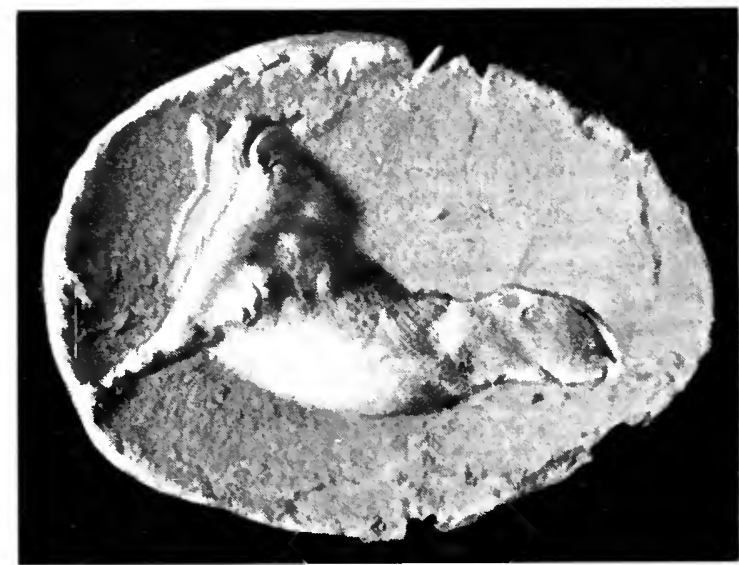

FIG. I23.-SEAI, REPRESENTING A WOUNDED LION, MAGNIFIED $\frac{3}{1}$, IN THE IUSELM AT CANDIA.

of water they do not see very well and strike their heads against the ship and are killed or fall on the deck.

In the fresco of Milos they are blue with red touches beneath the belly and at the eyes. They are drawn in freehand in various positions by the artists.

\section{YIII.}

From the earliest times the life of the sea has impressed a marine character on Minoan religion and art.

In excavations of the Neolithic age at Phæstos I found a 
number of shells of one species, different from the shellfish which are eaten. They are not pierced, and often they are much worn like those found on the shore, where they become blunted by being rolled about among the stones. The cult of the sea reaches without interruption from the Neolithic age to the Minoan period.

In the most ancient palace of Phastos some rooms were

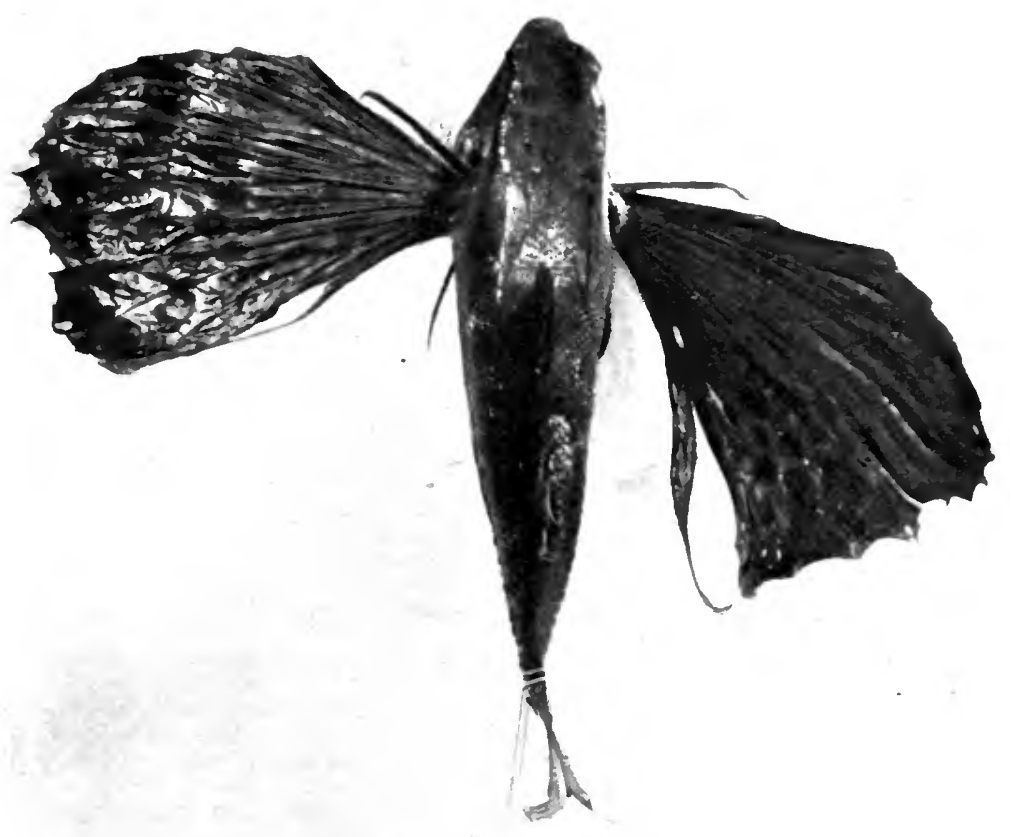

FIG. I24-DSEA SWALLOW CACGHT NEAR CANIIA.

discovered which had benches round and a libation table of black earthenware in the midst, such as was used in the Neolithic age. This vase rested on a bed of sand and pebbles in which the concave base of the vessel was sunk, and below this was a slab of alabaster. The shells placed round the vase were perhaps a record brought back from a sea voyage or an ex voto from the storms they had escaped. 
Shells with a cultus significance were found in large quantities before the Serpent Goddess. Many are made of a paste resembling porcelain and coloured green and red. I reproduce some, including the nautilus and pecten, which are the commonest (Fig. 122). In Mycenæan times and in the Neolithic period great triton shells are found, both real and imitations in stone.

On the intaglios for seals we find priestesses sounding the shell of a sea triton to call the divinities to the altar, just as the Cretan shepherds do now to collect their flocks.

Corals, too, were made in porcelain and placed among the shells as if at the bottom of the sea. Great skill was shown in this style of decoration, as may be seen in the vases on which polypi and seaweeds are interlaced. A sacrificial vase, which I saw excavated this year at Phæstos by Dr. Pernier (Fig. I 25), displays a most graceful decoration of this type. The corals interlace their branches in fantastic shapes, and in the midst of the floating seaweeds the argonaut with its elegant shell stretches out its arms covered with suckers. The artist has sketched the design in freehand with sepia, repeating the same motive with slight variations.

This vase is double, a cone descends from the neck nearly to the bottom, and at the bottom the vase has a small opening. We may suppose that it was filled with wine and held upside down by the person offering the sacrifice, and so the liquid could not escape. Approaching the altar while the fire was burning, he would pour the wine upon the flesh, reversing the vase. Thus are the sacrifices described in the Homeric poems.

The nautilus shells in faience are like Japanese work; lilies, crocus flowers, and shells of various kinds are imitated from life with scrupulous accuracy. Even most humble utensils bear the design of a net with some sea creature in it. Artistic genius is displayed in the dexterity with which the life moving in the waters is indicated and the most elegant and poetic forms chosen, such as the nautilus, sepia, corals, and starfish ; also in the manner in which the extremities of the seaweeds are drawn swimming 
in the water, with touches of various colour to increase the relief.

\section{IX.}

Crete is a world in the midst of the Mediterranean, till now unknown, but suddenly revealed to our gaze. The civilisation which was the origin of Greek culture had disappeared; neither

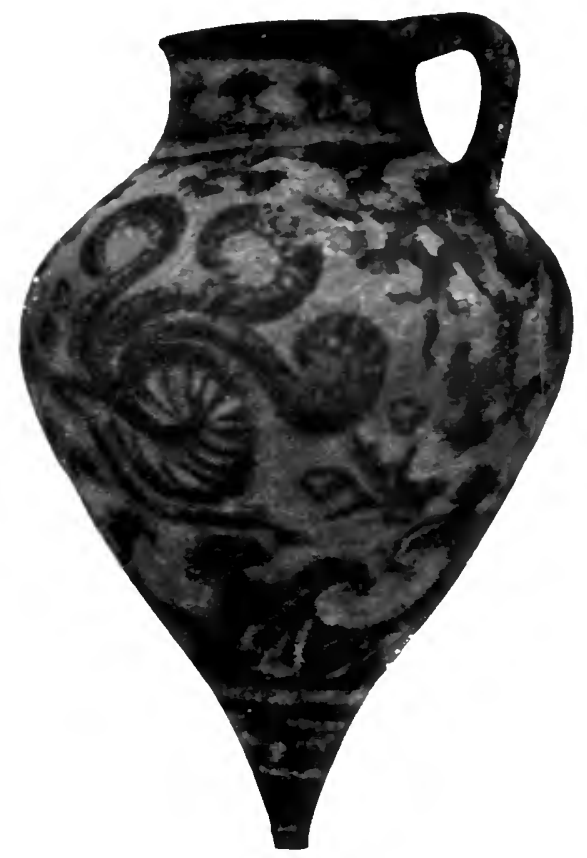

FIG. I25.-VASE FOR POCRING WINE IN THE SACRIFICES, DECORATED WITH NALTILCS, CORAL AND SEAWEED.

Herodotus nor Thucydides name her, and there is only some slight allusion to Crete in the Homeric poems. As there are stars in the sky which have disappeared before the beginning of history, and which we only see now from the earth by the blaze of the catastrophe which destroyed them, so can we now admire the art, the creative power, and the riches of the Minoan people. 
Art was a necessity deeply felt by these people-it was a joy in which all the dominating power of the sea shines out. And after so many thousands of years it seems to us as the synthesis of the intellectual work of the centuries of history which are still wrapped in darkness. Minoan art was original and typical like its civilisation; the sympathy between the inventor of a form of beauty and the satisfaction of those who enjoy the contemplation of it was then, as now, the fruitful soil in which the germs of art have developed.

The creative power of Cretan artificers proceeds from their constant search, throughout all ages, for characteristic expression of forms : and the foundation of Minoan art is based on the constant development of the ability to reproduce the aspects of nature for the attainment of a faithful representation of beauty.

An idea of life emerges from the study of Cretan archæology in all the forms through which technique and composition have passed; in sculpture, design, and architecture, it is a plant of which we see the birth, growth, and dying away. Life projects itself into art and is materialised in the determination of its aspect.

The palette of the fresco painter was simple; those who have studied the question I think that only five colours were usedblack, white, blue, yellow, and red. It seems to me strange that green should be omitted, for this colour is produced by mixing yellow and blue, and can easily be obtained from salts of copper, among which the carbonate exists in abundance. There are in fact near the Serpent Goddess shells which have been coloured green, others half green, half brown, again others streaked with green alternately with black or brown. Artificial shells, too, imitations of scallop shells are coloured green.

On the great larnax of Hagia Triada are two pedestals, on each of which a shaft of the height of a man is fixed, at the top of this shaft is a double axe. One of these shafts is coloured pink, the other on the opposite side of the larnax is covered with 
leaves which are distinctly green. Professor T'sountas, too, found green among the colours in Mycenxan paintings. ${ }^{1}$

The colours of antiquity are worthy of careful study; it is a subject in which a certain degree of education is necessary for the perception of the different lengths of the waves which produce colour sensation. Peasants are unable to express themselves clearly in these distinctions and there are persons who confound violet with blue. At the time when Gladstone said that in the poems of Homer there is no word implying that the poet had any distinct perception of green or blue, ${ }^{2}$ the strangest things were published and the height of absurdity was reached in the idea that sensations not mentioned in the Homeric poems did not exist. It was formerly said that Homer was colour blind, but as it could no longer be allowed that all the books of the Iliad and Odyssey were written by the same person, it was said that the various nervous centres which serve for the perception of colour were not yet developed. The simplest way is to attribute no importance to the lacunæ in the Homeric poems.

In some of the trescoes I admired the art of the Mycenæan artists who have painted the leaves of plants in brown upon a red ground so as to produce an optical illusion of a beautiful green through the effect of the complementary colour.

Painting remained in the infantile stage in which men are drawn in profile. Foreshortening is so difficult that the Egyptians drew the head in profile and the thorax from the front, so as to avoid the difficulties of perspective with the shoulder. Then, again turning the figure, they drew the

I I only quote these examples and could give others showing the incorrectness of the statement in Perrot and Chipiez's otherwise valuable book, that a real and primitive green is nowhere found ("Hist. de l'Art": La Grice Primitive, p. 533). Professor Schiaparelli, director of the Egyptian Museum at Turin, gave me a small quantity of green broken off a lump the size of a nut, which he found at the level of the water in the stratum of the prehistoric period on the site of the city of Heliopolis. I analysed it and found that this olive green powder is of the same composition as turquoise, as it contains phosphoric acid, aluminium, copper, and lime.

- Op. cit., p. I 92 . 
legs in profile. In spite of these limitations Mycenæan pictures are elevated in subject and composition.

\section{$\mathrm{X}$.}

For the better understanding of Cretan art and its most important phases the study of the octopus will help us to appreciate the gradual development of form till a standard of

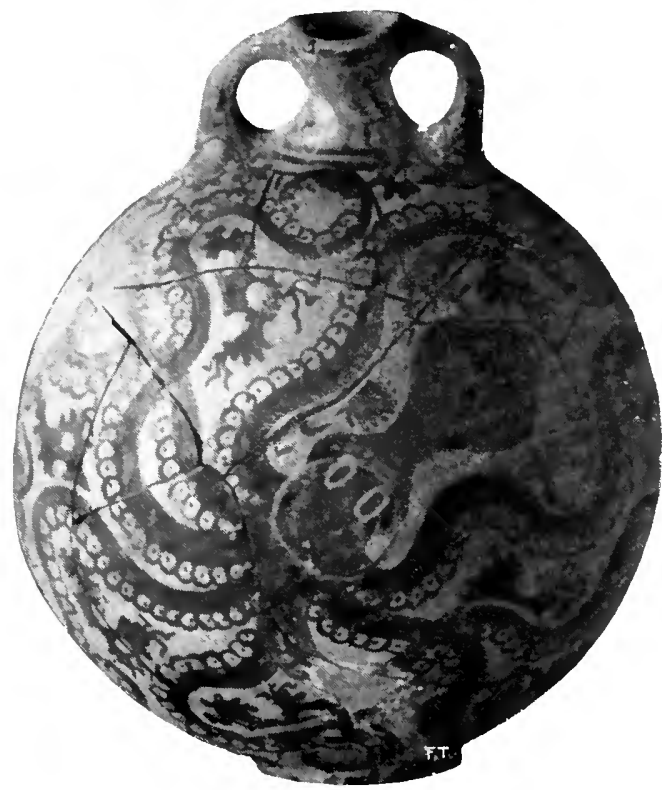

FIG. 126.-POLYPUS DESIGNED IN THE BEST PERIOD OF MYCENAAN ART.

conventionality was reached, and then through a process of degeneration the animal became almost unrecognisable.

The polypus is a common motive in the decoration of pottery, The design of Fig. I 26 is of the first period and is correctly drawn. In the second period the time of decadence has begun (about I600 B.c.), the painting of the polypus is less perfect, the head is too large, the feelers are less naturally bent, and the suckers are absent. Fig. 127 belongs to the third period of the 
latest Minoan epoch; the conventionalism is more advanced, the eyes and head are developed to excess, and the body is so atrophied as to be unrecognisable. The tentacles have shrunk into a sinuous line, and, instead of eight, there are barely six of these wiry arms. This stylisation of the octopus is so exaggerated on some of the larnakes that the animal is only indicated by a sinuous line, and the head disappears with the remainder of the body.

These phases of stylistic degeneration are very evident in the representations of the bull from the dawn of art to the decadence of the Mycenæan period, when Art enters on her second childhood.

In the reliefs at Knossos ' ${ }^{\mathrm{I}}$ the modelling of the bull's head is perfect. The nostrils dilate with a deep inspiration, the mouth half open, the eye furious and starting forth in the congestion of the rush-all give a strong impression of fighting. The bull from Gournia, discovered by Miss Boyd, 2 belongs to the third period of the primitive epoch, and is contemporaneous with the VIth Dynasty in Egypt. In spite of the remoteness of the age to which it belongs, it is an admirable piece of work, and worthy to mark the advent of pre-Hellenic art.

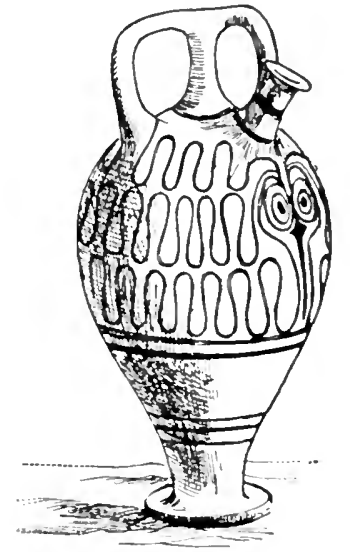

FIG. $127 .-$ MOLYPUS DESIGNED IN THE: LATEST MYCENAAN PERIO1).

A terracotta head which I saw excavated by Dr. Pernier at Phæstos shows how the later Mycenæan artists gradually forsook nature (Fig. I 28). This is a sacrificial vase, and would be filled with wine through an opening between the horns, and the wine could then be poured from the mouth. A first sign of decadence

"Evans, "Knossos," Annual of the British School at Atlens, vol.vi. p. 52.

2 Harrict Boyd, Gournia Transactions, Uniecrsity of Pennsyliania, vol. i. No. 1, p. 43, 1904. No further illustrations of bulls are given, as those in Chapter XI. show in how life-like a manner the bulls are represented in the taurokathapsia. 
is apparent in the two ridges above the nostrils. This is not an attempt at rendering a cord tied round the muzzle, for the artist has not continued this cord round the mouth. The same is seen above the eyelids, where one ridge would be sufficient to form the

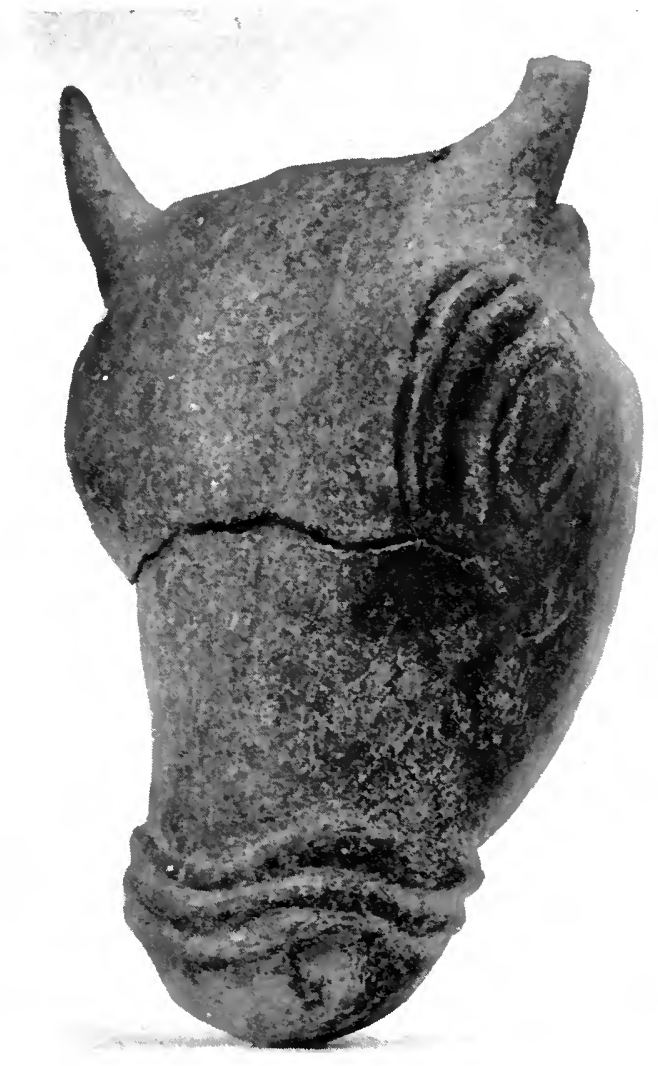

FIG. I 28.-SACRIFICIAL VASE FOCND AT PHESTOS BY DR. PERNIER.

eyebrows, and the artist has made three, and has also been unfaithful to nature by making the ears and horns too small. Art continues to degenerate, and the last phase is seen in the images of oxen found at Hagia Triada, where they have lost all semblance of life. There is abundance of this kind of pottery, and I, too, have found at Hagia Triada an ox with the same 
decoration of rayed lines round the eyes (Fig. I 29). 'Taste was now so corrupt that the former ridges which appear on the nose of the bull (Fig. I 28) have here become six lines. There are painted rings round the horns, and lines passing down each horn join on the forehead, and are prolonged to the nostrils. Fig. I 30 shows some of the terracotta animals found at Hagia Triada, which testify to the extreme decadence of art in the latest period of the Mycenæan epoch. I have included a horse carrying two vases as an example of the Mycenæan horse. These votive figures of animals represent the offerings of poor people, and were probably made to be sold by the dozen, and are therefore a less certain

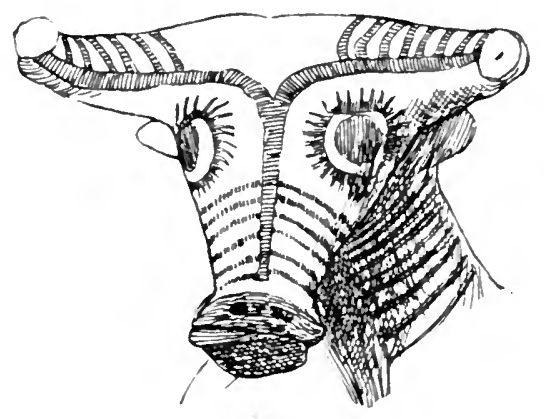

FlG. I 29.-HEAD OF AX OX. STYLE OF THE DECADENCE IN MYCENAAN ART.

indication of art and style than the vases which show the same decadence.

\section{$\mathrm{X} I$.}

In no other museum of art than that of Candia is it possible to study all the phases through which art has passed during the centuries from the Neolithic age to that of Mycenæ. The descending series of the senile period is more instructive here than elsewhere, because that decadence takes its natural course, and the gradual change of artistic feeling to the stylised forms of conventionality and concomitant neglect of the imitation of nature can be followed step by step. 
A person who had not followed the gradual degeneration of Mycenæan art might imagine these figures to be samples of cheap terracottas, such as the children's toys now sold at fairs, but the truth is that, as the golden masks of Mycenæ prove, no one was now able to make anything better. The same faults appear in the animals painted on the larnakes; they have an infantile appearance, and their species can only be recognised with difficulty.

Such was the evolution of art from its infancy to maturity and old age. In modern times the influences and currents which affect the culture of a people are of greater intensity, and the life of art no longer follows its natural course in individual nations.

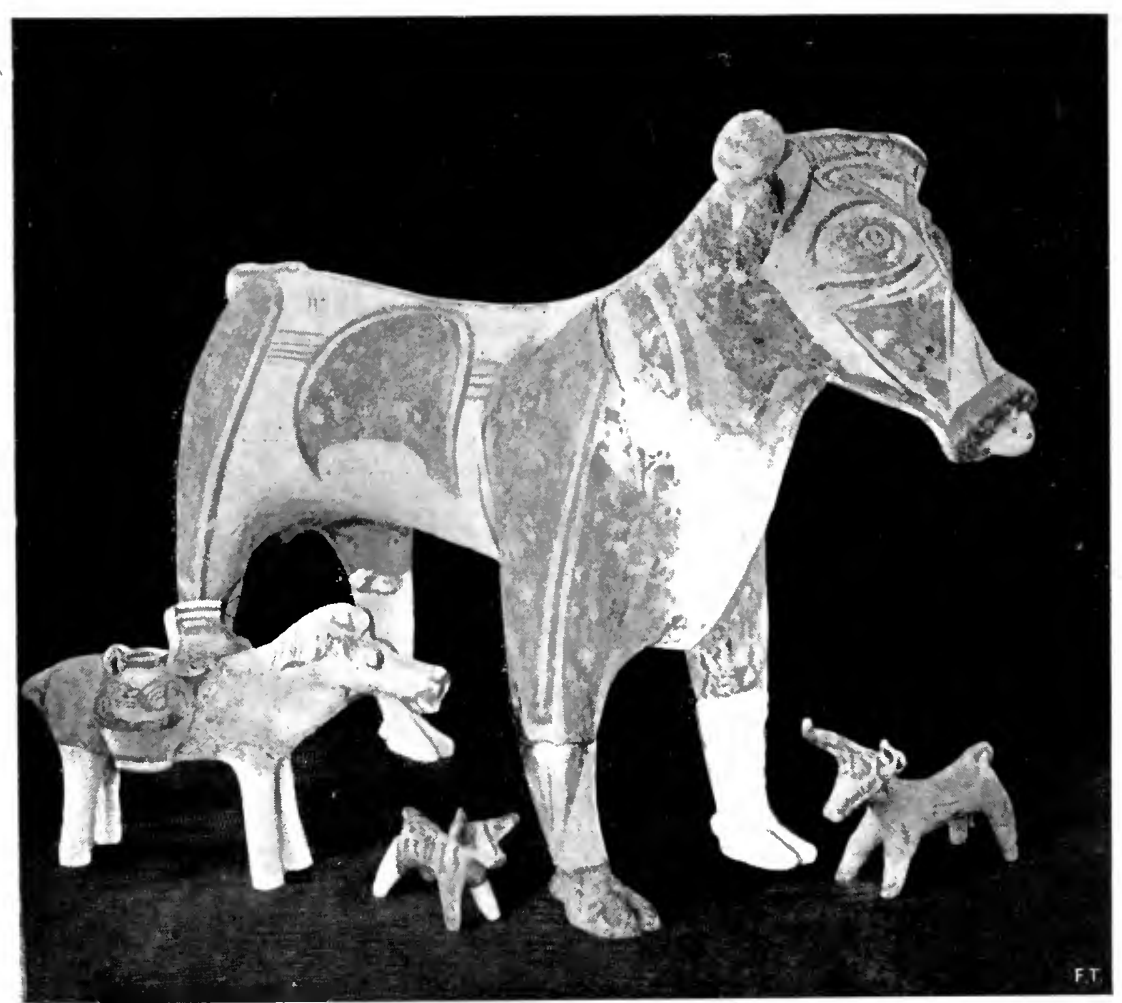

FIG. I3O.-TERRACOTTA ANINALS OF THE PERIOD OF DECADENCE IN MYCENAAN ART. 


\section{CHAPTER XIV}

WOMAN IN THE ANCIENT RELIGIONS

I.

D URING the excavations at Phastos I found in the Neolithic stratum a female image of hard unbaked clay (reproduced in Fig. I3 I, I centimetre taller than the actual size). Above the right breast there is an opening which crosses the shoulder, and probably served for attaching the head. The thighs had been truncated, so that the statuette could stand straight on its round basis. The deep groove above the hips passes across the back, round the body, and under the abdomen, where a triangular marking represents the organ of generation. The back parts are as protuberant as in the women of the Hottentot and Bushman tribes. Images which show this adipose formation in the gluteal regions are said by archrologists to belong to the "steatopyge" type. Female statues of the Neolithic period found in Italy and France show the same protuberances at the base of the trunk, and are thus differentiated from the forms of European races as we know them.'

If we compare these statuettes with the later archaic Greek work, e.g., the famous discoveries on the Acropolis of Athens, we shall see how the Greek ideal of beauty changed. Certainly the conception of female charms before the bronze epoch was very

"In my work, "Idoli feminili e figure di animali nell' eti neolitica" (Memorie della R. Accademia delle scienze di Torino, 1907), I publish female idols found in Italy similar to those of Crete. 
different from later ideals, and the early artist evidently exaggerated reality in order to emphasise the profile of the form, and render it pleasing to primitive man. A small cross on the hip of the statuette suggests tattooing, and this proves that the Cretans passed, as all nations did, through that stage of barbarism in which tattooing and scars on the skin were a distinction and an ornament.

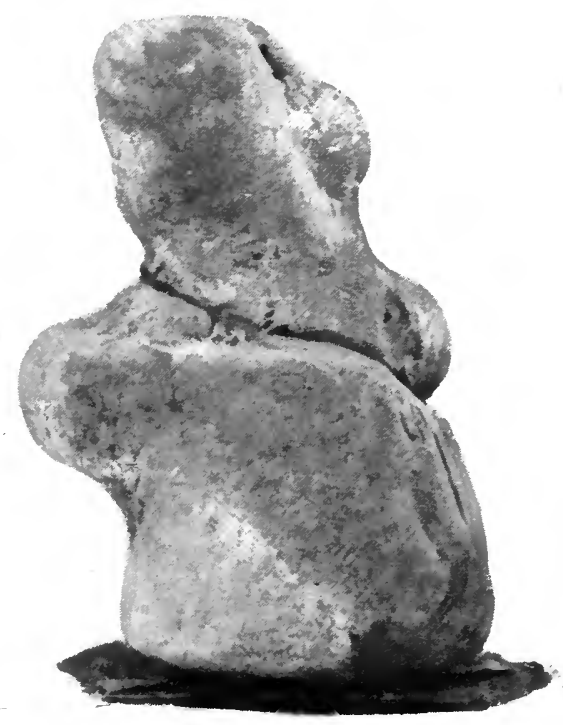

FIG. I3I.-FEMALE IDOL FOLXD AT PHASTOS IN NEOLITHIC SOIL NEAR A MAGNETIC STONE.

In early religions the divine ideal takes a female form. From the Neolithic to the Mycenæan age male images are the exception. It is worth while to examine into the causes of this preference.

Dr. Xanthoudides, Ephor of Antiquities at Candia, found, while excavating at Koumasa, near Gortyna, some very ancient tombs belonging to the third period of the first Minoan age 
(according to Evans' Chronology) (Fig. I 32). 'The weapons contained in these tombs, and used during that period, were short, triangular daggers made of copper and silver. There was an earthen vase in the shape of a pitcher, decorated with geometric designs of plaited bands in the style which preceded that known as "Kamares." 'Three small bucchero vases with lids, fastened to one stand, were probably intended for use in worship, and are like those found in the pile-dwellings

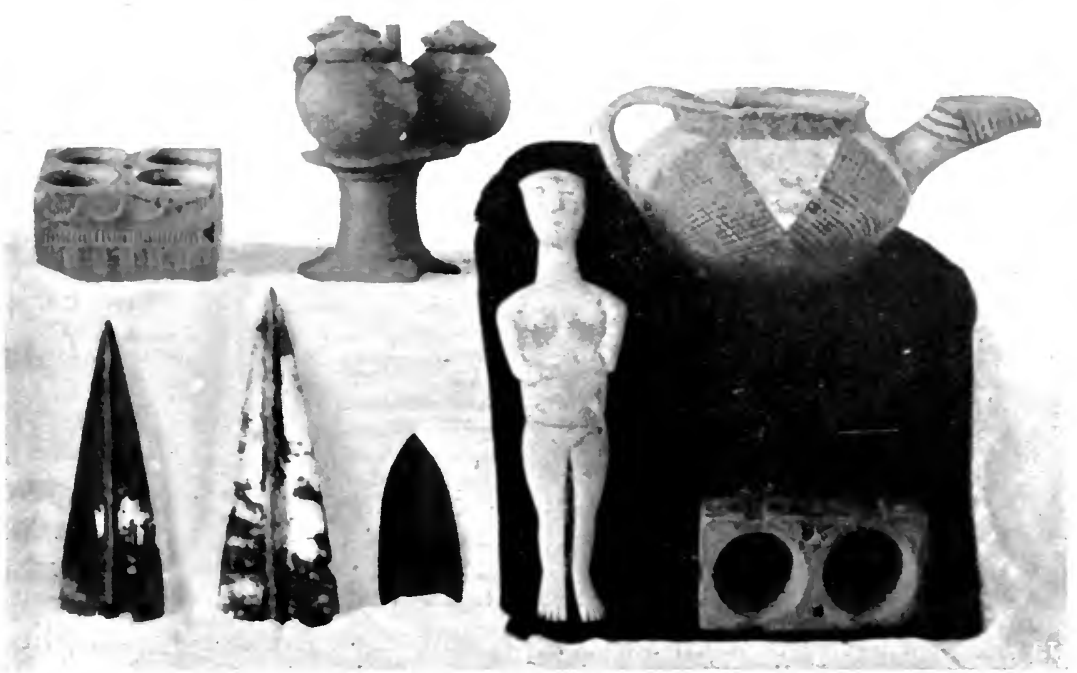

FIG. I32.-OBJECTS FOCXI) IN A TOMB OF THE FIRST MINOAN PERIOI), AT KOCMASA, BY DR. XANTHOUDIDES.

Female image in marble, weapons in bronee and silver, vases in stone and terracotta.

of the Italian Lakes. The square steatite vases, decorated with lines and circles, were used for libation. Similar vases were found by Schliemann in the ruins of Hissarlik in Asia Minor, which he identified with the Citadel of Troy.

The little marble statue found with these vases represents a woman with clasped hands. Images of this type, all female, are very abundant in the Cyclades. ${ }^{I}$ In the Museum at Athens

"Schliemann found about six hundred of them at "Troy and Mycenx (“Mycènes," p. Ifl ; "Troie," p. 399). 
there are some more than a metre in length, all of Parian marble.

The spirit of conservatism is strong in religion. Thus in the temples of classic Athens, beside the masterpieces of Pheidias, were preserved the sacred xoana, statues roughly hewn out of slabs of wood or stone. In the third tomb at Mycenæ Schliemann found two images made of gold leaf (Fig. I33), representing the Goddess Aphrodite. A dove is perched on the head of each, and one of them has besides a dove on each arm. They wear a diadem, and the hands are pressed to the breast in the attitude of the terracotta figures of Cyprus and the marble statuettes of the Cyclades. There are holes, evidently for sewing them to dresses, and the figure with three doves must have been fastened by studs, still to be seen between the knees and on the abdomen. The nudity of the figures is almost ostentatious. When we look at these poor attempts of early art it is difficult to remember that such figures were the forerunners of the Venus of Melos and the Cnidian Venus.

\section{II.}

Aphrodite is represented nude, for during part of the Archaic period it was the custom so to represent divinities. On intaglios and seals women at altars are usually naked to the waist. Possibly this was part of the religious ritual fashion. There is no doubt that the early artist tried by means of these figures, rude though they be, to express the universal and instinctive passion of love. Hesiod says that Aphrodite was born of the sea-foam, and modern science, confirming this poetic idea, tells us that the sea is the origin of life and that within it are to be found progenitors of all animal species. Diodorus Siculus I recognised the importance of Crete as the cradle of Hellenic religion when he wrote: "The Cretans assert that honours paid to the gods, sacrifices and initiation into the mysteries are Cretan discoveries which were borrowed by other peoples." 
Artemis was the goddess who represented Nature as feminine, the teeming Warth, the type of health and vigour, as Homer says. Rhea was the mother of Zeus, and the worship of the Mater Deorum took its origin in Crete. A bas-relief in the Vatican represents a High Priestess of the Great Mother, in whose honour the Romans coined money and celebrated a solemn festival in the month of April.

In 1903 Arthur Evans made a series of memorable discoveries which add greatly to our knowledge of Minoan religion. In the
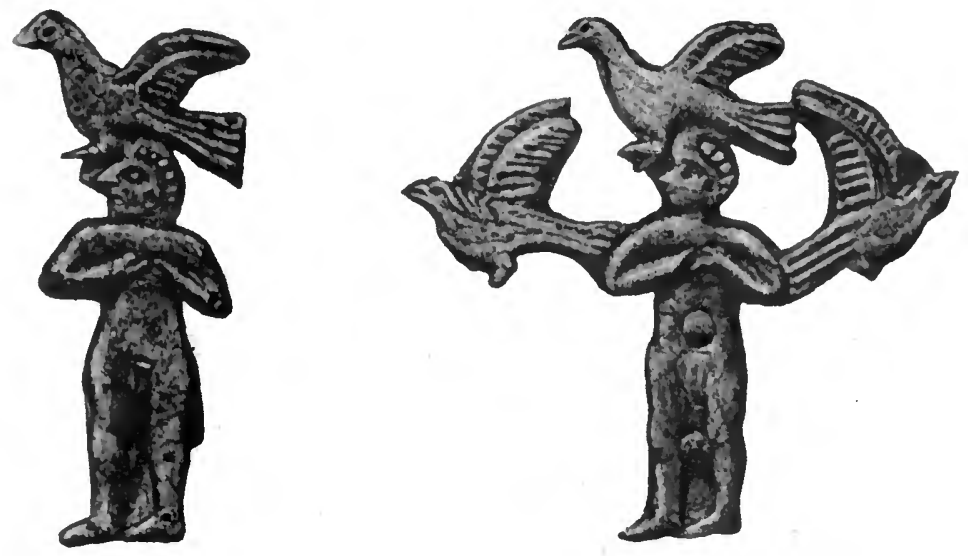

FIG. I33--FIGCRES OF WOMEN WITH DOVES STAMIEI) OLT OF GOLD LEAF, FOUNI) AT MYCENA BY SCHLIEAANN.

centre of the palace at Knossos he found a sanctuary containing two large stone chests. In the chests were preserved some objects intended for cultus. The chests are made of large slabs of stone, well joined. Their length is 2 metres and their depth $1 \frac{1}{2}$ metres; under a covering of charred wood lay the cultus objects together with a faience figure of a priestess and the votive garments described in Chapter VI.

We seem to see here, at its pure source, that stream of religious feeling which was directed towards the adoration of female beauty. The artist, imperfect in his craft, had no 
command of æsthetic forms, but he could express with truth and vigour his adoration of the maternal principle.

Human fancy may have created myth, but the supremacy

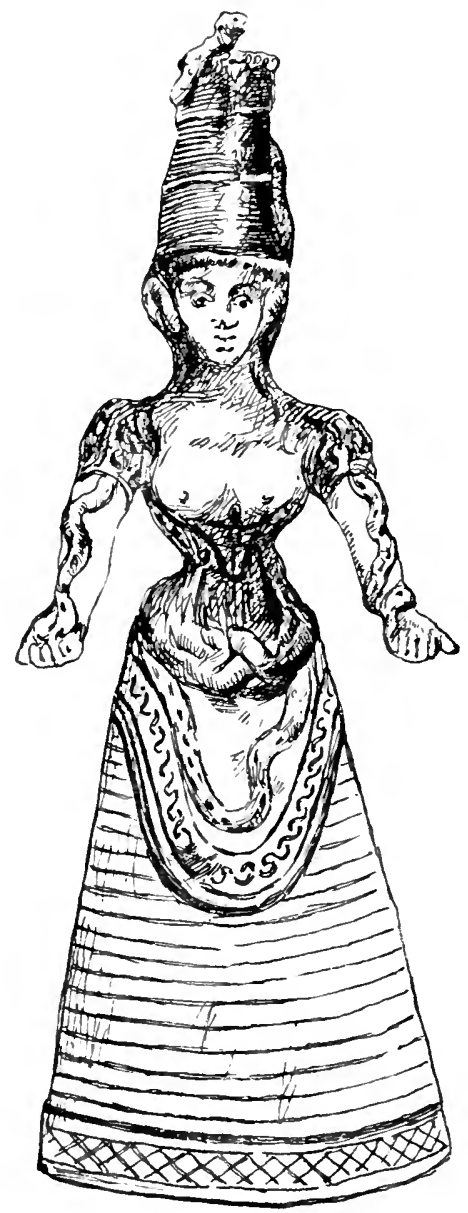

FIG. I34.-THE SERPENT GODDESS, SO NAMED BY ARTHCR EVANS. in religion accorded to woman must have been due to the instinct which venerated her life-giving functions.

One of these statuettes is called by Dr. Evans "The Snake Goddess" I (Fig. I34). The arms are extended. The right hand holds the head of a serpent whose body passes over her shoulder and down her back. The left hand holds the serpent's tail, which is wound round her arm. Another serpent rears its head over the mitre which the goddess wears, and its coils slip down over her neck and uncovered breast, and mingle with her regular snaky curls. The sleeves of her dress are short, the petticoat, striped horizontally, is edged with an embroidered trimming, and an apron in front, of rounded shape and trimmed with a Greek key pattern, is matched by a similar drapery hanging down behind. A fine spiral ornament begins on the shoulders of the bodice and is richly developed on the back. The resemblance in dress and coiffure between this goddess and the priestess is so striking that I am inclined to call them both priestesses. Perhaps the dress of the priestess is rather less richly ornamented than that of the "Snake

$$
\text { r “Knossos Excavations," p. 90, 1903. }
$$


Goddess," but this detail does not justify a great distinction in interpreting the figures. In both the matronly ideal is predominant. In ancient art and ancient religion there is no such idea as a girl Venus. She is exclusively goddess of fertility, the symbol of Mother Nature, teeming and fruitful.

\section{III.}

The discovery of a marble cross among other cultus objects is worthy of remark (Fig. I 35). The cross as a Mycenaan symbol, was known from the marked stones in the palaces of Knossos and Phæstos, and indeed the juxtaposition of two straight lines intersecting at right angles must have been one of the earliest of geometric designs. This example, however, is different. It is a solid object in the form of the orthodox Greek cross, and must have a religious meaning. I The fact that one surface is smooth and the other rough shows that the cross was fastened to some larger object.

Evans suggests that the cross is a simplification of the star form, and may stand for the cultus image of the sun.2 If this be so, the finding of the cross with the "Snake Goddess" and her priestess confirms me in the opinion that these female figures were not of divine rank, but were votive offerings placed on an altar dedicated to the Sun. Painted shells were placed before them and, at their side, the votive garments in porcelain that we have already seen.

In sacred rites women were not merely spectators. This is evident from the appearance of a woman in the "procession" fresco at Knossos. She wears a petticoat adorned with elegant embroidery. The men walk towards her and are all shod.

In the fresco of the temple we have seen that a woman

"The material is grey marble with white veins. It is $22 \mathrm{~cm}$. high and is cut out of a slab I 2 millimetres thick. On a Mycenean seal there is a cross with a long vertical shaft; a gold cross iike a modern pendant was found at Mycena and another, of porcelain, at Knossos.

\footnotetext{
2 "Knossos Excavations," p. 92, I 903.
} 
is placed on a high seat near the sacred horns. The privileged condition of woman in religious rites is conspicuous both in the Minoan civilisation and in that of Etruria, and is one link in the chain of evidence that they are related. In this particular both differ from the civilisations of the East. When the religion of Crete was transported to Delos, as the historians relate, it was the priestesses who made the temple of Apollo famous,

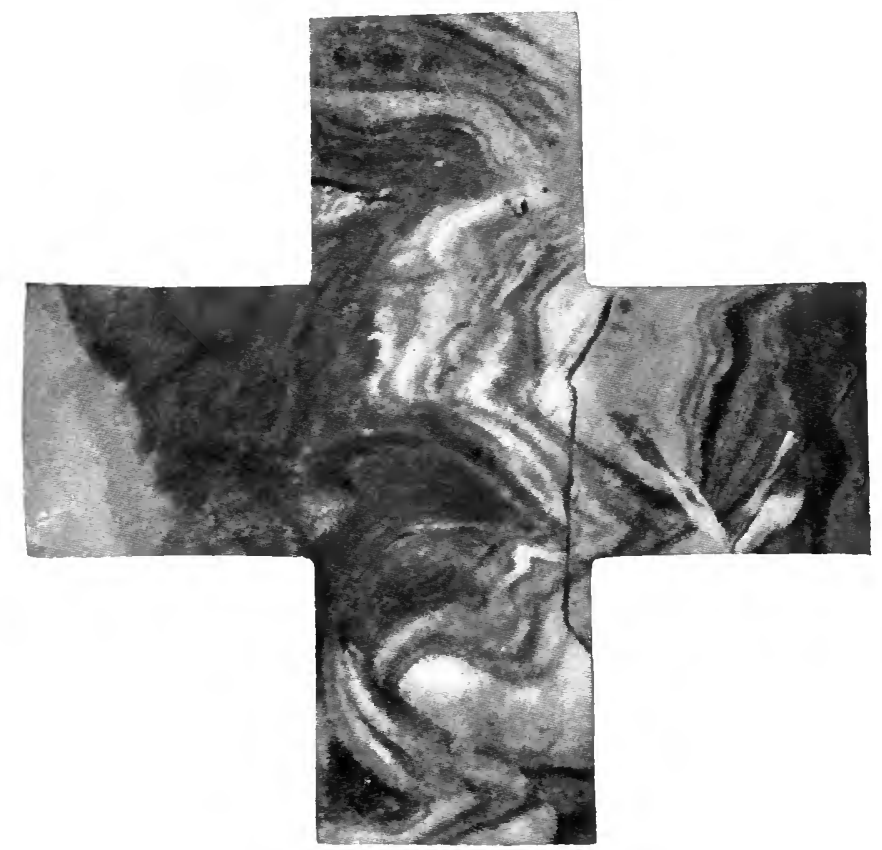

FIG. I35. - MARBLE CROSS FOLND AMONGST CULTUS OBJECTS AT KNOSSOS BY DR. EVANS.

and maidens crowned with flowers danced in a ring round the altar.

The priestesses represent a root idea of Greek religion, and the Etruscans brought this idea to North Italy before the Greeks colonised the South. Etruscan processions, "pompe," and sacrifices were all copied from the worship in Argos, Mycenæ, and Tiryns. The honour paid to woman in Etruria, her equality with men at feasts and sacrifices, justifies us in assuming an affinity 
between Etruria and Argos. In Etruria the importance of woman in the family was greater than in the Greece of the classical period. In the Minoan civilisation and in Etruria sons took the name of their mother. Other analogies are plainly to be seen in architecture, art, and costume. Livy, in his account of Tanaquil coming to Rome, says that Etruscan women acted as priestesses. I

\section{IV.}

In order to visit the Cretan cave of the goddess Eileithyia, mentioned by Homer, I took a boat at Candia and landed at the mouth of the Amnisus. The stream winds its way through the valley, which is planted with olives. A ruined aqueduct is the only relic of this ancient port from which Minos ruled the Ægean.2 Feeling our way, we penetrated the mysterious twilight of the cavern. We were in the sanctuary of the goddess Eileithyia, feared by the unchaste and invoked by mothers. Dr. Hazzidaki had told me of the Mycenæan vases found in this cavern, and if we could have spent a longer time there, I might have hoped to discover altars and vases consecrated to maternity, or to illustrate from a medical point of view the statuettes representing pregnancy which $I$ had seen in Candia and Athens.

In front of the cavern, among the wild mint, I saw blue irises, much smaller than the Florentine variety, and on the mountain slopes wild pear trees made green spots between the greyish white of the olives. I lingered on the shore to watch the life of the sea. Long green seaweeds with spreading branches were rocked by the waves like a submerged field of grass, and to the corroded limestone rocks, which have the appearance of grey sponges, adhered the wide shield shaped shells of the tellina used by the fishermen for food. I tried to detach some where the waves were lapping their edges.

Before me the island of Dia rose from the blue sea, and

I Livy, i. 34 .

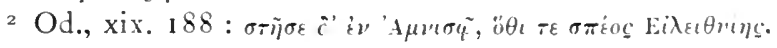


I remembered that Theseus and Ariadne rested there on the night when they fled from Knossos.

Greek authors agree that Venus was one of the first divinities to take shape in mythology. Herodotus says ${ }^{I}$ that the Scythians destroyed the most ancient temple of this goddess at Ascalon in Syria. Pausanias recalls another very ancient temple in the Island of Cythera, but for the study of preHellenic religions it may suffice to mention the temple of Venus on Mount Eryx, near Trapani, which tradition connects with the founding of Rome. The Elymi had left Troy (according to Thucydides) when it was destroyed, and had come to Eryx. Another and more ancient legend relates that Hercules slew Eryx, king of the Elymi, to punish him for the theft of a bull, and afterwards journeyed to the famous "Columns" at Gibraltar. In the legend of Hercules events are confused which happened in Crete and Phœnicia. The region of Sicily, opposite Lilybæum, was dwelt in by peoples who came from the eastern coast of the Mediterranean before the Phœnicians had migrated and before the Rhapsodes had begun to sing the Homeric poems. Hence, if the journey of Æneas is a fact, he only brought new settlers from the Troad to join the original colonies.

Diodorus Siculus says ${ }^{2}$ that there was a great temple of Venus on the Acropolis of Eryx, and that Eneas, as son of Venus, brought many gifts to the temple. Some have concluded, solely on the evidence of this ancient temple of Venus, that the Elymi were Phœnicians, but the evidence is insufficient. We know, however, that Cretans came to Eryx, and the religion of Venus flourished in Crete several millenniums before the Phœnicians began to emigrate to Italy. As in geological strata we can study extinct flora and fauna, so from the excavations in Crete and in Greek lands were brought to light the primitive forms which lie at the base of Hellenic mythology and which so strongly influenced the psychology and philosophy of Europe. Religions in their origins illustrate the synthesis of primary abstractions and the growth of conceptions from the phenomena

$$
\text { I Herod., i. 105. } 2 \text { Diod. Sic., iv. } 83 .
$$


of matter, from the struggle for life and from the effects of the passions, for religion is the conscience of the people and is renewed and modified with the race and its environment. The idea of Nature as a mother superior to all the other divinities came (says Plutarch) from Crete.

It is impossible to state with certainty what were the cosmological ideas of the Aryans, but among the early Mediterranean races Creative Nature is the first link in the chain of sacred images and ideas. Here the study of Woman in religion is important, because (as I shall show in more detail later) we are in a world not affected by the Aryans and we are dealing with a religion which developed in Mediterranean lands independently of the Indo-Germanic race. Here we can trace the steps by which pre-Hellenic minds approached the sphere of philosophy, here we behold the fine limpid source whence arose the river of science to fertilise the world. In this embryo of philosophic thought we observe that the Origin of Life was the problem that held the mind of Hellas in its infancy.

The two really historic races (to use an expression of Renan) were the Semitic and the Mediterranean. The first gives us by means of the Bible the grounds of faith, the second, by means of excavations, the rites of primitive worship. The Mediterranean race obtained supremacy over the Semitic because it established a more intimate relation between philosophic thought and the cosmic forces, and was better disposed towards the impulses of seductive nature and the needs of the human spirit. Instead of a severe and rigid theocracy, woman appears as the mediator between man and the occult powers. Priestesses are mothers and maidens who initiate the Greek race into the religion of beauty. The images of the Ægean prove that Ægean religion was allied to natural phenomena, inspired by admiration of the great mystery of life and instinct with the germs of progress for generations to come.

Venus Urania was the protector of chaste love, the deity of maidens, and of maternal affection. In Athens, on the fourth day of each month, young men and maidens met to honour her 
with sacrifices. In later times the cultus of Venus became sensual and corrupt, as at Colias. ${ }^{1}$

Venus Urania is not derived from the Phœnician Astarte. The Greeks called her "Aphrodite" ("gleaming in the foam "), the Latins "Venus," because all things come from her (quod per eam omnia proveniant). Lucretius, that scourge of religion who cast down the gods of Olympos, begins his poem with a hymn to Venus, the most beautiful ever written, and ends it with an Invocation to Nature.

\section{VI.}

The preponderance of female figures in religious functions, and the fact that the images are almost exclusively feminine, lead us to suppose that in the Minoan age woman held an important and influential position in religion and in the family. Herodotus writes: " When strife arose between the sons of Europa, Sarpedon, and Minos, contending for chieftainship, and Minos had the upper hand, Sarpedon broke away from Crete with his followers, and they, thus separated from their native land, crossed over to Asia (halting at Milia), where in process of time they changed their original name and called themselves Lici." Herodotus, having thus acknowledged that the Lici were of Cretan origin, adds: "They are distinguished not by the name of their father, but by that of their mother."

Polybius says the same of the Locri, and we know that among the Etruscans relationship descended in the female line. Tacitus, describing the customs of the Germans, says : " "They are as closely attached to their sisters' sons as they are to their own."

This preference given to the sons of a sister, added to the fact which Cæsar records-viz., that polyandry existed among the ancient Britons-makes it probable that the Indo Germani, too, traced descent in the female line. In the ancient Hindoo Epic, the Mahabharata, it is related that a princess was wife of

$$
\text { I Strabo, 373. 2 Herod., i. I73. } 3 \text { "Germania," xx. }
$$


five brothers at a time, and Max Müller accepts the probability that the Aryan race passed through that immature stage of civilisation in which woman has the supremacy. About forty years ago Bachofen published "I)as Mutterrecht." In this treatise he cites myth, tradition, and history in support of the view that matriarchal society has always preceded patriarchal. This is not the place to discuss the problem,' but for the interpretation of the monuments of Crete the evidence of Herodotus suffices.

Instances collected by McLellan and Lubbock prove that to-day inheritance in the female line is the rule in Africa, Last and West, in Circassia, Hindustan, Tartary, Siberia, China, and Australia, and was the rule among the American Indians.

Herbert Spencer, in his "Principles of Sociology," 2 maintains that in societies where promiscuity is the custom a habit of tracing kinship through the mother rather than through the father must arise, because the connection between mother and child is always certain, whereas the connection between father and child would sometimes be only inferable.

But the problem is much more complex. From the physiological point of view it is worth noting that the matriarchal system, though subject to serious defects and though rumning counter in some respects to modern civilisation, did not prevent the population of Crete from multiplying, expanding their power, and developing their intellect to a very high degree. If we find in the Minoan age traces of a more primitive condition such as still exists in uncivilised races, this only proves that human nature in like conditions produces like phenomena.

The evolution of the family establishes a régime suited to the needs of civilised society. Wherever the institution of marriage does not work under fixed and acknowledged rules, wherever conjugal conditions are vague and incoherent, there we find that the father is not considered as the chief factor in descent.

I V. Westermarck, "The History of Human Marriage," ch. v., London, 1904, and Cosentini, "La Sociologie génétique," Alcan, 1905.

2 Part iii. ch. v. 


\section{VII.}

A group of statuettes, found by Mr. Dawkins ${ }^{\mathrm{I}}$ at Palaikastro (Fig. I 36), representing a dance ${ }^{2}$ round a central figure, is variously interpreted. Mr. Dawkins thinks the female figure in the centre is the "Snake Goddess." In my opinion it represents a woman playing the lyre, and I am fortified in this opinion by the discoveries at Hagia Triada, which I discuss in Chapter XV. The object supported by her left hand corresponds in form to the Mycenæan cetra or lyre, and it is held in the usual way, while the right hand touches the chords.

The doves in front, with their wings in the posture of alighting on the earth, are sufficient in themselves to prove a religious function. The women round the player are in the act of dancing the so called "arm-in-arm" dance, which is popular to the present day.

In the Homeric poems the dove living in the rocks is often spoken of. This is the Columba livia, or wild pigeon, from which all varieties of the domestic pigeon are descended. The "peleja" is only cited as an example of timidity and swiftness. When Hector flees before Achilles the poet compares him to a dove pursued by a sparrow-hawk. 3

The discoveries in Crete ought to abolish those erroneous notions as to the migrations of the dove which have been held by some savants. Victor Hehn, one of the greatest authorities on the historical study of animals and plants and well versed in the knowledge of ancient literature, says 4 in his celebrated book that, after carefully studying the Homeric poems and all the ancient sources, he has arrived at the conclusion that the domestic dove arrived in Greece from Syria at the beginning of the fifth century B.c.

I Dawkins, "Excavations at Palaikastro," iii., Amnual of the British School at Athens, No. x. p. $2 \mathrm{I} 7$.

2 The statuettes are a little over $10 \mathrm{~cm}$. high.

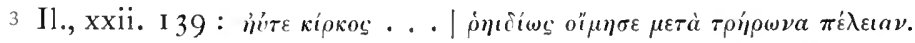

4 V. Hehn, "Kulturpflanzen und Hausthiere," 7th ed., p. 34t. 
Against this statement, founded on quotations from many Greek authors, we have the gold figures found by Schliemann in the tombs at Mycenx, representing nude women with doves on their heads and arms, fine gold-leaf ornaments (also from Mycenx) representing altars and doves, and a Mycenxan ivory

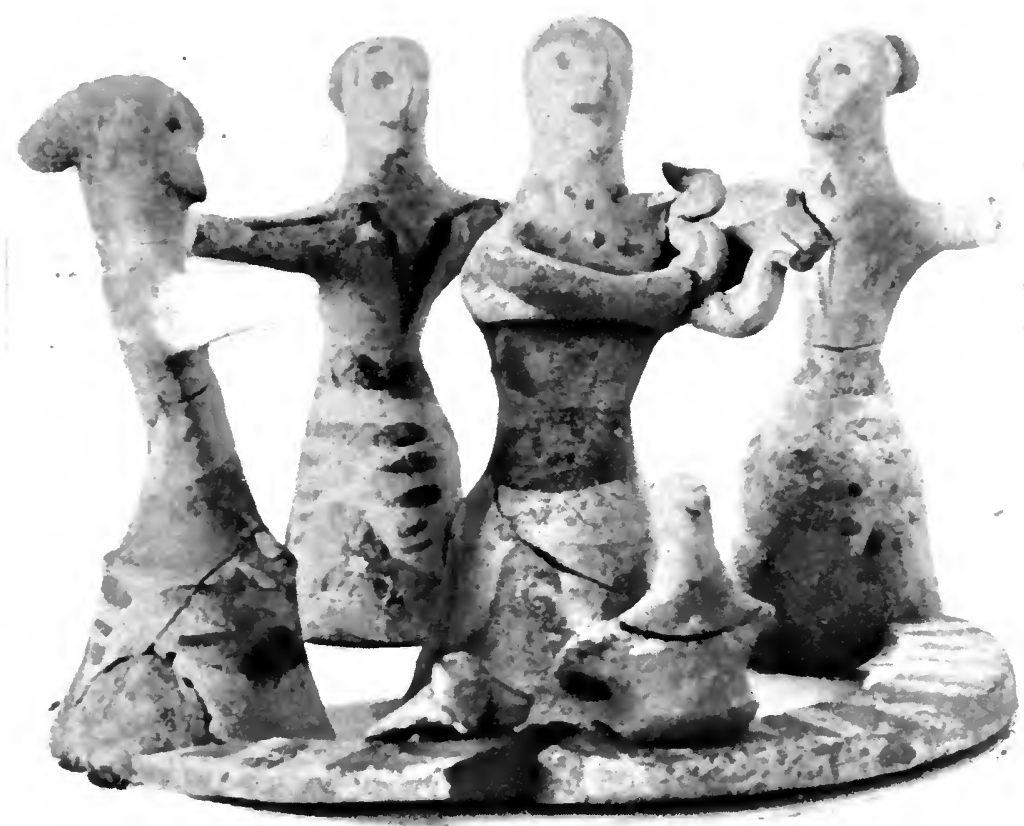

FIG. I36.-TERRACOTTA GROCP FOCND AT PALAIKASTRO BY DR. DAWKINS.

mirror-handle with carved doves, which is described by Tsountas and Manatt. ${ }^{\mathrm{I}}$

We now know that the domestic dove was common in Greece at least fifteen centuries before our era. At Koumasa, together with the ceramic work of the primitive Minoan epoch, there was found an ivory seal contemporary with the VIth ז “'The Mycenæan Age," p. I8-. 
Egyptian Dynasty. The incised design represents a dove holding a young bird under its wing. On a vase of terracotta is a dove of exquisite workmanship. I Fig. I37, a terracotta discovered by Dr. Evans at Knossos, ${ }^{2}$ shows doves perched on columns which resemble those of the Lion gate at Mycenæ. The three columns are each surmounted by a capital and round logs indicating the roof-beams. On these logs the doves are placed. Each column has a round base and they all stand on a common square plinth. The colouring is black, red, and white, like the pottery found in the district, which belongs to the third period of middle Minoan age. I have already explained, with the aid of evidence collected by Dr. Evans, how the emblem of the dove was brought into Greece from Crete. A cup from Zakro shows the doves perched fearlessly on the edge, 3 as if tame, and recalls the cup given to Achilles by Hekamede.

\section{VIII.}

Excavations in Crete have shown that the dove was domesticated there at least two thousand years before our era. On Kamares vases belonging to the second period of the middle Minoan age we find doves painted on a black ware with delicate white ornamentation. At Palaikastro the doves are painted in white, only beak and eyes are black. In a design belonging to the third period of the final Minoan age a dove is marked with black and white lines on the neck and wings. In the case of pigeons identification of species by colour of the design would be impossible because there must have been many varieties.

It was natural that the gentle dove with its poetic note should be worshipped by the ancients and regarded with veneration as a sacred symbol by the Christians. The cock and hen do not appear on the most ancient monuments of Minoan

I Hogarth, Fournal of Hellenic Studies, vol. xvii. p. 3 Io.

2 A. Evans, "The Palace of Knossos," p. 29, 1902.

3 Black doves occur on the sarcophagus of Hagia Triada and also at Knossos (Evans, 1902). 
art. The cock is often mentioned in the Bible, ${ }^{1}$ but in Homer neither fowls nor eggs are referred to. ${ }^{2}$

The outline of these birds is so characteristic that if they had existed Cretan artists would no doubt have drawn then. We may therefore be sure that fowls were unknown in Crete up to the end of the Minoan age.

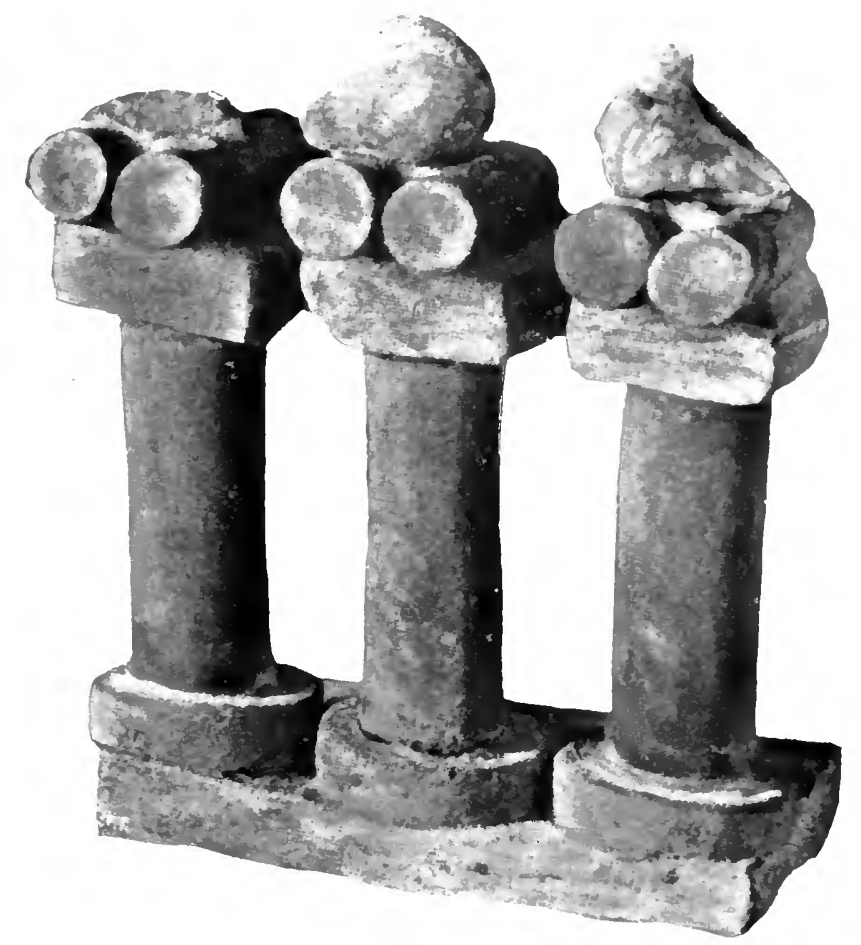

FlG. I37.-THRRACOTTA FOCYI AT KNOSSOS BL IR. EVANS.

Three columns similar to those of the Lion Gate of Mycenes. A dove is perched on each capital.

Doves have an instinctive fear of the polecat, and if they see one near the dovecotes they fly away, and sometimes do not return for days. The ferocity of the polecat and the havoc it makes in a dovecote are almost incredible, for it kills many more

${ }^{1}$ Isa. xii. 17, Prov. xxx. 31, Job xxxviii. 36.

2 Vide "Batrachomyomachia," I 90. 
birds than it can eat. For this reason the Mycenæan people sacrificed this enemy of doves to the goddess in the dove temple.

Tame doves must have been known in Greece before the time of Homer. Isaiah speaks of those who " return like doves to their windows." I

When the Homeric poems were composed, carrier pigeons were probably known in Greece. Doves are employed in carrying Ambrosia to Zeus. ${ }^{2}$ Elian says 3 that in the sixth century B.c. doves were used for carrying messages. This would not fit in with Hehn's assertions, the less because doves must be thoroughly domesticated before they can be taught to carry messages.

Frequent as is the occurrence of the sacred dove in Crete, the Phœnician image of Astarte with doves does not appear. The dove is the emblem of love, and as such must be closely connected with the cultus of divinities of fruitfulness, and these divinities in Greek lands are probably of Pelasgic, not Phœnician origin. To derive the worship of Aphrodite in Sicily and Southern Italy from the worship of the Phœnician Astarte 4 is no longer possible, for we have seen that a nude divinity to whom doves are sacred appears in Crete and Mycena at a time when the Phœnicians had not been heard of - that is to say, many centuries before they had begun to trade by sea.5 This divinity precedes the individualised gods, and represents the root power of life, mysterious, piercing, and compelling, of all human passions the most irresistible.

I Isa. $1 x .8$.

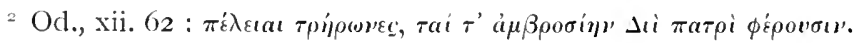

3 Var. hist., ix. 2.

4 Bérard, "Les Phéniciens et l'Odyssée," ii. p. $3^{8} 3$.

5 Pais, "Storia della Sicilia," p. 600. According to Orsi nothing Phonician of a date earlier than the eighth century B.c. has ever been found in Sicily, while early Mycenæan bronze and pottery is quite common. Orsi, Bullettino di paletnologia, xiii. p. I 3 . 


\section{CHAPTER XV}

COOKERY IN POETRY AND REAL LIFE

I.

TO regard Homer as a historian is a serious mistake. It 1 was Gladstone's idea that the great number of legends introduced by the bard into the Iliad can only be explained on the supposition that they were historical narratives woven into the poem in order that they might be preserved and remembered. Archæological research and the discoveries in Crete show the error of this view.

The Homeric poems are about as trustworthy sources for information on institutions, daily life, and dress as the "Chansons de Geste" and the romances of the Round Table. The Greek epic and the French were written under conditions not very diverse, and in both the origins are obscure. We do not know when the Greek rhapsodes or the French bards began to sing the deeds of their heroes at festivals and banquets. Charlemagne, like Peisistratos, collected the rhapsodes' songs, to write by their aid the history of his people. The correspondence is complete, and, therefore, we ought not to rely on historical accuracy in the Homeric poems any more then we should do in the "Chanson de Roland," or in the cycles of gesta of imaginary heroes, whose chivalrous exploits in the wars between Christian and Mussulman were amplified and related as miraculous in legend and song.

The poets who made Charlemagne fight under the walls of 
Jerusalem cared little for historical or chronological exactitude, and we may say the same of the Homeric bards. The fact that the most ancient genealogies in Homer go back to the seventh generation and cover a space of two hundred years ought to warn us against expecting great accuracy. When we read the Homeric poems it is difficult to understand how people ate, and this is natural enough, for the Muses are neither housekeepers nor cooks.

The Homeric poems were recited at banquets where the guests were enthusiastic for war or adventures at sea, and the poet who, lyre in hand, declaimed the battles of Troy or the exploits of Odysseus did not stint the good cheer on the table. Abundance is the dominant characteristic of the Homeric kitchen. At the beginning of the Iliad, Agamemnon kills a fat ox five years old for eight persons. It is quartered, roasted on a spit, and eaten to the accompaniment of much wine. The popular singers who worked up the epic material described a world different from reality, but adapted, in their opinion, to the deeds of their heroes, and they derived their notions on the subject partly from records and partly from traditions of a bygone time.

\section{II.}

Cooking in Homer is monotonous, because no one eats anything but roast meat. Achilles, the favourite hero of the Iliad, offers to his guests, even on solemn occasions, nothing but roast flesh, and so do all the others.

Cleanliness at meals left much to be desired. The princes who aspire to the hand of Penelope gormandise like peasants. I looked in vain for a spit among the kitchen utensils of the Bronze Age, nor could I identify any spear-shaped metal implement like those in Etruria. Hence I am inclined to think that meat was roasted on wooden spits, and to suspect that the constant twirling of the spit may be an exaggeration of the poet. We shall soon see that the Mycenæan kitchen excelled all others in the preparation of meat by boiling and stewing. The bards 
do not wish to idealise the table of their heroes, for they make them eat garlic and onion on occasion. Nor are the princes afraid of strong flavours. Curly-haired Hekamede "placed on the board a copper vessel with fresh honey, and onion to give zest to the wine." I

In the Homeric poems two extremes are shown, dainty food and the ordinary fare which would not be to our taste. Odysseus eats a black pudding full of blood and fat. 2 It seems that tripe, such as is still eaten by the poor, was usually roasted, for Odysseus turns and tosses on his bed like a piece of tripe that a man roasts at a fire. 3

Thus the Homeric poets related the heroes' acts and customs according to their own fancy, and more particularly to please the fancy of their hearers.

There is praiseworthy moderation in drinking. Rabelais would never have thought of making his characters water their wine, for their tremendous appetites were to prove them more than human. In the Homeric poems wine is always mixed with water. The first duty of the servants who prepare the dinner is to mix the wine, and when the sailors land on the beach they go straight to the fountain to fetch water for the purpose. Perhaps there is some exaggeration even here. Odysseus receives from Maro a wine so potent that it must be diluted with twenty measures of water.t

The heroes of the Homeric poems were better acquainted with the physiological action of alcohol than most people are to-day. They knew that wine does not give strength. Hector refuses wine, lest his courage should slumber at the critical moment.j Wine was also diluted with milk or honey. I give the recipe for a refreshing beverage taken from the Iliad, but I think few will care to try it: "Take some effervescing wine

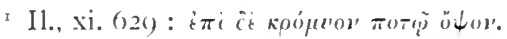

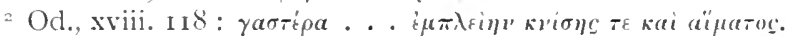

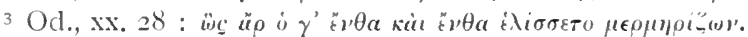

* Od., ix. 204 : ở

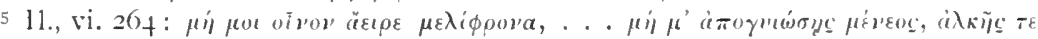

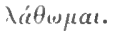


and beat up in it some curdled goat's milk, strew over it lightly a little white flour, serve cold." I

\section{III.}

The Homeric poems do not mention gardens or orchards, for the descriptions of the great orchard near the palace of Alkinoüs and of Laertes' garden are supposed to be very late additions, perhaps of the sixth century B.c. ${ }^{2}$ The lliad and the Odyssey both refer to the wild fig, but edible figs are only mentioned in the later interpolations of the poem, and then only exceptionally. Andromache says to Hector,3 "Assemble thy warriors at the wild fig-tree," and Odysseus saves himself from Scylla's whirlpool by clinging to a wild fig-tree. Hehn, celebrated for his philological studies on the diffusion of animals and plants among the ancient peoples, concludes that when the "lays" of the Iliad were composed the fig was not known in Asia Minor or the Islands, far less in Greece, and that the cultivation of the fig began about the time the Odyssey was written.4

Hesiod does not speak of the fig. Cretan discoveries have, however, shown us that this tree was known, painted, and represented in relief perhaps a thousand years before the time of Homer. I have seen the carbonised figs and held them in my hand. I could recognise the ridges and irregularities of the fresh ripe fruit ("fichi dottati," as they are called in Tuscany), with its wrinkled skin.

On the sarcophagus of Hagia Triada is painted a basket of fruit, which a man raises in his arms in the act of sacrifice. It is a pleasure to see these beautiful juicy fruits. In Homer no one eats fruit, and some have assumed that in Homeric times the climate was too cold to ripen it. This must be a mistake, for the apple is known to Homer, and the expression "golden yellow

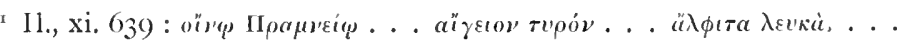

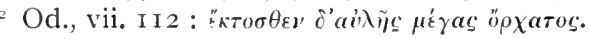

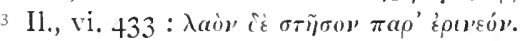

$+V$. Hehn, "Kulturpflanzen und Hausthiere," vii. ed. p. 95. 
as a ripe apple" is used. The poets simply neglected to mention fruits on the table.

Hippocrates, in speaking of diet, gives an ample list of the vegetables and fruit which were eaten in his time in Greece, and this corresponds very nearly with the plants and trees found in gardens to-day. Horticulture cannot change radically in four hundred years.

Schlienann found beans in the ruins of Troy. Virchow describes one variety. At Heraclea vases full of lentils were found ; in fact, putting history aside, much might be written on prehistoric botany. This year when I visited Dr. Pernier's excavations I picked up a handful of charred peas among the burnt remains. They were black, but the form was exactly preserved. Beans and corn were found at Hagia Triada in large jars.

As Schiller and Humboldt have noticed, ${ }^{\mathrm{I}}$ ancient Greek poets had no feeling for nature and found no pleasure in looking at the beauties of a landscape. In this they resembled peasants and children. They were impressed chiefly by the sea and animals. It would be useless to look for picturesque descriptions of plant life in Homer. Flowers are hardly mentioned at all, and more rarely with an adjective that defines their colour.

\section{IV.}

In the house of Odysseus there were twelve millstones, i.e., small ones, for grinding corn by hand. At Phæstos I found many of these stones with which the maidens ground the golden grain. 2

In the Egyptian monuments and in the lake dwellings of Italy, similar stones have been found. Those of Phastos are hollowed like a shell, and worked down on the outside to make them thin and easy to carry. Grindstones, with a conical cavity in which a second stone spun round, were a later invention.

× "Kosmos," i.

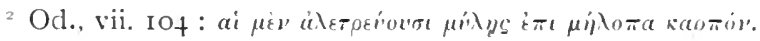


On Roman monuments this kind of handmill, with the slaves round it, is often represented.

Although a seafaring race cannot live luxuriously, the poets must have exaggerated the simplicity of the fare taken on board to provision the ship for a voyage. When Telemachus sailed to Sparta by way of Pylos, to seek tidings of his father, his stores for several days at sea consisted only of wine and flour.

It is usually supposed that fish was not eaten, because it is not mentioned as forming part of a banquet. The companions of Odysseus, delayed in the Straits of Messina for a month by contrary winds, only fished and hunted when driven by hunger. ${ }^{\mathrm{I}}$

The Homeric poems contain no treatise on cooking, but the simile of the fisherman in the Odyssey (book xii.) shows that the occupation of fishing was known at the time.

M. Bérard thinks that when Odysseus passed the Strait of Messina, the sword-fish was caught, as it is to-day, for Odysseus stands with his spear on the prow in the same way that modern fishermen do.

It is evident that in Minoan times fish (preferably the best varieties) were used as food. The splendid mullet portrayed on a fresco of Knossos would worthily decorate a modern dining-room. On vases and seals a frequent pictorial motive is the net containing fish. Mr. Evans found a gold fish of good workmanship, which was probably meant for a pendant. Thus, instead of assuming that fish were not eaten in Homeric times, we may rather suppose that they were a common article of food, for we know that in the fifth century в.с. the Athenians considered fish a delicacy. To show that as early as Mycenæan times large fish were in demand, I reproduce (slightly enlarged) one of the seals in the Museum at Candia which represents two tunny fish (Fig. I 38 ).

Sea urchins and other shell-fish appear on paintings and seals, and this seems to prove that they formed part of everyday fare.

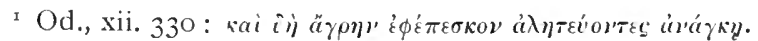


Among the remains at Phrstos I found a piece of a sea urchin of considerable size.

Game is not spoken of in Homer, but we may be sure that this was an accidental omission, for the Greeks were skilful hunters in the Neolithic period before the dawn of history. Boars' tusks, horns of stag and chamois, and bones of hares are abundantly found in the excavations.

\section{V.}

In the Homeric poems the hearth is the centre of the house, even in a royal palace. In the dining-hall are vases of gold, basins of silver, whitest linen, doors and doorposts of precious metals, the ceiling is adorned with blue enamel, and yet we might think that these riches would be spoilt by the smoke and smell of cooking, for the poems do not refer to a separate kitchen.

Odysseus prepares for the slaughter of the suitors by

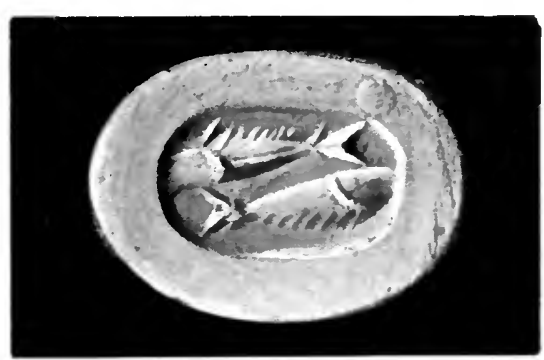

FIG. 138.-SEAL IN THE MLSECM AT CANDIA. telling Telemachus to carry their weapons to the upper rooms, and, if the suitors ask for them, to say, "Out of the smoke I have laid them by-they are wholly marred, so mightily hath passed upon them the vapour of fire." 1

Even if we suppose the house of Odysseus of modest proportions, surely Hector's palace, with its splendid porticoes and its fifty bedchambers, must have contained a kitchen.

This year Dr. Pernier found a Minoan hearth or fireplace (Fig. 139), the first as yet discovered, but, contrary to Homeric tradition, it is not in the middle of the hall. It resembles a modern fireplace and stands in one corner of a room in the

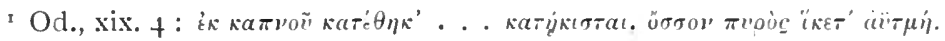




\section{PALACES OF CRETE AND THEIR BUILDERS}

primitive palace at Phæstos. A stone with a pointed end is placed against the wall. In front of this are two lateral stones with a space between them, about Io centimetres deep, in which

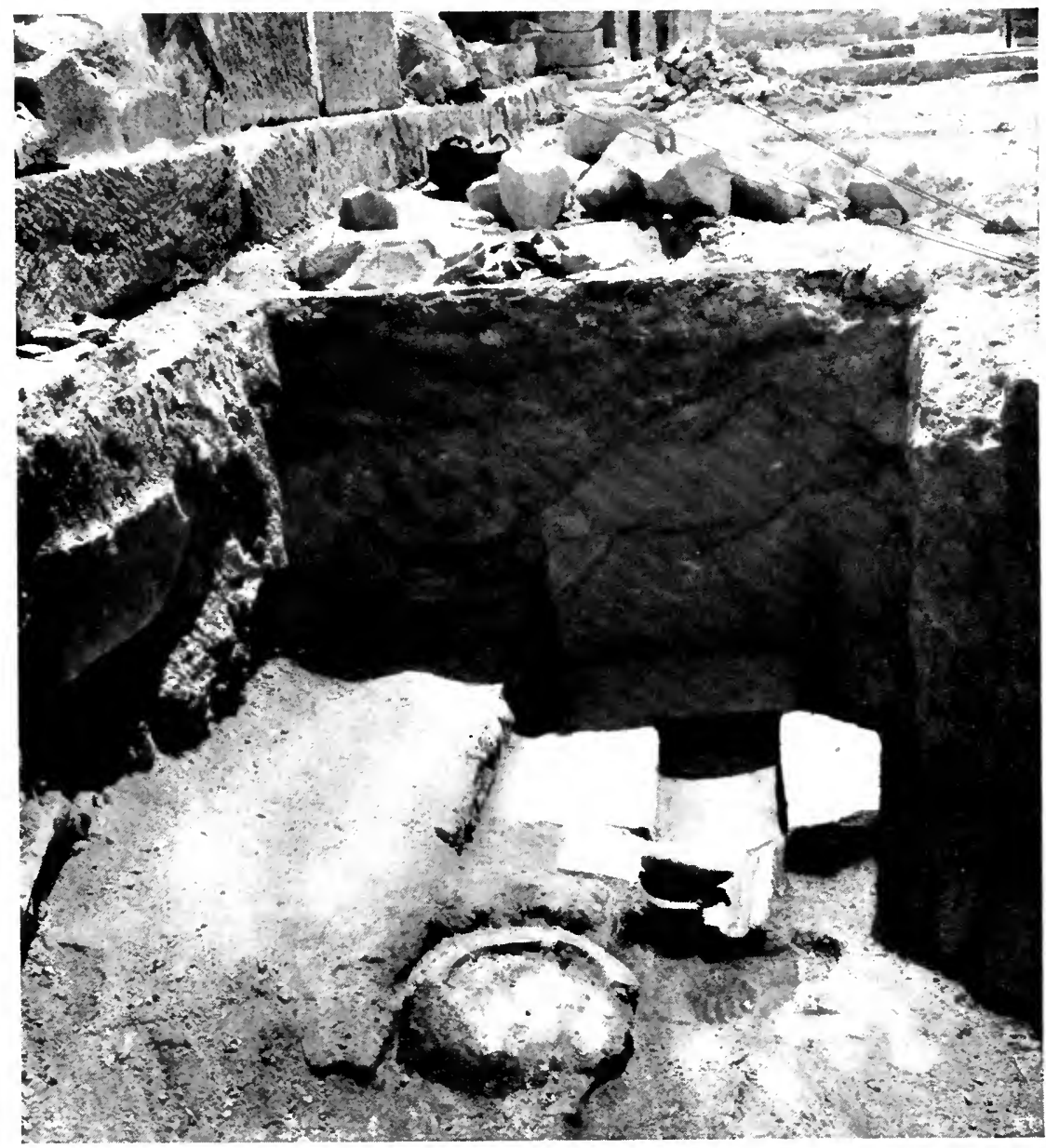

FIG. I39.- WIREPLACE FOCND IN THE MOST ANCIENT PALACE AT PHASTOS BY DR. PERNIER.

logs were burned. A large stone was used instead of "dogs" to keep the wood up. Inside the hearth is worn down at three places, where, evidently, saucepans were set. A small gutter-shaped channel served for the passage of a current of 
air to feed the flame. The sides of the cavity were covered with ancient soot, thick below and growing gradually thinner to the top.

VI.

Considering the number of slaves and soldiers it seems strange that Odysseus and Patroklos should have to do their

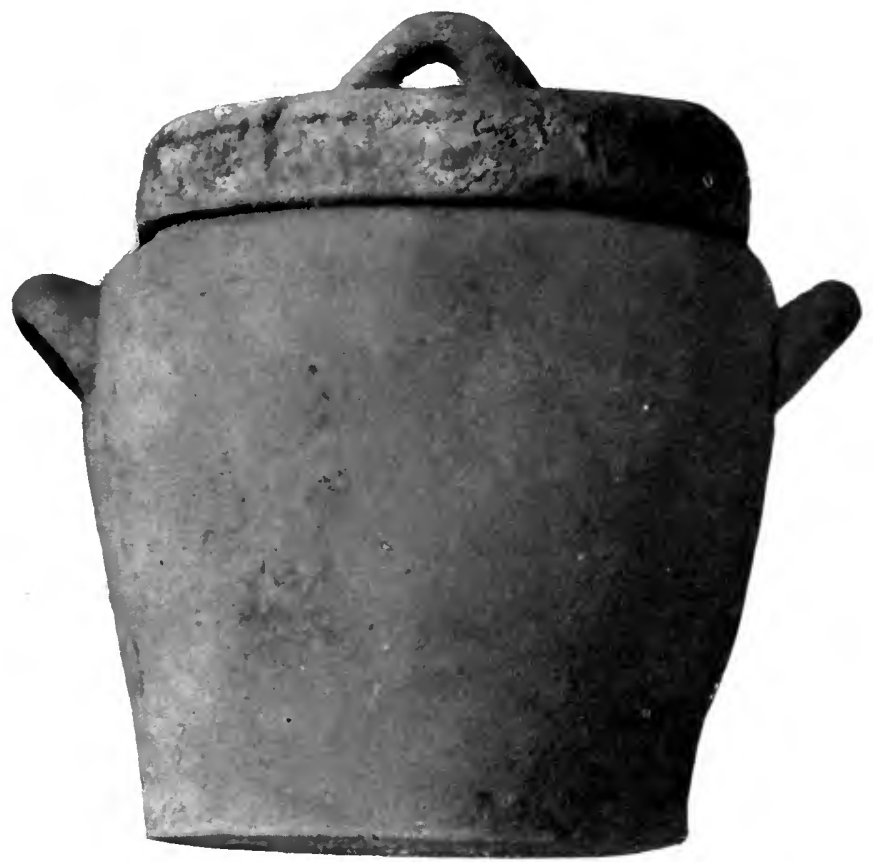

FIG. I fO.-LARGE EARTHEN COCKING POT IN THE MUSEUN AT CANDIA.

own cooking. It was a fancy of the Homeric poets to show that even a king could cook. When Agamemnon sent a special embassy to appease Achilles, Patroklos ${ }^{\mathrm{I}}$ set a great cauldron on the blazing fire and put in it the fat flanks of a sheep and a kid and the chine of a great hog. When the meat had thus been made tender, Achilles cut it, stuck it on spits and roasted

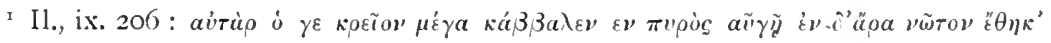
bios kai miovoc aíós. 
it. This dish was, therefore, stewed and then finished before the fire.

There is no information about soup or boiled meat, although pots for boiling were very common in Mycenæan times. Terracotta stewpans with lids have been found in numbers. I give a large one as an example (Fig. 140).

Minoan kitchen apparatus deserves special study, as it is full of ingenious contrivances from which we might profit. The lids, for instance, show that it is a mistake to suppose that flesh was

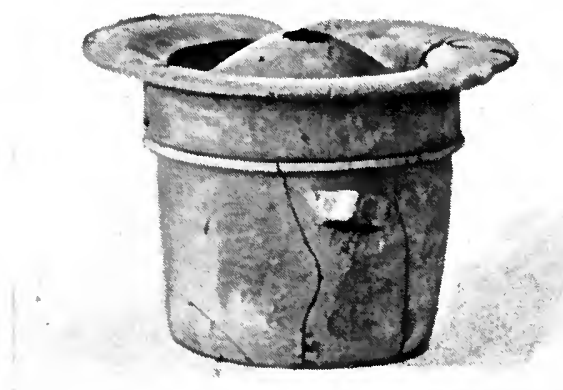

FIG. IfI.-STEWPAN WITH CONDENSING LID.

only eaten roasted. On the contrary, the art of boiling was better understood than among us to-day.

The great thickness of the lid is very striking, and is specially adapted for slow boiling. When the pot begins to boil the lid may shake and the contents boil over. To prevent these accidents the Mycenæans invented a condensing lid, which is seen in Fig. $1+1$. They are large and small, but all made on the same system. Fig. I +2 illustrates the lid of a saucepan which I found among the fragments of pottery in the most ancient palace at Phæstos. The lid is shown as seen from above, from below, and in section. In an internal chamber, $b$, the vapour condenses, and it then falls back into the saucepan. On 
the top of the lid is a circular depression. This was probably filled with water, which would serve as a cooler by evaporating.

\section{VII.}

Bronze vessels have the most various forms. At Hagia Triada, in the Mycenæan villa, were found great cauldrons such as are used now by women for washing clothes and by
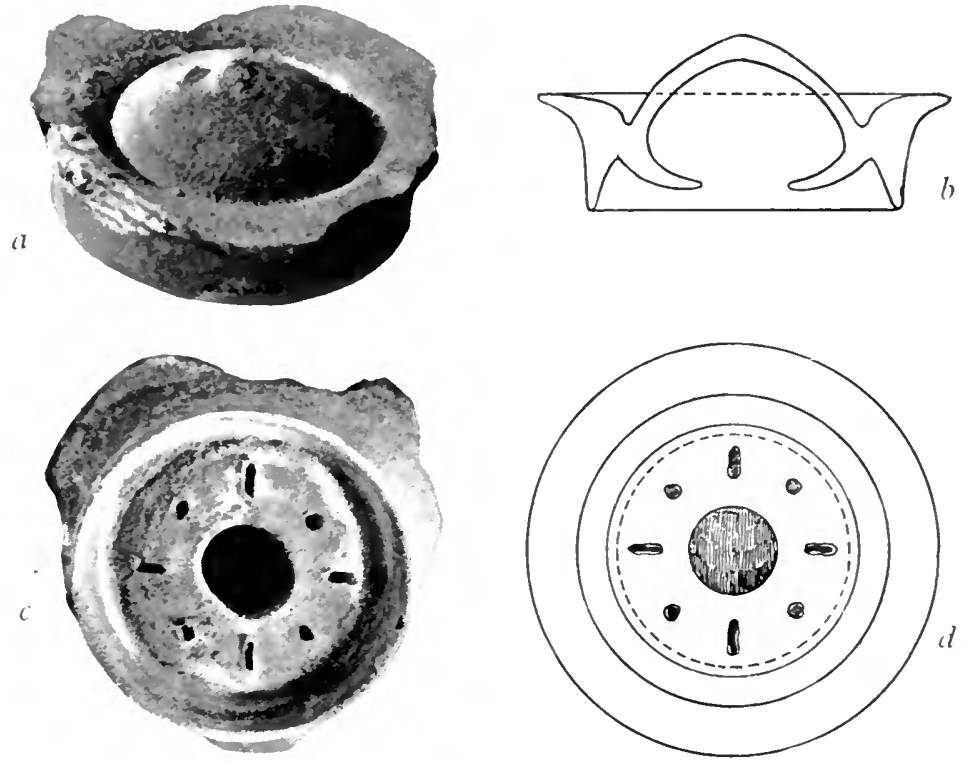

FIG. I $2 a, b, c, d$-LID OF A STEWPAN SEEX FRON ABONE, BELOW, AND IN SECTION.

shepherds for making cheese. Strange to say, no plates were found. The absence of small bronze spoons or anything in the shape of a fork makes it probable that in those times food was taken in the hand much oftener than it is now. There are lebetes, or kettles of copper, with three feet, which might have just come from one of our own kitchens. A lebes from Gournia (Fig. I +3) is exactly like the one found this year at Phæstos, which had lost two feet. The edge is well worked, 
and has a horizontal rim to support a lid.I To give a better idea of the kitchen utensils I reproduce some found in a tomb at Knossos ${ }^{2}$ (Fig. I 44).

A long corridor, one and a half metres wide, leads down to a mortuary chamber, in which these bronze utensils were found, placed as they are in the illustration. In front is the brazier of gesso still containing the remains of charred wood ; a lamp $(f)$ with the chain for attaching an extinguisher, and other vases in the form of hydriæ, amphoræ, basins and cups. At the right-

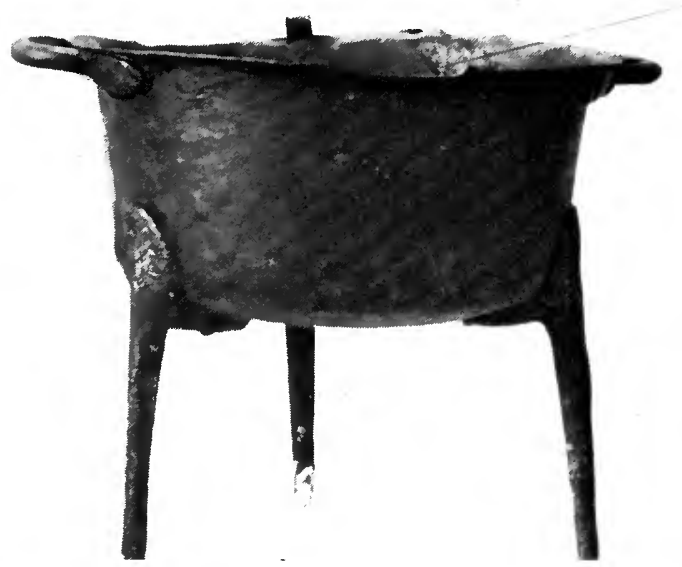

FIG. I43.-COPPER LEBES OR CAULDRON IN THE MUSEUM AT CANDIA.

hand corner, near the door, were found knives, razors, and fragments of a casket inlaid with ivory.

As early as the Neolithic period large spoons or ladles made of terracotta were used, probably only as ladles. One of the same kind is marked 0 in Fig. I 44.

I Diam. $27 \mathrm{~cm}$., depth $12 \mathrm{~cm}$. The chemical analysis shows 98.212 per cent. of copper, mixed with iron, lead, and sulphur. Zinc and tin are absent. I do not know whether the material of the vessels found by Evans in a tomb at Knossos (Fig. 144) has been analysed. Evans states that they are of bronze. vol. lix.

2 A. Evans, “The Prehistoric Tombs of Knossos," from Archeology, 


\section{VII.}

It would take too long to enumerate all the forms of saucepan used in the Minoan kitchen. Even a hasty examination showed me that there were a good many kinds of perforated receptacle for straining or filtering. At present we use hardly any such,

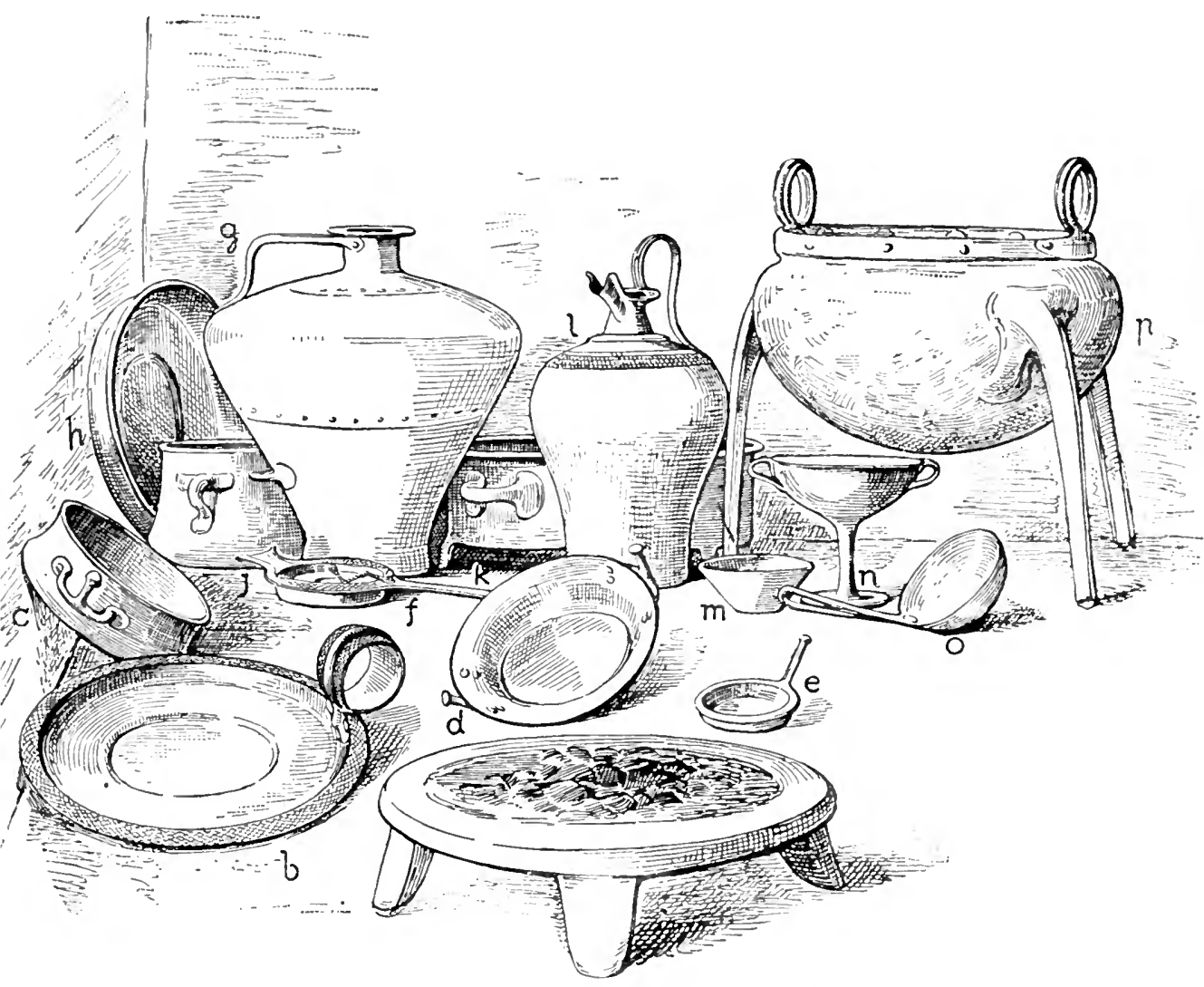

FIG. Iff.-BRONZE VESSELS FOLND IN A TOM13 AT KNOSSOS BY DR. LVANS.

except skimming spoons, frying baskets, soup and tea strainers. Tea and coffee being unknown in the Minoan age, infusions of salvia and other plants were made, to be drunk with honey. Perforated vessels were also used for straining the whey from the curd before making cheese or clotted milk. For carrying 
charcoal from one fireplace to another braziers of terracotta were employed (Fig. I $45 a$ ). The border of the brazier is turned over near the handle, so as to protect the hand from the glowing heat of the charcoal. Some of these, found in tombs, still held the remains of charcoal and ashes. Figure $\mathrm{I}+5^{b}$ shows

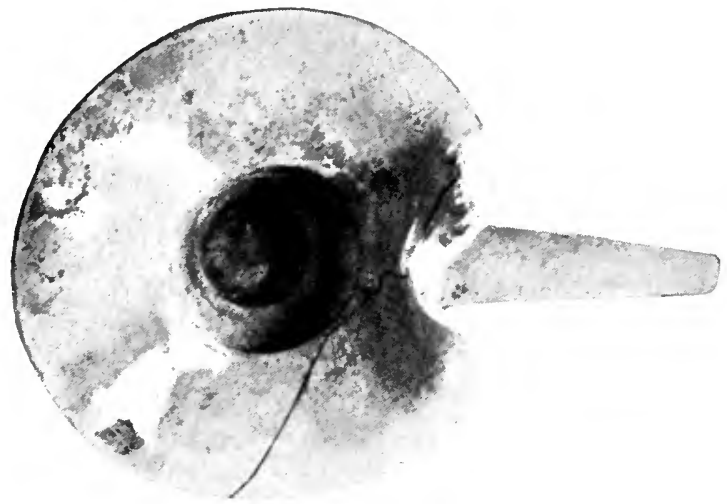

FIG. I $+5 a$.-TERRACOTTA SHOVEL FOR CARRYING LIGHTED CHARCOAL.

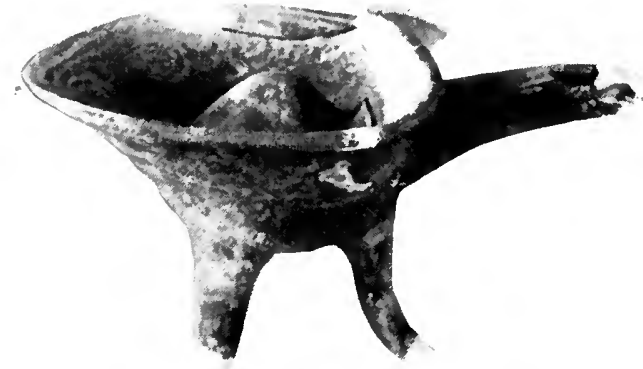

FIG. I 45 b. - CHARCOAL SHOVEL OF MIRE CONPLICATED SHAPE.

one of these braziers. It has a conical bulge upwards in the bottom, which forms a cavity underneath. This cavity communicates with the air by holes, which form a design like a triangle. Perhaps this more complicated vessel served as a cooler. Some, no doubt, were used for funeral ceremonies, and these were decorated with spirals. 
The vessel represented in Fig. I 46 , with a pierced bottom like a sieve, is worth studying. Mr. Dawkins calls it a "clay bread-pan." I A similar vase was found at Tiryns.2 I think it more likely that this belongs to a class of vessels used for making cheese or for straining various liquids. They are found in all sizes, from a small cup to a large sieve. Some elegant cups are in two divisions, the upper, perforated, probably meant for holding the leaves to make the infusion, the lower for drinking.

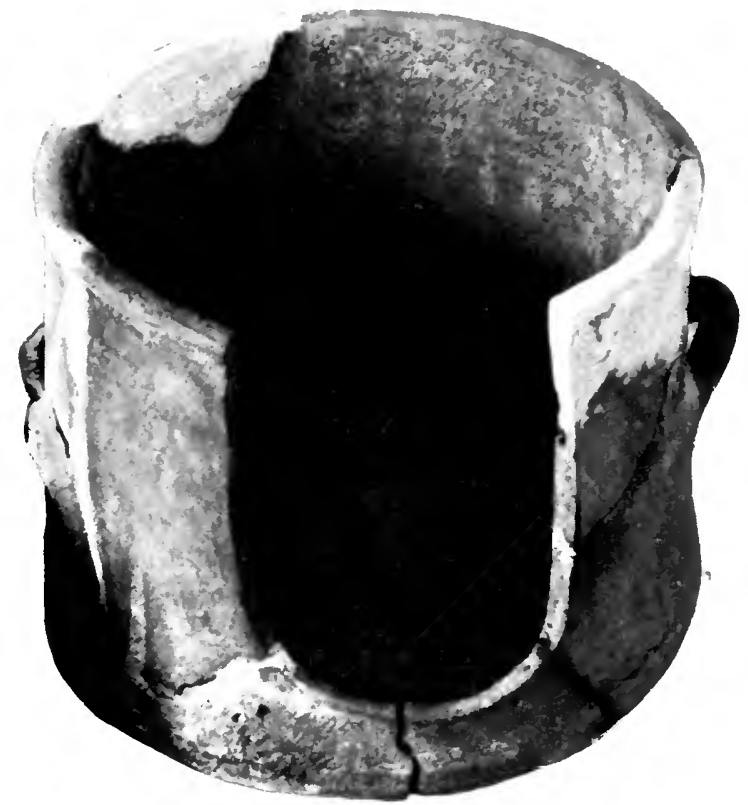

FlG. I 6.-LARGE TERRACOTTA VESSEL FOCXI) BY MR, DAWKAS.

Many kinds of milk products, such as cheeses and curds, must have been used for food in Minoan times, for forests were abundant and cattle rearing extensively practised. This is illustrated by a cup in which the potter has represented in relief a herd of more than one hundred cattle. Homer does not mention butter, but this omission is unimportant, for wherever

Annual of British School at Attens, ix. p. $32 \%$.

2 Schliemann, p. I 6 . 
milk is used butter must be known. Certain large perforated discs with designs on the surface may have been used for covering viands.

\section{IX.}

It is a great mistake to suppose, as some have done, that in Homeric times the olive was not cultivated in Greece, and that imported oil was only used for perfumery and for anointing the skin. This view is founded on the circumstance that in the Homeric poems oil lamps are not spoken of, and oil is only referred to as an aid to friction after the bath to increase the strength of the muscles. But as early as Minoan times olive oil was very abundant, and candles were used for lighting.

Hehn says that at the time the Homeric poems were written the olive tree was not cultivated in Greece, ${ }^{\mathrm{I}}$ and that the portions

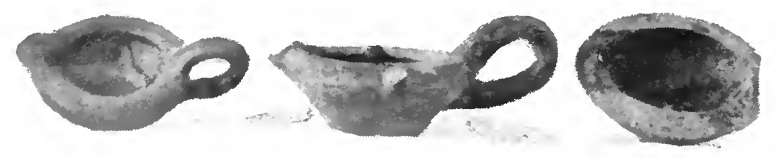

FIG. I47.-TERRACOTTA LAMPS.

of the poems in which the olive appears are intercalations of later date.

In speaking of lamps, as in the palace of Alkinoüs, the poet gives his imagination a loose rein." "Youths fashioned in gold, with flaming torches in their hands, giving light through the night to the feasters." These torches were great branches of resinous pine, and a slave stood ready to quench and change them, as we read in Sir Walter Scott's romances.

The poets evidently preferred this method of illumination, for we read that in the house of Penelope the women took turns to keep up the light, piling dry wood on the brazier.3 Homer only

I Op. cit., p. 105.

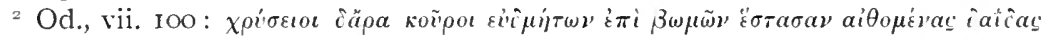

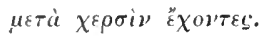

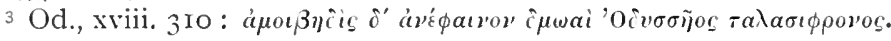


mentions a silver lamp, but there must have been many lamps made of terracotta, limestone, and steatite.

A peculiarity of the lamps found in the excavations is that most of them have an edge which supports the burnt wick. This proves that the lamps were allowed to burn till all the oil was consumed, and that there was such abundance of illumination that it was not usual to economise it. Besides small portable lamps in terracotta (Fig. I +7 ), there were others, more massive, in marble or steatite (Fig. I $f^{8}$ ), which were probably kept stationary.

The lamps themselves were decorative, as is evident from the artistic forms, similar to the one illustrated in Fig 149 .

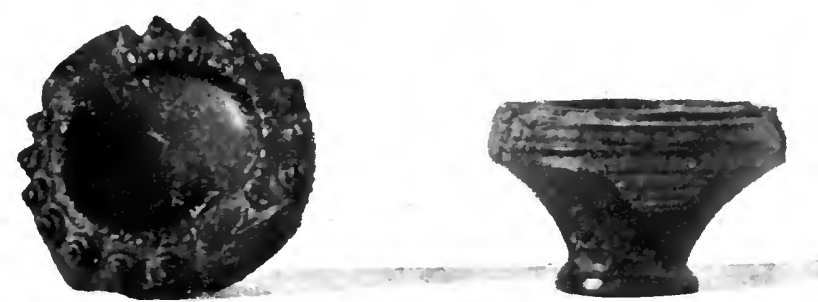

FIG. If S.-STEATITE LAMI'S (LARGER AND HLATLER THAN THE LAST).

Dr. Evans found at Knossos a large lamp made of the rosecoloured limestone found in the neighbourhood. The top is an imitation of an Egyptian capital with its lotus flowers and papyrus leaves. Its height is $50 \mathrm{~cm}$., and it belongs to the second period of the last Minoan age. The lamp shown in Fig. I 49 is of Spartan limestone, and bears a graceful conventional floral ornament. It was found at Palaikastro, and resembles the lamps still in situ in the villa at Hagia Triada.

Although among the great number of lamps found in Crete some are of Egyptian form, it is strange that lamps properly so called have not been found in Egyptian excavations. The rare 
examples to be seen in museums are standards a metre high, made of wood, supporting a small bronze saucer for oil, in which the wick burned. This type of lamp is quite different from the Mycenæan.

At Knossos some lamps were found intact, as they had been abandoned when the palace was burnt. One stood in the

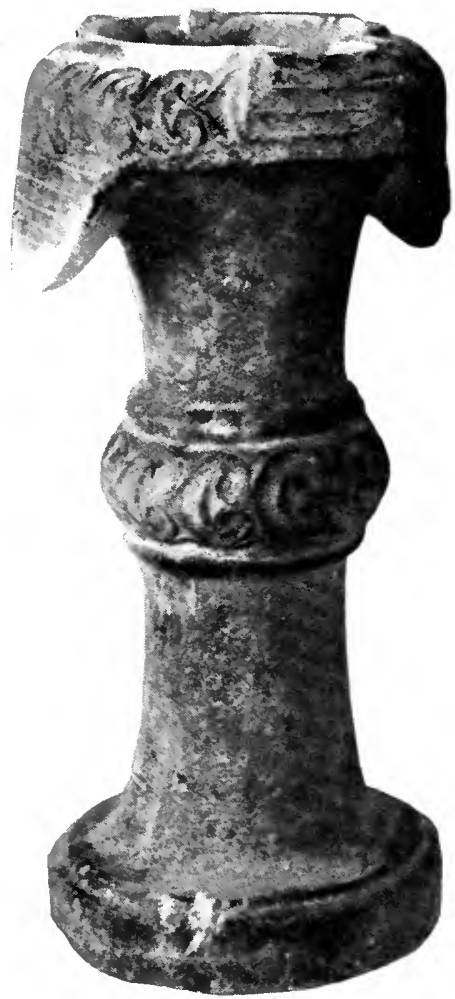

F1G. I49. - LAMIP OF SPARTAN LIMESTONE FOUND AT PALAIKASTRO. hall which Evans identifies as a tribunal. ${ }^{1}$ This circumstance is interesting as showing the political activity of the time, for state affairs were evidently discussed there by night as well as by day. It is a hall in the form of a basilica, with a tribune protected by a balustrade and approached by three steps. At the back of the tribune is a niche with a throne. The place for the public was below in front of the apse containing an exedra, and the judges sat on the platform behind the balustrade. In their architecture the Roman basilicas resemble this hall of the Minoan palace.

\section{$\mathrm{X}$.}

There was abundance of oil. Some lamps held a litre or two (Fig. I $50 a$ and $b$ ). As the oil was burned away its place was filled by water, and the wick was kept straight by a sniall flat projection of terracotta, near the opening of the lamp.

Dr. Evans discovered two oil presses at Knossos. The larger one is made of a slab of marble more than a metre wide. There

$$
\text { I “The Palace of Knossos," I 4+, } 1903 .
$$


is a large basin under it and a deep runnel for draining off the oil. Another press was found at the top of a hill a few leagues from Knossos.

As these presses are identical with those found in Tripoli it is clearly necessary that explorations should not be limited to Crete but should be extended to Lybia, whence new light may be

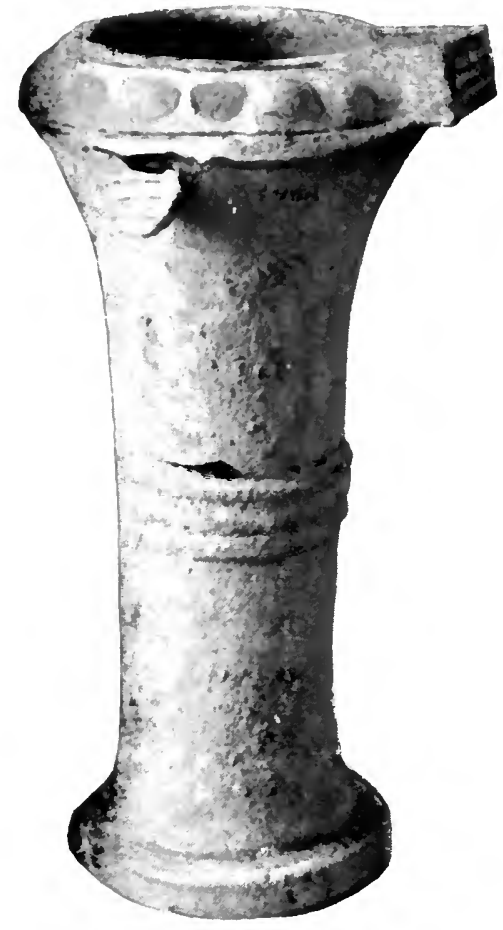

FIG. $150 \%$.

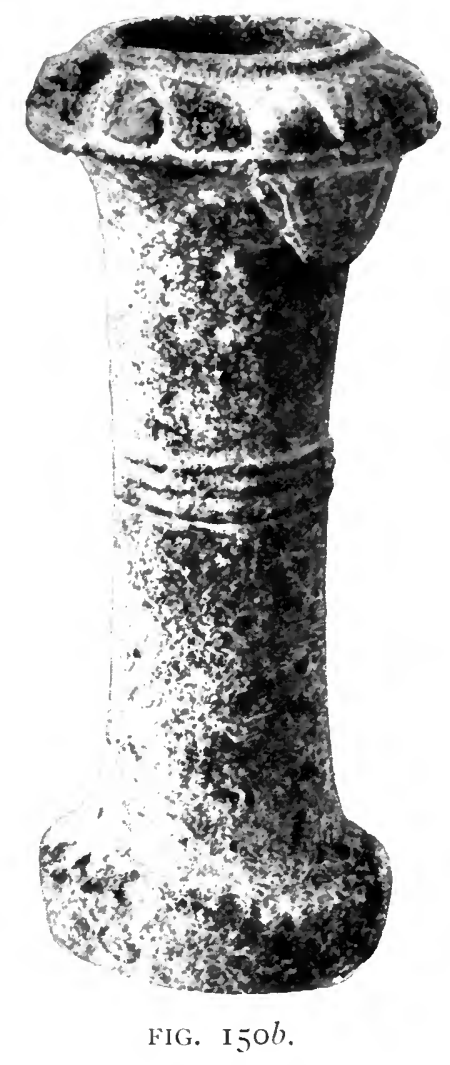

FIG. I $50 b$.

LARGE LAMPS HOLDING ABOVE A IITRE OF OIL.

thrown on the origins of Minoan civilisation. Italy has the honour of having begun Cretan exploration twenty years ago, through the agency of Professor Halbherr of the University of Rome, but we are only at the beginning of this great revolutionary movement in historic study, and we ought not to be satisfied until Italy has investigated the regions of Libya and Cyrenaica and 
made excavations in Tripoli, presumably the cradle of Mediterranean culture. ${ }^{\mathrm{I}}$

Another proof that oil was stored in great abundance is that when the conflagration took place at Knossos the walls of the fourth magazine, where large oil vessels were found, were completely calcined like the walls of an oven.

Olives were used as food in Minoan times, as is proved by the quantity of olive-stones found in the Mycenæan palaces. Tsountas saw a vase at Tiryns full of stones, probably the remains of olives in brine. Olive leaves are painted on Mycenæan vases, and it is easy to recognise olive branches in the decoration of the frescoes.

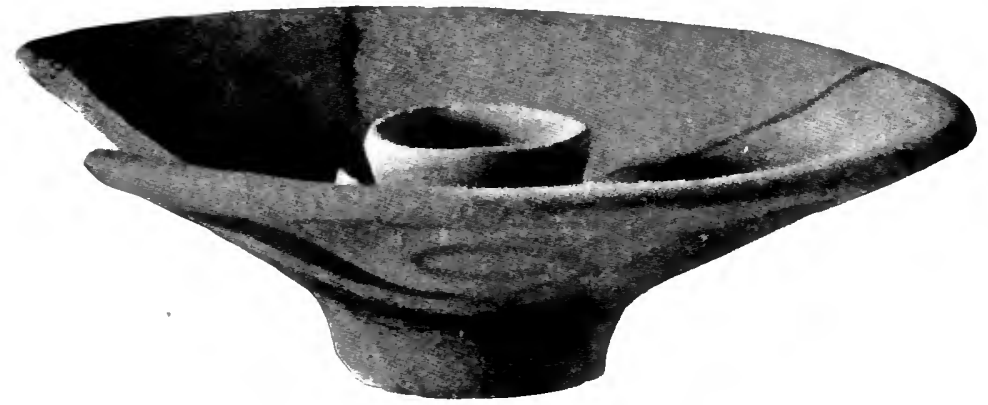

FIG. I5I.-TERRACOTTA CANDLESTICK, WITH SOCKET FOR THE CANDLE, FOCND AT KNOSSOS BY DR. EYANS.

A clay candlestick with wide bottom, just like those used to-day, was found by Dr. Evans at Knossos 2 (Fig. I 5 I). The lower part is decorated with spirals, and the sides are so thin that we may suppose a wax candle was used. I have before me photographs of jugs exactly like those we use to-day to hold water for washing, and a whole series of pots and stewpans, which, though made I000 years before Homer, are the same in form as the utensils of a modern kitchen.

I The following Italian archæologists, in addition to those I have already mentioned, have made explorations in Crete or published works on its ancient remains : Mariani, Taramelli, De Sanctis, Paribeni, and Gerola.

2 "Knossos Excavations," 1902. 


\section{$\mathrm{XI}$.}

After the extinction of Mycenæan civilisation invaders descended on Attica from the rich and fertile countries of Macedonia and Thessaly. At the time of Homer the Hellenes were divided into independent cities, which, according to poetic tradition, were leagued together to make war on Troy.

We do not know how complete was the ruin of Mycenæan civilisation, but we are not justified in supposing that it disappeared without record or trace simply because its environment was different from that of Homeric times. The poems of

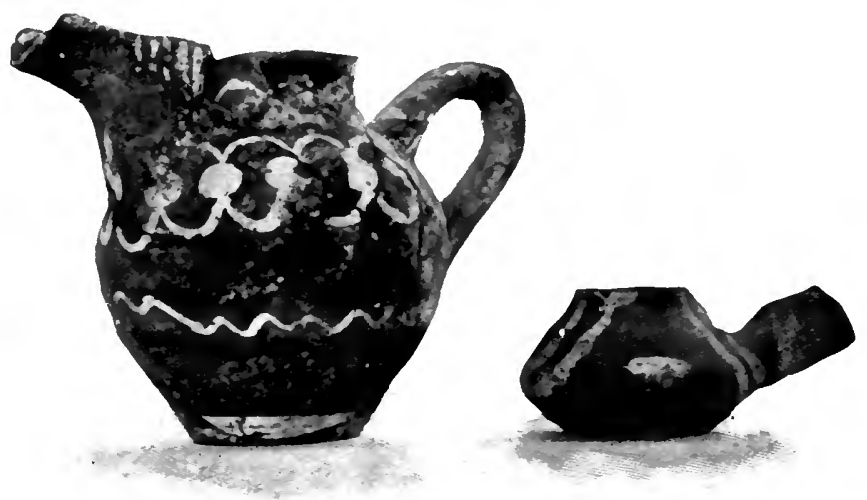

FIG. I52.-PRE-MYCENAAN PAINTED JUG, FOUND AT PHÆSTOS.

Homer contain fables in superabundance and so often substitute myth for history that we must consider them a product of the imagination. The marvellous has the upper hand. The adventures of the heroes of the Round Table are interwoven with stories of fairies, magicians, enchanted grottos, and monsters, the epic of Homeric days was made for the same kind of audience. We find - to take only books ix. and x. of the Odyssey-the Island of Circe, the urn of Æolus, the cave of Polyphemus.

The palaces of Crete do not mark the culminating point of Mycenæan civilisation, which still flourished in the islands of the Ægean and of Greece after the palaces of Phæstos and Knossos 
had been destroyed. Such historical problems can be solved only by archæology, and our gains on this field have been so great that we may almost hope for a ray of light on the Doric Invasion. Dr. Pernier found this year at Prinià an archaic stele showing a gigantic figure of a Greek warrior, with greaves and round shield. Probably this is one of the Doric invaders. In small proportions (according to the Oriental manner) a suppliant figure, dressed in Mycenæan fashion, stands before him. 


\section{CHAPTER XVI}

THE most ancient theatres known to us at present are those 1 of Phæstos and Knossos, and they are important monuments of the history of music and tragedy. Formerly the history of dramatic art began with the year 534 B.c., when Peisistratus gave a representation of the first tragedy in Athens. This was one of the most celebrated epochs of literature. Now that Crete has been excavated, the history of the theatre can begin two thousand years before Peisistratus.

The theatre of Phæstos, discovered by the Italian Archæological Mission, consists of a well-paved court, with a flight of ten steps 25 metres in length on the west, sloping up the hill, and behind it a wall made of large rectangular blocks of limestone.

I give a photograph of the excavations as they first came to light, previous to the restorations (Fig. I 53).

In order that the superficies of the wall which stands behind the last steps should not be too monotonous, four light projections or ridges were made, which provide a little relief. The floor is paved with large stones, and a causeway of larger limestone blocks runs in an oblique direction from the palace, whose entrance is to the right of Fig. I 53, and crosses the area diagonally at a height of $20 \mathrm{~cm}$. On arriving at the flight of steps it is prolonged above them forming a flight of higher stairs, I metre wide, leading to the upper tiers. In the theatre of Knossos we shall 
see a special tribune for the king's court ; here the strip of pavement crossing the area, together with the elevated steps, are all that is specially provided for the prince. On the right hand a great staircase leads to the upper court from which spectators could view the performance.

The Kamáres vases found on the level of the area inform us as to the age of the theatre of Phæstos. It must be referred to a period +500 years earlier than the present time, i.e., to the first period of the middle Minoan age. ${ }^{1}$ The Egyptians had no theatre. This is a construction characteristic of Mediterranean civilisation.

Vitruvius 2 in his "Architecture," where he gives the rules for building a theatre, says that the voice causes an impulse of the air which moves in infinite circles, like the ripples on the surface of a lake caused by the fall of a stone. In order not to obstruct this circular motion of the sound, the seats ought to have the shape of an arc. The Cretan theatres have not the circular form, and this was to be expected, for there is no circular construction in any of the Minoan palaces.

\section{II.}

In 1903 Dr. Evans discovered at Knossos another theatre of Minoan date, but rather later and differently shaped. There is a flight of eighteen steps (seen to the left of Fig. I 54). Another flight of six steps is visible on the right. Into the angle was built a square paved bastion, which most probably formed a support for the seats of distinguished spectators. Evans calls it the "Royal Box." The steps below it, where the public sat, are I 6 metres long.

The entrance to the theatre and the causeway, which served as approach, are still in existence.

The photograph (Fig. I 54) was taken after the restorations, and it is easy to see that the form of the theatre is more

I On carefully examining the steps of the theatre I was surprised to find at the angle the threshold of a door which formed a communication between the theatre and the palace.

2 Vitr., "Architectura," v. iii. 


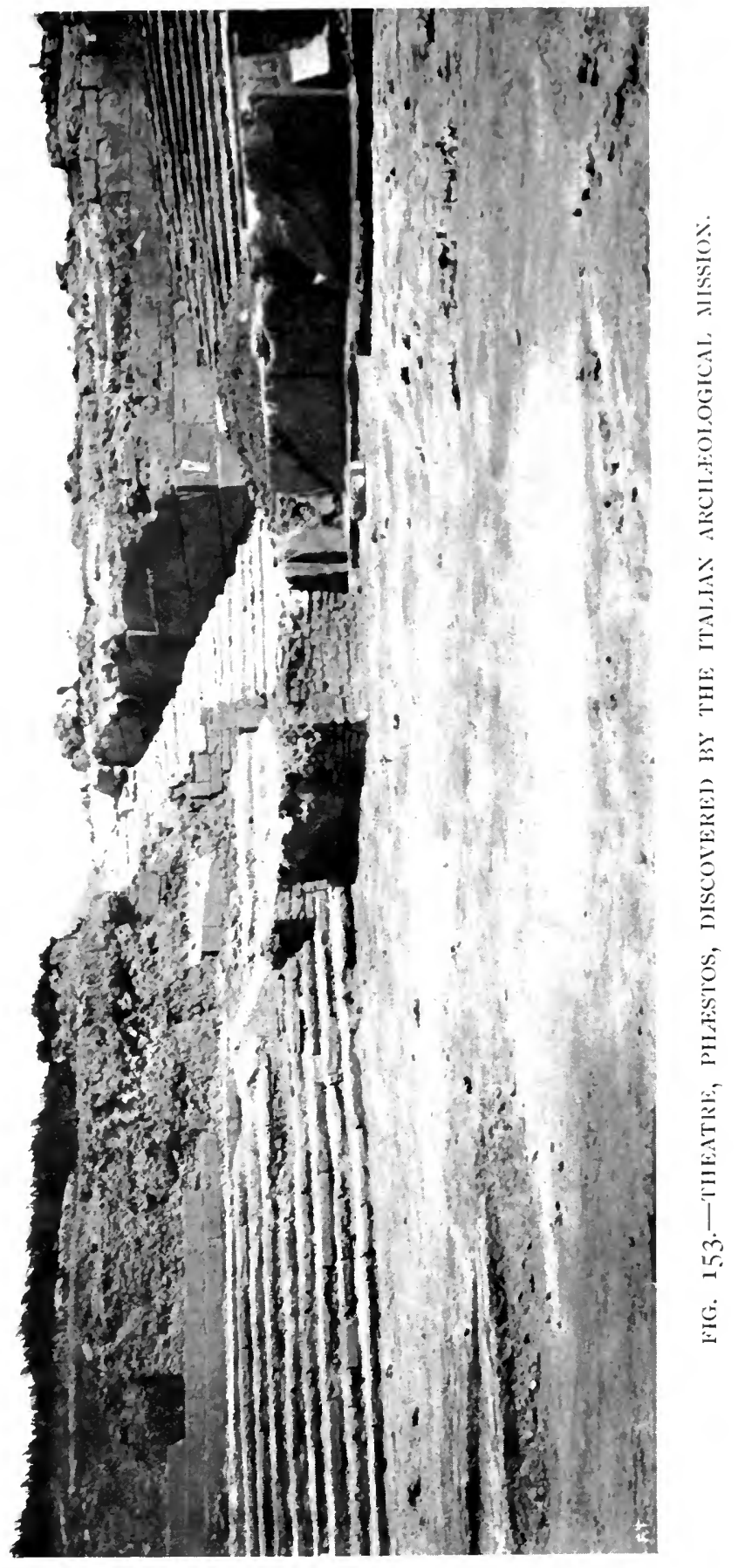



developed than the simple one at Phxstos with its single flight of steps, the two large staircases on the right being of later date. On the smoothly-cemented area gymnastic games took place, such as the bull-fights and dances which we see represented on vases.

When the poet describes the shield of Achilles he was thinking of some such building. A dancing-place like unto that which once in wide Knossos Dædalus wrought for Ariadne of the lovely tresses. ${ }^{1}$

It was formerly difficult to understand why Homer, in describing the shield of Achilles, said that Dædalus made a "dance" for Ariadne. Dædalus was famed for his architecture and sculpture. Homer mentions him once only-as a balletmaster! The theatres we are now studying have solved the riddle.

The word used in the Iliad is choros, and should there be understood to mean "dancing-place," the more because the dance, as described by Homer, contains nothing which could be rationally attributed to Dædalus. 'The legend says that Theseus fell in love with the daughter of Minos during a performance of games. This area, then, must have been the place where Theseus and Ariadne met. I was confirmed in my ideas by seeing a square figure with nine small holes incised on a step of the theatre. Perhaps it was a Mycenæan game. I remembered similar figures cut by idle people on the pavements of the basilicas in the Roman Forum.

III.

Plutarch relates that Theseus, on his voyage from Crete, put in at Delos, and that when he had sacrificed to the god and dedicated the image of Venus which he had received from Ariadne, he danced together with the youths, and that it was said that the youths of Delos still performed this dance, imitating

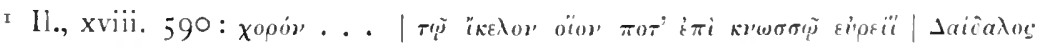

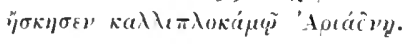


in a rhythmical manner by their turns and changes the windings and openings of the Labyrinth. The custom of dancing the geranos as a memorial of Theseus and of the Cretan Labyrinth continued to Roman times. In the miniature frescoes discovered by Evans, but not yet published, a group of women, elegantly dressed, dance in two rows before the temple.

We cannot compare ancient tragedy with modern because the Hellenes founded their representations on a religious basis. The very name of the chorus is derived from choros, which means a dance, and, as we have seen, dancing formed part of the religious rite. In the seal intaglios women before the altars are shown in attitudes of excitement which may be called orgiastic.

I reproduce a fresco which Evans found in the queen's apartments I (Fig. I 55). The figure is half life-size. It is a girl who must be in the act of dancing, for only rapid rotatory motion could explain the fact that her curls are floating out into the air. Her little short-sleeved jacket is made of yellow stuff, embroidered with a simple geometric design in blue and red. A thin, tight-fitting vest covers her chest. Her right arm is extended.

The Mycenæan ladies are charming. They have not the Greek nose. Their eyes are set slightly oblique, as is seen later in the statues of the Acropolis of Athens, and especially in Etruscan art. This pretty slope of the eye seems to have pleased the Cretan artists. It exaggerates a form of eye which is rare, although it occurs in women even at the present time.

\section{IV.}

When Odysseus goes on an embassy in the name of Agamemnon to bring Achilles to terms, he finds him playing the lyre. Apollo accompanies his own song on the lyre. We do not know what this instrument was like, but we certainly ought now to consider its history as legendary.

Terpander is supposed to have been the inventor of the lyre

$$
\text { ' Evans, “Knossos Excav.," p. 55, I } 902 .
$$




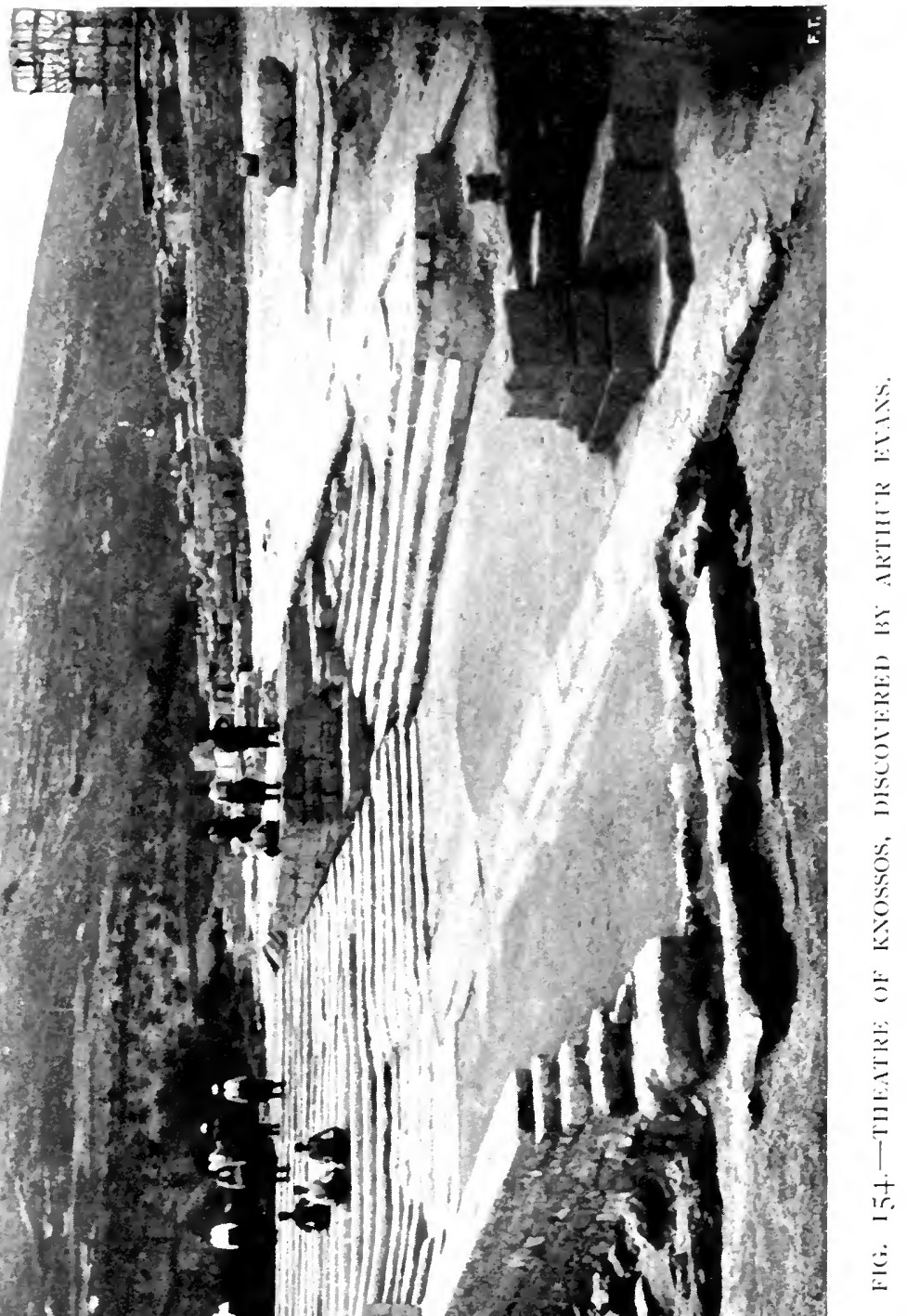



with seven strings, and it is known that in 676 в.c. he was victor in a competition at Sparta. He presented himself with a lyre of seven strings, but it was ruled that he must cut off three for the sake of uniformity with the other competitors. Terpander was celebrated for having introduced new rhythms into poetry, and the reception given by the Spartans to Lesbian music was so enthusiastic that it became proverbial. The records of precedence in this festival read: "First the Lesbian singer, and after him the others." I

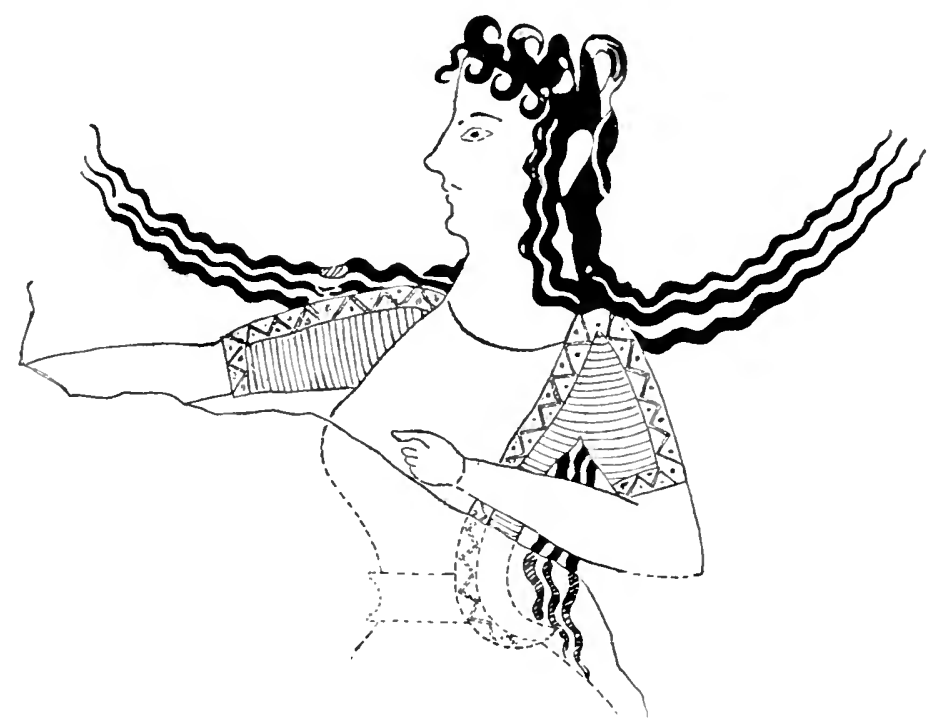

FIG. I55.-FRESCO, KNossOS, DISCOVERE1) BY DR, EVANS.

A thousand years before the time of Terpander the sevenstringed lyre was used in Crete. On the sarcophagus discovered by the Italian Mission (Fig. I 56) (still unpublished) is a complete figure of a man playing the lyre, and beside him is another man playing the double flute (Fig. I 57). Here we see the lyre in its classic form, which afterwards became the national instrument of the Hellenes. The player, though male, wears a long robe, as was probably the custom in religious functions.

I Chrisothemis of Crete was Terpander's master. 
Another lyre with seven strings was found in a fresco in the villa at Hagia Triada. A man is playing, and he holds it higher than his head. As in the lyre of the sarcophagus, the supports of the top bar rest on the curved necks of two swans. ${ }^{\text {I }}$

It is not possible to suppose that the memory of the Mycenæan lyre was lost, and therefore the story of Terpander,

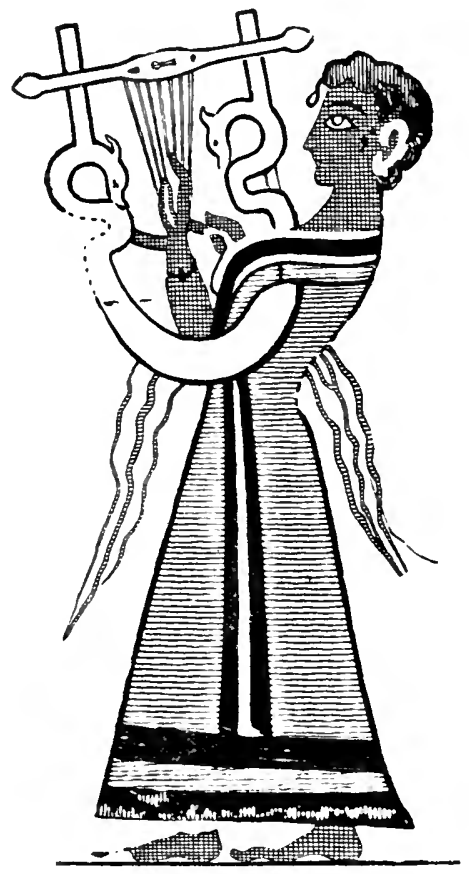

FlG. I56.- MAN PLAYING A LYRE.

Painting on a sarcophagus at Hagia Triada, discovered by the Italian Mission. coming much later, should be considered as a legend.

The Iliad ${ }^{2}$ says that the flute was invented in Crete, but in Homer the simple (avdós) flute is the only one mentioned. We have now, on the sarcophagus of Hagia Triada, not only the double flute, but the most ancient representation of the double flute at present known. The man who plays it has black hair falling on his shoulders, and his hands can be seen running over the perforations. There are two flutes, one a little shorter, for the high sounds, and the other long, forming the bass. Eight perforations are visible, and the hand must cover at least six more, therefore the number of notes was fourteen. A chromatic flute of this kind lent itself to the execution of all the modes required by Greek music.

The small stops added for lowering the sound are represented in Greek and Roman monuments.

Soldiers and bull-fighters have long hair like the man playing

I Schliemann found at Mycenæ a fragment of bone representing a lyre, and three pieces of an ivory flute (p. I 6 , Figs. I $28-130$ ).

2 II., i. 
a lyre. Such was the custom of the Minoan people, unlike that of the Egyptians, who wore their hair short. In the Homeric Epos men and gods are unshorn, and the heroes who take part in Patroklos' funeral games run races with their hair flying in the wind. This usage lasted till the historic age of Greece. When Xerxes sent a spy to find out how many Greeks were assembled at Thermopyla the spy returned and told him they were few in number and were engaged in combing their long hair. In this manner the companions of Leonidas prepared themselves to dispute by force the pass of Thermopylæ. Herodotus I adds

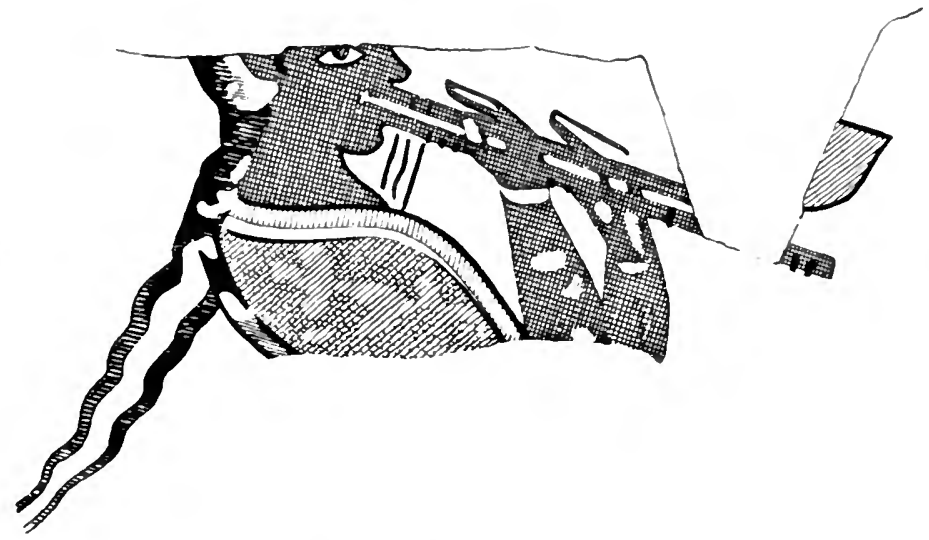

FIG. 157.- MAN PLAYING A DOUBLE FLCTL.

Painting on a sarcophagus at Hagia Triada, discovered by the Italian Mision

that when they are about to pass through a supreme trial the Spartans must, according to usage, first arrange their hair.

\section{V.}

The Eumenides of Æschylus, because of the predominance of choruses, is more comparable to an opera than to a tragedy. Æschylus, being, like Wagner and Boito, both musician and poet, wrote the tunes and dances for his choruses. The "Eumenides" was his last tragedy, and with it ends the trilogy"

s Herod., vii. 209. 
of Orestes. I When the Furies rushed on the stage to punish the crime of Orestes a profound impression was produced, unprecedented in the annals of the theatre.

Composition was simpler, but the musical education of the Greek people was more complete, and the use of a few instruments with voices produced magnificent effects. Gesture added force to the words, and the waves of sound, modulated by passion, formed an irresistible current whose energy equalled that of the modern operatic symphony.

The expressions of joy or grief remain constant because they are caused by involuntary changes in the nerves, which coexist with analogous physiological changes in the human organism; and we may be sure that the music which in early times tried to express these various emotions was not very different from ours. Music derives its expressive value from the modulations produced in the human voice by means of the passions. Any expression not founded on instinct is convention, not real music.

When we hear the hymn to Apollo, discovered in the temple at Delphi, we at once understand how the melic art of ancient Greece corresponds to our modern ideal. The emotional superiority of the Greek theatre must be sought for in the religious sentiment. Worship was re-echoed in ineffable harmonies, aspiration rose to ecstasy, and the passions were exalted beyond the linits of common life.

All the force of Greek music resided in rhythm and melody. Intricacies of tone and successions of harmonies were unknown. Thaletas of Gortyna appears as poet and musician on the borderline between legend and history, and Greece resounded with the pæans of his composition. The chorus originated in these theatres and represents the opinion of spectators on the events of the drama.

Before the time of written law the chorus, accompanying instrumental music with song, avenged crime by execration of the criminal's memory. 'The song was often a reproof to the

$$
\text { I Aschylus afterwards went to Italy. He died at Gela } 456 \text { в.с. }
$$


tyrant, and the response would be like the solenun chant of reason and the proclamation of the moral law. The rights of the people, the power of tradition, resignation to the decree of fate, human virtues-all found in the chant of the chorus their fullest and most lively expression. The instrumental music echoed the words which were still vibating in the soul, and the effect was increased by melody, by rhythm of a few notes, and by the united choric chant.

\section{V'I.}

In the evening, when the workmen had returned to their villages, I sometimes stood on the steps of the theatre to see how the sunset changed the landscape, and to watch the blue tint of the rocks and the rosy hue of the clouds. I tried to preserve in my mind the memory of these calm scenes of glowing colour. I stood motionless and gazed, that I might carry away an indelible impression of the beauty before my eves.

The slope of the hill, which by morning light has the appearance of a uniform wall, is now all furrowed with the tracks of ravines. Those indigo brush-strokes which Leonardo drew on his horizons can be seen winding in the valleys and breaking the contour of the mountains. On the crests of hills little white villages gleam in the twilight. Rays of rosy light filter through the straggling clouds and throw a purple veil over the horizon.

I was near the cradle of drama. I was in front of the most ancient stage. On the slope of this hill the earliest choruses had sung. I thought of the crowd which at this hour many thousand years ago had applauded the performance, and the thought made silence and desolation seem more oppressive.

The majesty of nature and the voices of history resounding in my ears saved me from falling into melancholy, for thus I interpret the circumstance that my mind seemed proof against sadness. Poetic waves and sweet pulsations of the mysterious 
song of Earth and Time seemed to irradiate from the ruins and fill the air with melody.

\section{VII}

Among the objects I found at Phæstos was a fragment of bone, which must have been the mouthpiece of a bagpipe. Two other small bone pipes $10 \mathrm{~cm}$. and $6 \mathrm{~cm}$. in length, of good workmanship, were perhaps two pipes of a shepherd's syrinx. According to Dr. Evans's computation, from the depth at which these instruments were found, they must be about eight thousand years old.

A shepherd in the valley was playing the bagpipe. I showed him the mouthpiece, and he recognised its similarity with the one he had made himself with the thigh-bone of a sheep. The openings on the wooden tube of his bagpipe, which he could stop with his fingers, were similar in design to those of the Neolithic period. He took off the mouthpiece and showed me another that he was just making. Within there were two little tongues of cane giving the same sound, each connected with a larger tube with five square holes fixed in wood. The instrument ended in a funnel like that of a clarinet.

Under the shade of the great plane-tree by the stream, with flocks feeding round us, I invited him to show me how well he could play. He began with some airs, stirring and slow by turns, like the rhythm of the Cretan dances. Then came tunes of folk-songs, and then a mournful cantilena, such as I had heard at night in the mountains. The airs I liked best were dances with a firm and joyous step and a rhythm almost feverish in character. This shepherd must have had the soul of an artist, and I think I have really heard a remnant of primitive music.

Beginning in this humble way, music exercised a powerful influence on human life. Galen used to prescribe for some diseases, playing the flute on the affected organ, thus vouching for his own theory that the passions act on the bodily constitution. When the plague was raging at Sparta the Lacedx- 
monians sent for Thaletas of Gortyna to come and ward off the anger of Apollo by music and song. It was thus that the paan, with rapid rhythm and the Pyrrhic dance passed from Crete to the Continent. When the drooping spirits of the Spartans had been raised, the plague in Sparta ceased.1

$$
\text { t Plut. de Mus., } 9 .
$$




\title{
CHAPTER XVII
}

\author{
MEDITERRANEAN CIVILISATION NOT DERIVED FROM THE \\ INDO-GERMANIC RACE
}

I.

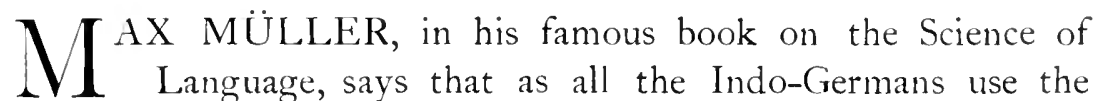
same word for iron, this metal must have been known before they separated. ${ }^{1}$ We are therefore sure that all the monuments of Minoan and Mycenæan date represent a civilisation which was developed unconnected with the Indo-Germans.

The problem of race is apt to become a burning question. Even the most authoritative writers lose their self-control when they are arguing for the primogeniture of their own race. For myself, I do not think the question of race a very important one practically, and if any one asks me what quality there is, physical or intellectual, in the white races, which is the inheritance of one race, and not of all, I answer, "There is no such quality." = Goethe, who began the inquiry into the affinities of species, says: "Was du ererbt von deinen Vatern hast, Erwirb es, um es zu, besitzen!"3

r M. Müller, "V'orlesungen über die Wissenschaft der Sprache," p. 202, Leipzig, 1866.

2 As I have dealt with this argument in several of my works ("L'Educazione fisica," ch. iii.; "La Democrazia nella religione e nella Scienza: La Questione delle razze," ch. iii.), l will not stop now to point out the great infuence on individual development exercised by surroundings and education.

3 Goethe, "Faust," Theil i. 
The evidence brought to light by the excavations in Crete is contrary to the predominant notions of to-day on the subject of the Indo-Germans. Some philologists, to avoid the contradictions which these notions involved in the face of the fact that the Indo-Germans knew metals, tried to push back the division of the primitive race to the last period of the Neolithic Age. For this reason I was much interested in excavating in the deposits left by man before the discovery of metal. The transition from one form of vase to another, the modifications which plastic material underwent, the gradual progress in weapons show the slow development of culture in the Neolithic and Minoan periods. Almost all the new forms of pottery, weapons, or other objects must be referred to external influence.

These rapid transitions are not seen in Crete. Neolithic pottery, black, having scratched designs filled with white chalk, merges into a more elaborate style, the vases take different forms, spiral and geometric patterns begin to appear, and are developed along with coloured pottery, till at last the Kamáres type emerges and the other styles gradually fall into disuse. Colouring becomes more lavish, bizarre motives are used, with timidity at first, afterwards with bold luxuriance. The colour of the ground changes from black to yellowish or red, and then flowers and animals get the upper hand. All this takes place in natural succession without interruption or violent transition. Hence we may be sure that no disturbance like an invasion or conquest by an alien people took place until after the Mycenæan age.

\section{II.}

In 1833 Bopp's study of comparative grammar I showed that Greek and Latin have a certain kinship with German, Gothic, and Slav, and an affinity with Sanscrit and other Asiatic tongues. To account for this kinship Bopp surmises that the peoples who speak these languages had a common origin, and that there was once an original language (Ursprache). He even assumed the

$$
\text { I F. Bopp, "Vergleichende Grammatik," } 1833 .
$$


existence of a people who spoke this language (Urvolk), and to them he gave the name of Aryans, stating that they were the stock from which all nations of Europe and India are derived.

Having laid it down as a principle that language constitutes the common stock of a race and of a people, he arrived at the conclusion that the people who produced the Indo-Germanic civilisation had never seen a lake or the sea, had never heard of fish, and were ignorant of the use of boats and sails, the words denoting these things having no common origin in the IndoGermanic tongues. ${ }^{1}$

Some rebelled against this dogma of the Aryans, but others (and they the majority) went on believing it. Numerous works were printed in which attempts were made to reconstruct the history of the Indo-Germans. ${ }^{2}$

When I read that the Aryan people had not a word for "fingers," 3 I thought this philologic structure could have no solid foundation. The Indo-Germans must have had fingers and hands like ourselves, and they must have given them a name. How is it possible to reconstruct the story of a people's culture according to the words which exist in, or are missing from, the parent language, if such lacunce are to be found?

Schrader supposes that the Indo-Germans, when they divided, were at the same stage of culture as the pile-dwellers. Grave difficulties stand in the way of this hypothesis. The goat, for example, was domesticated by that time, and yet the etymology

I O. Schrader, "Reallexicon der Indogermanischen Alterthumskunde," p. $2+3$.

2 In Italy, Mantegazza said about I $88+$ that the Aryans were a historic myth. The titles alone of the books on this subject would fill a volume. Ripley's work on the races of Europe gives a list of the most important of these works which deal with anthropology, and for the period between $\mathbf{1} 880$ and I 890 only, he names fifty. The publications of philologists are much more numerous. Among recent books on the Aryan question I may mention Salomon Reinach, "L’Origine des Aryens," Paris, I892; Taylor, "L'Origine des Aryens," 1895-1897 : Finot, "Le Préjugé des Races," 1906 ; Sergi, "Arii e Italici," I 898 ; "Gli Arii in Europa e in Asia," 1903.

3 Hirt, "Die Indogermanen," i. p. 23 . 
of its name is not to be found in the Indo-Germanic tongues. The pile-dwellings came later, when Minoan civilisation was in full flower, and they went on existing up to the beginning of the Iron Age, when Minoan civilisation had become extinct.

Language is one of the most fluctuating factors in the culture of a people, and where writing is absent it changes the more rapidly. In the case of some savage tribes it has occurred that a language whose vocabulary had been recorded was unrecognisable after fitty years.

Prehistoric study all tends to show that civilisation is much more ancient than had been formerly supposed. When the mammoth and the reindeer were alive in France, man with his stone weapons had reached a pitch of cultivation sufficient to trace perfect and life-like drawings representing animals whose species is now extinct. It was formerly believed that in the "Reindeer" epoch the people lived entirely by hunting. But incised designs representing ears of corn have been found, and we know that agriculture was practised before the glacial epoch. I

If those races who lived in the earliest Stone Age were husbandmen, it is not possible that a people living in Northern Europe so many thousand years later, who were bearers of civilisation, should be ignorant of agriculture and live entirely by the chase in a nomad and savage state.

\section{III.}

Beloch 2 supposes that the oldest parts of the Iliad were written at a time when iron was unknown. If this is true, it shuts out from Greek literature all Aryan influence.

We cannot study the history of humanity by philology alone, and with no documents except books.

Philologists have regarded language as the whole of man. They have confused race with language and nations with races,

r Bertrand, "L'Art pendant l'age du Renne."

"Rivista di filologia e di istruzione classica," ii., I 8-3. 
whereas these are three completely different things. The modern nationalities of Europe have nothing in common with races, and yet Lapouge ${ }^{I}$ recommends the descendants of the Aryan people to unite for the defence of their race and the purity of their blood. If the Aryan people never existed, this defence would be vain.

The method by which the "Aryan people" was thought out leads to conclusions which cannot be accepted. It is asserted that the Indo-Germans knew copper and iron but did not know the sword, 2 because in the mother-tongue there are words for copper and iron but none for sword. But the fact is that men no sooner became acquainted with copper, bronze, and iron than they made daggers and swords, and the word must have come into existence with the thing.

If we go farther back we find the same deficiency in the words of a primitive language. Names for axe and hatchet 3 are wanting, and we are not even certain that they knew the bow, the arrow, and the quiver. Yet the axe is an implement found among all peoples, from the Stone Age to the Mycenaan period. The priestesses of Theseus and the sacred images are represented with the axe, and I have reproduced a die (in the Museum at Candia) on which is cut a female figure holding two double axes. This figure, whose dress, consisting of an embroidered skirt and an apron, is interesting from its similarity to that worn by the priestess with the serpents, wears on her head a diadem, and we understand from the manner in which the breast is uncovered that the artist wished to represent the nudity customary in sacred rites.

It is strange that the simplest and most primitive type of weapon - the emblem of strength and of divinity in the whole of European civilisation - should not have a name in the language of the Aryan people.4 But this savage people did not know the

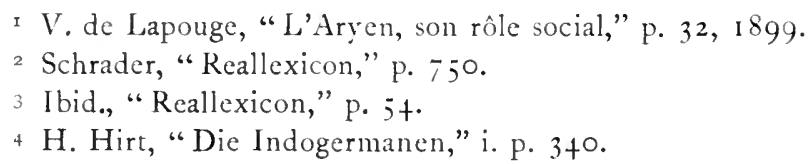


plough, nor the grouping of families to make a village or a city, nor even the house, for all these words are absent in the primitive language. ${ }^{1}$

\section{IV.}

In Sanscrit the word Arya means noble, of good family. As long as people believed in the milestones which marked the route of the Aryan people from India to Europe, this name was accepted without demur. Unfortunately the Indian books are less ancient than was formerly thought. For a long time it had been said that the Vedas were the songs marking the dawn of civilisation, the most ancient book of the Aryans written in the “original human language" (Die Ursprache der Menschheit). Then this view was modified, Sanscrit was called the "eldest sister" of the Indo-Germanic family of languages; now Indian scholars no longer consider the civilisation of the Vedas as very ancient. Bergaigne brings the date of these songs down to about I000 B.c., Pischel and Geldner 2 assert that the Vedas have no Aryan or Indo-Germanic character.

The hypothesis of an Aryan people is contradicted by so many facts that it ought to be abandoned. But a tradition has been formed, and it is very difficult to remove a prejudice supported by schools and treatises on history and sociology.

When it was recognised that the Mediterranean civilisation was not derived from Mesopotamia or India, and that the Pamirs on the tableland of Asia cannot be the cradle of the IndoGermans, philologists began to look for the origins of our civilisation in Europe. As the "cradle" had to be in a central place, whence it would be easy to penetrate to Greece and Italy by the overland route, the steppes of Southern Russia were thought of. In the preceding chapters we have seen irrefragible proofs that European civilisation spread from the Mediterranean towards the North, i.e., just the opposite way. The peoples who

I Thering, “Les Indo-Europeéns avant l'histoire," p. 35, I 895.

? R. Pischel and K. Geldner, "Vedische Studien," i. p. xxii, I 889. 
invaded Europe from Southern Russia never succeeded in imposing their own language on the countries where another was spoken. We physiologists cannot accept this "cradle," because a people so intelligent, so expansive, and so full of penetrative force as to impose its language on all other peoples requires for its sustenance a better nutriment than is afforded by the steppes.

Hippocrates collected arguments fit to combat such hypotheses in the most ancient work on medicine, treating of the influence exercised by environment on the intellectual development of peoples. And besides, history shows that the Scythians, the Huns, the Alans, the Mongols, and all the other barbarian invaders of Europe who came from the southern steppes of Russia, were savage hordes who could destroy, but lacked the psychological qualities necessary for founding civilisation.

Hirt I has written a work in two volumes to prove that the native region of the Indo-Germans is the great north-eastern plain of Germany. Penka 2 maintains that the Aryans are a people of Scandinavian origin. The Finns and the Slavs, according to the results of linguistic archæology, appear to have the best chance of being regarded as the progenitors of European civilisation. Such uncertainty and the useless chase through Asia and Europe to find the cradle of the Aryans is enough to shake all confidence.

When the Finns and the Slavs occupied Europe they were almost savages. They made progress in civilisation through the agency of the peoples into whose midst they had penetrated, and not in consequence of any Aryan superiority. The affinity existing between the Finn and Slav languages and the IndoGermanic tongues forms a sufficient reason for refusing to credit the hypothesis of an original stock, because there is tco great a contrast between the Finns and primitive Slavs, on the one hand and, on the other, the German, Greek, and Latin civilisations.

" H. Hirt, "Die Indogermanen," p. 107, Strassburg, 1905.

z Penka, "Die Herkunft der Arier," Wein, 1886. 
Good sense revolts against a hypothesis whose two most strenuous supporters are at daggers drawn. I If after sixty years of hard work the champions of the "Aryan" cause cannot agree, one begins to suspect that for a study of civilisation among prehistoric peoples comparison of words is not enough.

Hirt would not lay stress on the fact that in the IndoGermanic tongues agricultural names are wanting. He assumes that these expressions have been lost because language is not conservative. ${ }^{2}$ But is is just for that reason that the whole structure raised by comparative philology seems to lack solidity, and Hirt's statement, that the earliest home of the Indo-Germani must be sought in the forests of Europe, seems hardly worth credence. 3

Evolution among animals, plants, and men proceeds better in hot than in cold countries. This is a biological law which it is needless to discuss, and civilisation could not be transmitted in a contrary direction, i.e., from North to South. As to the rate of progress of civilisation, it has been calculated that the state of Northern Europe is about I 500 years behind Southern Europe.t

\section{V.}

The anthropological question is the only one I feel competent to discuss with thoroughness. The other chapters are leaves and flowers, plucked for pleasure on my travels. My proper object was to examine the oldest skeletons and skulls of our race, but I have woven into my book notes on the culture, the home life, and the genius of our ancestors. Dr. Flinders Petrie says that archæology is a late product of knowledge. It has a great attraction for me, and I entered the field of history because I

I O. Schrader, "Reallexicon d. Indogermanischen Alterthumskunde," ., p. 9, $189 \mathrm{I}$.

2 Hirt, op. cit., p. 259.

Ibid., op. cit., p. 259.

+ S. Müller, "Urgeschichte Europas," p. 194, I905. 
feared that the study of skeletons would be useless unless I could find out by the help of excavations what capacity for intellectual production and what skill in handicrafts those men possessed from whom our own civilisation is derived. I began with the Etruscans, then I examined the skeletons of the Romans who lived on the hills of the Eternal City before historic times, and last I came to Crete to make the acquaintance of man in the Bronze Age.

Europe was inhabited in remote ages by men who had the characteristics of the Mediterranean race, a long head and an oval face. These men had reached a very high degree of civilisation in the Stone Age before the invasion of Asiatics with round heads took place. This round-headed people, who have been called " The Alpine race," covered a great wedge-shaped area with its base towards the Black Sea, and extending as far northward as Warsaw, its apex pointing towards Bordeaux. This area includes the Alps and part of Upper Italy. At the present day the Alps and the mountain chains which form continuations of the Alps in Bosnia and Servia are inhabited by round-headed peoples. On the lateral borders of this area there is a gradual mixture of the round-headed with the long-headed peoples. This did not prevent men of the same race from becoming the progenitors of Slavs, Germans, Gauls, Celts, and Latins, all of whom speak different languages.

We see plainly in Switzerland that language is not an important element for discovering the origin of a people. The Alps were inhabited by the Alpine race before German, French, or Italian were spoken. The primitive round-headed people exchanged their ancient language for Italian in the southern region, and began to talk French towards Gaul and German towards Germany.

There is no doubt that men of the same race can speak different languages, just as men of different races can speak the same language. 
V'1.

We cannot affirm with scientific exactitude that the Alpine stock came from Asia, but the characteristics of the head make it probable that they did. Stature and hair also correspond to those of the Asiatic race. The Germans are that part of the primitive Mediterranean stock which occupied all the north of Europe during the Stone Age. Those who went farthest north became fair-haired and taller through the infuence of climate, retaining the long head.

An examination of skulls and bones would be out of place here. The task of excavating and measuring skeletons of men of the Bronze Age was somewhat melancholy. I shall only say enough to give an idea of the scene of my work in Crete and of how I passed long and fatiguing days in and through anthropological study.

Minoan skeletons have become very friable, partly through the corrosion of ages and partly because of the sandy nature of the soil, easily permeated by rain. The water is continually soaking past the bones, and helps to eat them away. In some tombs I only found teeth. Some of the bones fell into dust when touched, and many of the skulls had to be soaked with a solution of gum in alcohol that they might be made solid enough to examine. To move them, they were first rolled in strips of paper and then covered with a layer of plaster, forming large balls, which could be handied without fear of breakage.

In this manner I studied twenty-nine skulls of the Bronze Age, ${ }^{\mathrm{I}}$ and examined many bones preserved intact. The most ancient of these skulls were found at Koumasa, near Gortyna, by Dr. Xanthoudides. Four adjoining tombs, three being domed and

I My thanks are due to Dr. Hazzidaki, director of the Museum in Candia, to Professor Bosanquet and Mr. Dawkins for the help they gave me in my studies. I shall publish later a special work on this subject. Here, I only refer to the objects found. 
one square, belong to the third period of the first Minoan age, and of these I published the weapons, the female idols, and the crockery in Fig. 132. Hundreds of corpses had been buried in each tomb, and the fragments of their bones made a stratum half a metre thick. Mr. Bosanquet (formerly director of the British School of Archæology at Athens) gave me some skulls which he had found at Palaikastro. I Adding my skulls to those studied previously by Duckworth, ${ }^{2}$ we may say that the Cretan skulls of the Bronze Age are better known than the Etruscan ; 3 and this was an important step for anthropology, for they are the skulls of the generations who founded Mediterranean civilisation.

\section{VII}

The Mycenæan people were smaller than the Cretans of co-day, and not so tall as average Italians. In stature they resembled the Sardinians, the Sicilians, and other inhabitants of the southern provinces, who are well known to be smaller than northern Italians.

I will now explain how I made these measurements. Ephor Xanthoudides allowed me to keep for study this larnax (Fig. I 58 ), which he found, covered by two great slabs of terracotta, at Artsa.4 The two vases of Mycenæan style were inside, with the skeleton. The small cup was in the position where it appears in the photograph. In order to fit the corpse into so short a casket it was necessary to bend it. The head and trunk were laid flat, and the legs were doubled up at the knees. It was an ancient custom in Italy to place corpses in a squatting posture instead of extended.

"Bosanquet, "Excavations at Palaikastro," Annual of the British Schoor at Athens, vol. viii., I90I-2.

2 Duckworth measured 64 male skulls and 23 female (British Association, 1893).

3 A. Mosso, "Crani Etruschi," Memorie R. Accaamia delle scienze di Torino, 1906.

4 Length $1 \cdot 1 ; \mathrm{m}$., width $0{ }^{\circ} 6 \mathrm{~m}$. 
The skull is fine and well developed, with cephalic index $77^{\circ} 2$. Where the head and knees touched the sides of the larnax a white efflorescence is to be seen. The vertebral column and the tuberosities of the pelvis also left marks. By means of these marks I could easily find the length of the corpse, which must have been $1.60 \mathrm{~m}$. An intact tibia, $3+\mathrm{c}$. long, corresponds (in tables of proportion) to a height of $\mathrm{I} \cdot 6 \mathrm{I} \mathrm{m}$.

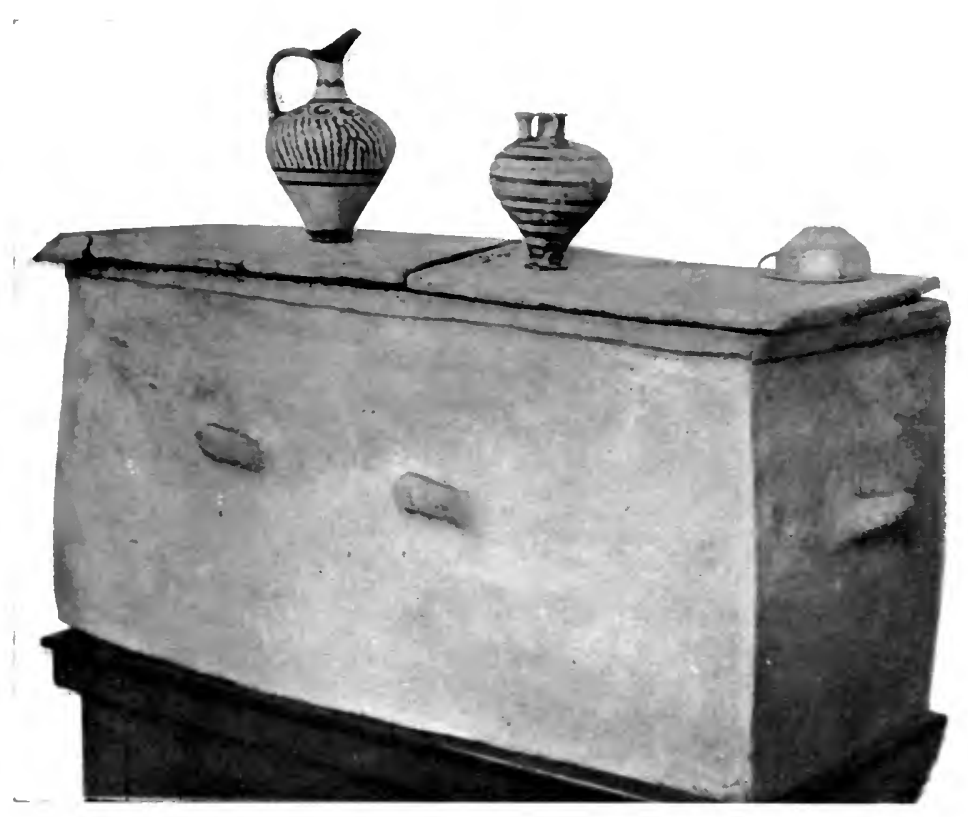

FIG. 158.-LARNAX CONTANING A SKELETON, DISCONERED HY THE EPHOR XANTHOLIHIES AT ARTSA.

in a male. The person was, therefore, below the average in height.

I made other measurements of stature on bones which I found in the necropolis of Phæstos and the tombs of Palaikastro. I handled altogether eight thigh bones and two complete tibia. The calculations give a stature between $\mathrm{I} \cdot 58 \mathrm{~m}$. and $\mathrm{I} \cdot 63 \mathrm{~m}$. Most of the skulls are dolichocephalic and similar to those of the Mediterranean race. 


\section{VIII.}

Last year I found at Camarina, near a wood, I where Professor Orsi had been digging, a large number of larnakes like Figs. I 58 , 159. They looked like terracotta trunks spread about on the fields, and are called so by the peasants. In Homer larnax means a chest to hold linen and other garments.

The primitive rite of burial was to place the corpse seated, with the back leaning against a wall and the knees drawn up to the chin. This being the custom, it is easy to understand that a coffer made a suitable burial casket.

Chests made for funeral use may be distinguished by the fact that the bottom is pierced. But some of the larnakes used for burials are not pierced at the bottom. Such similarity in mode of sepulture between Sicily and Crete proves the relationship between the Mycenæan civilisation and Italy. ${ }^{2}$ Fig. I 59 shows how the larnakes are found. In the slope of the hill is a small corridor leading to a chamber cut in the sandy soil, and in this the larnakes were placed.3 From our examination of skulls and bones we conclude that during the period of about two thousand years intervening between the first skulls of Koumasa and the last of Phæstos the structure of the skeleton did not change. Throughout the gradual growth of civilisation in the Minoan and Mycenæan epochs the human type remained identical. The people were low of stature, with a long shaped skull, black hair, and brown skin, as we see them represented on the frescoes. 'They lack the characteristics of the hypothetical "Indo-German" race, and yet none the less they are the ancestors of that stock which has revolutionised the world by means of intuitive reason and wsthetic feeling.

The thin, straight nose proves that this people does not belong

"Orsi, "Camarina," Monumenti Antichi, R. Acc. Lincei, vol. ix. p. $2+1$.

" Tita moderna degli Italiani," xii : "Le Selve."

3 Savignoni, "Scavi e scoperte nella necropoli di Phastos," Mon. Antichi, R. Acc. dei Lincei, vol. xiv. p. 502 . 


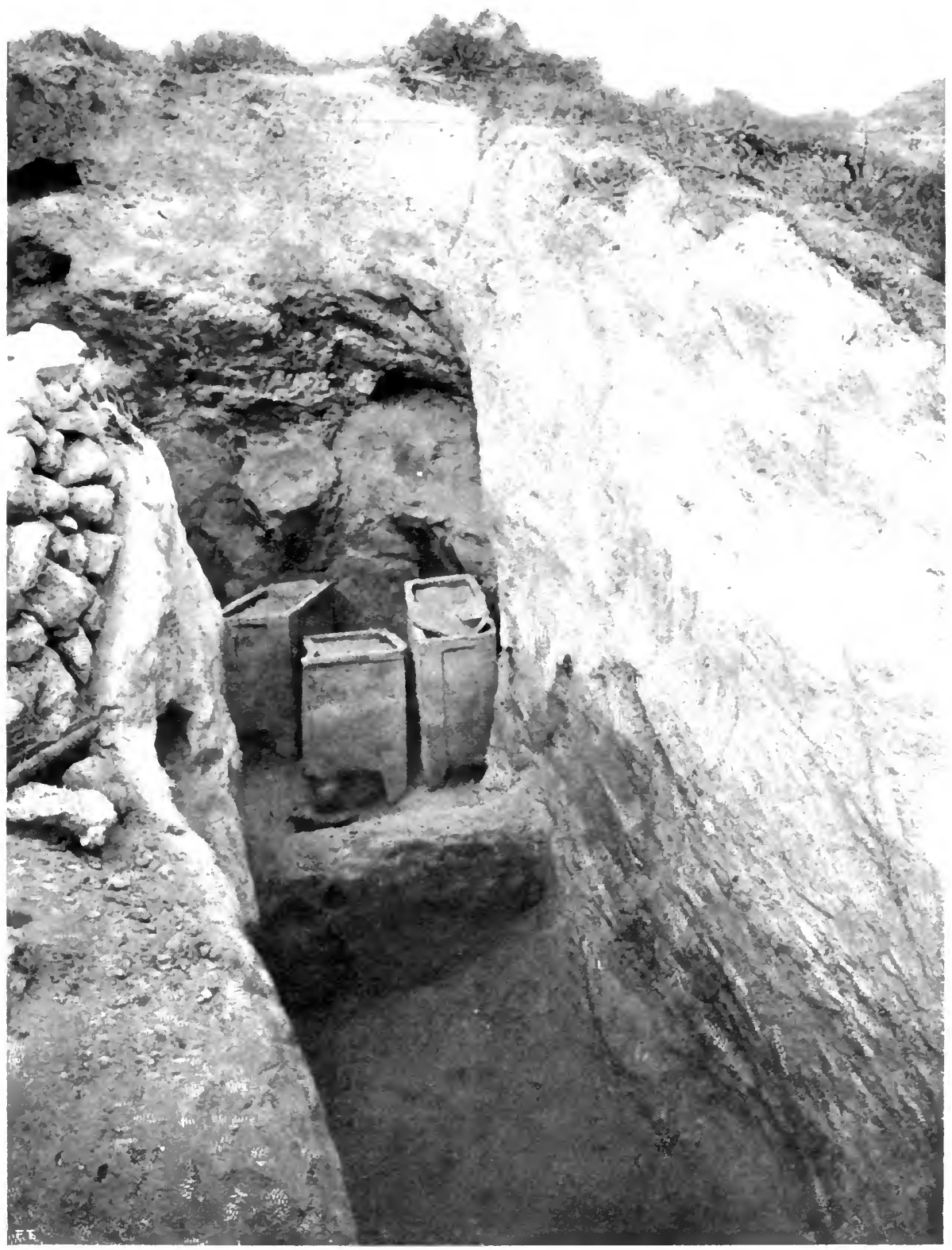

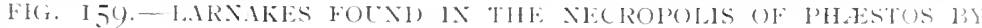

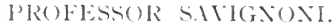



to the Semitic race. The aquiline re-curved nose, characteristic of the Pharaohs, does not appear in any painting or sculpture. The fine black flowing wavy tresses seen on Mycenaan men and women are the prerogative of the Mediterranean race. In these skeletons the aperture of the nose is narrow, a point in which they differ from the negro race. All these peculiarities correspond to those assigned by Sergi to the Mediterranean race, which lived also on the northern shores of Africa.

IX.

This people had reached a high degree of physical excellence. The ancients knew this, and now excavations have thrown a vivid light on the bodily vigour of the Minoan youth. I

The rhyton of Hagia Triada would alone be enough to show what strength and combative instinct belonged to the primitive Mediterranean race. The athletic contests of youths are represented in the lower tiers, and of men in the upper. The youths' heads are uncovered. The men wear a helmet with a horse-hair plume falling down to their shoulders, and they have shoes on their feet.

Fig. I 60 shows us the martial attitude of one of these boxers. The outline of the body is given in dotted lines in order to concentrate attention on the cestus, with which the arms are provided. These were leather gauntlets covering the arm beyond the elbow, padded over the fist, and confined at the wrist by a leather strap. The cestus, which occurs on Greek and Roman statues, is derived from this primitive glove with its flap of leather to cover the knuckles.

The attitude of attack in the right arm and defence in the left are the same as in modern boxing. The youths fight with their bare fists and also by kicking, as in France. These are the

I Pausanias (V. II 9) says that Klymenus came from Crete fifty years after the Deluge, in the times of Deucalion, and celebrated the Olympic Games.

Aristotle ("Politica," ch. vii.) says that the constitution of Sparta, and the Spartan methods for the education of youth, were taken from Crete. 
most ancient representations of "English" and "French" boxing. The exercise is a violent one, and always has been from the beginning. Hence in the Iliad Epeus says he will break his adversary's bones. ${ }^{\text {I }}$

Pugilism flourished in classical Greece and formed part of the Olympic Games. The Latins learned boxing from the Etruscans, for the civilisation of Magna Græcia had faded before the power of Rome arose.

\section{$\mathrm{X}$}

Customs, religion, art, and the structure of the body are more certain guides to the study of a people than their vocabulary and linguistic palæontology.

The excavations in Crete have shown us a Bronze Age so advanced in culture that it becomes impossible to accept the dictum that European civilisation derives from the Indo-Germans. It was Mycenæan culture which originated and developed civilised life in Europe. ${ }^{2}$

It is impossible to suppose that a people who had a civilising influence in the south of Europe or in the north could have lived in a savage state until the Iron Age, because we know that the Mycenæans held lordship over the Mediterranean before the discovery of iron. Minoan culture had lasted several thousand years and had made brilliant advance in art and industry before iron was known; it sank and died of old age when the metal of modern life appeared.

Geographical botany informs us that northern plants had ancestors in southern countries. The spread of vegetation has taken place from the basin of the Mediterranean towards the centre of Europe, and not in the other direction, because southern

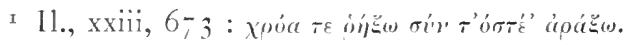

2 When these sheets were in the press Dr. Mackenzie brought out the second part of his "Middle Minoan Pottery of Knossos" (The Fournal of Hellcnic Studics, vol. xxri., I 906, p. $2+3$ ), and touches incidentally on this question. He says that the racial movement which resulted in the Ageo-Mycenæan civilisation was a pre-Aryan one from the south, and that therefore the islands became centres of racial development. 
plants have more power of penetration and they adapt themselves to cold more easily than northern plants bear heat and drought. Besides spontaneous diffusion, man carried domestic plants with him in his migrations, and this vegetable emigration (studied by Hehn) progresses from the Mediterranean towards Central Europe.

Max Müller altered his views on the subject of the Aryans,

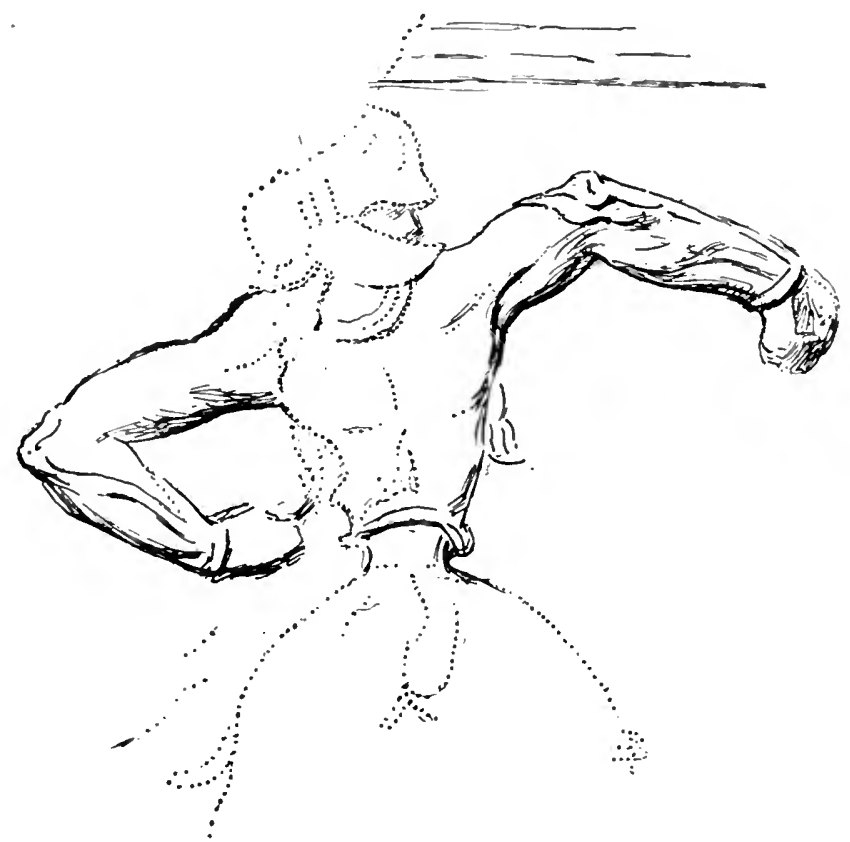

FIG. I6O.-BOXER WTH THE CESTLS ON THE RHYTOY, FROM HAGIA TRIADA.

and latterly used the term "Aryan" not for blood, bones, hair, or skull, but solely for language. This simplifies the problem, but it remains true that the Mediterranean civilisation ran its course without help from the Aryans.

There is no trace of the horse in the Neolithic period of Crete nor in the early Minoan period. Now philologists tell us that the Indo-Germans knew the horse before they divided to form different nations, and in the Indo-Germanic tongues the word 
"ekwos" means "horse." I Dr. Evans 2 found a seal with a record of a horse, possibly the first that ever came to Crete. The perspective is faulty, but evidently the design is a horse being carried along on a barge. Maspero observes that the horse is not represented on the monuments of ancient dynasties, and that it is of later introduction than the time of the shepherd-kings. This seal, belonging to the second period of the late Minoan age, may be dated I 600 years before our era. Since the horse did not exist in Crete at the time when the earliest palaces were founded, we may be sure that Minoan civilisation, parent of Hellenic culture, developed without participation by the Indo-Germans.

I Hirt, "Die Indogermanen."

2. Anmul of British School at Athens, xi. I 3, 1904-1905. 


\section{NDE X}

Ach fans, I8t, 20;

Alabaster, $48,66,68,80-83,127-8$; seats, 63, 8I ; slabs, 120, 128, 259

Alphabet, $73,9^{8}$

Alpine race, 332-3

Apollo, I00; statue of, 99 ; temple of, at Gortyna, 99

Architecture, I57; Cretan, 61, 8I ; Egyptian, 45, 6 I

Arrow heads, bronze, 188

Art, 247,262, 263; decadence, 267;

Egyptian art, 169, 263; representations of animal life, $2 ; 6$

Aryans, 20+, 279, 326, 3+I

Astracasvesto, 20, +2

Astragali, 34, 88

Axe: double axe, I92, $19^{8}$; stone, 25 ; rotive axes, 198,201

Bath at Knossos, 6+; Phrstos, 66 ; ruins of Roman, $\mathbf{I}_{7} 7$; tub, 6 ;

Basilica, 99, I I 2

Beans, peas, and lentils, $+3,155,29$ I

Bechive, If

Belvedere at Hagia Triada, 87

Bethel, I92

Beverages : infusions, 299 ; recipe, 289 ; wine, 289

Bologna, Calf Gate, I 78 ; Marzabotto, I 19

Botany : horse-chestnut, +1 ; flowers, $90,9+, 100,10+, 107-8,193$,
$200,209,255,277$; spreading of plants, $34^{\circ}$

Boxer vase, 2 I I , 339

Bronze, 232, 240, 298; arrow heads, I 88 ; cooking-pots, I $51,297,299$; daggers, 22-; figures, 69, I96, 227 ; objects, 90 ; sickles, $15+$, I67; tools, I 6 ; weapons, I 86-8

Bucchero vases, 25, 27 I

Building, $77,80, \mathrm{I} 4^{8}, \mathrm{I} 57, \mathrm{I} 64$

Bull-grappling, 2II ; fresco, 2I6,

$2 \mathrm{I} 9$; scals, $2 \mathrm{I}+$; on vase, 2 II, 223

Burial customs, I $87,33+, 336$

Candlestick, 306

Carpenter's tomb, $1+6$; tools, $1+5$

Carrier pigeons, 286

Cave of Dicta, $20 \mathrm{I}$; of Eileithyia, 277 ; of Ida, +I, 201 ; Kamares, $+\mathrm{I}$

Chapel or bath (:), 69

Charms : eyes of saints, 83 ; gold fish, 292 ; heart, 88 ; against malaria, 200

Checks and plaids, I 36

Chests (or Cists), I2\%; chests for funeral use, 336 ; lead lined, It+ ; stone chests, $2-3$

Chronology, 18, I19, I $30,156,264$

Church of S. George, $70,83,208$; of S. 'Titus, 93

Cock not found in Homer, 28 ;

Colours, $4^{8}, 5+, 82$, yo, $139,1+2$, 2 I $8,2+3,262$ 
Cookery in Crete, 288 ; in Homer, 288,295

Cooking utensils, 1 52, 296, 301, 306

Copper: belts, $23 \mathrm{I}$; daggers, 227 249,271 ; ingots of, 80,245 ; knives, 227 ; mines, $24^{6}$

Corn, 29I

Corsairs, 89

Court of Knossos, I 20-I ; West Court, I I6; Phastos, 22

Cow-baiting at Viterbo, 214

Cretan hegemony, 58, 89, I59; Socialism, I6I ; workmen, I 45

Cretans on tomb of Rekhmara, 245

Cross of marble, 275 ; gold, 275; porcelain, 275

Crystal goblet, $15^{8}$

Cultus objects, 29, 260, 273, 275

Cup-bearer fresco, $2+5$

Dance: Cretan dance, $\mathbf{1} 70,28 \mathbf{2}$; Geranos at Delos, 313; girl dancing, $3 \mathrm{I} 4$; religious dance, 276,3 I 3

Decimal system, I 88

Descent in female line, 280

Distaff, 153

Door, $45,61,88$; fastenings, $1 ; 6$; hinges, $4^{8}$; scorings, $t^{8}$

Double axe, I98, 20I ; moulds for, I 99

Doves, 257, 282; on columns, 284 ; date of, 286 ; on gold leaf figures, 272 ; in group, 282 ; on Zakros cup, 255

Dress, classical, I 32 ; of Cretans, 76 , I 32, 245, 275, 339 ; of Egyptians, I 39 ; Ex voto, I 36, I39; of gymnasts, 2 I 7 ; of pricstess, 137 , 328 ; of "snake goddess," 274

Excavation, I8, 21, 26, 34, 53, I I 3 , $201,270,305$
Eyes of saints, 83

Fibulate, I I 9

Figs, 1 97, 290

Figures of animals, I96, 250-1 ; bronze, 69 ; femalc idols, 26, I90, 269, $27 \mathrm{I}$; with doves, 282 ; or gold leaf, 272, 283; of ivory, 219 ; marble, $248,27 \mathrm{I}$; of priestess, 1 37, 275; shells, 257 ; of "snake goddess," 30, 274; stucco, 2 I 9 ; terracotta, $136,250,282$; votive figures, 136,250

Fireplace at Phæstos, 293

Fish, figures of, 257 ; flying fish, 257 ; as food, 292

Flints, $t^{8}$; arrow heads, 188

Food in Crete, 290, 293 ; in Homer, 289,292

Foot, shape of, 233

Footgear, 226 ; boots, 22\%, 238 ; shoes and gaiters, 227, 232, 237 , $2+5$

Frescoes, bull, 11 6 ; bull-grappling, 2 I3, 238; cup-bearer, 245; dolphins, I 23 ; Female gymnasts, 217 ; flowers, 87,263 ; girl dancing, 3 I 4 ; men with asses' heads, I 89 ; mullet, 292 ; procession, I1 6 , 239, 275; temple, I 93 ; at Tiryns, 219 ; women at Knossos, I 33

Furnace for pottery, $1+6$

Furniture, I 55, I 56 ; decoration of, +3 ; seats, $1+1$; work table, $1+2$

Gaiters, 226

Games, 75, 3 I 3

Goddess, Aphrodite, 278 ; not Astarte, 280, 286 ; Eileithyia, 277; Rhea, 202, 273; "snake goddess," 274

Gold, cross, 275 ; cups from Vaphio, 223 ; diadems, 188 ; fish, 292; 
heart, 88, 2fir; leaves, Ito; masks, I 88 ; necklaces, $8+$; objects from Mycenx, I88; ornaments, $87,18-, 283$; parements, 240 ; pendant., 88, $24^{8}$; plates, $t^{2}$; scales, 153

Gortyna, city of, 92, $9^{8}$; laws of, $9+$ Gournia, 2;2; bull from, 252, 26;

Grinders, $i^{6}$

Grindstones, 291

Gymnasts, 211,224

Gypsum, 6+1 I I 5, 193

Hagia Triade, 77 ; houses, $14^{8}$; sarcophagus, 290 ; seats, 81 ; sewers, 80 ; villa, 69 ; windows, $8 \mathbf{~}$

Hagii Deka, 92, 108

Hairdressing, I $35,24+, 3$ I 8

Heroon at Gortyna, I 00

Homer untrustworthy, 28;

Horns, 1 94, $215,2,6$

Horse in Crete, $215,3+1$; in Mycenx, 189, 26\%; sacrifice of, I 89 ; on scal, $189,3+2$

Houses, Cretan, $70,108,1+8,15 \mathrm{I}$; Egyptian, +7 ; at Hagia Triada, I f $^{8}$; of Manoli Iliaki at Hagii Deka, Ios ; at Knossos, $14^{8}$; porcelain plicpues, $I_{+} \delta$; Roman 83

Hut floor, I 52, $2+3$; urn, I +9 . 150

Inscriptions at Gortyna, 94, $9^{8}$; of Magna Mater, 30 ; at Palaikastro, $20 \mathrm{I}$; on tomb of Rekhmara, $2+4$

Intaglio, 75,158

Iron, $26,158,32+$

Ivory, casket inlaid with ivory, $29^{8}$; figures, $222,23^{8}$; mirror handle, 283 ; seal, $2+9,28+$

$\mathrm{JARS}, 20,53,124,155$

Jugs, +3, 306
Kamares vases, $+1,+8,53,255,325$

Kasseles, I 27

Kepptiu on tomb of Rekhmara, 2 f $^{6}$

Key, 156

Kitchen, 293 ; utensils, 152, 296301

Knossos, I I 2 ; age of deposits, I 8 , I 9, 310; bath, 64; dancing floor, 313 ; date, II 9 ; destruction of palaces, $16_{3}$; entrance, 115 ; excavations, 17,113 ; frescoes, I 16, 123, 1 33, 239; houses, 1 4 ; magazines, $12+16+$; parements, 113 ; restoration by Dr. Evans, I22; sacred pillars, I92 ; sanctuary, $6+193$; seats, $1 ; 6,163$; sewers, I23; staircase, I2I ; theatre, 115,310; walls, 157, I 78

LABIRINTH, I 99, 3 It

Lake dwelling, , I 6, 29 I

Lamps, 36, 8 I, 302-t

Landscape, 56, 91, 93, 94, 104, 112, I $85,29 \mathrm{I}, 32 \mathrm{I}$

Language, 325,332

Larnax, 26; ; at Hagia 'Triada, 262; from Artsa, $33+$; at Camarina, $33^{6}$

Latrine at Knossos, I 23

Laws of Gortyna, $9+$

Lebes, $9^{8}, 151,297$

Light wells, I 23

Magazives at Knossos, $12 t$; at Phastos, $21,4^{8}, 5^{8}$

Magnetite, 6, 26; analysis of, 29

Marcus Aurelius, tablet to, 10.3

Marriage of heiress, $9+$; consanguineous, 97

Masons' marks, 62

Matriarchy, 280

Meals in common, 58,162

Mediterrancan race, 279, 334, 336, $339, \quad 34^{\circ}$ 
Messari, $19,+5$

Metals, 328 ; bronze, 240 ; copper ingots, 80, 245; copper weapons, 2-I ; gold, 84,240 ; silver, 232 , $2+9,27 \mathrm{I} ; \operatorname{tin}, 23 \mathrm{I}$

Millstones, 29I

Monastery and church of S. George, 208; tombs, 209

Moulds for casting double axes, $19^{8}$; for faïence figures, 256 ; figures, 30

Murex, I +3

Music, 314, 320-2; bag-pipes, 322 ; flute, 317 ; lyre, $31+317$; opera, 319 ; sistrum, 168 ; syrinx, 322

Mycenæ, 173 ; destruction of, $18 ;$; gold ornaments from, 187 ; Lion Gate, I77 ; tombs, 174 ; weapons, I 86

Neolithic stratum, 25 ; term, I 9

Niches in wall of rooms (dulapi), +3, ${ }_{4} 6$

Nose, types of, 233,336

Numerals, $7 \mathbf{I}$

O1L, 302 ; jars, $124, \quad 155,306$; lamps, 302

Olives, 306 ; olive press, $123,30+$; tree, 104, 200, 302

Oxen, 302 ; breeds of, 216 ; bronze, I 96

Palaces, 43 ; destruction of, I63-4; Homeric, 55; of Knossos, 115 ; at Phastos, 19, 45 ; restored portion of, at $\mathrm{K}$ nossos, 122

Pavements of gold, 240 ; of limestone, 22; marble, 243; mud floors, 243 ; neolithic, 243 ; Phæstos, 63 ; preservation of, 239 ; at Tiryns, $2+3$
Pestilence, malaria, 200 ; plague, $322 ;$ typhus antiquorum, 183

Phastos, 19, 45; bath, 66 ; excavations, 20, 26, 36 ; magazines, $2 \mathrm{I}$, $4^{8}$; palace, 47,164 ; private apartment, 63 ; ruins, $19,+5,164$; steps, +6 ; theatre, 19, 309, 310

Plan of ancient cities, 116 ; of the Palace of Knossos, I I 2 ; of private apartment at Phæstos, 63

Pile dwellings, I 16, 291, 327

Pillar worship, I92, I 93

Polecat, 28 ;

Port of Candia, 277 ; Hagia Triada, 77

Potter's shop, 90, I 24

Purple dye, I +2

ReLigion in Crete, 66, 196, 203, 270,273 ; in Homer, $20 ;$; women in, 269

Repoussé work: cornice, 43 ; gold cups from Vaphio, 22.3

Rhyton, from Hagia 'Triada, 339

Road, 1 I 3

Ruins, I03, I73, 208; imminent destruction of, 67; of Roman baths, 47 ; basilica, I 12 ; of Roman theatre, 93

Runnel for water, I I

Sacred stones, 29, I9I; black stone, I 91

Sacred trees, 197, 200

Saffron, 139

Sanctuary at Knossos, 64, 190, 193, 273 ; Phæstos, 66

Sandals, 226, 239

Sarcophagus at Hagia Triada, 290, $3 \mathrm{I} 7$

Scales of gold, 153

Script, Cretan, 72, 162, 252 
Sculpture frieze, 179; stelai, I79, 233,308 ; triglyph, 61 ; Victory of the Acropolis, 239

Sca, 204, 258; power, 89, 160, $16+$

Scals, $7+, 81,171,197,216,237$, $2+9,258,292,3+2$; of ()ueen 'Ty, 87

Seats, $+8,61,81,94,121,1+1,163$, $2 \mathrm{I} T$

Sewers at Hagia 'I'riada, 80 ; Knossos, 123

Shells, 259, 27, ; coloured, 250 , 262, 275; porcelain, 257, 260

Shoes, 227, 239 ; Cretan, 238, 245; Egyptian, $2 q^{6}$; heeled shoes, $23+$

Shovels for hot charcoal, 300

Sicily, I 9, 243, 278, 286, 336

Sickle, 154,167

Skulls, 17, 249, 333, 335

Slaves, I 63

Socialism in Crete, $16 \mathbf{I}$

Staircase, 65, 66, 8 I , I 2 I

Standard of exchange, $9^{8}$

Statue of Apollo at Gortyna, I00; ready-made statues, 98 ; decapitation of, 103 ; of Satornilo, 108

Stature of Mediterrancan race, 334 , 336

Steatopygy, 269

Stelai, 179, 233, 308

Steps, $46,70,3$ ro; in Rome, 77

Stone arrow heads, 188 ; axes, 25 ; idols, 19I ; implements, +3; lamps, 81 ; pestle and mortar, 36 ; slab, 90; vases, 18,188 , $24^{8}$; weapons, 22, 25, 188

Stucco, 82 ; figures, 221

Syrinx, $19^{8}$

TABlets, memorial, 103,201 ; terracotta, $71,162,252$

Temple, batylic, 193; Egyptian, $4^{6}$; at Eryx, 278; procession hetore, 19t; temples as lanks, 128

'Terracotta animals, $250,26-$; hath tub, 65 ; bull, 252; cups, +3, I 5 I ; figures, 188,229 ; jugs, +3 ; reels, 153 ; tablets, $71,162,252$; votive figures, 136, $2+9$; wild goat, 190

Theatre, 310; at Gortyna, 93; at Knossos, II5, 310 ; at Phastos, 19, 309 ; Roman, 93

'Throne of Minos, I 2 I

T'omb of Carpenter at Knossos, $\mathrm{I}+6$; Etruscan, I93; of lsopata, 17t; at Koumasa, 270, 333 ; of $\mathrm{My}$ cenx, $17+$; of Rekhmara, $2+4$; at Remedello, 227; Tholos, at Hagia Triada, $2+9$

Tools, I +5 ; anvil, 158; polisher, I $; 8$

Torches, 302

Triglyph, 6 I

\section{$V_{\text {APHIO }}$ cups, 223}

Tases from Abydos, 18, 1;6; alabaster, 124 ; amphorx, 33, I24, 147 ; Arretine, 193 ; basket decoration, 25 ; bronze, 30,140 , 187; bull's head, 217, 252; bucchero, 25,271; clay reliefs on, 58 ; coloured, $36,+1,43,255$; conical, $213,2+5$; dating by, 130 ; decadent style, 266 ; gold leaf on steatite vases, 76,213 ; with gold foot and neck, 257; in Greek house, 33 ; Harvester, 166; hydrix, 33, 245; Kamares, $4^{1}, 4^{8}, 53,255$; libation, 36 , $255,260,265$; lily design, 182 ; linear design, 182 ; with net and murex, $1+3$; polypus, $193,26+$; soldier, 76,227 ; spiral design, 30,182 ; stcatite, $76,166,19+$, 211,271 ; stone, $18,2+9,271$; 
writing on, 155; from Zakros, Weights, I53; loom weights, I53 $255,28+$

Well, I 53

Votive figures, $136,201,2+9$; of

Windows, $8 \mathrm{I}, \mathrm{I}+9$

animals, $196,2+9,267$; diseases, $250 ;$ dresses, 138 ; of women, I 36

Wood in building, $56,8 \mathbf{1}, \mathbf{1}+8$

Women, dress of, 75, 132, 313 ; position of, $20 \%, 280$; priestesses, 276 ; in religion, 269,276 ; Cretan, type of, 133,313

WaLls, 30, 80, 157; coloured, $14^{8}$;

Worship of female deities, 270, 279; double, 12+; at Gorytna, 92 ; of the Great Mother, 273; Venus Knossos, 178 ; at Mycenæ, 174 , not Phenician, 280, 286 $1-8$

Water supply, I I 3, I 16 ; pipes, IIt

Weapons, 249, 33t; daggers, I86, $27 \mathrm{I} ;$ swords, 186

XOANA, 2־2 

$\therefore$ 
GETTY CENTER LIBRARY 
